ROBERTA BENITO DIAS

\title{
CONTRIBUIÇÃO DO JUIZ E DAS PARTES NA INSTRUÇÃO PROBATÓRIA
}

\author{
DisSERTAÇ̃̃o - MESTRAdO
}

ORIENTAdOR: Professor TITUlaR RogéRIo LAURIA TUCCI

ORIENTADOR "AD HOC": Professor TITUlar José Rogério CRUZ E TuCCI

FACULDADE DE DIREITO DA USP

SÃO PAULO

2013 
ROBERTA BENITO DIAS

\title{
CONTRIBUIÇÃO DO JUIZ E DAS PARTES NA INSTRUÇÃO PROBATÓRIA
}

\author{
Dissertação apresentada como exigência parcial à \\ obtenção do título de Mestre em Direito, no âmbito do \\ Programa de Pós-Graduação da Faculdade de Direito \\ da Universidade de São Paulo, sob orientação do Prof. \\ Titular Rogério Lauria Tucci e orientação “Ad Hoc" do \\ Professor Titular José Rogério Cruz e Tucci
}

FACULDADE DE DIREITO DA USP

SÃO PAULO

2013 


\section{BANCA EXAMINADORA:}

Orientador:

Professor Titular Rogério Lauria Tucci

Professor Titular José Rogério Cruz e Tucci (orientador "Ad Hoc")

Professor Arguidor:

Professor Arguidor: 


\section{AGRADECIMENTOS}

Ao término desta longa jornada, há muito que agradecer a todos aqueles que, direta ou indiretamente, dela fizeram parte.

Aos meus orientadores ROGÉRIO LAURIA TUCCI e JOSÉ ROGÉRIO CRUZ E TUCCI, agradeço pela oportunidade, pela confiança em mim depositada e pelas seguras e valiosas lições transmitidas ao longo de minha orientação.

Aos professores do Departamento de Direito Processual da Faculdade de Direito da USP, em especial aos professores JOSÉ ROGÉRIO CRUZ E TUCCI, LUIZ CARLOS DE AZEVEDO (in memoriam), CÂNDIDO RANGEL DINAMARCO, JOSÉ ROBERTO DOS SANTOS BEDAQUE, ANTONIO CARLOS MARCATO, FLÁVIO LUIZ YARSHELL, PAULO HENRIQUE LUCON e ORESTE NESTOR DE SOUZA LASPRO, agradeço pela dedicação com que ministraram suas aulas durante o Curso de Pós-Graduação e pelos inestimáveis ensinamentos que certamente levarei para toda a vida.

Aos meus sócios e amigos de RODRIGUES BARBOSA, MAC DOWELL DE FIGUEIREDO, GASPARIAN ADVOGADOS, agradeço pela compreensão, pelo incentivo e, especialmente, por tornarem possível o sonho de uma advocacia ética e de alto nível. A vocês todo o meu reconhecimento e o meu carinho.

Ao amigo RODRIGO BENEVIDES DE CARVALHO, meu primeiro incentivador nesta caminhada, agradeço pelos conselhos e pela torcida de sempre.

Aos meus queridos amigos e familiares, agradeço a compreensão por minhas inúmeras ausências e também por, ainda que sem consciência disso, amenizarem as dificuldades desse período.

Aos meus pais, por serem o que são, me fazerem o que sou, e por sonharem junto comigo cada um de meus sonhos.

Ao RICARDO, meu marido, por me acompanhar, me incentivar e me fazer acreditar que tudo daria certo. Percorrer este caminho ao meu lado, logo em nossos primeiros anos de casados, foi sem dúvida uma verdadeira e inesquecível prova de amor.

Enfim, a DEUS, por tornar tudo isso possível. 


\section{RESUMO}

O presente estudo, partindo da premissa de que o processo, assim, como o próprio direito, sofre intensa influência dos valores sociais e das determinantes históricas, políticas e culturais da sociedade em que se insere, tem por escopo analisar a influência das concepções instrumentalista e publicista, do robustecimento de seu conteúdo ético e das demais premissas metodológicas do processo civil atual, na denominada "divisão" de trabalho entre juiz e das partes em todo o iter procedimental, e, notadamente, na atividade probatória, de sorte a reconhecer, com fundamento no modelo constitucional do processo civil brasileiro, a existência de autênticos deveres das partes e do juiz em matéria de prova e analisar as consequências jurídicas de sua inobservância.

Palavras-chave: Direito processual civil brasileiro. Conteúdo ético do processo. Instrução probatória. Ônus da prova. Poderes instrutórios do juiz. Dever de colaboração. Consequências. 


\begin{abstract}
This study, working on the premise that procedural law, as well as law itself, suffers intense influence of social values and society's historical, political and cultural determinants in which it operates, has the scope of analyzing the influence of the instrumentalist and publicist conceptions, the toughening of its ethical content and other methodological premises of the current civil procedure in the denominated "division" of labor between judge and parties throughout the procedural path, and notably in the evidentiary activity, so as to recognize, based on the constitutional model of the Brazilian civil procedure, the existence of genuine obligations of the parties and the judge regarding evidentiary matter and analyze the legal consequences of their noncompliance.
\end{abstract}

Keywords: Brazilian civil procedural law. Ethical content of the process. Discovery phase. Burden of proof. Judge's investigative powers. Duty to cooperate. Consequences. 


\section{SUMÁRIO}

\section{PREMISSAS METOdológicas do PROCESSO CIVIL ATUAL E SUA}

INFLUÊNCIA NA CONDUTA DO JUIZ E DAS PARTES NO PROCESSO ...............12

1.1. Fases metodológicas da ciência processual civil: do sincretismo à instrumentalidade ................12

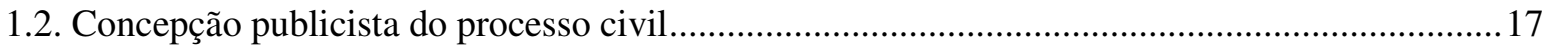

1.3. A ideia do formalismo-valorativo e o denominado "modelo cooperativo de processo" ..............22

1.4. Efetividade da tutela jurisdicional e o fator temporal do processo...............................................2

2.1. Noções preliminares: direito à prova - conceito, objeto e finalidade da prova judiciária.

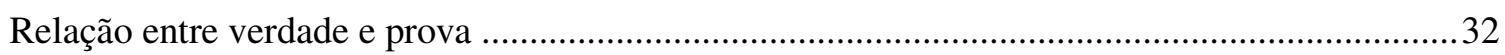

2.2. Posições ativas e passivas assumidas pelas partes e pelo juiz na relação jurídica processual.....41

2.3. Visão tridimensional do denominado "direito à prova" ................................................................... 47

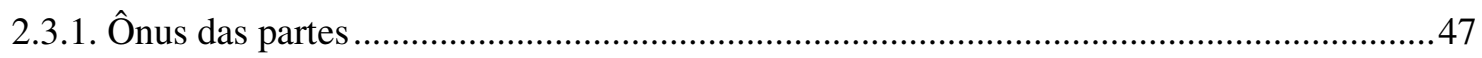

2.3.2. Poder instrutório do juiz e direito (ou poder) probatório das partes ...................................52

2.3.3. Dever de colaboração para a elucidação dos fatos .................................................................58

3. DEVERES DE LEALDADE PROCESSUAL, VERACIDADE, BOA-FÉ E COLABORAÇÃO - O CONTEÚDO ÉTICO DO PROCESSO …....................................65

3.1. Exigência de comportamento probo em juízo: o dever de lealdade processual ...........................65

3.2. Caracterização e extensão do dever de veracidade...................................................................... 70

3.3. Abuso do processo e responsabilidade por improbidade processual.............................................78

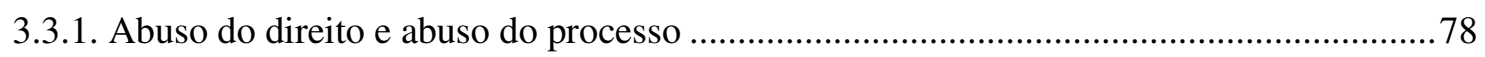

3.3.2. Abuso do processo no ordenamento jurídico brasileiro e a responsabilidade por

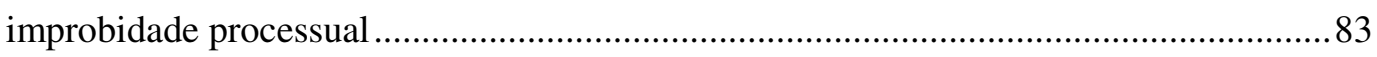

3.4. Aplicação da cláusula geral de boa-fé no processo civil, dever de colaboração e inadmissibilidade do comportamento contraditório - nemo potest verire contra factum

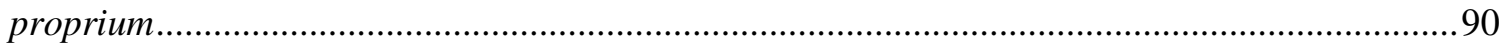

3.5. Dever de colaboração no Projeto do Novo Código de Processo Civil (PLS n. 166/2010)...........96

4. Divisão de trabalho ENTRE JUIZ E PARTES NA ATIVIDAde

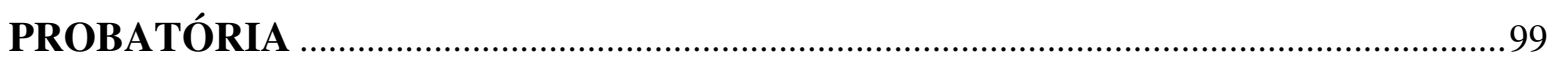

4.1. O papel do juiz e das partes na instrução processual..................................................................99

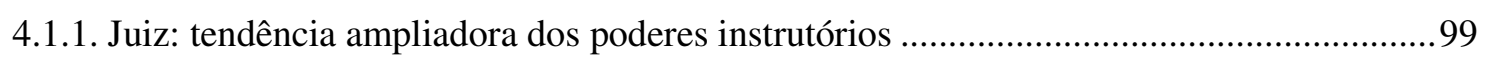

4.1.2. Partes: a abrangência do princípio do contraditório .................................................... 110 


\subsection{MANIFESTAÇÕES DO DEVER DE COLABORAÇÃO NA INSTRUÇÃO

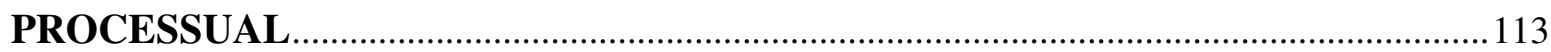

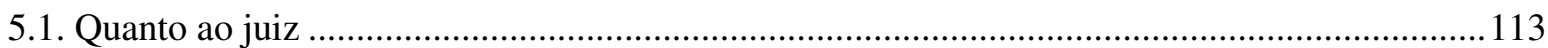

5.1.1. Deveres de esclarecimento, prevenção, consulta e auxílio ............................................114

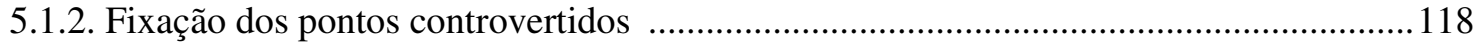

5.1.3. Distribuição do encargo probatório - momento de inversão do ônus da prova ................120

5.1.4. Juízo de admissibilidade da prova e impossibilidade de valoração antecipada de seu resultado

5.1.5. Submissão de toda e qualquer prova ao crivo das partes e outros deveres relacionados à instrução

5.1.6. Limites: fator temporal do processo, natureza dos direitos controvertidos, limites objetivos da lide, tratamento isonômico das partes, responsabilidade do juiz e princípios da legalidade e da motivação das decisões judiciais .......................................132

5.2. Quanto às partes

5.2.1. Deveres de exposição dos fatos conforme a verdade, colaboração no seu esclarecimento e submissão aos poderes instrutórios do juiz

5.2.2. Dever de comparecer em juízo e submeter-se a interrogatório ou depoimento pessoal, submeter-se à inspeção judicial e dar cumprimento às ordens judiciais.

5.2.3 Regras de exclusão

\section{CONSEQUÊNCIAS DA INOBSERVÂNCIA DO DEVER DE COLABORAÇÃO}

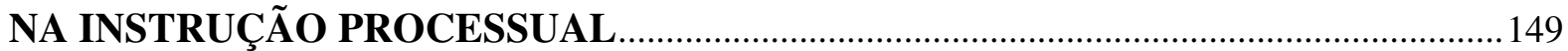

6.1. Consequências processuais: o valor probatório do comportamento processual das partes .......149

6.2. Sanções pecuniárias, medidas de sub-rogação e medidas coercitivas .........................................156

6.3. Responsabilização civil, administrativa e a função social do juiz no processo civil atual .........160 


\section{INTRODUÇÃO}

O processo civil moderno reconhece o direito de ação não somente como o direito de acesso à ordem jurídica, mas sim como o direito de obter uma solução justa ao litígio submetido ao poder jurisdicional do Estado, o que pressupõe o acesso das partes à ampla produção de provas, para que a decisão judicial possa ser prolatada da forma mais aderente possível à realidade.

A ciência processual, por outro lado, já superou há muito a concepção privatista outrora reinante, muito embora ainda se verifique setores da doutrina - especialmente estrangeira - receosos de uma exacerbação indevida do conteúdo publicista do processo, tida como manifestação de um autoritarismo político e de uma ideologia antiliberal.

Nesse sentido, no atual estágio de desenvolvimento do estudo do processo, é incontestável o interesse do Estado na pacificação dos conflitos e na justa composição dos litígios, qualquer que seja a natureza do direito material envolvido, o que tem justificado o reforço dos poderes diretivos do juiz no feito e ressaltado a relevância de sua participação ativa também na fase instrutória do processo, já que o desatendimento do ônus de provar atribuído às partes e a consequente lacuna probatória acarreta consequências negativas não somente aos próprios litigantes, mas também ao interesse público presente no desenvolvimento da atividade jurisdicional.

Nesse cenário, nosso estudo, partindo da premissa de que a disciplina legal do processo, assim ocorre com o próprio direito, sofre intensa influência dos valores sociais e das determinantes históricas, políticas e culturais da sociedade na qual se insere, analisará as três conhecidas fases metodológicas da ciência processual civil - sincretista, autonomista e instrumentalista - e suas principais características, considerando o momento histórico e político em que cada uma delas foi desenvolvida. A partir daí, passará a abordar a recente tendência de um setor da doutrina nacional no sentido de reconhecer, na atualidade, a vigência de um quarto momento metodológico da ciência processual civil, fundado no marco teórico do "formalismo-valorativo" e correspondente a um modelo de processo pautado pelo permanente diálogo judiciário, colaboração e lealdade entre as pessoas que dele participam. 
Independentemente de tratar-se ou não de um "novo" momento metodológico, essa atual concepção do processo civil - decorrente não apenas de uma visão axiológica do fenômeno processual, mas também da compreensão das determinantes constitucionais do sistema jurídico brasileiro - é fruto, como se verá, do desenvolvimento das ideias instrumentalista e publicista e têm raízes também no robustecimento do conteúdo ético do processo.

Essas ideias têm ensejado, por sua vez, notadamente nos últimos anos, uma reavaliação da denominada "divisão de trabalho" entre juiz e partes no processo, com a revisão do papel de cada qual em todo o iter procedimental.

Valoriza-se, assim, o denominado "diálogo judiciário" e pressupõe-se que autor, juiz e réu ocupam no processo posições jurídicas coordenadas, ideia fundada nos próprios objetivos do Estado Democrático de Direito brasileiro - de construir uma sociedade livre, justa e solidária - e que tem como pilares fundamentais a submissão do Estado ao direito e a participação social na sua gestão.

Destaca-se, nesse sentido, o papel do contraditório efetivo, não somente enquanto elemento legitimador da decisão judicial, mas como exigência da própria democracia participativa. Dá-se relevo, por outro lado, ao papel ativo e colaborativo do juiz, enquanto instrumento para a edição de decisões justas e elemento apto à consecução dos escopos jurídico e social da jurisdição.

O reforço da posição jurídica das partes e a dupla posição assumida pelo juiz (paritária no desenvolvimento e assimétrica na decisão) são características marcantes dessa nova concepção do processo civil brasileiro e que se refletem fortemente na condução da atividade probatória, objeto específico de nosso estudo.

Nesse sentido, a instrução processual passa a ser entendida como uma fase de "busca coletiva de esclarecimentos", pautada pela comunhão de trabalho entre partes e juiz, que têm o dever de colaborar e não obstaculizar o esclarecimento dos fatos, a fim de viabilizar a obtenção de um resultado útil e justo do processo (e, ainda, em tempo razoável), relativizando, de certa maneira, a importância do ônus da prova (ao menos sob o prisma subjetivo) e reequacionado a questão da preclusão em matéria de prova.

Nesse ponto, então, após analisarmos o conceito, o objeto e a finalidade da prova judiciária no processo civil atual e as diversas posições jurídicas assumidas pelas partes e pelo juiz na relação jurídica processual, trataremos da prova sob três diferentes aspectos: 
enquanto ônus das partes; como poder instrutório do juiz e direito (ou poder) das partes; e também enquanto projeção do dever de colaboração para a elucidação dos fatos, o que denominamos de visão "tridimensional" do direito à prova.

Na sequência, nosso estudo analisará importantes aspectos relacionados ao conteúdo ético do processo e, notadamente, aos princípios da lealdade, probidade e veracidade, reguladores não somente da conduta das partes, mas de todos aqueles que intervêm no processo.

Serão tratadas questões referentes ao devido processo "leal", à caracterização e extensão do dever de veracidade no processo, à responsabilidade por improbidade processual e às recentes reformas legislativas com o escopo de robustecer a ética no processo, à aplicação da cláusula-geral de boa-fé no processo civil, ao dever de colaboração e à inadmissibilidade do comportamento contraditório (nemo potest venire contra factum proprium) no processo civil.

Partindo, então, do reconhecimento da existência de autênticos deveres do juiz e das partes em matéria de prova, chegaremos ao ponto central da dissertação, com a análise de alguns exemplos colhidos na doutrina, na jurisprudência e nas próprias regras processuais, de manifestações desse dever de colaboração, ou seja, de condutas exigíveis das partes e do juiz no curso da instrução processual e de seus respectivos limites ou regras de exclusão.

Por fim, analisaremos as consequências jurídicas da inobservância desse denominado dever de colaboração das partes e do juiz na instrução processual e as delicadas questões daí decorrentes.

Interessantes e intrigantes questões jurídicas surgirão da análise do tema. Dentre elas, será possível a imposição às partes de medidas coercitivas ou sub-rogatórias em caso de recusa de auxiliarem na descoberta da verdade? Essas medidas podem ser impostas ainda que o ordenamento jurídico estabeleça, para a hipótese, consequência processual específica, qual seja, a presunção de veracidade do fato que se pretendia provar? Pode haver cumulação de medidas de sub-rogação ou coercitivas com a sanção pecuniária por litigância de má-fé nesses casos?

Nesse contexto será tratada, ainda, a relevante e debatida questão do valor probatório do comportamento processual das partes e também as consequências verificáveis quando a negativa de colaboração na instrução advém do órgão jurisdicional. 
O tema, como se vê, é dotado de importância e atualidade - o que é corroborado pela existência de recentes obras doutrinárias a tratar do assunto - e acompanha a tendência científica moderna, no sentido de "revisitar" os institutos processuais (no caso específico: o ônus da prova, poderes instrutórios do juiz, o contraditório, dentre outros), harmonizando sua interpretação aos avanços científicos na matéria. 


\section{PREMISSAS METODOLÓGICAS DO PROCESSO CIVIL ATUAL E SUA INFLUÊNCIA NA CONDUTA DO JUIZ E DAS PARTES NO PROCESSO}

\subsection{Fases metodológicas da ciência processual civil: do sincretismo à instrumentalidade}

O processo, assim como o próprio direito, não é infenso aos valores sociais e às determinantes históricas, políticas e culturais da sociedade na qual se insere, sendo essa a razão pela qual a ciência processual civil experimentou, ao longo dos anos, diversos momentos metodológicos.

A ideia do direito processual como ciência somente passou a ser concebida e aceita pela comunidade jurídica a partir do final do século XIX, o que se atribui, em grande parte, ao legado racionalista do período iluminista ${ }^{1}$. Antes disso, predominava a confusão entre os planos material e processual do ordenamento jurídico.

Esse sincretismo inicial entre o direito material e o processo, existente desde os primórdios do processo civil romano - no qual a ação se confundia com o próprio direito substantivo lesado ${ }^{2}$, fazia com que o processo fosse entendido como mero procedimento para efetivação dos direitos subjetivos (daí a alcunha, hoje rejeitada pela doutrina processual, de "direito adjetivo") ${ }^{3}$. Não havia consciência a respeito da distinção, hoje

\footnotetext{
${ }^{1}$ Nas palavras de Cândido Rangel Dinamarco: "As transformações políticas e sociais havidas na Europa desde o século anterior tinham sido capazes de alterar a fórmula das relações entre o Estado e o indivíduo, com a ruptura de velhas estruturas - e isso foi responsável pelas primeiras preocupações em definir os fenômenos do processo, onde assoma a figura do juiz como agente estatal, a partir de premissas e conceitos antes não revelados à ciência dos estudiosos que se debruçavam sobre o direito judiciário civil (mera procédure)” (in, A instrumentalidade do processo, 13. ed. São Paulo: Malheiros Ed., 2008, p. 17).

${ }^{2} \mathrm{O}$ direito romano não conhecia a distinção entre direito material e direito processual. As fontes de direito (leis, ius civile, editos, etc.) previam um conjunto de ações e não de direitos substantivos. Por isso é que se diz que a ordem jurídica romana consistia num sistema de ações e não num sistema de direitos subjetivos. Consequentemente, a actio concernia apenas a quem tinha razão. Se o pretor ou o juiz privado (no período do ordo iudiciorum privatorum) ou então o princeps ou magistrado (no período da extraordinária cognitio) entendia pelo cabimento da pretensão, concedia a actio, se entendia pelo descabimento, negava-a (actionem denegat).

${ }^{3}$ A respeito, Galeno Lacerda explica que "tão impróprio é definir o arado como adjetivo da terra, o piano como adjetivo da música, quando o processo como adjetivo do direito em função do qual ele atua. Instrumento não constitui qualidade da matéria que modela, mas ente ontologicamente distinto, embora a esta vinculado por um nexo de finalidade." (in, Comentários ao Código de Processo Civil. 7. ed. Rio de Janeiro: Forense, 1998. v. 8, t. 1, p. 23-24).
} 
sedimentada, entre a relação jurídica processual e a relação jurídica material objeto da disputa.

Enfim, o clima privatista preponderava, dando azo à prevalência do princípio dispositivo e à plena disponibilidade das relações jurídico-processuais, consequências do liberalismo político então reinante. A doutrina alude a essa primeira fase do processo civil como "sincretismo", ou "praxismo", período em que predominou a concepção privatista do processo civil.

A partir do final do século XIX, no entanto, o desenvolvimento dos estudos de direito processual levaram à consciência da autonomia não somente da ação, mas de todo o processo.

Conforme aponta a doutrina, essa segunda fase da ciência processual teve início com a famosa polêmica de Windscheid e Müther a respeito do tradicional conceito civilista de ação e sua distinção da actio romana. Aquela, diferentemente desta, não é instituto de direito material, mas processual, não se dirige ao ex adverso, mas sim ao juiz e não tem por objeto o próprio bem da vida almejado, mas sim a tutela jurisdicional.

O desenvolvimento e racionalização dessas ideias levou Oskar Von Bülow a proclamar, em famosa obra lançada em $1868^{6}$, a existência de uma relação jurídica processual entre os sujeitos principais do processo - juiz, autor e réu - que se distinguia da relação de direito material por seu objeto (provimento jurisdicional) e seus pressupostos (pressupostos processuais) ${ }^{7}$.

Passou-se então a conferir tratamento científico ao processo civil, agora dotado de método e objetivos próprios, distintos do direito material subjacente à relação processual. Toda a construção científica do direito processual se deu nessa segunda fase metodológica da ciência processual - denominada de "autonomista" -, quando foram traçadas as grandes

${ }^{4}$ DINAMARCO, Cândido Rangel. Instituições de direito processual civil. 6. ed. São Paulo: Malheiros Ed., 2009. v. 1, p. 261.

${ }^{5}$ MITIDIERO, Daniel. Colaboração no processo civil: pressupostos sociais, lógicos e éticos. São Paulo: Ed. Revista dos Tribunais, 2009. p. 30.

${ }^{6}$ BULOW, Oscar. La teoria de las excepciones procesales y los presupuestos procesales. México, D.F.: Instituto de la Judicatura Federal Biblioteca Felipe Tena Ramírez. Disponível em: $<$ http://www.ijf.cjf.gob.mx/Bibliotecadigital/von_b\%C3\%BClow.asp>.

${ }^{7} \mathrm{~A}$ obra é tida como a "certidão de nascimento do direito processual civil" (DINAMARCO, Cândido Rangel. Instituições de direito processual civil, cit., v. 1, p. 258). Antes dele, no entanto, a compreensão do processo como relação jurídica já havia sido esboçada por Hegel e mais tarde por Bethmann-Holweg, esta última referida por Von Büllow (PONTES DE MIRANDA, Francisco Cavalcanti. Comentários ao Código de Processo Civil. 4 ed. Rio de Janeiro: Forense, 1997. v. 3, p. 435). 
linhas do direito processual $\operatorname{civil}^{8}$, chegando-se ao ponto de maturidade da ciência processual.

Bedaque $^{9}$ destaca, no entanto, que, ultrapassada a grande euforia da fase denominada autonomista, os estudiosos do direito processual civil se depararam com o inaceitável abismo criado entre o processo e o direito material. A comunidade jurídica passou então a tomar consciência de que não obstante a autonomia científica de cada qual, não se justificava a separação estanque entre direito (material) e processo, pois a finalidade precípua das regras de direito processual é, exatamente, garantir que a norma substantiva seja atuada. Também não mais se justificava a insistência nas investigações puramente conceituais, despidas de um endereçamento prático, finalístico.

Essa mudança de mentalidade, segundo Dinamarco ${ }^{10}$, foi observada quando alguns estudiosos, especialmente os italianos Mauro Cappelletti e Vittorio Denti lançaram as bases de um método que privilegia a importância dos resultados da experiência processual na vida dos litigantes, o que "abriu caminho para o realce hoje dado aos escopos sociais e políticos da ordem processual",".

A moderna ciência processual civil, então, passou a voltar sua atenção ao caráter instrumental do processo e à necessidade de assegurar o alcance de seus fins, ou seja, a realização do direito material. Essas ideias, pioreiramente difundidas, no Brasil, por Dinamarco, marcam o terceiro momento metodológico da ciência processual, ainda vigente na atualidade, denominado de "instrumentalista". A esse respeito, Bedaque destaca:

"Trata-se, sem dúvida, de uma nova visão do fenômeno processual,
instrumento cuja utilidade é medida em função dos benefícios que possa
trazer para o titular de um direito protegido pelo ordenamento jurídico
material. A conscientização de que o processo não vale tanto pelo que ele
é, mas fundamentalmente pelos resultados que produz, tem levado

\footnotetext{
8“"Com a obra de Oscar Bulow, e a partir dela, o processo deixa de ser mero procedimento, convertendo-se na abstrata relação jurídica que obedece a pressupostos de existência e validade. A jurisdição assume a condição de poder vocacionado já não mais à tutela dos direitos subjetivos, acometendo-se-lhe a função de realizar o direito objetivo estatal e pacificar a sociedade. A ação deixa de ser compreendida como um apêndice do direito material, passando a representar um direito público subjetivo autônomo de ir a juízo e lograr sentença. Nega-se, portanto, toda a perspectiva metodológica do praxismo: o direito judiciário converte-se em direito processual - passa-se de uma 'procedura', de inspiração privatista, para um 'diritto processualle', de veio publicístico" (MITIDIERO, Daniel. Colaboração no processo civil: pressupostos sociais, lógicos e éticos, cit., p. 34).

${ }^{9}$ BEDAQUE, José Roberto dos Santos. Direito e processo. São Paulo: Malheiros Ed., 1995.

${ }^{10}$ DINAMARCO, Cândido Rangel. Instituições de direito processual civil, cit., v. 1, p. 262.

${ }^{11}$ Sob a perspectiva instrumentalista, o processo civil passou a ser entendido como sistema que tem escopos políticos (afirmação da autoridade do Estado e participação dos atores sociais), jurídicos (concretizar a vontade do direito) e sociais (pacificação social e educação do povo) a alcançar. (DINAMARCO, Cândido Rangel. A instrumentalidade do processo. 13. ed. São Paulo: Malheiros Ed., 2008).
} 
estudiosos a reexaminar os institutos processuais, a fim de sintonizá-los com a nova perspectiva metodológica da ciência." 12

Destaca-se também na fase instrumentalista o aspecto ético do processo e o reconhecimento de sua permeabilidade aos valores vigentes na sociedade e, especialmente, àqueles tutelados pela ordem político-constitucional. Assim, superando a perspectiva puramente técnica, o processo passou a ser visto como um instrumento a serviço do direito material, atento às necessidades políticas e sociais de seu tempo ${ }^{13}$.

Como menciona Grinover ${ }^{14}$, na concepção moderna da ciência processual, como instrumento para a garantia e efetivação de direitos, a visão puramente técnica não pode mais prevalecer, pois a ela se sobrepõem valores éticos de liberdade e justiça.

Com efeito, a perspectiva constitucional do processo, objeto de atenção dos estudiosos nas últimas décadas, veio a contribuir para afastar, de forma definitiva, o processo do plano das construções conceituais e meramente técnicas e inseri-lo na realidade política e social, pois, como se reconhece na atualidade, o processo não é ciência neutra às opções axiológicas do Estado e da sociedade.

Assim, através da perspectiva constitucional, também chamada de "tutela constitucional do processo", os institutos e as normas processuais são interpretados em consonância com os valores consagrados constitucionalmente, tais como a liberdade, a igualdade, a legalidade, a dignidade da pessoa humana, o regime democrático, etc ${ }^{15}$.

Nery Júnior afirma que, no caso brasileiro, a perspectiva constitucional do processo somente passou a ser difundida com maior intensidade recentemente, especialmente em razão da conturbada conjuntura política vivenciada nos últimos anos e dos poucos hiatos de tempo em que o país viveu em Estado de Direito e em regime democrático. Entretanto, a partir de 1988, com a promulgação de nossa Constituição Federal e o restabelecimento do regime democrático, esse estado de coisas se modificou, sendo cada vez maior o

\footnotetext{
${ }^{12}$ BEDAQUE, José Roberto dos Santos. Direito e processo, cit., p. 14.

${ }^{13}$ MITIDIERO, Daniel. Colaboração no processo civil: pressupostos sociais, lógicos e éticos, cit., p. 35.

${ }^{14}$ GRINOVER, Ada Pellegrini. O processo em sua Unidade II. Rio de Janeiro: Forense, 1984. p. XV.

${ }^{15}$ "De forma bem simples e bem direta é possivel (e necessário) concluir no sentido de que é a Constituição Federal o ponto de partida de qualquer reflexão do direito processual civil. A Constituição Federal e o 'modelo constitucional do direito processual civil' dela extraível são o eixo sistemático (consciente) do estudo do direito processual civil. O plano constitucional delimita, impõe, molda, contamina o modo de ser de todo o direito processual civil e de cada um de seus temas e institutos. O plano infraconstitucional do direito processual civil é assim, caracterizado, conformado, pelo que a Constituição impõe acerca da forma de exercício do poder estatal." (BUENO, Cassio Scarpinella. Curso de sistematizado de direito processual civil. 6. ed. rev. atual e ampl. São Paulo: Saraiva, 2012. v. 1, p. 84-85).
} 
número de trabalhos e estudos jurídicos envolvendo a interpretação e aplicação da Constituição Federal, inclusive no que se refere às regras do processo, o que demonstra a tendência brasileira de colocar o direito constitucional em seu verdadeiro e meritório lugar: o de base fundamental para o direito do País ${ }^{16}$.

Esse fenômeno - da permeabilidade do processo aos valores sociais e às opções político-constitucionais - tem também estimulado, em grande medida, as sucessivas ondas renovatórias da legislação processual infraconstitucional, não apenas para adequá-las a alterações promovidas na própria Carta Constitucional (como foi o caso da emblemática Emenda Constitucional no 45/2004), mas também em virtude de nova interpretação dada a determinados institutos, normas e garantias constitucionais, em razão de evolução dos valores ou mesmo mutações sociais.

Scarpinella Bueno, ao tratar dos elementos para a compreensão do que denomina de "fase contemporânea do pensamento do direito processual civil", destaca ainda a concretização dos direitos fundamentais, cuja ênfase é dada pelo constitucionalismo atual, como temática obrigatória à pauta das preocupações da ciência processual ${ }^{17}$.

É justamente nesse contexto que a doutrina processual civil tem se dedicado, nos últimos anos, a revisitar determinados institutos e temas processuais, como é o caso do acesso à justiça, da efetividade da tutela jurisdicional, do tratamento isonômico das partes no âmbito do processo, do conteúdo ético do processo, dentre outros temas relevantes, no intuito de adaptá-los a essa nova perspectiva metodológica do direito processual ${ }^{18}$.

E, no que interessa especificamente ao presente estudo, essa revisão dos institutos e temas processuais também abarca uma nova interpretação a respeito da postura e da

\footnotetext{
${ }^{16}$ NERY JÚNIOR, Nelson. Princípios do processo na Constituição Federal: processo civil, penal e administrativo. 9. ed. rev. e atual. São Paulo: Ed. Revista dos Tribunais, 2009., p. 40.

${ }^{17}$ Segundo Cássio Scarpinella Bueno: “... a temática dos 'direitos fundamentais' não pode ser alheia à pauta de preocupações do pensamento contemporâneo do direito processual civil na exata medida em que seus estudiosos não negam que eles, os direitos fundamentais, integram-se ao ordenamento jurídico por intermédio de princípios jurídicos e, nesta medida, convida, ela própria, a uma renovada reflexão do direito processual civil desde o plano constitucional. É por isto, aliás, que alguns autores vêm-se referindo a um 'direito fundamental à efetividade da jurisdição' $e$, mais amplamente, ao próprio 'direito de ação' como um 'direito fundamental” (in, Curso de sistematizado de direito processual civil, cit., v. 1, p. 97).

${ }^{18}$ Nas palavras de Cândido Rangel Dinamarco: "Um dos grandes serviços que o processualista prestou ao direito e à justiça nas últimas décadas foi a enérgica afirmação do comprometimento axiológico das instituições processuais: ele repensou o significado e a medida da indiferença inicial a que obrigado o juiz, o qual na realidade precisa estar iluminado pela visão dos resultados sócio-econômicos e políticos a que a sua decisão poderá conduzir.” (in, A instrumentalidade do processo, cit., p. 45).
} 
chamada divisão de trabalho ${ }^{19}$ entre o juiz e as partes em todo o iter procedimental e, em especial, no curso da fase instrutória, como se verá adiante.

\subsection{Concepção publicista do processo civil}

A evolução dos estudos do processo também abriu espaço para o progresso da perspectiva publicista do direito processual, com o reconhecimento do interesse do próprio Estado na consecução das finalidades do processo, na medida em que este constitui ferramenta, de natureza pública, para a realização da justiça e obtenção da paz social.

O germe dessa ideia se identifica no reconhecimento da autonomia do processo e da existência de uma relação jurídica entre os sujeitos processuais principais (autor, réu e juiz) que tem natureza jurídica de direito público e que é independente da natureza dos interesses em disputa ${ }^{20}$.

Além disso, a evolução da teoria do Estado levou à consciência dos conceitos de soberania e inevitabilidade do poder estatal ${ }^{21}$, bem como ao desenvolvimento da ideia de que o Estado também deve se submeter à ordem jurídica, como pressuposto de validade de seus atos.

Nesse sentido, abandonou-se a antiga concepção, oriunda o direito romano e da então denominada litis contestatio ${ }^{22}$, de que o processo teria natureza de um contrato (ou

\footnotetext{
${ }^{19}$ A expressão foi cunhada por José Carlos Barbosa Moreira em obra intitulada O problema da divisão de trabalho entre juiz e partes: aspectos terminológicos. In: Temas de direito processual: $4^{\mathrm{a}}$ série. São Paulo: Saraiva, 1989.

${ }^{20}$ BULOW, Oscar. La teoria de las excepciones procesales y los presupuestos procesales, cit.

21 "O poder dominante apresenta duas características básicas: é originário e irresistível. Caracteriza-se como um poder originário porque o Estado Moderno se afirma a si mesmo como o princípio originário dos submetidos. Isto se torna manifesto pelo direito que ele próprio se atribui, de dispor, mediante suas leis, em seu território, de todo o poder de dominação. Ainda que concedendo aos submetidos um relativo poder de independência perante ele, o Estado tem um poder que lhe é próprio e do qual derivam os demais poderes. O poder do Estado é também irresistível, por ser um poder dominante. Dominar significa mandar de um modo incondicionado e poder exercer coação para que se cumpram as ordens dadas. Além desse aspecto, a irresistibilidade se revela na impossibilidade em que se acha o submetido de se subtrair ao poder dominante." (DALLARI, Dalmo de Abreu. Elementos da teoria geral do Estado. 19 ed. atual. São Paulo: Saraiva, 1995. p. 94).

22،... a tendência da doutrina mais moderna converge no sentido de que a litis contestatio redundava num consenso progressivo, a final do procedimento in iure, verificado entre os litigantes quanto ao objeto da fórmula, e que culminava com o decretum do pretor. O escopo primordial da litis contestatio seria, portanto, o de fixar o ponto ou os pontos litigiosos da questão, definindo os lindes da sentença a ser proferida pelo iudex e obrigando os litigantes a respeitá-la." (CRUZ E TUCCI, José Rogério; AZEVEDO, Luiz Carlos de. Lições de história de processo civil romano. 1. ed. 2 tir. São Paulo: Ed. Revista dos Tribunais, 2001. p. 100).
} 
quase-contrato), em que as partes se comprometiam, voluntariamente, a se submeter ao seu resultado $^{23}$, admitindo-se, a partir de então, que a imperatividade da decisão judicial decorre do própria soberania e poder de império do Estado.

Foi na Idade Contemporânea que esses conceitos se aprimoraram, com a radical transformação do modo de regulação do poder político e a institucionalização do Estado de Direito, que tem como conteúdo essencial a supremacia do direito, o reconhecimento dos direitos fundamentais do cidadão - oponíveis ao próprio Estado -, e a soberania e divisão dos poderes estatais ${ }^{24}$. E, no Estado de Direito, a jurisdição constitui manifestação do poder estatal destinada a solucionar de conflitos de interesses dos jurisdicionados, substituindo a vontade dos interessados pela atuação concreta da vontade da lei, o que se dá pela imposição imperativa da decisão judicial ${ }^{25}$.

A moderna doutrina processual reconhece, assim, a natureza pública do processo, em abandono à antiga visão privatista do instituto, o que constitui uma tendência universal, em que pese a existência de vozes na doutrina absolutamente contrárias à denominada publicização do processo civil, associando-a ao afastamento dos direitos individuais e a um denominado autoritarismo processual, decorrente de uma ideologia antiliberal ${ }^{26}$.

${ }^{23 ،}$ “Como, ao tempo do procedimento formulário, assim como nos períodos precedentes, o processo civil romano tinha caráter eminentemente privado, análogo ao de nosso juízo arbitral, que pressupunha a adesão voluntária do demandado como condição de procedibilidade, a litis contestatio desempenhava o papel de uma novação, relativamente à primitiva obrigação, de tal modo que esta obligatio, que dera origem à demanda, desaparecia e o demandado que devia em razão do vínculo obrigacional, a partir daquele momento processual, encontrava-se obrigado em virtude não mais do contrato, e sim da nova relação processual criada pela litis contestatio." (BAPTISTA DA SILVA, Ovídio. Jurisdição e execução na tradição romano-canônica. Rio de Janeiro: Forense, 2007. p. 66).

${ }^{24}$ A esse respeito Norberto Bobbio assevera: "Por Estado de direito entende-se geralmente um Estado em que os poderes públicos são regulados por normas gerais (as leis fundamentais ou constitucionais) e devem ser exercidos no âmbito das leis que o regulam, salvo o direito do cidadão recorrer a um juiz independente para fazer com que seja reconhecido e refutado o abuso e o excesso de poder. (...) Do Estado de Direito em sentido forte, que é aquele próprio da doutrina liberal, são parte integrante todos os mecanismos constitucionais que impedem ou obstaculizam o exercício arbitrário e ilegítimo do poder e impedem ou desencorajam o abuso ou exercício ilegal do poder." (in, BOBBIO, Norberto. Liberalismo e democracia. Tradução Marco Aurelio Nogueira. São Paulo: Brasiliense, 2000. p. 19).

${ }^{25} \mathrm{Com}$ relação à ideia de jurisdição como atividade secundária, em substituição à vontade das partes, teoria formulada por Chiovenda, é de todo pertinente a observação de Cândido Rangel Dinamarco, com arrimo no pensamento de Galeno Lacerda: "Isso só tem sentido quando se cuida de relações jurídicas privadas regidas pela disponibilidade, onde realmente a 'execução e o próprio processo não são senão o segundo dos instrumentos que o ordenamento jurídico predispõe à satisfação do direito objetivo (e o primeiro, mais natural e em geral mais eficiente deles, é constituído por um sistema de pressões sobre a vontade do obrigado, para que ele cumpra por sua própria deliberação o preceito emergente da norma). À medida que o processo civil se afasta da sua origem, mais fácil vai-se tornando a percepção de que pretensões há que somente pela via do processo podem ser satisfeitas. É o caso da pretensão de anular o casamento ou o contrato, ou à exclusão do herdeiro por indignidade..." (in, A instrumentalidade do processo, cit., p. 53-54).

${ }^{26} \mathrm{Na}$ doutrina espanhola, Juan Montero Aroca se destaca como o maior crítico da denominada publicização do processo civil. Veja-se trecho de uma de suas obra: "durante el último siglo, la sociedade ha visto nacer y desarrollarse vários intentos, no ya de hacer predominar lo colectivo sobre lo individual en todos los 
E, no caso brasileiro, essa visão publicista é ainda mais justificada pelo modelo de Estado e as opções políticas por ele adotadas.

Em primeiro lugar, o processo civil brasileiro, por uma opção político-legislativa, diferentemente daquela adotada por países da família romano-germânica, tal como a Itália, não se limita a desempenhar função jurisdicional em matéria civil, sendo aplicável também para a resolução de todo e qualquer conflito jurisdicional relacionado a temas de direito administrativo, tributário, constitucional, etc., matérias, portanto, de direito público. No Brasil, a denominada "jurisdição administrativa" típica de países do sistema europeu, que decide lides envolvendo a Administração e o administrado ou funcionário, é exercida também pelo Poder Judiciário, através do processo civil. Daí porque, no caso brasileiro, tanto menos se justifica a concepção do direito processual como mero apêndice do direito privado.

Além disso, o Estado brasileiro, por expressa disposição constitucional, constitui-se em um Estado Democrático de Direito fundado na dignidade da pessoa humana e que tem, dentre seus objetivos fundamentais, os de promover o bem de todos, garantir o desenvolvimento nacional e construir uma sociedade livre, justa e solidária.

Ou seja, o Estado brasileiro, contrapondo-se à ideia do liberalismo e absenteísmo estatal, adotou o modelo de um Estado Social e Democrático de Direito, e, na linha das Constituições modernas, assumiu a postura de agente do desenvolvimento e da justiça social, garantindo direitos individuais e sociais aos indivíduos e propiciando-lhes

órdenes de la vida, sino de processo ha incidido con claras manifestaciones autoritarias y que en el processo civil se há llamado publicización. Es ya hora de dejar atrás esa estapa y de abrir nuevos caminhos. Si el passado es la publicización y el autoritarismo, en el futuro está la concepción del proceso, também el civil, como garantia." (MONTERO AROCA, Juan. El proceso civil llamado 'social' como instrumento de justicia autoritária. In: MONTERO AROCA, Juan (Coord.). Proceso civil e ideologia: un prefacio, una sentencia, dos cartas y quince ensayos. Valencia: Tirant Lo Blanch, 2006. p. 165). Já na Itália, Franco Cipriani, destaca-se dentre os críticos mais severos da publicização do processo civil e do aumento dos poderes instrutórios do juiz, assim se manifesta: "las repetidas alusiones al hecho de que el proceso es um médio para que las partes (...) colaboren com el juez en la obtención de lo más justo (...) se comprenden en un contexto ideológico que parte de dar como sobrentendido que los ciudadanos no tienem derecho de 'pelear' por lo que crean que es suyo y a hacerlo con todas las armas que les proporciona el ordenamiento jurídico." (CIPRIANI, Franco. El proceso civil italiano entre revisionistas y negacionistas. In: MONTERO AROCA, Juan (Coord.). Proceso civil e ideologia: un prefacio, una sentencia, dos cartas y quince ensayos,cit., p. 59). Em posicionamento contrário Taruffo demonstra que não há correlação entre o aumento dos poderes do juiz e a ideologia antiliberal, autoritária ou totalitária, já que, por um lado, nem todos os regimes políticos autoritários encarnaram de forma incontestável o aumento doss poderes do juiz e, de outro lado, muitos regimes democráticos introduziram relevantes poderes intrsutórios de ofício (cf. TARUFFO, Michele. Poderes probatórios de las partes e del juez en Europa, publicado originalmente em Riv. Tri. Proc. Civ. v. 60, n. 2, 2006). Também no mesmo sentido de Taruffo: BARBOSA MOREIRA, José Carlos. O neoprivatismo no processo civil. In: Saraiva, 1997. p. 87-101. Temas de direito processual: nona série. São Paulo: 
prestações estatais positivas (tais como educação, saúde, previdência, moradia, etc.) para atingimento desses objetivos ${ }^{27}$.

O caráter público do processo, portanto, também decorre naturalmente dos princípios constitucionais consagrados pelo Estado brasileiro.

Essa influência política, por sua vez, é notada no processo civil brasileiro em diversos aspectos. A esse respeito, Dinamarco ${ }^{28}$ assenta que, no direito processual, a preponderância da ordem pública sobre a dos interesses privados em conflito manifesta-se em inúmeros pontos da dogmática, dentre os quais a inafastabilidade do controle jurisdicional, a garantia do juiz natural, a livre investigação das provas, a liberdade de convencimento do juiz e o dever de fundamentar sentenças, a exigência do contraditório efetivo e equilibrado, o dever de lealdade, a repulsa à litigância de má-fé e atos atentatórios à dignidade da justiça (contempt of court), dentre outros. E arremata dizendo que:

"Esses e outros sinais tornam sem dúvida que o sistema processual da
atualidade é voltado à tutela de uma ordem superior de princípios e
valores que se situam fora e acima do âmbito estrito dos interesses
controvertidos entre as partes (ordem pública) e que, em seu conjunto,
dirigem-se ao bem comum, como objetivo síntese do Estado moderno." 29

A ideia central da visão publicista, hoje predominante, é a de que a atividade jurisdicional, ainda quando destinada a resolver matéria relativa a interesses individuais e disponíveis, persegue também objetivos próprios do Estado e que transcendem o âmbito da relação de direito material. E a natureza instrumental do processo impõe que todo o sistema processual seja permeado dessa conotação publicista, para que a jurisdição realmente funcione como instrumento do Estado para a consecução de seus objetivos.

Essa tendência publicista, por sua vez, no que interessa especificamente ao âmbito do presente estudo, tem levado a uma reflexão sobre o papel exercido pelo Estado-Juiz na

\footnotetext{
${ }^{27}$ A respeito da ideia de um Estado Social, Gordillo, utilizando-se da expressão "Estado de Bem-Estar", assim preleciona: "A diferença básica entre a concepção clássica do liberalismo e do Estado de Bem-Estar é que, enquanto naquela se trata tão-somente de colocar barreiras ao Estado, esquecendo-se de fixar-lhe também as obrigações positivas, aqui, sem deixar de manter as barreiras, se lhe agregam finalidades e tarefas às quais antes não se sentia obrigado. A identidade básica entre Estado de Direito e Estado de Bem-Estar, por sua vez, reside em que o segundo toma e mantém do primeiro o respeito aos direitos individuais e é sobre esta base que constrói os seus próprios princípios.” GORDILLO, Agustin. Princípios gerais de direito público. São Paulo: Ed. Revista dos Tribunais, 1977. p. 74.

${ }^{28}$ DINAMARCO, Cândido Rangel. A instrumentalidade do processo, cit., p. 59, nota de rodapé ${ }^{\circ} 89$.

${ }^{29}$ DINAMARCO, Cândido Rangel. A instrumentalidade do processo, cit., p. 59.
} 
direção e instrução do processo, com o consequente incremento de seus poderes ${ }^{30}$, e também sobre o papel das partes e o exercício do contraditório efetivo como fator denotante do caráter democrático do Estado.

Com efeito, a visão publicista do processo ensejou, especialmente nos últimos anos, uma grande abertura para a participação mais ativa do juiz na atividade instrutória, de forma a sanar eventuais deficiências instrutórias das partes no processo, garantindo a formação do convencimento judicial e a prolação de decisões justas.

A esse respeito, Barbosa Moreira destaca que, ao longo dos últimos anos, reformas processuais em vários países têm tratado de reforçar os poderes do juiz na direção do feito e na atividade instrutória, o que, em seu entender, constitui tendência acertada à medida que o processo deve chegar a um resultado justo com o mínimo de dispêndio de tempo e energia $^{31}$.

Assim, a visão do processo civil dispositivo clássico, com um juiz estático e receptivo, tende a ser superada pela ideia de ativismo judicial e o consequente reforço dos poderes diretivos e instrutórios do juiz no processo, a exigir-lhe um comportamento dinâmico e participativo, comprometido com o resultado da atividade jurisdicional, com a consequente relativação da importância do ônus da prova (ao menos sob o prisma

\footnotetext{
${ }^{30} \mathrm{O}$ fenômeno do incremento dos poderes do juiz vem sendo objeto de diversos estudos de processo civil. José Carlos Baptista Puoli, ao tratar dos poderes do juiz em geral e dos fenômenos que têm importado no seu incremento no processo, cita, dentre outros fatores, a valorização dos princípios e a crescente tendência do legislador de fazer uso de conceitos jurídicos indeterminados, impondo ao juiz que primeiro complemente o sentido da norma para, depois, decidir sobre sua aplicabilidade ao caso concreto. (PUOLI, José Carlos Baptista. Os poderes do juiz e as reformas do processo civil. São Paulo: Juarez de Oliveira, 2002. p. 180.) Também Cássio Scarpinella Bueno assim se manifesta sobre o tema: "O consequente incremento dos poderes do juiz a partir de um novo padrão de norma jurídica ou diante de uma nova forma de sua enunciação é inegável. Deixa-se de lado o mito da neutralidade do juiz, como mero aplicador automático da lei, e passa-se a lidar com o juiz que se sabe necessariamente influenciado pelos valores dispersos na sociedade civil e no próprio Estado. O juiz, antes de mero aplicador da lei, dada como pronta e acabada pelo legislador, passa a ser, hoje, compreendido como elo fundamental na cadeia de produção normativa. É ele, isto não tem por que ser negado, criador da norma jurídica. E além de aplicar o direito, o juiz deve ter poderes para instrumentar (realizar), concretamente, a sua decisão, o que, de sua parte, convida a uma reconstrução de outros temas do direito processual civil (...)." (BUENO, Cassio Scarpinella. Curso de sistematizado de direito processual civil, cit., v. 1, p. 116).

${ }^{31}$ José Carlos Barbosa Moreira cita como exemplo as legislações da Suíça, França, Inglaterra e Alemanha. Veja-se que até mesmo na Inglaterra, berço do denominado "adversary system", que confiava às partes, com exclusividade, a atividade probatória, o professor identifica recente movimento de deslocamento do centro do processo das partes para o juiz. A esse respeito confira-se: BARBOSA MOREIRA, José Carlos. A função social do processo civil moderno e o papel do juiz e das partes na direção e instrução do processo. Revista de Processo, São Paulo, n. 37, jan./mar. 1985; O processo civil contemporâneo: um enfoque comparativo. Revista Forense, Rio de Janeiro, v. 370, p. 53-65, nov./dez. 2003; O problema da divisão de trabalho entre juiz e partes: aspectos terminológicos. In: Temas de direito processual: $4^{\mathrm{a}}$ série. São Paulo: Saraiva, 1989 e Os poderes do juiz na direção e instrução do processo. In: processual: $4^{\mathrm{a}}$ série, cit. . Temas de direito
} 
subjetivo) e ainda o reequacionamento da questão da preclusão em matéria de prova, o que será retomado adiante ${ }^{32}$.

\subsection{A ideia do formalismo-valorativo e o denominado "modelo cooperativo de processo"}

Por ora, pelo que se disse nos itens anteriores, já é possível extrair que o desenvolvimento das ideias instrumentalista e publicista do processo têm ensejado, especialmente nos últimos anos, uma reavaliação da denominada "divisão de trabalho" entre juiz e partes no processo, com a revisão do papel de cada qual em todo o iter procedimental.

E, justamente nesse contexto, recente doutrina processual brasileira chega a afirmar a vigência, nos dias atuais, de uma quarta fase metodológica da ciência processual, fundada no marco teórico do "formalismo-valorativo" 33 e correspondente a um modelo de processo denominado "processo cooperativo", pautado pelo permanente diálogo judiciário, colaboração e lealdade entre as pessoas que participam do processo.

As fases metodológicas da ciência processual civil, como já se disse, são fortemente marcadas por sua matriz cultural, eis que, nas palavras de Mitidiero, "toda experiência processual encerra um modo de ver e trabalhar o processo de acordo com a cultura historicamente considerada ${ }^{34}$. O formalismo-valorativo, nesse contexto, constituiria uma nova maneira de pensar o processo, fruto dessa evolução cultural.

O formalismo aqui considerado, entenda-se, não se refere ao seu sentido negativo, de excesso de exigências formais, mas sim à totalidade formal do processo, compreendendo não apenas as formalidades, mas especialmente a delimitação de poderes, faculdades e deveres dos sujeitos processuais, a coordenação de sua atividade, a ordenação do procedimento e a organização do processo.

\footnotetext{
32"Não há mais clima para tanto predomínio do princípio dispositivo, que exclui os comportamentos inquisitivos do juiz no processo e na sua instrução. Aquela idéia radical é espelho das premissas privatistas do processo civil, que hoje é informado reconhecidamente pela natureza de instituto de direito público.” DINAMARCO, Cândido Rangel. Instituições de direito processual civil. vol 1, 6. ed. São Paulo: Malheiros Ed., 2009. p. 52-53.

${ }^{33}$ Expressão cunhada por Carlos Alberto de Oliveira em: OLIVEIRA, Carlos Alberto Alvaro de. Do formalismo no processo civil: proposta de um formalismo-valorativo. 4. ed. rev. atual e aum. São Paulo: Saraiva, 2010.

${ }^{34}$ MITIDIERO, Daniel. Colaboração no processo civil: pressupostos sociais, lógicos e éticos, cit., p. 34.
} 
Segundo Oliveira ${ }^{35}$, o denominado formalismo-valorativo consiste então no formalismo processual cuja estruturação corresponde aos valores constitucionais. Assim, a totalidade formal do processo, ou seja, toda a estruturação e o próprio modo de ser do procedimento deve corresponder aos valores tutelados pela ordem político-constitucional vigente $^{36}$.

Nesse sentido, na perspectiva constitucional do processo civil brasileiro, informado pela democracia não somente representativa, mas também direta, participativa ${ }^{37}$, sobrelevam os valores do diálogo judicial e da participação efetiva das partes na formação da decisão judicial, segundo as regras formais do processo, participação essa que também constitui, ela mesma, um direito fundamental.

Além disso, o formalismo-valorativo, afastando as características de um processo dualístico e privatístico, já ultrapassadas, é informado também pela lealdade e boa-fé, que impõem a cooperação do órgão judicial com as partes e destas com aquele, propugnando o afastamento de situações que façam o processo sucumbir a exigências meramente formais, distantes da verdadeira finalidade da lei. Nesse sentido, Oliveira afirma:

\begin{abstract}
"A sentença final só pode resultar do trabalho conjunto de todos os sujeitos do processo. Ora, a idéia de cooperação, além de exigir, sim, um juiz ativo e leal, colocado no centro da controvérsia, importará senão o restabelecimento do caráter isonômico do processo pelo menos a busca de um ponto de equilíbrio. Esse objetivo impõe-se alcançado pelo fortalecimento dos poderes das partes, por sua participação mais ativa e leal no processo de formação da decisão, em consonância com uma visão não autoritária do papel do juiz e mais contemporânea quanto à divisão de trabalho entre o órgão judicial e as partes" ${ }^{38}$.
\end{abstract}

${ }^{35}$ OLIVEIRA, Carlos Alberto Alvaro de. Do formalismo no processo civil: proposta de um formalismovalorativo, cit., p. 87.

${ }^{36}$ A esse respeito, Galeno Lacerda afirma: “Costumes religiosos, princípios éticos, hábitos sociais e políticos, grau de evolução científica, expressão do indivíduo na comunidade, tudo isto, enfim, que define a cultura e a civilização de um povo, há de retratar-se no processo, em formas, ritos e juízos correspondentes." (LACERDA, Galeno. Processo e cultura. Revista de Direito Processual Civil, v. 3, p. 121, 1961). Daniel Mitidiero, por sua vez, esclarece que: "Sendo o processo civil o meio pelo qual, diante de determinadas crises de colaboração no plano do direito material, se busca velar pela supremacia do direito, natural que seu formalismo reaja às peculiaridades de cada experiência de organização estatal. O formalismo do processo tem de se adequar aos instrumentos pelos quais o Estado busca realizar os fins sociais, assegurando o império do direito." (MITIDIERO, Daniel. Colaboração no processo civil: pressupostos sociais, lógicos e éticos, cit., p. 48).

${ }^{37} \mathrm{Cf}$. Artigo $1^{\circ}$, parágrafo único, da Constituição Federal, que assim dispõe: “Todo o poder emana do povo, que o exerce por meio de representantes eleitos ou diretamente, nos termos desta Constituição."

${ }^{38}$ OLIVEIRA, Carlos Alberto Alvaro de. Do formalismo-valorativo no confronto com o formalismo excessivo. In: DIDIER JR. Fredie (Coord.). Leituras complementares de processo civil. 8. ed. São Paulo: JusPodium, 2010. (Coleção Leituras Complementares). p. 158. 
O denominado formalismo-valorativo encerra também, portanto, a ideia de um justo equilíbrio entre as posições jurídicas do autor, do juiz e do réu no processo. De acordo com Mitidiero:

\begin{abstract}
"Ademais, a democracia participativa, tida mesmo como um direito de quarta dimensão, sugere a caracterização do processo como um espaço privilegiado de exercício direto do poder pelo povo. Nessa quadra, potencializa-se o valor participação no processo, incrementando-se as posições jurídicas das partes no processo, a fim de que se constitua, firmemente, como um democrático ponto de encontro de direitos fundamentais." ${ }^{39}$
\end{abstract}

Essas ideias, por sua vez, constituem a base teórica do denominado "processo civil cooperativo", orientado predominantemente pelos valores justiça, participação leal, segurança e efetividade ${ }^{40}$.

Mitidiero, a propósito de analisar os pressupostos sociais, lógicos e éticos para a formação do denominado "processo civil cooperativo", identifica três perfis possíveis de organização do processo (processo isonômico, assimétrico e cooperativo), correspondentes a três modelos ideais distintos de organização política e social (modelo paritário, hierárquico e colaborativo).

No processo isonômico, correspondente ao modelo paritário de organização social, verifica-se indistinção, em termos políticos, entre o indivíduo, a sociedade civil e o Estado, havendo, consequentemente, no processo, uma relação de paridade entre o juiz e as partes. Esclarece o autor que nesse modelo de organização social, típico da experiência grega e ítalo-medieval, os conflitos eram resolvidos mediante uma racionalidade prática, assumindo a dialética o papel central na solução dos conflitos jurídicos. O juiz, por sua vez, tinha por função somente conduzir formalmente o processo, sem interferir na esfera das partes e sem qualquer iniciativa ou poder de instrução, julgando o processo de acordo com o alegado e provado pelas partes, o que revela uma concepção privatista do processo.

No processo assimétrico, por sua vez, correspondente ao modelo hierárquico de organização política e social, verifica-se radical distinção entre indivíduo, Estado e

\footnotetext{
${ }^{39}$ MITIDIERO, Daniel. Colaboração no processo civil: pressupostos sociais, lógicos e éticos, cit., p. 45.

${ }^{40}$ Ao que nos parece, os fundamentos dessa visão "cooperativa" do processo civil brasileiro já se encontram lançados na concepção instrumentalista do processo, muito bem desenvolvida no Brasil por Cândido Rangel Dinamarco, razão pela qual, em que pese a indiscutível relevância do desenvolvimento das noções de formalismo-valorativo e do denominado "processo cooperativo" - que constituem as premissas teóricas do presente estudo - não estamos certos de que essa perspectiva caracteriza, de fato, um novo marco metodológico da ciência processual civil, mas sim mais uma "revisitação" dos institutos e temas processuais, com base nos bem lançados alicerces da doutrina instrumentalista.
} 
sociedade, colocando-se o Estado numa posição de proeminência, acima do seu povo, o que se reflete naturalmente na hierarquização entre juízes e partes no processo, colocado aquele no vértice da relação processual triangular. Nesse modelo, típico do processo civil romano ao tempo da extraordinaria cognitio $^{41}$ e também do Estado Nacional Moderno, especialmente do processo civil prussiano do século XVIII, o Estado se apropria do monopólio da jurisdição e há amplo poder ao juiz na condução do processo e na atividade probatória, chegando-se a aludir à existência mesmo de um poder discricionário do juiz na direção do processo. O conflito era resolvido utilizando-se de uma racionalidade teórica, matemática, e o contraditório era visto como mera bilateralidade de instância. A conduta processual das partes, no plano ético, era apreciada a partir da ideia de boa-fé subjetiva. Ao Estado, contrariamente, não se colocavam os mesmos limites éticos e "chega-se mesmo a reconhecer o direito de mentir para a obtenção da verdade ${ }^{, 42}$, tida como tarefa precípua do Estado na condução ativa do processo.

Já no processo cooperativo, correspondente ao modelo colaborativo de sociedade, organizada, notadamente, como um Estado Democrático de Direito, indivíduo, Estado e sociedade ocupam posições coordenadas, bastante distintas daquela descrita no modelo assimétrico.

No caso brasileiro, como já se disse, a própria Constituição Federal aponta dentre os objetivos fundamentais do Estado a construção de uma sociedade livre, justa e solidária, e tem como pilares fundamentais a submissão do Estado ao direito e participação social na sua gestão, características essas que acabam repercutindo no processo.

A própria sociedade, nesse contexto, é considerada como um empreendimento de cooperação entre seus membros a fim de alcançar proveito mútuo ${ }^{43}$, e essa característica se reflete diretamente na posição entre juiz e partes no processo, sendo certo que o primeiro

\footnotetext{
${ }^{41}$ A extraordinaria cognitio (cognição extraordinária) corresponde ao terceiro grande período do processo romano, instituído com o advento do Principado (27 a.C.) e vigente até os últimos dias do Império Romano do Ocidente. Sobre as características do processo civil romano no período da cognição extraordinária José Rogério Cruz e Tucci e Luiz Carlos de Azevedo lecionam: "com a ingerência da cognitio extraordinária do princeps ou de seus delegados, em determinadas causas que careciam de tutela jurídica, o procedimento, até então bipartido, passa a desenrolar-se, desde sua instauração, até o final, diante de uma única autoridade estatal (magistrado-funcionário). Assim, a decisão do magistrado, no novo sistema processual, não mais corresponderá a um parecer jurídico (sententia) de um simples cidadão autorizado pelas leis, mas, sim, a um comando vinculante do órgão estatal. Desse modo, pela primeira vez na história do processo privado romano, a sentença não significava mais um ato exclusivo do cidadão e nem apresentava mais caráter arbitral, mas, em verdade, consubstanciava-se na atuação da autoridade do Estado: ex autoritate principis." (CRUZ E TUCCI, José Rogério; AZEVEDO, Luiz Carlos de. Lições de história de processo civil romano, cit., p. 48).

${ }^{42}$ MITIDIERO, Daniel. Colaboração no processo civil: pressupostos sociais, lógicos e éticos, cit., p. 102.

${ }^{43}$ BOURSIER, Marie-Emma. Le principle de loyauté en droit processuel. Paris: Dalloz, 2003. p. 297.
} 
assume dupla posição: paritária no diálogo, na condução do processo, e assimétrica na decisão ${ }^{44}$.

A respeito do papel exercido pelo juiz e a coordenação do trabalho dos sujeitos processuais no curso do processo, Mitidiero assevera:

\begin{abstract}
"A isonomia está em que, embora dirija processual e materialmente o processo, agindo ativamente, fá-lo de maneira dialogal, colhendo a impressão das partes a respeito dos eventuais rumos a serem tomados no processo, possibilitando que essas dele participem, influenciando-o a respeito de suas possíveis decisões (de modo que o iudicium acabe sendo efetivamente um ato trium personarum, como se entendeu ao longo de toda a praxe do direito comum). ${ }^{, 45}$
\end{abstract}

O contraditório se destaca, nesse contexto, como elemento revelador da face democrática do Estado Constitucional no âmbito do processo civil, enquanto instrumento viabilizador do diálogo e cooperação no processo.

No tocante à conduta das partes, no modelo denominado cooperativo de processo destaca-se o "devido processo leal”, pautado pela boa-fé objetiva e reconhecimento do dever de todos os que participam do processo de agir lealmente em juízo, incluindo-se o juiz. É o que se extrai, em nosso ordenamento jurídico, da expressa disposição do artigo 14 do Código de Processo Civil, assim como do artigo 16 do Nouveu Code de Procédure Civile francês, artigo 266-B do Código de Processo Civil português e artigo 247 da Ley de Enjuiciamiento Civil espanhola ${ }^{46}$.

No mais, no que diz respeito à instrução probatória e à busca da verdade no processo - o que interessa de forma mais específica ao escopo do presente estudo - o processo cooperativo, superando a visão privatista do processo civil, se pauta tanto pela investigação oficial, como pelo reforço do contraditório e da atividade probatória desenvolvida pelas partes.

Assim, se, por um lado, o juiz não substitui a atuação das partes na instrução processual, já que tem acesso apenas aos meios, mas não às fontes de prova, por outro, a comunhão de trabalho se evidencia pela necessária colaboração das partes com o Estado-

\footnotetext{
${ }^{44}$ José Carlos Barbosa Moreira, nesse sentido, afirma que “o lema do 'processo social' não é o da contraposição entre juiz e partes, e menos ainda o da opressão destas por aquele: apenas pode ser o da colaboração entre um e outras." BARBOSA MOREIRA, José Carlos. Os poderes do juiz na direção e instrução do processo. In: Temas de direito processual: $4^{\text {a }}$ série. São Paulo: Saraiva, 1989. p. 50.

${ }^{45}$ MITIDIERO, Daniel. Colaboração no processo civil: pressupostos sociais, lógicos e éticos, cit., p. 73

${ }^{46}$ MITIDIERO, Daniel. Colaboração no processo civil: pressupostos sociais, lógicos e éticos, cit., p. 96-97.
} 
juiz para o esclarecimento dos fatos e a indispensável submissão de toda e qualquer prova obtida, ainda que por iniciativa oficial, ao crivo das partes, de forma a possibilitar-lhes influir sobre o valor probante a ser dado pelo magistrado.

O reforço das posições jurídicas das partes e a dupla posição assumida pelo juiz (paritária no desenvolvimento do processo e assimétrica na decisão) são, portanto, marcas determinantes do denominado "processo cooperativo". E essas características se refletem fortemente na condução da atividade probatória.

É nesse contexto e tendo como premissas a instrumentalidade e concepção publicista do processo que nosso estudo cederá então espaço à análise da influência dessa concepção cooperativa do processo na postura das partes e do juiz, notadamente no curso da instrução probatória.

Antes, porém, de avançarmos nesse sentido, devemos considerar a efetividade da tutela jurisdicional, o fator temporal do processo e a exigência de sua razoável duração como limites à atividade instrutória da parte e à própria iniciativa probatória do magistrado, sob pena de eternização do litígio, em violação aos próprios escopos social e político da juridição.

\subsection{Efetividade da tutela jurisdicional e o fator temporal do processo}

A grande preocupação da ciência processual contemporânea está relacionada não apenas ao acesso à ordem jurídica, mas à eficiência da justiça, que se traduz, em última análise, na efetividade da tutela jurisdicional.

Isso porque o Estado, ao proibir aos jurisdicionados o exercício da autotutela, resguardando para si o monopólio da função jurisdicional, assumiu o dever de prestá-la de maneira eficiente, como ocorre com todo e qualquer serviço estatal, por imperativo constitucional, nos termos do artigo 37, caput, da Constituição Federal ${ }^{47}$.

O direito à tutela jurisdicional, portanto, enquanto garantia constitucional fundamental, deve ser entendido como direito à tutela efetiva. E tutela efetiva é aquela

\footnotetext{
${ }^{47}$ Art. 37. A administração pública direta e indireta de qualquer dos Poderes da União, dos Estados, do Distrito Federal e dos Municípios obedecerá aos princípios de legalidade, impessoalidade, moralidade, publicidade e eficiência (...)".
} 
capaz de propiciar ao titular do direito substancial a mesma situação jurídica ou os mesmos efeitos a ele assegurados no plano jurídico-material ${ }^{48}$.

Além disso, somente se pode falar em efetividade do processo se o seu resultado for socialmente útil. Esse é o verdadeiro significado da garantia constitucional da inafastabilidade do controle jurisdicional. A respeito do tema, oportuno transcrever os ensinamentos de Bedaque ${ }^{49}$ :

\begin{abstract}
"Ao afirmar que a lei não poderá subtrair da apreciação do Poder Judiciário lesão ou ameaça a direito, o legislador constitucional estabelece, de um lado, a garantia da ação; de outro, o princípio da inafastabilidade da tutela jurisdicional".

(...)

Essa garantia estabelecida na Constituição Federal não nos assegura o reconhecimento do direito que afirmamos possuir, mas também não significa apenas o acesso livre ao Poder Judiciário. Representa o complexo de poderes constitucionais conferidos a quem necessita da intervenção estatal. É garantia de meio e de resultado, o que não significa identificação com o conteúdo variável pretendido pelos litigantes - o interesse material deduzido -, mas com o valor constante da efetividade instrumental."
\end{abstract}

O direito à prova insere-se, indubitavelmente, no contexto da efetividade da tutela jurisdicional. Isso porque, se a tutela efetiva é aquela que propicia ao titular do direito a situação mais próxima possível da que decorreria naturalmente da observância da norma material, é indispensável a reconstrução tão correta quanto possível dos fatos sobre os quais incidirá a decisão judicial, o que se dá por meio da atividade probatória.

É preciso, pois, que o sistema processual seja dotado de mecanismos adequados, a fim de garantir a quem dele se utiliza o acesso a todos os meios de prova lícitos e legítimos, de forma a propiciar uma solução justa ao litígio. Mas não é só. É preciso também que a entrega da prestação jurisdicional seja realizada em tempo hábil e razoável, propiciando um resultado útil a quem se utiliza do processo.

\footnotetext{
${ }^{48}$ De acordo com Marcelo Lima Guerra: “A tutela jurisdicional se revela efetiva, ou eficaz, quanto menor for, dentro dos limites do praticamente possível, a diferença entre o resultado que ela proporciona à parte vitoriosa e o resultado que esta última obteria, em face do ordenamento jurídico, se não tivesse recorrido ao processo para obter esse mesmo resultado." (GUERRA, Marcelo Lima. Estudos sobre o processo cautelar. 1. ed. 2 tir. São Paulo: Malheiros Ed., 1997. p. 10).

${ }^{49}$ BEDAQUE, José Roberto dos Santos. Direito e processo, cit., p. 72.
} 
Nesse ponto reside, contudo, um dos maiores problemas a serem enfrentados pela ciência processual contemporânea, pois o tempo do processo, naturalmente corrosivo dos direitos, continua a desafiar a garantia constitucional de processo célere e efetivo ${ }^{50}$.

Trata-se aqui do recorrente conflito entre os valores jurídicos da celeridade e da segurança jurídica, que, ao contrário do que se poderia imaginar, não é recente. Carnelutti, nos idos de 1950, já externava preocupação com o denominado "tempo inimigo", contra o qual o juiz deveria lutar ${ }^{51}$.

É sabido que o provimento jurisdicional definitivo não pode ser entregue de forma instantânea, dependendo da prática de uma sequência de atos processuais, previamente estabelecidos em lei e distribuídos em fases procedimentais bem definidas, a fim de resguardar a efetiva e isonômica participação das partes no processo e, ao mesmo tempo, propiciar ao julgador a formação do convencimento.

Dessa noção exsurge o que a doutrina denomina de dano $\operatorname{marginal}^{52}$, correspondente ao lapso temporal imprescindível à realização dos atos processuais, desde a propositura da ação até o provimento definitivo (a duração natural, fisiológica do processo, decorrente da observância do devido processo legal).

No entanto, a excessiva demora na tramitação processual, decorrente não somente do tempo naturalmente necessário à realização dos atos processuais, mas, em especial, da inaceitável lentidão e ineficiência do funcionamento dos órgãos jurisdicionais, e que é um problema universal, sentida em maior ou menor medida nos sistemas jurídicos dos mais diversos países $^{53}$, atua como fator altamente nocivo à efetividade do processo, enquanto instrumento de realização da justiça. Nesse sentido Cruz e Tucci assevera:

\footnotetext{
${ }^{50}$ Cumpre lembrar que a garantia da garantia da "razoável duração do processo e os meios que garantam a celeridade de sua tramitação" foi inserida na Constituição Federal brasileira por meio da Emenda Constitucional n. 45/2004.

${ }^{51}$ CARNELUTTI, Francesco. Diritto e processo. Napoli: Morano, 1958. p. 354.

${ }^{52}$ FINZI, Enrico. Questioni controverse in tema di esecuzione provvisoria. Rivista di Diritto Processuale Civile, Padova, t. 2, p. 50, 1926.

${ }^{53}$ Com relação ao tempo do processo como preocupação universal, Carlos Henrique Ramos comenta: “ $O$ problema da morosidade da justiça é, numa perspectiva comparada, talvez o mais universal de todos os problemas com que se defrontam os tribunais nos nossos dias. Não assumindo a mesma acuidade em todos os países é, no entanto, sentido em todos eles e, virtualmente, também em todos é objeto de debate político. Compreende-se que assim seja. A maior ou menor rapidez com que é exercida a garantia dos direitos é parte integrante e principal dessa garantia e, portanto, da qualidade da cidadania na medida em que esta se afirma pelo exercício dos direitos. Por esta via, o problema da morosidade da justiça constitui uma importante interface entre o sistema judicial e o sistema político particularmente em regimes democráticos" (RAMOS, Carlos Henrique. Processo civil e o princípio da razoável duração do processo. Curitiba: Juruá, 2008. p. 50).
} 
"É inegável, por outro lado, que, quanto mais distante da ocasião tecnicamente propícia for proferida a sentença, a respectiva eficácia será proporcionalmente mais fraca e ilusória. De tal sorte, 'um julgamento tardio irá perdendo progressivamente seu sentido reparador, na medida em que se postergue o momento do reconhecimento judicial dos direitos; e, transcorrido o tempo razoável para resolver a causa, qualquer solução será, de modo inexorável, injusta, por maior que seja o mérito científico do conteúdo da decisão." 54

A duração exagerada e anormal do processo compromete o resultado útil da tutela concedida, representando sério obstáculo à plena satisfação do direito violado. A esse respeito, vale transcrever trecho da obra de $\operatorname{Hoffman}^{55}$ :

\begin{abstract}
"A jurisdição deveria servir para pacificar conflitos, para garantir direitos e manter a tranquiilidade na vida em sociedade, enfim, para que as pessoas se sentissem protegidas. Entretanto, o que se tem visto no sistema brasileiro é que, em razão da exagerada duração do processo, muitas vezes, favorece-se quem não tem razão em detrimento daquele que vem a juízo defender seu direito."
\end{abstract}

As sucessivas reformas por que tem passado a legislação processual civil pátria, especialmente nos últimos anos, visaram, em sua imensa maioria, minimizar as mazelas decorrentes da longa duração do processo, por meio de técnicas processuais tendentes a combater essa deficiência. Até mesmo porque, como já se disse, a racionalização e a celeridade sempre foram ideais da atividade jurisdicional ${ }^{56}$.

Pode-se citar, apenas a título ilustrativo, o crescente prestígio dos institutos da tutela antecipada e da tutela específica das obrigações ${ }^{57}$, a atividade jurisdicional "ininterrupta" e a distribuição imediata dos recursos estabelecidos por emenda constitucional $^{58}$, as recentes alterações promovidas na disciplina do cumprimento de sentença $^{59}$ e execução de títulos extrajudiciais ${ }^{60}$, a modificação da disciplina do recurso de

\footnotetext{
${ }^{54}$ CRUZ E TUCCI, José Rogério. Tempo e processo: uma análise empírica das repercussões do tempo na fenomenologia processual (civil e penal). São Paulo: Ed. Revista dos Tribunais, 1997. p. 65. Em outra passagem dessa mesma obra, o professor, com a agudeza de espírito e a clareza inerente às suas exposições, destaca que "em um número considerável de processos a espera do julgamento assemelha-se à expectativa, para alguns crentes, da chegada do Messias...".

${ }^{55}$ HOFFMAN, Paulo. Razoável duração do processo. São Paulo: Quartier Latin, 2006. p. 17.

${ }^{56}$ Nesse sentido verificar ARRUDA, Miranda. $O$ direito fundamental à razoável duração do processo. Brasília: Brasília Jurídica, 2006. p. 44.

${ }^{57}$ Ambos introduzidos pela Lei 8.952/94 e parcialmente alterados pela Lei 10.444/2002.

${ }^{58}$ Emenda Constitucional n ${ }^{\circ}$ 45/2004, que alterou o artigo 93, XII e XV da Constituição Federal.

${ }^{59}$ Introduzida pela Lei $11.232 / 2005$.

${ }^{60}$ Alterada pela Lei 11.382/2006.
} 
agravo $^{61}$, as súmulas impeditivas de recursos ${ }^{62}$, o julgamento de processos repetitivos ${ }^{63}$, a súmula vinculante ${ }^{64}$, a introdução do processo eletrônico ${ }^{65}$, dentre outros.

Nesse contexto, na análise da divisão de trabalho entre as partes e o juiz e da exigência de colaboração na atividade probatória, o que constitui o objeto específico do presente estudo, não se pode ignorar o fator temporal do processo e a inevitável tensão existente entre a exigência constitucional de sua razoável duração, de um lado, e a amplitude do contraditório e do direito à prova, de outro, o que impõe a reflexão sobre quais seriam os critérios razoáveis para limitar a busca da verdade no processo civil, o que será também alvo de nossas considerações.

\footnotetext{
${ }^{61}$ As mais recentes modificações foram trazidas pelas Leis 11.187/05 e 12.322/2010.

${ }^{62}$ Disciplina introduzida pela Lei 11.276/2006.

${ }^{63}$ Introduzido pela Lei 11.672/2008.

${ }^{64}$ Introduzida pela Emenda Constitucional n ${ }^{\circ}$ 45/2004.

${ }^{65}$ Disciplinado pela Lei 11.419/2006.
} 


\section{DIREITO À PROVA NO PROCESSO CIVIL ATUAL}

\subsection{Noções preliminares: direito à prova - conceito, objeto e finalidade da prova judiciária. Relação entre verdade e prova}

A doutrina reconhece no direito à ampla produção de provas um dos pilares fundamentais do sistema processual contemporâneo. Afinal, de acordo com a sempre oportuna colocação de Dinamarco, sem a sua efetividade (da prova) não seria efetiva a própria garantia constitucional de acesso à justiça ${ }^{66}$.

O direito à prova é entendido, assim, como desdobramento natural do direito de ação e de defesa e, ainda, como postulado inerente às garantias constitucionais do devido processo legal e do contraditório.

Chiovenda afirma que "provare significa formar la convinzione del giudice dela esistenza o non esistenza di fatti rilevanti nel processo" ${ }^{\text {67 }}$. Liebman, por sua vez, acentua que "si chiamano prove $i$ mezzi che servono a dar ela conoscenza di um fato e perciò a fornir ela dimostrazione e a formar ela convinzione dela verità del fato medesimo" ${ }^{\text {68. }}$

Picardi, bem destacando a sua relevância para a concretização dos escopos da jurisdição, conceitua a prova como "o coração do processo" e que tem por objetivo permitir ao juiz atingir a "verdade provável", única passível de ser atingida, dado o limite da consciência humana, de forma a aplicar a norma jurídica de forma justa ${ }^{69}$.

No Brasil, a definição de prova judiciária, segundo a clássica conceituação de Amaral Santos, é subdividida em seus aspectos objetivo e subjetivo. No aspecto objetivo, a prova constitui "o meio destinado a fornecer ao juiz o conhecimento da verdade dos fatos deduzidos em juízo". No sentido subjetivo, a prova consiste na "convicção que as provas

\footnotetext{
${ }^{66}$ DINAMARCO, Cândido Rangel. Instituições de direito processual civil. 6. ed. São Paulo: Malheiros Ed., 2009. v. 3, p. 42 e seg.

${ }^{67}$ CHIOVENDA, Giuseppe. Princippi di diritto processuale civile: le azione, il processo de cognizione. Napoli: Jovene, 1980. § 59.

${ }^{68}$ LIEBMAN, Enrico Tullio. Manuale de diritto processuale civil. 3. ed. Milano: Guiffrè, 1973-1976. $\mathrm{n}^{\circ}$ 164, p. 70.

${ }^{69}$ "La prova è il cuore del processo. Si trata, piú precisamente, di una serie de instrumenti com i quali vengono verificate i ipotesi di fato formulate nel processo, al fin de consentire al giudice de attingere la verità probabile (única verità conseguibile, dati i limiti imamanenti della concoscenza umana) e pervinire, così, ad uma applicazione 'giusta' delle norme giuridiche alia fattispecie controversa" (PICARDI, Nicola. Appunti di diritto processuale civile: processo ordinário di cognizione le impugnación. Milano: Giufrè, 2003. p. 19).
} 
produzidas no processo geram no espírito do juiz quanto à existência ou inexistência dos fatos, 70 .

Para Dinamarco, o direito à prova consiste no "conjunto de oportunidades oferecidas à parte pela Constituição e pela lei, para que possa demonstrar no processo a veracidade do que afirma em relação aos fatos relevantes para o julgamento"71.

Marinoni e Arenhart, por sua vez, definem prova como "todo meio retórico, regulado por lei e dirigido, dentro de parâmetros fixados pelo direito e de critérios racionais, a convencer o Estado-Juiz da validade das proposições, objeto de impugnação, feitas no processo",72.

Os conceitos acima transcritos, como claramente se vê, trazem ínsita a ideia de que a prova se destina à formação do convencimento do julgador, sendo este, portanto, seu destinatário principal, direto e natural.

O reconhecimento da figura do juiz (ou do juízo ${ }^{73}$ ) como destinatário direto e imediato da prova, aliás, é decorrência imediata do princípio da persuasão racional, que determina que o convencimento judicial deve ser alcançado mediante a análise da prova produzida e atendendo aos fatos e circunstâncias constantes dos autos, ainda que não alegados pelas partes ${ }^{74}$.

Esse princípio, por sua vez, é complementado pelo do livre convencimento motivado, que, diferenciando-se do sistema da prova legal (no qual há um valor prédeterminado para as provas), autoriza o juiz a apreciá-las livremente. Essa liberdade, no

\footnotetext{
${ }^{70}$ SANTOS, Moacyr Amaral. Primeiras linhas de direito processual civil. 20. ed. rev. São Paulo: Saraiva, 1999. v. 2, p. 325-332.

${ }^{71}$ DINAMARCO, Cândido Rangel. Instituições de direito processual civil, cit., 6. ed., v. 3, p. 42 e seg.

${ }^{72}$ MARINONI, Luiz Guilherme; ARENHART, Sérgio Cruz. Prova. São Paulo: Ed. Revista dos Tribunais, 2009. p. 151.

${ }^{73} \mathrm{Em}$ nosso entender, a prova, mais que ao juiz, destina-se ao convencimento do juízo, já que, sem embargo das hipóteses de incidência do princípio da identidade física do juiz (cada vez mais raras nos dias atuais, tanto em razão das próprias exceções legais, como da relativização desse princípio em sede jurisprudencial), a competência para o julgamento da causa se relaciona ao juízo e não à pessoa física do magistrado oficiante no processo. Além disso, por força do princípio do duplo grau de jurisdição, caso qualquer das partes interponha recurso de apelação da sentença de primeiro grau, ou em caso de reexame necessário, o material probatório será então destinado ao conhecimento do Tribunal competente, que terá a atribuição de reanalisar todo o acervo probatório e, com isso, pronunciar-se sobre a justiça da decisão prolatada em primeiro grau, exercendo assim o denominado "juízo de revisão".

${ }^{74}$ Artigo 131 do Código de Processo Civil: "O juiz apreciará livremente a prova, atendendo aos fatos $e$ circunstâncias constantes dos autos, ainda que não alegados pelas partes; mas deverá indicar, na sentença, os motivos que the formaram o convencimento.".
} 
entanto, não constitui um salvo-conduto para a arbitrariedade judicial, pois a exigência de fundamentação da decisão constitui freio à atividade jurisdicional ${ }^{75}$.

A exigência de fundamentação das decisões judiciais, aliás, é de tamanha importância para o Estado Democrático de Direito brasileiro que foi elevada à categoria de norma constitucional (artigo 93, IX, da Constituição Federal), constituindo, aliás, a única oportunidade em que na Constituição Federal é empregada a terminologia "sob pena de nulidade".

Trata-se, portanto, inequivocamente, de uma garantia de adstrição da decisão judicial aos fatos tratados e às provas produzidas no processo.

Por outro lado, no entanto, não se pode deixar de reconhecer que também as partes são destinatárias da prova produzida no processo, à medida que não somente têm interesse no seu resultado, como este pode (e deve) conduzir sua conduta dentro e fora do processo. Daí porque, dentre outras razões, como abordaremos no Capítulo 5, item 5.1.4 infra, entendemos inadmissível a rejeição da prova por simplesmente "já estar convencido o juiz".

Yarshell, ao defender a possibilidade de produção de prova sem o requisito da urgência e fora do processo que tem por objeto a declaração do direito - o que será retomado no item 2.3.3 infra - define como direito à prova o "direito simplesmente à produção (obtenção e pré-constituição) de determinada prova, entendido como prerrogativa de invocar do Estado um ato que se esgote aí (direito de buscar e de ter acesso à prova) ${ }^{, 76}$. Neste conceito, as partes são elevadas à categoria de destinatárias diretas e imediatas da prova, que uma vez produzida serve de parâmetro para a definição de sua estratégia processual e também de seu comportamento dentro e fora do processo, servindo, ainda, de baliza segura para avaliação, por parte do juiz, de eventual má-fé ou abuso do direito processual.

Ou seja, no paradigma atual da ciência processual, a prova judicial serve para a formação do convencimento - tanto do juiz como das próprias partes - quanto à existência

\footnotetext{
${ }^{75}$ Nas palavras de Marinoni e Arenhart: “O juiz ao fundamentar não apenas justifica sua posição, como também a legitima enquanto invasão do Estado na esfera jurídica e fática do jurisdicionado que é impedido de se autotutelar." (MARINONI, Luiz Guilherme; ARENHART, Sérgio Cruz. Prova, cit., p. 163).

${ }^{76}$ YARSHELL, Flávio Luiz. Antecipação da prova sem o requisito da urgência e direito autônomo à prova. São Paulo: Malheiros Ed., 2009. p. 207.
} 
ou validade das proposições sobre os fatos dos quais se extrai determinada consequência jurídica.

No que se refere ao seu objeto, conforme já pacificado pela doutrina, destinam-se à prova os fatos controvertidos, relevantes e determinados, que formam, em seu conjunto, o denominado thema probandum.

Taruffo $^{77}$, diferenciando os conceitos de thema probandum e objeto da prova, explica constituir o primeiro o conjunto de fatos jurídicos relevantes cuja existência ou inexistência deve ser demonstrada no curso do processo, e o segundo, o objeto da prova, cada proposição factual, ou, mais simplesmente, cada fato específico, principal ou secundário, que deve ser provado e que está umbilicalmente ligado ao thema probandum.

Em realidade, não se provam os fatos em si, mas sim as afirmações, as proposições das partes a respeito dos fatos dos quais se extrai determinada consequência jurídica ${ }^{78}$.

Com efeito, toda pretensão tem por fundamento um ponto de fato do qual decorrem, ao menos em tese, as consequências jurídicas afirmadas pelas partes e que devem ser objeto da decisão judicial. Mesmo em se tratando de lide que versa sobre as denominadas "matérias exclusivamente de direito", considerando-se que todo direito decorre de um fato, não há como excluir por completo o elemento fático da lide, devendo ser reconhecido pelo juiz, ainda neste caso, os fatos responsáveis pela formação do direito.

Em regra, portanto, devem ser objeto de prova os fatos (ou, mais tecnicamente, as afirmações sobre os fatos) e não o direito. Quanto a este, apenas submetem-se à prova - e desde que assim exigido pelo juiz - o direito municipal, estadual, estrangeiro ou consuetudinário, conforme dispõe o artigo 337 do CPC.

Além disso, também em regra, para que sejam objeto de prova os fatos necessitam ser controvertidos nos autos. Afirmados os fatos por uma das partes e contrastados por afirmação oposta, negando-os, apresentando nova versão, ou ainda outros fatos

\footnotetext{
${ }^{77}$ TARUFFO, Michele. Studi sulla rilevanza della prova. Padova: Cedam, 1970. p. 37.

${ }^{78}$ Como explicita Santís Melendo: "que se an de verificar la realidad de las afirmaciones formuladas; $y$, naturalmente, estas afirmaciones han de tener um contenido, um objeto, una matéria. Las afirmanciones, normalmente, generalmente, se refiren a hechos; he ahi viene la confusión que ace decir que se prueban hechos" (SANTÍS MELENDO, Santiago. La prueba, los grandes temas de derecho probatório. Buenos Aires: Ejea, 1978. p. 13-14). Em sentido contrário, embora sob outro enfoque, Eduardo Cambi, apoiado nos ensinamentos de Echandia, assevera: "Logo, para que a parte obtenha o efeito jurídico pretendido, não lhe basta provar os fatos alegados; é imprescindível que esses fatos estejam em conformidade com a norma jurídica que prevê aqueles efeitos. Daí poder-se sustentar que são os fatos, não as afirmações desses fatos, que integram o objeto da prova e que o juiz, com base no art. 130 do CPC, pode investigar os fatos (secundários), os quais devem integrar o thema probandi, ainda que não alegados pelas partes." (CAMBI, Eduardo. A prova civil: admissibilidade e relevância. São Paulo: Ed. Revista dos Tribunais, 2006. p. 320.
} 
contrastantes com aqueles ou impeditivos de sua ocorrência, nasce a questão, ou ponto controvertido, surgindo daí a necessidade de produção de prova.

O ônus dessa controvérsia, em regra geral, recai sobre o réu, que tem a incumbência de impugnar especificadamente os fatos alegados pelo autor, sob pena de torná-los incontroversos (artigo 302 do CPC). Mas também os fatos alegados pelo réu podem se tornar controvertidos e demandar a produção de prova, tal como ocorre em caso de reconvenção ou de afirmação de fatos impeditivos, modificativos ou extintivos do direito do autor, casos em que ao autor caberá impugná-los, sob pena de deixá-los incontroversos.

Há casos, no entanto, em que o ordenamento jurídico exige a prova de fatos (ou melhor, da alegação sobre os fatos) ainda que não tenham sido impugnados pela parte contrária, ou seja, ainda que sejam incontroversos nos autos. É o que ocorre nas hipóteses envolvendo direitos indisponíveis (para os quais a lei não admite confissão) e quando a lei exige forma especial de validade do ato jurídico, o que reflete diretamente na prova, como é o caso da propriedade imobiliária, casamento, etc.

Por outro lado, hipóteses há em que as alegações, apesar de controvertidas, dispensam a atividade probatória, o que ocorre quando se trata de fatos notórios ou em cujo favor milita presunção legal de existência ou de veracidade (artigo 334, incisos I e IV do CPC).

No caso dos fatos notórios, assim entendidos aqueles de conhecimento geral, por não existir dúvida, a lei dispensa a prova. Dinamarco, no entanto, alerta para o perigo de se alargar demasiada e imprudentemente o conceito e extensão de fatos notórios, a ponto de se dispensar a prova à vista de meros rumores, boatarias ou veiculação (muitas vezes sensacionalista e distorcida) por parte da imprensa. E, em arremate, assevera que "é necessário que o conhecimento do fato integre o comumente sabido, ao menos em determinado estrato social",79.

Quanto às presunções, sendo absolutas, dispensam de forma definitiva a prova. Sendo relativas, embora também dispensem a prova de quem alega, a parte contrária, uma vez infirmando-as, deve produzir prova a seu favor, com vistas a desfazer a presunção, daí a ideia de que as presunções relativas, em realidade, invertem o ônus da prova.

Pois bem, além de, em regra, controvertidos, somente são objeto de prova as proposições sobre fatos relevantes e determinados.

\footnotetext{
${ }^{79}$ DINAMARCO, Cândido Rangel. Instituições de direito processual civil, cit., 6. ed., v. 3, p.63.
} 
Fatos relevantes são aqueles que, além de relacionados com a questão sub judice, são capazes de influir no julgamento da causa. São irrelevantes e, portanto, inúteis e dispensáveis, fatos que, mesmo que relacionados com aqueles da causa, são indiferentes para a decisão a ser prolatada. Amaral Santos ${ }^{80}$ destaca serem também irrelevantes os fatos cuja prova seja impossível, o que pode se dar por disposição legal (cita como exemplo a presunção absoluta) ou pela natureza do fato (exemplo é a proibição de prova exclusivamente testemunhal de contrato acima do valor fixado em lei).

Fixado, assim, seu objeto, cabe então tratar, agora de forma um pouco mais detida, da finalidade da prova, estabelecendo-se o necessário e indispensável paralelo entre verdade e prova.

A influência da verdade sobre o processo e, mais amplamente, sobre o resultado da atividade jurisdicional remonta ao processo romano, que permitia ao iudex (juiz privado) simplesmente se abster de julgar caso não conseguisse se convencer da verdade no processo, declarando o "sib non liquere", hipótese em que era nomeado outro juiz para a prolação da decisão ${ }^{81}$. Ou seja, tal a importância da reconstrução dos fatos e da obtenção da verdade no processo como pressuposto da decisão, que o juiz poderia simplesmente se abster de julgar caso não se sentisse convencido da ocorrência dos fatos.

Nos dias atuais, o incremento dos poderes instrutórios do juiz e, conforme entendemos, a exigência de colaboração das partes e do juiz na atividade probatória, decorrem de um compromisso cada vez maior com a qualidade das decisões jurisdicionais, não se contentando o jurisdicionado, tampouco o próprio Estado, com a simples resposta estatal, mas sim com a composição justa do litígio que lhe foi submetido à apreciação.

Nessa ordem de ideias, como bem destacado por Bedaque ${ }^{82}$, não se pode mais admitir, no atual estágio da ciência processual, a antiga diferença estabelecida entre o campo do processo penal e civil no sentido de que o primeiro perseguiria a denominada "verdade material" ao passo que o segundo se contentaria com a "verdade formal". Nas palavras Barbosa Moreira “a verdade é uma e interessa a qualquer processo, se bem que a

\footnotetext{
${ }^{80}$ SANTOS, Moacyr Amaral. Primeiras linhas de direito processual civil, cit., v. 2, p. 340 e seg.

${ }^{81}$ Ver a respeito: SURGIK, Aloísio. Lineamentos do processo civil romano. Curitiba: Livro é Cultura, 1990. p. 71.

${ }^{82}$ BEDAQUE, José Roberto dos Santos. Poderes instrutórios do juiz. 4. ed. São Paulo: Ed. Revista dos Tribunais, 2009. p. 145.
} 
justiça possa (e às vezes deva) renunciar - na área civil e na penal - à sua reconstituição completa, em atenção a valores de igual dignidade" ${ }^{83}$.

Para a professora Grinover o termo verdade material só pode ser admitido na atualidade se tomado no seguinte sentido: por um lado, como verdade subtraída à influência que as partes, por seu comportamento processual, queiram exercer sobre ela, e, de outro, como uma verdade que, não sendo "absoluta" ou "ontológica", há de ser antes de tudo uma verdade judicial, prática, e atenta aos postulados do devido processo legal, ou seja, uma "verdade processualmente válida",84.

A par das dificuldades que tem enfrentado a doutrina para estabelecer a exata correlação entre prova, processo e verdade, o que se verifica é que a distinção entre "verdade formal" e "verdade material" vem sendo sistematicamente rechaçada pela doutrina processual moderna, pois já não mais se concebe razão para que a reconstrução dos fatos no processo penal se dê de forma substancialmente diversa do processo civil.

Aliás, como já se disse, a ciência processual já superou há muito a ideia de que, na seara do processo civil, a solução do litígio interessaria somente às partes litigantes. No atual estágio de desenvolvimento do estudo do processo, é incontestável o interesse do Estado na pacificação dos conflitos, qualquer que seja a sua natureza, enquanto finalidade última da atividade jurisdicional.

Além disso, se o processo penal lida com o valor fundamental da liberdade, o processo civil também é aplicável em matérias igualmente não sujeitas à disposição das partes, como as demandas relacionadas ao direito de família, aos direitos metaindividuais, além de se aplicar também a litígios atinentes a matérias de direito público, como direito tributário e constitucional ${ }^{85}$.

É bem verdade que, no processo civil, tratando-se de direitos disponíveis, a confissão ou mesmo a não impugnação especificada dos fatos acarreta presunção - ainda que relativa - de veracidade, autorizando o juiz a decidir desde logo a lide, ao passo que no processo penal é amplamente rejeitada a antiga idéia de confissão como a "rainha das provas", sendo ela insuficiente para gerar a condenação do acusado quando não amparada

\footnotetext{
${ }^{83}$ BARBOSA MOREIRA, José Carlos. A Constituição e as provas ilicitamente obtidas. In: Temas de direito processual: sexta série. São Paulo: Saraiva, 2006. p. 118.

${ }^{84}$ GRINOVER, Ada Pellegrini. O processo em sua Unidade II, cit., p. XV.

${ }^{85}$ A esse respeito consultar: BARBOSA MOREIRA, José Carlos. A Constituição e as provas ilicitamente obtidas, cit. e MARINONI, Luiz Guilherme; ARENHART, Sérgio Cruz. Prova, cit.
} 
por outros elementos de convicção, assim como inexiste a figura da revelia ${ }^{86}$. Não é menos certo, contudo, que também na esfera civil os efeitos da confissão quanto à matéria fática vêm sendo abrandados pela doutrina, entendendo-se pela necessidade de instrução probatória na hipótese de ausência de verossimilhança das alegações ou nos casos em que os documentos contrariem a presunção legal de veracidade das afirmações, o que também se insere no contexto dos poderes instrutórios do juiz.

Barbosa Moreira $^{87}$, na mesma linha de pensamento ora defendida, assevera que a Constituição Federal equiparou com acerto o processo civil ao processo penal à medida que, ao assegurar aos litigantes, em processo judicial ou administrativo, a amplitude do contraditório e da ampla defesa, não faz distinção quanto à natureza dos bens jurídicos envolvidos.

Mas o tema da busca da verdade, é necessário dizer, é assunto cercado de aspectos filosóficos, cujo tratamento fugiria ao âmbito do presente trabalho.

A esse respeito, então, reputamos suficiente consignar que a ideia de busca da verdade sobre fatos pretéritos parece estar superada por outros ramos do conhecimento ${ }^{88}$. Assim, por mais que o juiz, partes e terceiros (peritos, testemunhas, etc.) se esforcem para a reconstrução dos fatos, o resultado desse conjunto probatório nada mais permitirá que um juízo de verossimilhança e probabilidade do que se passou, que não se confunde com a essência dos fatos em $\mathrm{si}^{89}$.

\footnotetext{
${ }^{86}$ Nesse sentido são as lições de Mirabete: "Antigamente considerada como a 'rainha das provas' (probatio probatissima), a confissão não desfruta hoje de tanto prestígio diante do sistema adotado pela nossa legislação, já que todas as provas são relativas, nenhuma delas tendo valor decisivo (Exposição de Motivos, Item VII). Uma das características da confissão, como prova, é a da relatividade de seu valor. Por isso o juiz deve confrontar a confissão com os demais elementos probatórios dos autos para ver se é compatível com estes." (MIRABETE, Julio Fabrini. Código de Processo Penal interpretado. 8. ed. São Paulo: Atlas, 2001. p. 469).

${ }^{87}$ BARBOSA MOREIRA, José Carlos. A Constituição e as provas ilicitamente obtidas, cit., p. 118.

${ }^{88}$ Nesse sentido Taruffo destaca que "o jurista não consegue mais estabelecer que coisa seja a verdade dos fatos no processo, e a que coisa servem as provas, sem defrontar-se com escolhas filosóficas e epistemológicas de ordem mais geral. A expressão 'verdade material', e outras expressões sinônimas, transformam-se em etiquetas privadas de significado se não se ligam ao problema geral da verdade. Deste ponto de vista, o problema da verdade dos fatos no processo não é mais que uma variante específica deste problema mais geral." (TARUFFO, Michele. La prova dei fatti giuridici: nozione generali. Milano: Giuffrè, 1992. p. 5).

${ }^{89}$ "No processo não se busca a 'verdade', mas são empregados meios capazes de dar condições para formação do convencimento judicial acerca dos fatos, na medida exata do possível e do razoável para permitir um julgamento. Em poucas palavras, na sentença a verdade não é a meta, mas a expectativa, ou, tecnicamente, a máxima probabilidade. Tanto assim o é, que no caso de incidência de uma presunção legal relativa, não havendo prova em contrário, o juiz julga com base no fato presumido, o que nada mais é, do que julgar de acordo com a probabilidade e não com a demonstração efetiva do que resultaria do fato provado" (FERREIRA, William dos Santos. Princípios fundamentais da prova cível. 2008. Tese (Doutorado) - Pontifícia Universidade Católica de São Paulo, São Paulo, 2008. p. 246).
} 
Com efeito, nas palavras de Carnelutti:

\begin{abstract}
"é bem fácil observar que a verdade não pode ser mais que uma, de tal maneira que, ou a verdade formal ou jurídica coincide com a verdade material, e não é mais que verdade, ou discrepa dela, e não é senão uma não verdade, de tal maneira que, sem metáfora, o processo de busca submetido a normas jurídicas que obrigam e deformam sua pureza lógica, não pode na realidade ser considerado como um meio para o conhecimento dos fatos, senão para uma fixação ou determinação dos próprios fatos, que pode coincidir ou não com a verdade dos mesmos e que permanece por completo independente deles" 90 .
\end{abstract}

Justamente por essa razão é que a doutrina entende que a convicção judicial sobre os fatos, longe da coincidência com a realidade, consistiria na "máxima probabilidade", na "certeza razoável",92, na "verdade possível", ou no "alto grau de probabilidade"94.

Ademais, tratando-se de "reconstrução" de fatos pretéritos, a certeza sobre sua existência ou ocorrência não escapa do subjetivismo, seja das pessoas que o assistiram, das partes que sobre ele depõem ou do juiz que valorará sua ocorrência. A interpretação sobre um fato ou sobre a prova desse fato tem um componente subjetivo indissociável, eis que essa análise já envolve certa valoração do fato, inviabilizando o conhecimento do fato objetivo, tal como aconteceu ${ }^{95}$.

Também de acordo com as seguras lições de Yarshell ${ }^{96}$, não se consegue superar a clássica noção de que a verdade está nas coisas, ao passo que a certeza está no espírito. Se a certeza representa a superação dos motivos divergentes de certa proposição, ainda assim a desconsideração desses mesmos motivos está no espírito de quem avalia (avaliação intelectual dos motivos determinantes). Daí porque, no entender de Yarshell, a certeza ressalva feita ao caráter objetivo que decorre da sentença soberanamente transitada em

\footnotetext{
${ }^{90}$ CARNELUTTI, Francesco. A prova civil. 2. ed. Campinas: Bookseller, 2002. p. 52.

${ }^{91}$ CARNELUTTI, Francesco. Como se hace um processo. Bogotá: Temis, 1994. p. 528.

${ }^{92}$ PATTI, Salvatore. Libero convencimento e valutazione delle prove. Rivista di Diritto Processuale, Milano, ano 40, n. 3, p. 503, 1985.

${ }^{93}$ RANGEL, Rui Manuel de Freitas. O ónus da prova no processo civil. Coimbra: Almedina, 2000. p. 118.

${ }^{94}$ ROSEMBERG, Leo. La carga de la prueba. Traducción de Ernesto Krotoschin. Buenos Aires, Ed. Juridicas Europa-America, 1956. p. 213.

${ }^{95} \mathrm{Na}$ clássica lição de Piero Calamandrei, sobre a relação entre os advogados e a verdade: "Ponham-se dois pintores diante de uma mesma paisagem, um ao lado do outro, cada um com seu cavalete, e voltem uma hora depois para ver o que cada um traçou em sua tela. Verão duas paisagens absolutamente diferentes, a ponto de parecer impossível que o modelo tenha sido o mesmo. Dir-se-ia, nesse caso, que um dos dois traiu a verdade?” (in, Eles, os juízes, vistos por um advogado. São Paulo: Martins Fontes, 1995. p. 123).

${ }^{96}$ YARSHELL, Flávio Luiz. Antecipação da prova sem o requisito da urgência e direito autônomo à prova, cit., p. 245.
} 
julgado - traduz-se não mais que em verossimilhança e probabilidades e, portanto, na avaliação de riscos.

Segundo Marinoni e Arenhart, aliás, isso explica o porquê, diante de processos idênticos, em que foram produzidas as mesmas alegações e as mesmas provas, dois juízes diferentes poderem chegar a conclusões completamente antagônicas. Segundo os professores:

\footnotetext{
“... é que a prova não se presta à reconstrução da verdade - caso em que as conclusões judiciais, como exercício de mero silogismo, deveriam ser, inexoravelmente, as mesmas - mas a apoiar a argumentação retórica das partes (e também do magistrado) sobre a controvérsia exposta." ${ }^{.97}$
}

Marinoni e Arenhart, apoiados na teoria de Habermas, entendem que a verdade sobre um fato é um conceito dialético, construído com base na argumentação dos sujeitos cognoscentes. Assim, a verdade não se descobre, mas se constrói com a argumentação. Justamente por essa razão é que a função da prova, para esses professores, não é a reconstrução dos fatos, mas sim tem papel retórico, enquanto elemento de argumentação dirigido a convencer o magistrado a respeito das afirmações sobre fatos feitas pelas partes e de qual delas deverá ser beneficiada pela decisão a ser proferida pelo órgão estatal.

Fixados esses conceitos, cumpre então a analisar o chamado "direito à prova" no contexto das posições ativas e passivas que emergem da relação jurídica processual.

\subsection{Posições ativas e passivas assumidas pelas partes e pelo juiz na relação jurídica processual}

A relação jurídica processual, segundo Dinamarco, "é a alma das atividades" desenvolvidas no processo pelos sujeitos processuais ${ }^{98}$. Ela consiste numa relação extremamente complexa e dinâmica, que expressa uma teia de vínculos entre os sujeitos processuais, que se desenvolvem e se sucedem ao longo do arco procedimental. A esse respeito Dinamarco observa:

"Juiz, demandante e demandado não são ligados por um só vínculo - um só direito, uma só obrigação, um só dever, um só poder - de modo que,

\footnotetext{
${ }^{97}$ MARINONI, Luiz Guilherme; ARENHART, Sérgio Cruz. Prova, cit., p. 54.

${ }^{98}$ DINAMARCO, Cândido Rangel. Instituições de direito processual civil, cit., 6. ed., v. 2, p. 201.
} 
cumprido o ato, o vínculo como um todo se desfizesse. No processo o cumprimento de um ato extingue uma situação jurídica, mas de imediato cria outra, que por sua vez conduz a um novo ato e o novo ato gera nova situação jurídica - e, assim, sucessivamente, até que o processo seja extinto e a tutela jurisdicional concedida, mediante o último dos atos do procedimento." 99

A situação ou posição subjetiva, assim, como assinala Cordero, diz respeito a uma conduta abstrata ou comportamento hipotético previsto na lei e atribuído a um sujeito ${ }^{100}$. Embora ainda exista bastante controvérsia acerca de quais são as situações ou posições ${ }^{101}$ subjetivas de que são titulares os sujeitos, costuma-se subdividi-las em duas categorias, de acordo com a conduta nelas expressa: situações jurídicas ativas e situações jurídicas passivas.

As posições subjetivas ativas, segundo essa classificação, correspondem a permissões do ordenamento jurídico para a realização de determinada atividade, segundo o interesse de seu titular. São sempre favoráveis ao titular, porque permitem a prática de um ato de seu interesse ou a exigência da prática de algum ato por outro sujeito processual ${ }^{102}$.

As situações jurídicas ativas caracterizam-se como faculdades (condutas permitidas e que se exaurem na esfera jurídica do próprio agente) ou poderes (condutas permitidas e que destinam a modificar a esfera jurídica alheia) ${ }^{103}$.

Carnelutti ${ }^{104}$, dentre as posições jurídicas ativas, inclui também o direito subjetivo, que é negada por Dinamarco ${ }^{105}$, com apoio na doutrina de Fazzalari, por entender ser

\footnotetext{
${ }^{99}$ DINAMARCO, Cândido Rangel. Instituições de direito processual civil, cit., 6. ed., v. 2, p. 204.

${ }^{100}$ Segundo Cordero, a situação subjetiva equivale à posição na qual se encontra um sujeito que detém todas as condições para a eventual prática de um ato ou exercício de um comportamento, o qual será valorado positiva ou negativamente, segundo a sua conformidade ou não com um modelo previamente estabelecido na norma. (cf. CORDERO, Franco. Le situazione soggettive nel processo penale. Torino: Giapichelli, 1957).

${ }^{101}$ Esses termos são aqui usados como sinônimos, muito embora não se desconheça a distinção havida por alguns estudiosos, dentre os quais Elio Fazzalari, que sustenta ser a situação subjetiva mais ampla que a posição subjetiva, já que a primeira seria formada por um agregado de posições. V. a respeito FAZZALARI, Elio. Note in tema de diritto e processo. Milano: Giuffrè, 1957. p. 112.

${ }^{102}$ DINAMARCO, Cândido Rangel. Instituições de direito processual civil, cit., 6. ed., v. 2, p. 206.

${ }^{103}$ Helena Najjar Abdo, reafirmando a correlação existente entre as posições jurídicas assumidas pelos sujeitos no desenvolvimento da relação jurídica processual, cita ser comum que uma faculdade, assim como outras situações subjetivas processuais, venha acompanhada de um poder ou de outra situação subjetiva. Como exemplo, esclarece que a parte sucumbente tem a faculdade de recorrer, mas, quando assim o faz, também exerce um poder, criando para o juiz o dever de apreciar o recurso, assim como se desincumbe de um ônus, que impede a preclusão da decisão. (cf. ABDO, Helena Najjar. O abuso do processo. São Paulo: Ed. Revista dos Tribunais, 2007. p. 66).

${ }^{104}$ CARNELUTTI, Francesco. Sistema di diritto processuale civile. Padova: Cedam, 1936. vol 1, n. 11, p. 25.

105“Só por costume ou comodidade tolera-se o emprego do vocábulo direito, no processo. Fala-se em direito à prova, direito à sentença de mérito, etc., como modos simplificados e mais práticos de aludir ao poder de
} 
inapropriado falar em direitos e obrigações no processo, já que estes significam situação de vantagem ou desvantagem em relação a um bem da vida, o que não se verifica no processo, em que os atos têm por objeto imediato criar situações processuais e não a obtenção de um bem da vida ${ }^{106}$.

As posições jurídicas passivas, por sua vez, representam uma necessidade, que impele o sujeito a praticar um ato ou a aceitar um ato alheio. São situações desfavoráveis ao seu titular. São situações jurídicas passivas o dever (imperativo de conduta instituído no interesse de pessoa distinta do agente cuja conduta se pretende vincular e cuja inobservância acarreta a imposição de sanções) e o ônus (imperativo do próprio interesse, faculdade cujo não exercício pode acarretar prejuízo processual ao próprio onerado).

Existe, ainda, uma terceira modalidade de posição jurídica passiva que é a sujeição (necessidade de obedecer a um determinado comando) ${ }^{107}$. É a situação em que se encontra a parte, forçada a suportar os efeitos do provimento jurisdicional, submetendo-se, pois, à autoridade do órgão jurisdicional $^{108}$. A esse respeito Dinamarco esclarece:

"Durante todo o processo estão as partes em permanente estado de
sujeição ao Estado-Juiz, conceituada esta como a impossibilidade de
evitar os efeitos dos atos alheios (Carnelutti). O contraposto da sujeição é
a autoridade, também exercida do começo ao fim do processo e que é
expressão do poder estatal. (...) A impossibilidade de evitar os efeitos do
ato do juiz, que caracteriza a sujeição das partes, é manifestação da
inevitabilidade da jurisdição e do poder estatal.".109

A sujeição, no entanto, não pressupõe sequer uma conduta do sujeito, quer comissiva ou omissiva, porque se traduz simplesmente na circunstância de suportar os efeitos de uma conduta alheia. Daí porque parte da doutrina, como Cordero, não classifica

exigir a produção de prova, exigir a sentença etc. $O$ 'direito' de ação não é um autêntico direito subjetivo, mas o poder de criar condições para que o Estado possa decidir e, se for o caso, conceder a tutela jurisdicional ao autor" DINAMARCO, Cândido Rangel. Instituições de direito processual civil, cit., 6. ed., v. 2, p. 216.

${ }^{106}$ Para Miguel Reale, a situação subjetiva é a "possibilidade de ser, pretender ou fazer algo, de maneira garantida, nos limites atributivos da regra de direito". Já o direito subjetivo apenas passa a existir quanto a "situação subjetiva implica a possibilidade de uma pretensão, unida à exigibilidade de uma prestação ou de um ato de ontrem" (REALE, Miguel. Lições preliminares de direito. 27. ed. São Paulo: Saraiva, 2006. p. 257-260).

${ }^{107}$ CARNELUTTI, Francesco. Sistema di diritto processuale civile, cit., n 21, p. 55.

${ }^{108}$ LIEBMAN, Enrico Tullio. Manual de direito processual civil. Tradução e notas de Cândido Rangel Dinamarco. 3. ed. São Paulo: Malheiros, Ed., 2005. v. 1, p. 123.

${ }^{109}$ DINAMARCO, Cândido Rangel. Instituições de direito processual civil, cit., 6. ed., v. 2, p. 207. 
a sujeição entre as posições ou situações processuais, já que a sujeição se limita, em seu entender, a um pálido reflexo do poder exercido por outrem ${ }^{110}$.

Com relação ao juiz, as situações jurídicas que ocupa no processo constituem desdobramentos do poder estatal, sendo os poderes do juiz necessários e indispensáveis à direção do processo, ao julgamento das pretensões e à imposição coativa dos efeitos desse julgamento.

Assim, e no contexto de um Estado Democrático de Direito, como é o caso brasileiro, que pressupõe a supremacia do Direito e a sujeição do próprio Estado ao ordenamento jurídico, a cada poder do juiz corresponde-lhe também um dever de cumprilo, sendo as posições jurídicas ocupadas pelo juiz, ao mesmo tempo, ativas e passivas, denominadas poderes-deveres. Komatsu, ao analisar detidamente os deveres do juiz, assim assinala:

\begin{abstract}
"O dever, designado pela ordem jurídica como gênero amplo de imposição de comportamento, é um comando cujo desrespeito acarreta sanções ao lesante, que, no caso específico do juiz, gera as diversas hipóteses de responsabilidade, decorrente da função judicial. (...) Esse dever jurídico incide sobre a conduta do juiz como uma limitação, atuando como força vinculatória de sua ação, contornando sua atividade segundo aquele molde prescrito pela lei. A ação do juiz é restringida por esse dever jurídico. Tem a necessidade de agir nesses termos: é esse o seu campo de ação. Se extravasa a demarcação circunscrita de seus deveres legais, propulsiona, em contrapartida, uma sanção."111
\end{abstract}

Com relação às partes, suas posições jurídicas ativas têm por fundamento as garantias constitucionais do acesso à justiça, contraditório e ampla defesa, sendo as situações passivas, por sua vez, inerentes e indispensáveis ao devido processo legal.

No que se refere às posições ativas, tanto a faculdade como o poder têm como característica a permissão de uma conduta. O poder insere-se numa ideia de supremacia, que se caracteriza pela capacidade de produzir consequência pré-definida na esfera jurídica alheia, normalmente com o surgimento de uma situação de dever perante o outro sujeito ${ }^{112}$

\footnotetext{
${ }^{110}$ ABDO, Helena Najjar. O abuso do processo, cit., p. 70.

${ }^{111}$ KOMATSU, Roque. Notas em torno dos deveres processuais dos juízes. In: SALLES, Carlos Alberto de (Coord.). As grandes transformações do processo civil brasileiro: homenagem ao professor Kazuo Watanabe. São Paulo: Quartier Latin, 2009. p. 691 e 696.

${ }^{112}$ CORDERO, Franco. Le situazione soggettive nel processo penale, cit.
} 
(exemplo é o poder de recorrer, a que corresponde o dever do órgão jurisdicional de prolatar nova decisão). Na faculdade há uma conotação simplesmente de liberdade ${ }^{113}$.

As faculdades processuais puras, no entanto, são raras e geralmente correspondem a atividades de menor importância para o processo, porque se esgotam na esfera jurídica exclusiva do agente. Exemplo clássico é a possibilidade de apresentar defesa no primeiro ou último dia do prazo, hipótese em que não há qualquer interferência ou modificação na esfera jurídica alheia, seja da parte contrária seja do juiz.

No tocante às posições jurídicas passivas das partes, diferenciam-se os deveres dos ônus. Os deveres, como já frisado, são imperativos de conduta instituídos no interesse de pessoa distinta do agente cuja conduta se pretende vincular. A principal característica do dever, pois, consiste no fato de ser realizado no interesse alheio, ou seja, de privilegiar um interesse não necessariamente comungado pelo sujeito da situação subjetiva passiva ${ }^{114}$.

Além disso, conforme ensinamento de Dinamarco ${ }^{115}$, os deveres são instituídos para o correto exercício da jurisdição, que é de interesse público, incorrendo em ilícito aquele que o descumpre. Justamente por isso, autorizam o uso de meios coativos para sua observância, assim como a imposição de verdadeiras sanções. Exemplo frequentemente citado é o dever de lealdade imposto às partes, cuja transgressão a lei sanciona com a pena de litigância de má-fé.

Os deveres impostos às partes no processo, portanto, são o contraposto da autoridade exercida pelo juiz, diferenciando-se da mera sujeição por não se limitarem a uma tolerância ou submissão aos efeitos da autoridade do juiz, consubstanciando-se num típico dever de conduta definido por lei.

Já o ônus, muito presente na prática do processo civil, constitui o imperativo do próprio interesse e consiste em situações de necessidade de realizar determinado ato para evitar prejuízo processual ou para obter determinada situação de vantagem. O descumprimento de um ônus não acarreta qualquer prejuízo à situação jurídica do outro litigante ou ao interesse público, ensejando consequências processuais desfavoráveis apenas ao próprio litigante.

\footnotetext{
${ }^{113}$ CARNELUTTI, Francesco. Sistema di diritto processuale civile, cit., n. 22, p. 57.

${ }^{114}$ ABDO, Helena Najjar. O abuso do processo, cit., p. 67.

${ }^{115}$ DINAMARCO, Cândido Rangel. Instituições de direito processual civil, cit., 6. ed., v. 2, p. 207.
} 
Como explica Carnelutti ${ }^{116}$, dever e ônus possuem um mesmo elemento formal - a imposição de um vínculo à vontade do sujeito - sendo que no ônus o vínculo serve ao interesse do próprio sujeito ao passo que no dever é imposto no interesse alheio.

Lent, por outro ângulo de análise, propõe que a distinção entre ônus e dever se dá à medida que, no primeiro, a lei confere ao sujeito a faculdade de determinar o próprio comportamento, ou seja, o comportamento da parte fica sob seu livre querer, ao passo que livre querer e dever se opõem, pois onde existe dever deixa de existir liberdade de comportamento. Ou seja, existindo um dever, a norma exige determinada conduta ou desaprova determinado comportamento ${ }^{117}$.

Tradicionalmente, o exemplo clássico trazido pela doutrina diz respeito ao ônus da prova, o que particularmente nos interessa no âmbito do presente trabalho. A ideia parte da consideração de que o descumprimento do ônus da prova pela parte não acarreta consequências prejudiciais ou malefícios ao outro litigante, tampouco interfere na esfera de deveres do juiz, mas apenas na do próprio sujeito onerado.

Em nosso entender, no entanto, e apoiados também nos ensinamentos de Yarshell ${ }^{118}$, a caracterização da prova como simples ônus da parte (entendido como imperativo do próprio interesse) é insuficiente para a explicação do fenômeno, especialmente diante do crescente reconhecimento dos poderes instrutórios do juiz e da consideração de que o alcance da finalidade da prova, qual seja, o esclarecimento dos fatos controvertidos, não interessa somente às partes litigantes, mas precipuamente ao Estado, como instrumento apto à consecução dos escopos jurídico e social da jurisdição.

Não se desconhece, é verdade, que a técnica legislativa fundada nos ônus processuais é de grande serventia para o impulso processual, servindo de força motriz do procedimento $^{119}$. Isso porque, o risco de prejuízo processual causado à parte pelo não cumprimento de determinado ônus funciona como eficaz ferramenta (até mesmo psicológica) de encorajamento para a prática do ato. Além disso, em caso de descumprimento, a aplicação da consequência processual costuma, em regra, ser ferramenta mais célere e efetiva para as finalidades do processo do que a aplicação das

\footnotetext{
${ }^{116}$ CARNELUTTI. Francesco. Sistema di diritto processuale civile, cit., n. 22, p. 57

${ }^{117}$ LENT, Friedrich. Diritto processuale civile tedesco, n. 26, p. 105 apud CRESCI SOBRINHO, Elicio de. Contribuição ao estudo do dever de veracidade das partes no processo civil: aspectos do Anteprojeto de Codigo de Processo Civil, de autoria do professor Alfredo Buzaid. São Paulo, Lael, 1972.

${ }^{118}$ YARSHELL, Flávio Luiz. Antecipação da prova sem o requisito da urgência e direito autônomo à prova. cit.

${ }^{119}$ ABDO, Helena Najjar. O abuso do processo, cit., p. 69.
} 
penas processuais. Nesse sentido é a lição de Cresci Sobrinho, fundado na doutrina de Lent:

\footnotetext{
"As consequências jurídicas prejudiciais que ocorrem pelo não adimplemento de um ônus, funcionam mais fortemente que um procedimento coativo para o cumprimento de um dever. O legislador que atribui valor à rapidez e facilidade processuais, estará mais inclinado a trabalhar com ônus do que com deveres." 120
}

Casos há, no entanto, em que a simples aplicação da técnica do ônus é incapaz de sanar a lacuna probatória. Além disso, as próprias regras processuais relacionadas ao conteúdo ético do processo têm aplicação precípua no âmbito probatório e induzem a exigência de determinados comportamentos colaborativos do Juiz com as partes e destas com aquele.

Essas constatações, somadas ao reconhecimento de que a prova não se produz apenas no interesse da parte, mas também do Poder Judiciário no esclarecimento dos fatos, nos faz reconhecer a existência de autênticos deveres do juiz e das partes em matéria de prova. É o que passaremos a demonstrar no tópico seguinte deste capítulo.

\subsection{Visão tridimensional do denominado "direito à prova"}

\subsection{1. Ônus das partes}

Como já se disse anteriormente, à exceção das causas que versam questões puramente de direito, nos litígios envolvendo questões fáticas controvertidas entre as partes, o juiz deve resolvê-las através da mediação de provas.

Isso porque, de um lado, o juiz, em regra, não tem conhecimento pessoal e direto dos acontecimentos que deram origem à demanda e, de outro, ainda que o tenha, lhe é vedado valer-se de conhecimento privado para o julgamento da causa, devendo embasar a decisão no conjunto probatório coligido aos autos.

\footnotetext{
${ }^{120}$ CRESCI SOBRINHO, Elicio de. Contribuição ao estudo do dever de veracidade das partes, no processo civil, cit.
} 
Além disso, é das partes o interesse primário na comprovação dos fatos alegados em juízo, a fim de convencer o juiz dos pressuspostos fáticos dos efeitos jurídicos por elas pretendidos, sob pena de sucumbirem ${ }^{121}$.

Assim, na visão tradicional da doutrina, a prova constituiria um típico ônus dos sujeitos parciais do processo, cuja não observância traria prejuízo processual ao sujeito onerado (insucesso na demonstração em juízo do direito alegado). Isso porque, pela regra clássica, quem alega determinado fato em juízo tem o ônus de comprová-lo, já que alegar e não provar é o mesmo que não alegar ${ }^{122}$.

O ônus da prova é tratado pela doutrina em uma dupla perspectiva: subjetiva e objetiva. Sob a primeira, já anunciada acima, o ônus da prova está diretamente associado à conduta processual das partes e ao seu interesse em municiar o juiz de elementos para reconhecimento dos fatos relevantes que embasam sua pretensão. Trata-se, sob esse viés, de verdadeira norma de conduta para os litigantes, sinalizando quais fatos, dentre aqueles que integram o thema probandi, deverão ser provados a fim de obterem decisão favorável à sua pretensão ou defesa.

Arruda Alvim" destaca que "as regras do ônus da prova destinam-se aos litigantes do ponto de vista de como devem se comportar, à luz das expectativas (ônus) que o processo lhes enseja, por causa da atividade probatória”.

Também Barbosa Moreira ressalta que o desejo de obter a vitória cria para o litigante "a necessidade, antes de mais nada, de pesar os meios de que se poderá valer no trabalho de persuasão, e de esforçar-se, depois, para que os tais meios sejam efetivamente utilizados na instrução da causa" ${ }^{124}$.

Sob a perspectiva subjetiva, pois, a prova constitui verdadeiro encargo instituído no interesse da própria parte, que tem a liberdade de produzi-la. Não o fazendo, não pratica ato ilícito, não lhe podendo ser exigida a conduta, quer pelo juiz ou pela parte contrária, mas se sujeita às consequências desfavoráveis de sua inércia. Daí porque Cambi, apoiado

\footnotetext{
${ }^{121}$ PACÍFICO, Luiz Eduardo Boaventura. O ônus da prova no direito processual. 1998. Dissertação (Mestrado) - Faculdade de Direito, Universidade de São Paulo, São Paulo, 1998. p. 168.

${ }^{122}$ YARSHELL, Flávio Luiz. Antecipação da prova sem o requisito da urgência e direito autônomo à prova. cit., p. 47.

${ }^{123}$ ARRUDA ALVIM, José Manoel de. Manual de direito processual civil. 6. ed. São Paulo: Ed. Revista dos Tribunais, 1995. v. 2, p. 429.

${ }^{124}$ BARBOSA MOREIRA, José Carlos. Julgamento e ônus da prova. In: processual: segunda série. São Paulo: Saraiva, 1988. p. 74. 
na lição de Echandia, afirma que "em suma, o ônus da prova não determina quem deve produzir a prova, mas quem assume o risco pela sua não-produção”. ${ }^{125}$

É certo, no entanto, que o princípio da comunhão das provas ou da aquisição processual ameniza a imediata correlação entre a atividade processual das partes e o resultado do processo, dado que mesmo a parte onerada pode acabar beneficiada pelo resultado da prova trazida pela parte contrária ${ }^{126}$.

Em outras palavras, segundo Micheli ${ }^{127}$, a atividade probatória das partes é apenas mediatamente ligada ao resultado favorável de uma delas e, reciprocamente, a sua inatividade é somente causa mediata do resultado desfavorável.

O princípio da aquisição ou comunhão da prova é corolário da natureza pública do processo e da unidade processual, e determina que as provas não têm titular, ou seja, uma vez aportadas ao processo, deverão ser analisadas independentemente do responsável por sua produção, podendo, inclusive, levar a consequências desfavoráveis à parte que a produziu, como é o caso de uma testemunha prestar depoimento desfavorável àquele que a arrolou, da prova pericial redundar resultado contrário àquele que a requereu ou mesmo de a prova produzida por um dos litisconsortes beneficiar o outro, revel, que com ele tenha interesses comuns, o que, aliás, está em consonância com a regra prevista no artigo 320, inciso I, do CPC.

Esse aspecto, portanto, diferencia o ônus da prova da categoria do ônus em sentido geral, já que seu simples cumprimento não assegura, necessariamente, uma consequência favorável à parte que a produziu, ou seja, a satisfação de seus interesses, mas apenas aumenta as chances de êxito na demonstração de seu pretenso direito ${ }^{128}$. De fato, para que

\footnotetext{
${ }^{125}$ CAMBI, Eduardo. A prova civil: admissibilidade e relevância, São Paulo: Ed. Revista dos Tribunais, 2006., p. 320.

${ }^{126}$ Por essa razão, Barbosa Moreira refere-se a uma "relevância mais psicológica do que jurídica", em termos práticos, ao ônus da prova subjetivo, pois "o órgão judicial só tem de preocupar-se, a rigor, com o aspecto objetivo do ônus da prova, não com o seu aspecto subjetivo" Julgamento e ônus da prova BARBOSA MOREIRA, José Carlos. Julgamento e ônus da prova, cit., p. 75.

${ }^{127}$ MICHELI, Gian Antonio. L'onere della prova. Padova: CEDAM, 1966. p. 108.

${ }^{128} \mathrm{Cf}$. Cintra, Grinover e Dinamarco esse ônus consiste na "necessidade de provar, em que se encontra cada uma das partes, para possivelmente vencer a causa” (in GRINOVER, Ada Pellegrini; CINTRA, Antônio Carlos de Araújo; DINAMARCO, Cândido Rangel. Teoria geral do processo. 25. ed. São Paulo: Malheiros Ed., 2009. no 228, p. 312) e também Marinoni e Arenhart: "Isso indica, com clareza, que a produção de prova não é um comportamento necessário para um julgamento favorável - ou para o resultado favorável. Na verdade, o ônus da prova indica que a parte que não pretende produzir prova se sujeitará ao risco de um resultado desfavorável, ou seja, o descumprimento do ônus não implica, necessariamente, um resultado desfavorável, mas o aumento do risco de um julgamento contrário, uma vez que, como precisamente adverte Patti 'una certa percentuale di rischio sussiste anche per la parte che ha fornito la prova."” (MARINONI, Luiz Guilherme; ARENHART, Sérgio Cruz. Prova, cit., p. 165).
} 
a prova traga efetivo benefício à parte que a produz é necessário que tenha força persuasiva suficiente a ensejar o acolhimento de sua pretensão, considerando-se os demais elementos dos autos e todo o conjunto probatório produzido ${ }^{129}$.

Trata-se, portanto, de um ônus imperfeito ${ }^{130}$, já que sua não desoneração pela parte pode ser suprida pela parte contrária, encartando aos autos provas que lhe sejam desfavoráveis, ou até mesmo pela atividade instrutória do juiz, o que atenua o rigor do aspecto subjetivo do ônus da prova, como se verá no item subsequente.

Até aqui se tratou do ônus da prova sob o prisma subjetivo. Já sob o aspecto objetivo - tido para maior parte da doutrina como seu aspecto essencial - o ônus da prova está diretamente ligado à atividade jurisdicional, em especial à necessidade de o juiz proferir decisão mesmo que não convencido acerca dos fatos relevantes e controvertidos.

Como já se disse, hipóteses há em que, seja porque a parte onerada não produziu qualquer prova, seja porque, tendo o feito, não conseguiu alcançar o convencimento do juiz, o que também não foi suprido pela parte contrária ou mesmo pela atividade instrutória do próprio juiz, fato é que este se coloca diante da necessidade de proferir julgamento ainda em estado de dúvida quanto à matéria controvertida entre as partes.

Nesse sentido, diante do dever funcional do juiz de proferir decisão e da proibição do pronunciamento do non liquet, o juiz, valendo-se da distribuição legal do ônus da prova como regra de julgamento, deve julgar desfavoravelmente àquele a quem por lei incumbia sua produção.

O ônus da prova em sentido objetivo consiste, pois, no critério legal e objetivo a ser seguido pelo juiz para a prolação da sentença diante da ausência ou insuficiência da prova, hipótese em que é atribuída a uma das partes a consequência desfavorável da lacuna probatória.

Do contrário, sem o necessário convencimento judicial e sem um critério legal para a solução da controvérsia, dar-se-ia ensejo à verdadeira denegação de justiça, em arrepio à garantia constitucional na inafastabilidade do controle jurisdicional (art. 5 $, \mathrm{XXXV}, \mathrm{CF}$ ),

\footnotetext{
${ }^{129}$ A esse respeito v., CAMBI, Eduardo. A prova civil: admissibilidade e relevância, cit., p. 314, que completa: "Isso, em contrapartida, não retira a importância do ônus da prova, porque, se o seu cumprimento não garante automaticamente a obtenção da tutela jurisdicional favorável, com certeza sua não observância aumenta o risco de uma decisão desfavorável. Com efeito, a consequência negativa que pode derivar da inércia da parte, a quem incumbe o ônus da prova, não é necessária, mas, em geral, mais provável, já que quem produz a prova tem mais chance de influir no convencimento do juiz."

${ }^{130}$ Cfr. VERDE, Giovanni. L'onere dela prova nel processo civile. Napoli: Jovene, 1974. p.11.
} 
ou, o que poderia ser ainda mais nefasto, à prolação de sentença embasada em puro arbítrio judicial.

Com efeito, conforme reconhecido por Yarshell ${ }^{131}$, o ônus da prova visto como regra de julgamento constitui verdadeira garantia contra o arbítrio, já que a lei estabelece um parâmetro racional e objetivo para o julgamento diante do estado de ignorância do julgador a respeito dos fatos.

E, conforme completa Cambi ${ }^{132}$, com apoio nas lições de Carnelutti, apesar de a aplicação das regras de distribuição do ônus da prova não privilegiar, necessariamente, a justiça da decisão, porque o fato de a parte não ter oferecido as provas necessárias para comprovar as suas alegações não significa não serem suas afirmações verdadeiras, por outro lado, a solução adotada pela lei processual também não é arbitrária, porque é embasada em uma máxima da experiência, a qual considera dever a parte, que tem interesse em convencer o juiz de que tem razão, provar aquilo que alega.

Micheli ${ }^{133}$ salienta que esse aspecto objetivo do fenômeno teria sido percebido, em primeiro lugar, no processo austríaco, no qual os poderes de iniciativa probatória do juiz preponderam sobre os das partes ${ }^{134}$. Para o processualista, tido como o responsável pela formulação do conceito de ônus da prova como regra de julgamento ${ }^{135}$, a importância do ônus da prova sob o aspecto subjetivo estaria limitada ao exame da legitimidade do exercício do poder probatório das partes.

Em nosso sentir, em que pese a preponderância, na doutrina atual, do aspecto objetivo do ônus da prova, não se pode aniliquilar a importância do seu prisma subjetivo. Trata-se da mesma realidade, com facetas diferentes, uma voltada para a atividade das partes, impondo consequências processuais desfavoráveis à sua inércia, e outra dirigida ao

\footnotetext{
${ }^{131}$ YARSHELL, Flávio Luiz. Antecipação da prova sem o requisito da urgência e direito autônomo à prova. cit., p. 57.

${ }^{132}$ CAMBI, Eduardo. A prova civil: admissibilidade e relevância, cit., p. 330-331.

${ }^{133}$ MICHELI, Gian Antonio. L'onere della prova, cit., 1966.

${ }^{134}$ Parte da doutrina, inclusive nacional, chega mesmo a afirmar a existência tão-somente do aspecto objetivo do ônus da prova. Nesse sentido Pontes de Miranda asseverava: "O ônus da prova é objetivo, não subjetivo. Como partes, sujeitos da relação processual, todos os figurantes hão de provar, inclusive quanto a negações. Uma vez que todos têm de provar, não há discriminação subjetiva do ônus da prova. O ônus da prova, objetivo, regula a consequência de se não haver produzido prova. Em verdade, as regras sobre as consequências da falta da prova exaurem a teoria do ônus da prova. Se falta prova, é que se tem de pensar em se determinar em quem se carga a prova. O problema da carga ou do ônus da prova é, portanto, o de determinar-se a quem vão as consequências de se não haver provado." (PONTES DE MIRANDA, Francisco Cavalcanti. Comentários ao Código de Processo Civil. Rio de Janeiro: Forense, 1974. t. 6, p. 270-271).

${ }^{135}$ SANTÍS MELENDO, Santiago. La prueba, los grandes temas de derecho probatório, cit., p. 126.
} 
juiz, ambas as visões consentâneas com a natureza pública do processo e predispostas ao alcance de suas finalidades, o que será retomado adiante.

Seja como for, fato é que o ônus carreado às partes é apenas um dos aspectos da prova. Até mesmo porque as regras de distribuição do ônus da prova devem ser aplicadas subsidiariamente, não anulando nem mesmo mitigando, em qualquer medida, nem os poderes instrutórios do juiz, nem o direito (ou poder) probatório da parte. É o que se passará a tratar a seguir.

\subsubsection{Poder instrutório do juiz e direito (ou poder) probatório das partes}

A prova, no direito processual contemporâneo, também é entendida como poder do juiz, sendo certo que a crescente aceitação e ampliação dos poderes instrutórios do juiz põe em xeque o papel e a importância do ônus da prova, especialmente sob o ângulo subjetivo.

De fato, em uma análise clássica das regras de distribuição do ônus da prova, o juiz se comportaria como mero espectador da atividade processual das partes, reservando-se a analisar o resultado da atividade probatória por elas desenvolvida no processo para então decidir de acordo com esses elementos ${ }^{136}$.

No entanto, a evolução da ciência processual e, em especial, os influxos da visão publicista do processo civil têm conferido papel mais ativo ao juiz na direção e, notadamente, na instrução do processo, conferindo uma interpretação mais abrangente do disposto no artigo 130 do CPC, de modo a possibilitar ao juiz a determinação, de ofício, das provas que entender necessárias à instrução do processo, permanecendo o debate apenas no que se refere à subsidiariedade ou concomitância dos poderes instrutórios do juiz.

A Lei 9.099/95, ao disciplinar o procedimento das ações ajuizadas perante os Juizados Especiais Cíveis e Criminais, é ainda mais explícita ao determinar, em seu artigo $5^{\circ}$, que "o juiz dirigirá o processo com liberdade para determinar as provas a serem

\footnotetext{
${ }^{136}$ Barbosa Moreira assevera que até certo tempo "na órbita judiciária, se queria o juiz inerte em seu pedestal, espectador frio e distante do duelo entre as partes e privado de qualquer possibilidade de tomar suas próprias iniciativas no sentido de averiguação da verdade.” BARBOSA MOREIRA, José Carlos. O juiz e a prova. In: Temas de direito processual: segunda série. São Paulo: Saraiva, 1988. p. 179.
} 
produzidas, para apreciá-las e dar especial valor às regras da experiência comum e técnica.”.

Bedaque $^{137}$ destaca, nesse sentido, que muitas vezes a tão só iniciativa probatória das partes é insuficiente, o que induz o juiz a se comportar ativamente. Isso porque quanto maior a coincidência entre a reconstituição dos fatos e aqueles originalmente ocorridos, mais as chances de sobrevir um julgamento justo, de acordo com a ordem jurídica existente, o que constitui um dos escopos da jurisdição.

Também nessa linha de entendimento, Barbosa Moreira destaca que diante do non liquet, ao invés de aplicar imediatamente as regras sobre distribuição do ônus da prova, o juiz pode e deve determinar atividades probatórias destinadas a esclarecer os fatos. Nesse sentido:

\begin{abstract}
"Julgar segundo as regras de distribuição do ônus não é atitude que tranquilize de todo o juiz consciente de sua responsabilidade: ele atira no escuro, pode acertar o alvo, mas pode igualmente errar, e sua sentença, injusta, produzirá na vida dos litigantes efeitos diversos do querido pelo ordenamento, quando não diametralmente opostos" ${ }^{\text {"138 }}$.
\end{abstract}

De fato, à medida que se reconhece que o resultado da atividade probatória no processo é de inegável interesse também do Estado-juiz, reforça-se o questionamento da ideia de prova tão-somente como ônus da parte, o que justificaria a passividade do juiz diante da instrução probatória. Nesse sentido se posiciona Yarshell ${ }^{139}$ :

\begin{abstract}
"a qualificação da prova como um ônus - se entendido como imperativo do próprio interesse - parece mesmo ser imperfeita ou, quando menos, insuficiente diante da premissa de que no processo a descoberta da verdade atende não apenas ao interesse da parte, mas também ao interesse do Estado que presta a jurisdição. A verdade proporcionada pela prova ainda que se traduza, nos limites do possível, em um juízo de verossimilhança e probabilidade - é instrumento para edição de decisões justas e, em alguma medida, contribui para a segurança jurídica. Vale dizer: a prova se apresenta não apenas como instrumento para o êxito da parte em juízo, mas, em boa medida, como elemento apto à consecução dos escopos jurídico e social do processo."
\end{abstract}

Gomes reforça o argumento ao defender que, no Estado Democrático e Social de Direito, que assume o objetivo de promover o bem-estar social, o processo deve também

\footnotetext{
${ }^{137}$ BEDAQUE, José Roberto dos Santos. Poderes instrutórios do juiz, cit., p. 125.

${ }^{138}$ BARBOSA MOREIRA, José Carlos. O neoprivatismo no processo civil, cit., p. 95.

${ }^{139}$ YARSHELL, Flávio Luiz. Antecipação da prova sem o requisito da urgência e direito autônomo à prova. cit., p. 149.
} 
refletir os valores e os princípios que o norteiam, assumidos nas normas constitucionais. Por essa razão, o Estado outorga ao magistrado poderes de direção do processo, nele devendo participar ativamente, o que se mostra ainda mais relevante por ocasião da instrução, já que as provas coligidas servirão de base para que, à luz da persuasão racional, seja proferida a decisão, que deve aplicar da melhor forma o direito ${ }^{140}$.

Amendoeira Júnior ${ }^{141}$, por sua vez, pondera que, numa visão cada vez mais publicista do processo civil, cabe ao juiz buscar equilibrar eventuais diferenças entre as partes, esmerando-se em instruir a causa de forma a dar primazia à busca da verdade, dialogando com as partes no curso de todo o processo, o que lhe permitirá formar seu conhecimento de maneira efetiva e entregar realmente uma tutela justa, efetiva e tempestiva.

Nessa ordem de idéias, a doutrina atual tende a conferir maior importância ao aspecto objetivo que ao subjetivo do ônus da prova. Isso porque, reconhecendo-se poderes instrutórios ao juiz, de forma concorrente ou subsidiária à atividade das partes, há mitigação da necessidade das partes de provarem os fatos que lhe beneficiem. A atividade instrutória do juiz, portanto, soma-se ao princípio da comunhão da prova para justificar a relação de mediatidade entre a atividade probatória das partes e o resultado favorável do processo.

Todavia, não se pode afirmar o absoluto afastamento do aspecto subjetivo do ônus da prova, já que a atividade do juiz e das partes, nesse aspecto, são complementares, e não reciprocamente excludentes. Nesse sentido Barbosa Moreira ${ }^{142}$ afirma:

"a ampliação dos poderes do órgão judicial não tem como contrapartida
necessária o amesquinhamento do papel das partes, nem a eliminação, ou
sequer a redução, das garantias a que fazem jus, e tampouco da
responsabilidade que sobre elas pesa. (...) Em matéria de prova, enfim,
devia ser claro que nenhuma intensificação da atividade oficial, por mais
'ousada' que se mostre, tornará dispensável, ou mesmo secundária, a
iniciativa dos litigantes. O papel do juiz e o das partes são aqui
complementares; absurdo concebê-los como reciprocamente excludentes.

140“"Aí reside a grande diferença entre o papel do juiz no Estado liberal, do século passado e o que dele se espera atualmente. Hoje o Estado promete atuação ativa na realização do bem-estar social. Lá e aqui os princípios fundamentais do processo são muito diversos, exatamente porque diversos são os do próprio Estado. A passividade deste refletia na função jurisdicional. Tal fator somado à concepção privatística do processo não poderia produzir figura diversa daquela do juiz passivo." GOMES, Sérgio Alves. Os poderes do juiz na direção e instrução do processo civil. Rio de Janeiro: Forense, 1997. p. 244.

${ }^{141}$ AMENDOEIRA JUNIOR, Sidnei. Poderes do juiz e tutela jurisdicional: a utilização racional dos poderes do juiz como forma de obtenção da tutela jurisdicional efetiva, justa e tempestiva. São Paulo: Atlas, 2006, p. 3-4.

${ }^{142}$ BARBOSA MOREIRA, José Carlos. A função social do processo civil moderno e o papel do juiz e das partes na direção e instrução do processo, cit. 
E não custa reconhecer que, de fato, ao menos no comum dos casos, por óbvias razões, dos próprios litigantes é que se obterá, com toda a probabilidade, aporte mais substancioso".

Posicionando-se a respeito da questão, Bedaque defende que os poderes instrutórios do juiz não se subordinam às regras de ônus da prova e não as afetam, visto que são problemas a serem resolvidos em momentos diversos. Para o professor, o ônus da prova destina-se a conferir meio de proferir decisão quando os fatos não restarem suficientemente provados. Antes disso, todavia, deve o juiz esgotar todos os meios possíveis de reconstituição dos fatos. Ou seja, o juiz somente deve se socorrer das regras de distribuição do ônus probatório para proferir a sentença quando frustrada a atividade probatória das partes e do próprio magistrado ${ }^{143}$.

Em apoio a essa mesma idéia, Gomes se manifesta no sentido de que o juiz não deve aplicar, de pronto, a regra do ônus da prova "quando verifica a possibilidade de descobrir a verdade por outros meios de prova não requeridos pela parte” ${ }^{144}$.

Além disso, como já visto, o pensamento contemporâneo do direito processual civil exige o permanente diálogo judiciário, a colaboração e a lealdade entre as pessoas que participam do processo. E esse modelo de processo corresponde, na fase instrutória, a uma "busca coletiva" pelo esclarecimento dos fatos ${ }^{145}$, o que força concluir que as regras de distribuição legal do ônus da prova não devem servir de liberação ao sujeito integrante do outro pólo ou mesmo do próprio Estado-Juiz.

Falou-se até aqui dos poderes instrutórios do juiz. No entanto, como já se acenou no subitem 2.1, a prova também é entendida como um direito (ou poder) das partes (sujeitos parciais), assegurado constitucionalmente.

A Constituição Federal brasileira, ao assegurar o acesso à justiça, garante também aos jurisdicionados o pleno exercício do contraditório e da ampla defesa, integrantes do devido processo constitucional (art. $5^{\circ}, \mathrm{LV}, \mathrm{CF}$ ). Estes, por sua vez, devem ser entendidos

\footnotetext{
143“'Assim, não deve o julgador, diante de um resultado insuficiente da instrução da causa, recorrer imediatamente às regras sobre o ônus da prova. Se verificar a possibilidade de esclarecer algum fato, mediante a realização de determinada prova, não pode se omitir. Somente esse comportamento do magistrado pode impedir que o processo se transforme em mais um instrumento de injustiça. E, para esse efeito, não tem relevância a natureza da relação jurídica controvertida.” BEDAQUE, José Roberto dos Santos. Poderes instrutórios do juiz, cit., p. 125.

${ }^{144}$ GOMES, Sérgio Alves. Os poderes do juiz na direção e instrução do processo civil, cit., p. 258.

${ }^{145}$ FERREIRA, William dos Santos. Princípios fundamentais da prova cível, cit.
} 
como o direito das partes de participar do desenvolvimento e do resultado do processo, ou seja, de influir na formação do convencimento do juiz.

Com efeito, é entendimento praticamente unânime da doutrina atual que o direito de ação abarca uma série extensa de faculdades cujo exercício se considera necessário, em princípio, para garantir a correta e eficaz prestação da jurisdição, dentre as quais se sobressai o chamado "direito à prova"146.

Elucidativas as considerações de Grinover a esse respeito ${ }^{147}$ :

"E não é em vão que se salienta o direito à prova no quadro das garantias da ação e da defesa. Já se notou que a atividade probatória representa indubitavelmente o momento central do processo: estritamente ligada à alegação e indicação dos fatos, visa ela a possibilitar a demonstração da verdade, revestindo-se, portanto, de fundamental importância para o conteúdo do provimento jurisdicional."

Assim, aquele que alega determinados fatos em juízo para deles extrair dada consequência jurídica, ou então aquele que se defende da predita pretensão, tem direito a produzir e ter valoradas as provas necessárias à confirmação da juridicidade de sua pretensão ou de sua resistência. Sobre o tema, Yarshell esclarece ${ }^{148}$ :

\begin{abstract}
"Assim, enquanto a ação - ressalva feita as suas diferentes concepções pode ser entendida como direito de invocar do Estado um provimento jurisdicional e a defesa como o direito do demandado de ter levadas em consideração suas alegações, o direito à prova tem sido concebido, de um lado, como o direito de empregar todos os meios disponíveis a fim de se demonstrar a verdade dos fatos em que fundada uma pretensão ou resistência; e, de outro, como o direito de influir sobre a formação do convencimento do juiz a propósito dos fatos, através de todos os meios, diretos e contrários, de que se disponha."
\end{abstract}

O processualista, aliás, ao defender a existência de um direito autônomo à prova, sem vinculação direta e necessária com a declaração do direito pelo juiz, faz interessante distinção entre os conceitos de "direito de provar" e "direito à prova”.

\footnotetext{
146،“A garantia constitucional da ação tem como objeto o direito ao processo, assegurando às partes não só a resposta do Estado, mas ainda o direito de sustentar suas razões, o direito ao contraditório, o direito de influir sobre a formação do convencimento do juiz." (BARBOSA MOREIRA, José Carlos. A Constituição e as provas ilicitamente obtidas, cit.).

${ }^{147}$ GRINOVER, Ada Pellegrini. O conteúdo da garantia do contraditório. In: Novas tendências do direito processual de acordo com a Constituição de 1998. Rio de Janeiro: Forense Universitária, 2001. p. 19.

${ }^{148}$ YARSHELL, Flávio Luiz. Antecipação da prova sem o requisito da urgência e direito autônomo à prova, cit., p. 209.
} 
O chamado "direito de provar", coincidente com o que denominamos de "direito à prova" no presente estudo, é desdobramento do direito de ação e de defesa, e consiste no direito de empregar todos os meios disponíveis para a demonstração da verdade dos fatos em que fundada uma pretensão ou resistência, no contexto de um dado processo cujo objeto é a declaração do direito. Compreende, portanto, o direito de atuar concretamente para a formação do convencimento do juiz a propósito dos fatos, estando nele abrangidos o direito de requerimento, admissão, produção e valoração da prova em juízo.

Por outro lado, o "direito à prova”, a que se refere Yarshell, não constitui mero desdobramento do direito de invocar a tutela jurisdicional. Trata-se, isto sim, de um direito simplesmente à produção (obtenção e pré-constituição) de determinada prova, entendido como prerrogativa de invocar do Estado um ato que se esgote aí (direito de buscar e ter acesso à prova), desvinculado, portanto, de um processo preexistente que vise à declaração de um direito.

Como claramente se verifica, portanto, a qualificação negativa da prova como ônus - imperativo do próprio interesse - parece mesmo insuficiente para explicar sua dimensão positiva, decorrente das garantias constitucionais de acesso à justiça, contraditório e devido processo legal a que anteriormente aludimos.

E, no contexto das posições que emergem da relação jurídica processual, ao direito à prova de que são titulares os sujeitos parciais (ou ao poder de produzi-las), corresponde o dever do Estado-Juiz de garantir a ampla produção, o debate e a valoração jurídica das provas sobre os fatos pertinentes e relevantes para o julgamento.

Nesse sentido, aliás, Marinoni e Arenhart ${ }^{149}$ fazem importante observação no sentido de que o ônus e o direito (ou poder), nesse caso, não se chocam, eis que o ônus tem a ver com as consequências processuais do comportamento da parte, enquanto o direito se dirige contra o Estado, que não pode negar o direito das partes de produzir a prova.

Acrescentam, ainda, que o direito à prova é de titularidade tanto da parte onerada quanto daquela destituída do ônus probatório e que, ao menos em linha de princípio, apenas deve requerer a produção da contraprova quando temer que a parte onerada possa influir sobre o convencimento do juiz. Nesse sentido, o direito à prova impede o juiz de negar a produção de uma prova que possa influir sobre seu convencimento, ainda que seja requerida pela parte que não tem o ônus da prova.

\footnotetext{
${ }^{149}$ MARINONI, Luiz Guilherme; ARENHART, Sérgio Cruz. Prova, cit., p. 173.
} 
Analisada, assim, a prova sob seu o viés positivo, cumpre agora nos dedicarmos ao dever de colaboração e sua imbricação com o tratamento jurídico da prova.

\subsubsection{Dever de colaboração para a elucidação dos fatos}

Há ainda um último aspecto, de especial interesse para o nosso estudo e essencialmente relacionado à prova, consistente no dever geral de colaboração com o Poder Judiciário para a elucidação dos fatos.

Esse dever, que tem previsão expressa no ordenamento processual brasileiro, ex vi do artigo 339 do CPC, guarda, por sua vez, relação estreita com o viés publicista do processo e os pressupostos teóricos do chamado "processo cooperativo", ambos anteriormente estudados, e também com o conteúdo ético do processo, que será abordado no capítulo seguinte.

Como já se disse, se o ônus se caracteriza como uma liberdade de conduta cuja não observância acarreta consequências negativas apenas à parte onerada, já se verifica, desde logo, a sua insuficiência para a qualificação jurídica da prova. Isto se dá especialmente no ambiente de um processo reconhecidamente publicista, já que a lacuna ou a insuficiência probatória, além de prejudicar o êxito da pretensão da parte, também resulta, no mais das vezes, em prejuízo ao interesse público presente no processo.

Nesse sentido, se o resultado da prova produzida no processo é, conforme já dito e repisado, não apenas de interesse da parte, mas também de inegável interesse do EstadoJuiz, poderia se afirmar então a existência de autênticos deveres dos sujeitos processuais em matéria de prova? Afinal, qual o significado da regra legal de colaboração descrita no artigo 339 do CPC?

Em outras palavras, para além do direito (ou poder) probatório constitucionalmente assegurado às partes e dos poderes instrutórios do juiz, e também em razão deste último, poderia se afirmar a existência de um verdadeiro dever de colaboração das partes no âmbito probatório? Em caso positivo, qual seu conteúdo e extensão no processo civil brasileiro?

Em que pesem as dificuldades que cercam o estudo da questão, que não são poucas, em nosso entender a resposta é positiva, sendo certo que o alcance e as limitações desse 
dever - que é tanto das partes, como também do juiz, e mais, de todo aquele que participa do processo - será explicitado nos Capítulos 5 e 6 de nosso estudo.

Por ora, cumpre, desde logo, consignar que a doutrina tradicional, tanto nacional como estrangeira, sempre pareceu refratária à ideia de que a produção da prova pudesse ser tida como um dever da parte, de modo que a sua não observância pudesse acarretar a imposição de sanção ${ }^{150}$. Essa doutrina parte de uma perspectiva liberal do processo para afirmar que esse dever seria incompatível com o princípio dispositivo.

Aliás, como registram Cintra, Grinover e Dinamarco, parte da doutrina mais tradicional manifesta-se, inclusive, abertamente contrária ao princípio da lealdade no processo civil, por considerá-lo inquisitivo, contrário à livre disponibilidade da parte e até mesmo "instrumento de tortura moral"

Todavia, como ensina Yarshell, diante do influxo publicista e da ênfase dada mais recentemente ao conteúdo ético do processo, o tema da prova - embora sem se desconectar do ônus - acabou se conectando, no âmbito doutrinário e mesmo em alguns sistemas legislativos, também à ideia de dever, que ora se apresenta como um "dever de colaboração" ou de "cooperação", ora se revela mesmo como um verdadeiro "dever de veracidade" atribuído às partes. E, essa ideia de dever no âmbito probatório se associa ao princípio de lealdade, probidade e moralidade, regulador da conduta não apenas das partes, mas de todos os sujeitos da relação jurídica processual, cuja violação caracteriza abuso do direito processual e litigância de má-fé, ensejando sanções ${ }^{152}$.

No ordenamento processual civil brasileiro, é fato conhecido que as reformas processuais havidas nos últimos anos, em sua grande maioria, trataram de robustecer o aspecto ético do processo, impondo uma série de deveres comportamentais às partes e seus procuradores, e reforçando as sanções decorrentes de sua inobservância. E, dentre os deveres impostos aos sujeitos processuais, previstos no artigo 14 do CPC, destacam-se,

\footnotetext{
${ }^{150}$ Nesse sentido: CHIOVENDA, Giuseppe. Instituições de direito processual civil. Trad. Paolo Capitanio; com anotações Enrico Tullio Liebman. 2. ed. Campinas: Bookseller, 2000. v. 2, p. 374; CARNELUTTI, Francesco. Sistema di diritto processuale civile, cit., v. 1, p. 53 e ss; CAMBI, Eduardo. A prova civil: admissibilidade e relevância, cit., p. 320; entre outros.

${ }^{151}$ GRINOVER, Ada Pellegrini; CINTRA, Antônio Carlos de Araújo; DINAMARCO, Cândido Rangel. Teoria geral do processo, cit., p. 78.

${ }^{152}$ YARSHELL, Flávio Luiz. Antecipação da prova sem o requisito da urgência e direito autônomo à prova, cit., p. 150. O autor ainda prossegue em seu pensamento afirmando que essa mesma ênfase ao conteúdo ético do processo inspirou em grande medida a recente reformulação teórica das regras de distribuição do ônus da prova, denominada de "cargas dinâmicas", que a atribui a quem tem melhores condições substanciais de obtenção e produção, considerando-se a posição dos litigantes e o acesso às provas relevantes.
} 
especialmente, o de "expor os fatos em juízo conforme a verdade" (inciso I), "não formular pretensões, nem alegar defesa, cientes de que são destituídas de fundamento” (inciso III) e “não produzir provas, nem praticar atos inúteis ou desnecessários à declaração ou defesa do direito" (inciso IV).

Ou seja, no que se refere especificamente às partes, embora claramente imbuídas do objetivo de convencer o juiz de suas alegações com vistas a obter êxito, os deveres de colaboração, lealdade e probidade as obriga a apresentar os fatos em juízo conforme a verdade, bem ainda a se portarem de forma a cooperar com o Estado-Juiz na solução da lide.

A dificuldade reside em identificar, justamente, o conteúdo e alcance do dever de colaboração no que se refere à instrução probatória, considerando-se a amplitude do direito de defesa assegurado constitucionalmente aos litigantes. Ou seja, em matéria de prova, qual o alcance do dever de colaboração fixado às partes e quando se pode ter caracterizado o abuso do direito e aplicadas eventuais sanções pela litigância de má-fé? Até onde se pode exigir das partes que tragam aos autos alegações e provas que eventualmente desprestigiem sua própria tese defendida no processo? Essas questões serão enfrentadas nos capítulos seguintes deste estudo.

Por ora, tomando como pontos de partida a instrumentalidade, o viés publicista e, ainda, as premisssas teóricas e as bases constitucionais do denominado "processo cooperativo", o que podemos desde logo afirmar, com base em prestigiosa doutrina, é que o comando do artigo 339 do CPC não constitui mera exortação para as partes e terceiros, nem tem mero conteúdo ético ou moral. Nas palavras de Marinoni e Arenhart:

"a ratio essendi dessa previsão é evidente: se o Estado deve solucionar o
conflito de interesses com a finalidade de aplicar o direito - sendo esse,
também, o objetivo último do Estado-jurisdição -, a coletividade deve
ministrar meios (de forma mais completa possível) para que a decisão
jurisdicional seja a mais adequada. Daí resulta que o dever de
colaboração é inerente ao monopólio da jurisdição. Demais disso, não há
como esquecer que esse dever decorre do dever geral de sujeição ao
poder do Estado. Afinal, se todos estão submetidos ao poder estatal,
igualmente estão subjugados pela jurisdição, de forma a estarem
constrangidos a colaborar com o Estado para a 'descoberta da
verdade" 153 a

${ }^{153}$ MARINONI, Luiz Guilherme; ARENHART, Sérgio Cruz. Prova, cit., p. 151. 
Até mesmo porque, como já se ressaltou, num processo de cunho publicista e direcionado a uma postura mais cooperativa entre seus sujeitos, a instrução probatória é entendida como fase de "busca coletiva" pelo esclarecimento dos fatos, sendo a regra legal de distribuição do ônus da prova caminho subsidiário, a ser utilizado apenas quando frustrada a atividade probatória das partes e do magistrado, não servindo simplesmente de liberação aos sujeitos processuais ou mesmo ao próprio Estado-Juiz de seus respectivos ônus e deveres.

Investigando de forma aprofundada o assunto, Yarshell lembra que, nos processos civis que versam sobre direitos indisponíveis, a superação da falta de colaboração de qualquer das partes no esclarecimento dos fatos não se pode dar mediante o recurso à eficaz técnica da confissão ficta, ligada ao conceito de ônus, e que pode ser empregada diante da ausência de contestação (revelia), recusa ao depoimento pessoal, recusa à exibição de documentos, dentre outros exemplos. Nesses casos, citando as lições de Marinoni e Arenhart, Yarshell admite o emprego de medidas coercitivas ou mesmo de subrogação contra as partes ou mesmo terceiros, a fim de suprir sua falta de colaboração, o que parece confirmar a existência de autênticos deveres das partes em matéria de prova ${ }^{154}$.

Yarshell, ainda, ao defender a possibilidade de antecipação da prova, no processo civil brasileiro sem o requisito da urgência, traz importantes reflexões no que se refere à correlação existente entre o dever de colaboração (e, especialmente, o dever de veracidade) e o momento de constituição da prova.

Nesse sentido, destaca que na perspectiva dos sistemas de civil law, que não prestigiam a formação da prova de maneira antecipada, reservando-a para a fase porsterior de instrução, carece de maior respaldo jurídico e ético exigir das partes um dever de veracidade sob o prisma objetivo. Até mesmo porque entender contrariamente importaria reconhecer como litigante de má-fé todo aquele que sucumbisse no processo, o que é inadmissível.

Contrariamente, nos sistemas de common law, em que as partes figuram como protagonistas exclusivos na tarefa de propor e produzir provas, o dever de veracidade se impõe de forma direta às partes, notadamente em razão da exigência de produção antecipada das provas, com a apresentação de elementos na fase preliminar do discovery, no direito norte-americano, ou da disclosure, no direito inglês.

\footnotetext{
${ }^{154}$ YARSHELL, Flávio Luiz. Antecipação da prova sem o requisito da urgência e direito autônomo à prova, cit., p. 178.
} 
Com efeito, a discovery ou disclosure consistem em uma fase preliminar e extrajudicial de investigação e levantamento de provas (pre-trial), prevista nos países que adotam o sistema da common law, na qual as próprias partes, por seus advogados - e sem qualquer interferência ou participação do órgão judicial - realizam uma série de diligências para obtenção de provas e esclarecimento dos fatos controvertidos, visando a encontrar evidências, delimitar questões, evitar surpresas e perpetuar testemunhos para o futuro julgamento. E o resultado dessa produção antecipada de provas permite não apenas a fixação do objeto do litígio, como também orienta a estratégia processual das partes, podendo conduzir até mesmo a composição extrajudicial para pôr fim à controvérsia, eis que as partes já conhecem, de antemão, o arsenal probatório de que se valerá o órgão judicial para a solução do litígio ${ }^{155}$. Diante disso é que Yarshell defende que:

"a antecipação da prova ou mecanismos de instrução preliminares não
apenas permitem uma mais autêntica cooperação das partes como, ainda,
se revelam importante instrumento para combater o eventual abuso do
processo. Isso ocorre na medida em que se oferecem aos interessados
elementos a partir dos quais podem razoavelmente aferir suas chances de
êxito."156

Essas constatações, por outro lado, desmentem a ideia de que o dever de veracidade das partes e o de colaboração seriam incompatíveis com o princípio dispositivo, ou que teriam nascido sob a perspectiva de Estados totalitários e antiliberais, o que sempre motivou parcela da doutrina nacional e estrangeira a rejeitá-los. Nesse sentido:

"Nota-se, portanto - e não sem alguma perplexidade - que um sistema
dito liberal acaba sendo mais rigoroso em matéria ética do que os
sistemas que poderiam ser qualificados como intervencionistas de civil
law; que, embora preocupados em reforçar os poderes de instrução do
juiz, acabam talvez se descuidando do controle da conduta das partes. Em
boa medida, o modelo lá adotado parece ser ao menos coerente com a
idéia de respeito ao órgão judicial e as respectivas decisões judiciais, ali
superlativamente valorizadas"157.

${ }^{155}$ PITT, Gioconda Fianco. Dever de veracidade no processo civil brasileiro e sua relação com o instituto da Discovery no processo norte-americano da common law. In: KNIJNIK, Danilo; CARPES, Artur Thompsen (Coords.). Prova Judiciária: estudos sobre o novo direito probatório. Porto Alegre: Livr. do Advogado Ed., 2007. p. 121-126.

${ }^{156}$ YARSHELL, Flávio Luiz. Antecipação da prova sem o requisito da urgência e direito autônomo à prova, cit., p. 180.

${ }^{157}$ YARSHELL, Flávio Luiz. Antecipação da prova sem o requisito da urgência e direito autônomo à prova, cit., p. 184. 
Não obstante, mesmo no ordenamento jurídico brasileiro, que não adota como regra a possibilidade de produção antecipada de provas (reservando-a para as situações de urgência), o professor reconhece exemplos do dever de avaliação da prova pré-constituída, o que se insere nos deveres de veracidade e também de colaboração. São eles: a proibição da parte se contrapor à literalidade da prova, dando ensejo a eventual aplicação de sanções (artigo 14, incisos I e III e artigo 17, II, do CPC), a isenção de custas e honorários ao réu de ação monitória que der cumprimento ao mandado inicial, reconhecendo a existência da dívida diante do documento apresentado pelo autor (artigo 1.102-C, $\S 1^{\circ}$, do CPC) e, ainda, de forma análoga, a redução da verba honorária pela metade em caso de pagamento integral do débito, no prazo de 3 dias, nas execuções fundadas em título extrajudicial (artigo 652-A do CPC, inserido pela Lei 11.382/2006).

Pelo exposto, o que se pode concluir nesta fase de nosso estudo é que a existência de autênticos deveres em matéria de prova (como os de colaboração e de veracidade) guarda relação com o conteúdo ético do processo e com as bases teóricas e constitucionais do processo chamado cooperativo, deveres esses que se impõem não somente às partes e ao juiz, mas a todos aqueles que integram a relação jurídica processual.

Não se pode deixar de ponderar, por outro lado, que essa exigência não pode importar violação a outros relevantes valores constitucionais, essencialmente ligados ao Estado Democrático de Direito, como são o da liberdade, da privacidade, da intimidade, do sigilo, da dignidade da pessoa humana, dentre outros.

Nesse sentido, se não se pode exigir das partes a produção espontânea de provas contrárias a seus interesses, também não se pode deixar de reconhecer o dever das partes e também de terceiros de expor os fatos conforme a verdade e de portarem de forma a cooperar com o Estado Juiz na produção de toda e qualquer prova por ele reputada imprescindível à solução da lide (como é o caso de apresentação de documentos exigidos pelo juiz, submissão à perícia médica, etc.).

E, na inércia, o ordenamento jurídico autoriza a imposição de diversas espécies de sanções lato sensu aos litigantes, que abarcam desde consequências processuais desfavoráveis, até a aplicação de sanções pecuniárias, medidas coercitivas ou até mesmo sub-rogatórias pelo juiz, tudo a depender da situação peculiar de cada caso, como será tratado nos Capítulos 5 e 6 adiante. 
Em nosso entender, portanto, a antiga visão da prova como simples ônus da parte deve ser substituída por uma visão tridimensional do instituto, que se revela como ônus das partes, como poder do juiz e direito constitucional das partes, e, ainda, como projeção do dever geral de colaboração com o Poder Judiciário, sendo que todas essas concepções da prova encontram assento constitucional e infraconstitucional em nosso ordenamento jurídico. 


\section{DEVERES DE LEALDADE PROCESSUAL, VERACIDADE, BOA- FÉ E COLABORAÇÃO - O CONTEÚDO ÉTICO DO PROCESSO}

\subsection{Exigência de comportamento probo em juízo: o dever de lealdade processual}

A conduta das partes no processo civil é originalmente livre, limitada apenas à legalidade de seus atos, o que decorre das garantias constitucionais da liberdade e legalidade, também aplicáveis ao processo.

Essa liberdade, no entanto, sofre limitações de forma e de conteúdo. Quanto à forma, as limitações têm por objetivo ordenar a prática e a validade dos atos processuais. Já quanto ao conteúdo, as limitações se justificam diante do interesse público envolvido no processo e da concorrência de outras liberdades processuais que merecem ser preservadas $^{158}$. E, dentre as limitações de conteúdo está, justamente, a observância ao princípio da probidade processual $^{159}$.

O princípio da probidade é previsto, atualmente, em quase todos os ordenamentos jurídicos mundiais e se materializa no dever de lealdade processual, consistente na exigência de um comportamento leal, probo, honesto em juízo ${ }^{160}$.

A exigência de lealdade na atuação em juízo decorre, aliás, da própria natureza das regras de direito, fundadas que são nos valores e nas regras morais vigentes na sociedade em que se inserem.

Nesse sentido, Mendonça Lima, apoiado na conhecida ideia dos círculos concêntricos do direito e da moral lançada por Bentham, lembra que o direito está situado dentro da área (círculo) da moral, mas as regras da moral não se acham contidas na área (círculo) do direito, que é menor, sendo que a grande diferença entre ambas é que as regras de direito se revestem de coercitividade. Nesse sentido, não se pode conceber uma ordem jurídica, enquanto criação do homem, que não tenha fundamento na moral, o que também

\footnotetext{
${ }^{158}$ DINAMARCO, Cândido Rangel. Instituições de direito processual civil, cit., 6. ed., v. 1, p. 89.

${ }^{159}$ ABDO, Helena Najjar. O abuso do processo, cit., p. 127 e seg.

${ }^{160}$ Conforme defição de De Plácido e Silva, a palavra probo, do latim probus, corresponde ao sentido de justo, íntegro, honrado, cumpridor de seus deveres, cauteloso em suas obrigações, criterioso no modo de proceder. Cf. SILVA, De Plácido e. Vocabulário jurídico. Atualizadores: Nagib Slaibi Filho e Gláucia Carvalho. Rio de Janeiro: Forense, 2007.
} 
se aplica ao processo, enquanto instrumento estatal destinado à realização do direito material $^{161}$.

É certo, pois, que mesmo os doutrinadores que tradicionalmente tratavam o processo como um jogo ou luta ${ }^{162}$ - o que, em nosso entender, é resultado do individualismo e liberalismo então reinantes e não se coaduna com os pressupostos teóricos do direito processual contemporâneo ${ }^{163}$-, também reconhecem no princípio da probidade um limite à liberdade de atuação das partes no processo. Nas palavras de Liebman:

"embora no processo se trave uma luta em que cada um se vale livremente das armas disponíveis, essa liberdade encontra limite no dever de respeitar as 'regras do jogo' e estas exigem que os contendores se respeitem reciprocamente na sua qualidade de contraditores em juízo, segundo o princípio da igualdade das suas respectivas posições." ${ }^{\text {"164 }}$

No paradigma atual da ciência processual, especialmente dos ordenamentos que integram o sistema da civil law, como já se disse, não mais se entende aceitável a ideia do processo como verdadeiro duelo entre os litigantes no qual, no mais das vezes, indepentemente de quem seja o verdadeiro titular do direito, sagra-se vencedor o mais forte ou mais astuto, em detrimento do litigante mais fraco, mais inocente ou até mesmo representado por procurador menos habilidoso.

Essa antiga visão foi substituída pelo viés publicista do processo, ou seja, pelo reconhecimento dos objetivos públicos da atividade jurisdicional e também da natureza

\footnotetext{
${ }^{161}$ E completa: “O processo não é um meio isolado, mas, junto com o direito material, forma o complexo da ordem jurídica, em sua unidade e em seus fins. Como integrante deste conjunto, todo ele sob a égide da moral, o processo não pode permitir que os elementos que nele atuem, de qualquer modo, ajam fora dos limites da probidade, quer por atos omissivos ou comissivos." (MENDONÇA LIMA, Alcides. O princípio da probidade no Código de Processo Civil brasileiro. Revista de Processo, Rio de Janeiro, ano 4, p. 15-16, out./dez. 1979).

${ }^{162} \mathrm{~A}$ esse respeito verificar: CALAMANDREI. Piero. Il processo come giuoco. Rivista de Diritto Processuale, Padova, v. 5, pt. 1, p. 24-51, 1950 e CARNELUTTI, Francesco. Giuoco e processo. Rivista di Diritto Processuale, Milano, pt. 1, p. 102 e 105, 1951.

${ }^{163}$ Nesse sentido é o pensamento William dos Santos Ferreira: "O juiz, diferentemente do árbitro de futebol, como representante do Estado, do Poder Judiciário, tem, não somente o dever com o fair play processual, mas também com a qualidade do resultado. O processo não é um jogo, mas uma técnica empregada à serviço do melhor julgamento possível do caso concreto, voltado ao alcance de uma decisão justa." (Princípios fundamentais da prova cível, cit., p. 210). Também Brunela de Vieira Vincenzi assenta: "O processo já não deve ser encarado como jogo ou luta, pois merece ser visto e exercido com respeito às regras do contraditório efetivo e do processo justo e équo. A posição das partes e, principalmente, a liberdade a elas conferida pelo sistema processual civil de concepção individualista, por essas razões, está sendo repensada e limitada." VINCENZI, Brunela Vieria de. A boa-fé no processo civil. São Paulo: Atlas, 2003. p. 176.

${ }^{164}$ LIEBMAN, Enrico Tullio. Manual de direito processual civil, cit., v. 1, p. 124.
} 
social do processo ${ }^{165}$. Além disso, o processo civil contemporâneo, direcionado que é à efetividade, também não pode tolerar condutas que visem a elidir ou conspurcar a realização do direito material que se dá por seu intermédio ${ }^{166}$.

Por essas razões é que se, por um lado, aumentaram-se os poderes do juiz na direção e instrução do processo, por outro lado, passou-se a exigir das partes uma maior colaboração com o Judiciário na realização de sua atividade, o que pressupõe uma conduta processual adequada. Nas palavras de Mendonça Lima:

\begin{abstract}
"Quanto mais se reforçam os poderes do juiz, mais devem ser cerceadas as atitudes de improbidade, de quem quer que seja, evitando que a atuação do magistrado pudesse tornar-se inócua, se, como o representante do Estado, pudesse ser iludido, mal orientado ou burlado em sua missão de fazer justiça e de preservar a legalidade. A autoridade judiciária, portanto, encontraria óbices incompatíveis, como é óbvio, com a moderna posição a que foi erigida, em nome da própria ordem social, política e jurídica."167
\end{abstract}

Nesse sentido, por mais acirrados que estejam os ânimos num processo judicial, e, ainda, não obstante o natural anseio dos litigantes de se sagrarem vencedores, não se admite a utilização do ardil, o emprego da astúcia, ou a prática de ato desonesto para o alcance do êxito das pretensões deduzidas em juízo ${ }^{168}$.

O princípio da probidade, materializado no dever de lealdade processual, serve, pois, como freio ético e legal à atuação em juízo, mediante a fixação de limites socialmente aceitáveis de comportamento. Esses limites, por sua vez, não se impõem apenas aos

\footnotetext{
${ }^{165}$ Cf. ASSIS, Araken de. Dever de veracidade das partes no processo civil. Páginas do Direito, 31. Ago. 2012. Disponível em: <www.tex.pro.br/tex/listagem-de-artigos/362-artigos-ago-2012/8769-dever-deveracidade-das-partes-no-processo-civil>.

${ }^{166}$ Conforme acentua Carpena: "A deslealdade, o abuso de direito e a chicana processual, de fato, descredibilizam a prestação da Justiça, não só porque maltratam a parte adversa que sofre seus efeitos, mas também porque prejudicam o Estado e a própria sociedade, que acabam pagando o preço de ter uma prestação jurisdicional que perde tempo e dinheiro com atitudes desarrazoadas e absolutamente despropositadas, deixando-se de atender, nesse momento, pleitos legítimos." (CARPENA, Marcio Louzada. Da (des) lealdade no processo civil: visões críticas do processo civil brasileiro. Porto Alegre: Livr. do Advogado, 2005. p. 34).

${ }^{167}$ MENDONÇA LIMA, Alcides. O dever de verdade no Código de Processo Civil brasileiro. Revista Forense, Rio de Janeiro, ano 54, n. 172, p. 42-43, jul./ago. 1957.

168“"A alta finalidade pública do processo civil, que consiste na verificação de fatos ocorridos, como pressupostos da aplicação adequada da lei no caso concreto ('justa composição da lide, no dizer expressivo, mas menos preciso, de Carnelutti) não pode, no direito positivo brasileiro, prescindir da colaboração ética das partes. Caso contrário, o juiz teria de 'lutar' em realidade, 'contra' os próprios litigantes que, por sua vez, lutariam violentamente, entre si, ao arrepio da mais elementar ética." (ARRUDA ALVIM, José Manoel de. Deveres das partes e dos procuradores no direito processual civil brasileiro (a lealdade no processo). Revista de Processo, São Paulo, v. 18, n. 69, p. 10, jan./mar. 1993).
} 
litigantes, mas se estendem a todos aqueles que de qualquer forma participem do processo, incluindo-se os defensores das partes, o juiz, as testemunhas, o perito, etc ${ }^{169}$.

No que respeita ao ordenamento jurídico brasileiro, o CPC de 1973, atualmente em vigor, superando a anterior resistência à imposição de deveres éticos aos litigantes (decorrente, ainda, da influência da doutrina privatista) e assumindo os postulados do processo civil de viés publicista, positivou o dever de lealdade processual (art. 14, II), preocupação essa, aliás, já estampada na própria Exposição de Motivos, nesses termos:

\begin{abstract}
"Posto que o processo civil seja, de sua índole, eminentemente dialético, é reprovável que as partes se sirvam dele, faltando ao dever da verdade, agindo com deslealdade e empregando artifícios fraudulentos; porque tal conduta não se compadece com a dignidade de um instrumento que o Estado põe à disposição dos contendores para atuação do direito e realização da Justiça."
\end{abstract}

O artigo14, CPC, na redação original, impunha os deveres de lealdade e boa-fé "às partes e aos procuradores", e, após a alteração promovida pela Lei 10.358/2001, passou a estendê-los a "todos aqueles que de qualquer forma participam do processo". Com isso, parece ter o legislador positivado um dever de cooperação não apenas das partes diretamente envolvidas, mas de toda a sociedade no que tange à adequada tramitação de cada processo.

O legislador brasileiro - diversamente do italiano, que adotou uma formulação genérica do dever de lealdade (art. 88) ${ }^{170}$-, optou por uma técnica casuística, arrolando expressamente, no próprio artigo 14 já mencionado, um conjunto de deveres que compõem o princípio da probidade, quais sejam: o de expor os fatos em juízo conforme a verdade (art. 14, I), o de proceder com lealdade e boa-fé (art. 14, II), o de não formular pretensões nem alegar defesa cientes de que destituídas de fundamento (art. 14, III), o de não produzir provas nem praticar atos inúteis à declaração ou defesa do direito (art. 14, IV) e o de

\footnotetext{
${ }^{169}$ Como bem reconhece Theodoro Junior, há um empenho do direito processual contemporâneo de refrear os impulsos dos litigantes e de seus representantes no sentido de transformar o processo em meio de embate de interesses vis, com o emprego de todo tipo de malícia. (Cf. THEODORO JÚNIOR, Humberto. Abuso do direito processual no ordenamento jurídico brasileiro. In: BARBOSA MOREIRA, José Carlos (Coord.). Abuso dos direitos processuais. Rio de Janeiro: Forense, 2000).

${ }^{170} \mathrm{O}$ dispositivo prevê que "le parti e i loro difensori hanno il dovere di comportarsi min giudizio con lealtà e probità. In caso di mancanza dei difensori a tale dovere, il giudice deve riferirne alle autorità che esercitano il potere disciplinares u di esse."
} 
cumprir com exatidão os provimentos mandamentais emanados da autoridade judicial e não criar embaraços à efetivação das decisões judiciais $(\operatorname{art.} 14, \mathrm{~V})^{171}$.

Em complemento, o artigo 17 do CPC positivou condutas caracterizadoras da litigância de má-fé e violadoras dos deveres de conduta previstos no artigo 14.

O princípio da probidade processual, ademais, permeia diversos outros dispositivos do CPC em vigor ${ }^{172}$ e sua inobservância gera responsabilidade por dano processual (art 16 a 18), tal como ocorre com aquele que deixa de fazer nomeação à autoria ou o faz em nome de pessoa diversa da correta (art. 69, CPC), com a parte que deixa de arguir a incompetência absoluta do juiz na primeira oportunidade de falar nos autos (art. 113, CPC), ou então com a parte que requer a citação por edital alegando dolosamente os requisitos legais (art. 233, CPC), dentre outros tantos exemplos.

O juiz, por sua vez, na qualidade de diretor do processo, além de ter o dever de cobrar das partes uma postura processualmente adequada (art. 125, CPC), também está sujeito, ele próprio, à observância de normas ético-jurídicas, responsabilizando-se por eventuais danos causados às partes em razão da inobservância desses deveres (art. 133, CPC).

Aliás, com relação ao juiz, considerando-se que as situações jurídicas de que é titular no processo consubstanciam-se, em sua grande maioria, em poderes-deveres (vide item 2.2 supra), entende-se que o eventual abuso por ele cometido relaciona-se com a figura do abuso de poder e equivale, portanto, à prática de uma arbitrariedade ${ }^{173}$.

O dever de lealdade processual, por seu turno, abarca também o dever de veracidade, que se revela como uma de suas facetas mais sensíveis ${ }^{174}$, e que merece especial atenção em nosso estudo.

\footnotetext{
${ }^{171}$ Inciso acrescentado pela Lei 10.358/2001, que inseriu o contempt of court civil brasileiro. Para uma abordagem crítica dessa inovação legislativa e da desconfiguração do contempt of court brasileiro em relação à doutrina e à prática dos tribunais anglo-saxões cf. GRINOVER, Ada Pellegrini. Paixão e morte do "contempt of court" brasileiro (art. 14 do Código de Processo Civil). In: CALMON, Eliana (Org.). Direito processual: inovações e perspectivas: estudos em homenagem ao Ministro Sálvio de Figueiredo Teixeira. São Paulo: Saraiva: 2003. p. 1-11.

${ }^{172}$ Vale citar, a título exemplificativo, os artigos 15, 17, 18, 22, 31, 125, 133, 600 e 601.

${ }^{173}$ ABDO, Helena Najjar. O abuso do processo, cit., p. 183 e seg.

${ }^{174}$ Relembrem-se, a esse respeito, as considerações realizadas no item 2.1 deste estudo a respeito das questões filosóficas que envolvem o conceito de verdade e das dificuldades de caracterização e obtenção da verdade no processo judicial.
} 


\subsection{Caracterização e extensão do dever de veracidade}

O dever de veracidade remonta à origem da civilização, faz parte dos livros sagrados (Velho Testamento) e foi louvado por inúmeros religiosos, filósofos e pensadores, como Santo Agostinho, São Tomás de Aquino, entre outros ${ }^{175}$. A doutrinaaponta também suas fontes remotas no direito grego, romano e canônico.

Conforme ensina Mendonça Lima ${ }^{176}$, em épocas mais recentes, os Códigos sueco, finlandês, dinamarquês, húngaro, chinês e dos Estados Unidos da América, a despeito de sua formação de índole privatista, não deixaram de inserir disposições a respeito da exigência do dever de veracidade dos litigantes.

A partir da evolução científica do processo, datada do século XIX, quando passou a assumir seu caráter publicista, vários códigos passaram a prever expressamente o dever de veracidade, como é caso do código austríaco de 1895 (art. 178), alemão de 1933 (§ 128) e italiano de 1940 (art. 88).

Chiovenda sustenta, no entanto, que mesmo antes de haver formulação expressa no direito positivo, o dever de veracidade já decorria das regras gerais do direito, preexistindo um dever de boa-fé que correspondia, no processo, "à obrigação de não afirmar conscientemente coisas contrárias à verdade" ${ }^{177}$. Também Couture entende o dever de veracidade como norma impositiva e vigente no direito independentemente de texto expresso de lei ou de previsão de sanções específicas ${ }^{178}$.

Há quem entenda, no entanto, tratar-se de dever puramente moral, pois seria equivocado impor às partes o dever de veracidade em um procedimento destinado à satisfação de direitos pessoais ${ }^{179}$.

O dever de veracidade, de maneira geral, consiste no dever das partes de fazer corresponder suas alegações à realidade e de não alegar fatos ou fazer afirmações em juízo cientes de que são destituídas de fundamento. A sua finalidade é, em síntese, evitar que o

\footnotetext{
${ }^{175}$ ABDO, Helena Najjar. O abuso do processo, cit., p. 134.

${ }^{176}$ MENDONÇA LIMA, Alcides. O dever de verdade no Código de Processo Civil brasileiro, cit., p. 42-43.

${ }^{177}$ CHIOVENDA, Giuseppe. Instituições de direito processual civil, cit., v. 2, p. 496, no 271.

${ }^{178}$ COUTURE, Eduardo. El deber de decir la verdade en juicio civil. Montevideo: Barreiro Y Ramos, 1938. p. 31.

${ }^{179}$ Nesse sentido W. KISH, "Elementos de Derecho Procesal Civil", trad. espanhola, p. 121, no III, apud MENDONÇA LIMA, Alcides. O dever de verdade no Código de Processo Civil brasileiro, cit. e CUNHA, Oscar. Atti del Congresso Internazionale di Diritto Processuale Civile. Padova, 1953. p. 219.
} 
juiz profira decisão com base em convicção fundada em falsos subsídios trazidos pelas $\operatorname{partes}^{180}$.

No Brasil, a matéria passou a ser tratada expressamente pela legislação processual a partir do Código de Processo Civil de 1939, que, inspirado nos estudos preparatórios do Código Italiano, previa no artigo 63, e $\S 1^{\circ}$ que, independentemente do resultado da lide, a parte que tivesse alterado intencionalmente a verdade, ou litigado de forma temerária, seria condenada a reembolsar a parte contrária das custas processuais e honorários advocatícios.

O CPC de 1973, dando nova conotação à matéria, passou a tratar de forma mais abrangente do princípio da probidade processual (não se restringindo ao dever de veracidade) e alargou a esfera de aplicação do instituto, estendendo-o de forma expressa a todos que intervém no processo, juiz, ministério público, peritos, auxiliares da justiça, testemunhas, etc., como já se viu acima.

No que respeita, especificamente, ao dever de veracidade, o CPC de 1973 trata da questão em três principais dispositivos (art. 14, I, III e art. 17, II). No primeiro, estabelece como dever das partes e de todos aqueles que participam do processo o de "expor os fatos em juízo conforme a verdade”, no segundo impõe um dever de abstenção, consistente em "não formular pretensões, nem alegar defesa, cientes de que são destituídas de fundamento", sendo, pelo terceiro, reputado litigante de má-fé aquele que "alterar a verdade dos fatos".

A primeira questão que surge a esse respeito é se o dever de veracidade deve ser tomado pelo prisma objetivo ou subjetivo, ou seja, se para a configuração da violação a esse dever é necessária a consciência da parte sobre a inveracidade da afirmação.

Em nosso entender, ao menos no ordenamento jurídico brasileiro a resposta é positiva, eis que se trata de um dever de verdade subjetiva, tanto assim que o artigo 14, III, acima citado, utiliza a expressão "cientes que são destituídas de fundamento". Ou seja, a parte deve apresentar os fatos em juízo conforme acreditados subjetivamente e de acordo com os elementos de convicção de que dispõe naquele momento.

\footnotetext{
${ }^{180}$ Nesse sentido, Alcides de Mendonça Lima esclarece: "É evidente que, pela própria finalidade do processo, pelo interesse que a coletividade tem numa solução que expresse, tanto quanto possível, a justiça e o respeito às normas legais, as partes não podem servir-se de falsidades, mentiras, engodos, de modo a criarem, por meio da farsa, uma situação irreal, que não corresponda à verdade, de maneira alguma, nem mesmo relativa, iludindo o juiz, que será forçado a decidir de modo diferente ao que, normalmente, faria, se outros fossem os fatos de seu conhecimento." (MENDONÇA LIMA, Alcides. O dever de verdade no Código de Processo Civil brasileiro, cit., p. 44).
} 
Arruda Alvim, apoiado nos ensinamentos de Lent, também defende que a obrigação de dizer a verdade é, antes de tudo, de ordem subjetiva e não objetiva, sendo a regra que o litigante deve, subjetivamente, crer no que afirma e sua versão haverá de, possivelmente, vir a ser comprovada em juízo ${ }^{181}$.

Cresci Sobrinho, na mesma linha de entendimento, analisando o Anteprojeto do CPC de 1973, após estudo de direito comparado com o direito alemão, italiano e português, afirma que o dever de veracidade disciplinado no ordenamento brasileiro é dever à verdade subjetiva, sendo que "a parte está obrigada a declarar aquilo que, segundo seu melhor saber e consciência, tem como verdadeiro" ${ }^{\prime 182}$.

Bem exemplificando a questão, Cresci Sobrinho, em momento anterior de seu estudo, já havia afirmado que o paciente que aciona judicialmente seu dentista, pretendendo uma reparação civil por erro profissional, em raríssimos casos é capaz de conhecer positivamente, de antemão, tanto a culpa quanto o erro alegados, sendo que na maioria dos casos a comprovação das alegações dependerá de prova técnica, cujo resultado poderá, no entanto, contrariar a tese do demandante. Esse fato, contudo, não importa violação ao dever de veracidade que "em primeira linha, dirige-se à negativa: nada afirmar cuja inveracidade a parte reconheça positivamente". ${ }^{183}$

O exemplo acima citado, aliás, nos remete às considerações já tecidas no item 2.3.3 supra a respeito da relação entre o dever de veracidade no processo e o momento de constituição da prova.

Afinal, conforme bem ensina Yarshell, em um sistema processual como o brasileiro, em que a prova dos fatos não é, em regra, realizada antecipadamente, mas sim no curso do procedimento, a análise da veracidade da afirmação das partes somente pode ser realizada sob o prisma subjetivo, sob pena de se reputar violador do dever de veracidade (e, pois, litigante de má-fé) todo aquele que sucumbir em sua pretensão, o que se mostraria verdadeiro absurdo.

Neste ponto, aliás, como já se disse, diferenciam-se consideravelmente os sistemas jurídicos da common law e da civil law, já que nos primeiros, tendo as partes à sua

\footnotetext{
${ }^{181}$ ARRUDA ALVIM, Jose Manoel. Deveres das partes e dos procuradores no direito processual civil brasileiro (a lealdade no processo), cit., p. 13.

${ }^{182}$ CRESCI SOBRINHO, Elicio de. Contribuição ao estudo do dever de veracidade das partes, no processo civil, cit., p. 186.

${ }^{183}$ CRESCI SOBRINHO, Elicio de. Contribuição ao estudo do dever de veracidade das partes, no processo civil, cit. p. 178 e seg.
} 
disposição mecanismos de instrução preliminar, é certo que, desde a propositura da ação já dispõem, de forma praticamente completa, dos elementos para aferir a correção de suas afirmações e as chances de êxito de sua pretensão, o que faz robustecer o dever de veracidade e a possibilidade de analisá-lo objetivamente. Já nos sistemas da civil law, em que a fase probatória se desenvolve, em regra, a posteriori - no curso do processo de conhecimento -, "carece de maior respaldo jurídico e ético exigir das partes um dever de veracidade sob o prisma objetivo". ${ }^{184}$

É justamente por esse motivo que, em nosso entender, para se analisar a violação do dever de veracidade por qualquer das partes deve-se considerar, primordialmente, o momento em que realizada determinada afirmação dos fatos e os elementos probatórios já produzidos ou ao menos a elas disponíveis até aquele momento.

Exemplificando: deve ser reputada litigante de má-fé, violadora do dever de veracidade, a parte que, para justificar a inexigibilidade de determinado título e a obtenção de liminar para a sustação do respectivo protesto, afirma jamais ter contratado com a parte contrária, quando esta, em momento posterior, faz prova da efetiva existência do contrato, assinado de próprio punho pela parte autora. Ora, nesse caso, o contrato já existia no momento da afirmação inverídica da parte autora, que usou de má-fé e de malícia para ludibriar o juiz e alcançar decisão favorável à sua pretensão.

De outro turno, não viola o dever de veracidade o parente de paciente morto em procedimento cirúrgico que postula indenização alegando erro médico, se, na fase instrutória do processo, é atestado pela prova pericial que o óbito decorreu de reação absolutamente excepcional e imprevisível do organismo do paciente, apesar de terem sido adotadas todos os procedimentos recomendados pela literatura médica. Nesse caso, diferentemente do exemplo anterior, no momento da propositura da ação o autor, por não deter conhecimento técnico, não tinha como saber que realmente não houve falha humana. Consequentemente, desde que não tenha havido alteração proposital dos fatos, não há violação ao dever de veracidade.

Outro aspecto relevante diz respeito ao alcance do dever de veracidade, ou seja, quais as alegações das partes estão sujeitas ao dever de veracidade e se também a omissão pode caracterizar infração a esse dever. Nesse aspecto a doutrina nacional e estrangeira são bastante diversificadas.

\footnotetext{
${ }^{184}$ YARSHELL, Flávio Luiz. Antecipação da prova sem o requisito da urgência e direito autônomo à prova, cit., p. 180.
} 
Na doutrina estrangeira, Grossmann ${ }^{185}$ e Luso Soares ${ }^{186}$ podem ser citados entre os que defendem um dever amplo e quase pleno do litigante de dizer a verdade, abrangendo as manifestações positivas e negativas, as condutas comissivas (afirmações) e omissivas (o silêncio ou manifestação incompleta sobre determinado fato), os fatos principais e acidentais, os fatos controvertidos e até mesmo os não discutidos em juízo.

Em sentido contrário, Satta $^{187}$, absolutamente cético quanto ao princípio consagrado no art. 88 do CPC italiano, aceita a possibilidade tanto da omissão, como da própria inveracidade no processo, já que a parte não pode ser obrigada a comportar-se contra seu interesse, sendo que a liberdade da parte no processo apenas é limitada pela vedação à prática de ato ilícito.

Na doutrina brasileira, Arruda Alvim, analisando a questão ainda ao tempo da redação original do artigo 17, I, do CPC de 1973, entendia que o dever de veracidade abarca tanto o dever de dizer a verdade propriamente dito (ou de não afirmar o que sabe ser falso), como também o chamado dever de completude, que consiste no dever de "dar uma versão completa dos fatos" ou de "não dever haver omissão sobre um fato essencial à demanda" ${ }^{\prime 188}$.

Àquele tempo, veja-se, o dever de completude estava positivado no artigo 17, I, do $\mathrm{CPC}$, que reputava litigante de má-fé aquele que omitisse "intencionalmente fatos essenciais ao julgamento da causa". Essa disposição, no entanto, foi posteriormente modificada pela Lei $6.771 / 80$, por redação vigente até os dias atuais, que determina ser litigante de má-fé quem "deduzir pretensão ou defesa contra texto expresso de lei ou fato incontroverso".

Observa-se, no entanto, que mesmo à época da redação original do CPC, Arruda Alvim já pontuava que a "versão completa dos fatos" queria significar que a parte não pode sonegar informações de tal forma que a versão dos fatos se torne inverídica ${ }^{189}$.

\footnotetext{
${ }^{185}$ GROSSMAN, Kaethe. O dever de veracidade das partes no processo civil (aspecto doutrinário). Revista Forense, Rio de Janeiro, v. 101, p. 279-290, jan. 1945.

${ }^{186}$ SOARES, Fernando Luso. A responsabilidade processual civil. Coimbra: Almedina, 1987.

${ }^{187}$ SATTA, Salvatore. Commentario al Codice di Procedura Civile. Ristampa da ed. de 1959. Milano: F. Vallardi, 1966. v. 1, p. 290-292.

${ }^{188}$ ALVIM NETO, Jose Manoel de Arruda. Deveres das partes e dos procuradores no direito processual civil brasileiro (a lealdade no processo), cit., p. 11-12.

189“Por outras palavras, é necessário interpretar-se a necessidade de versão completa dos fatos, à luz do princípio dispositivo, indicativo de que à parte é lícito escolher os fatos que embasem sua ação, salvo o comprometimento da verdade." (ARRUDA ALVIM, Jose Manoel de. Deveres das partes e dos procuradores no direito processual civil brasileiro (a lealdade no processo), cit., nota 53, p. 19).
} 
Theodoro Júnior ${ }^{190}$, citando Cresci Sobrinho e Celso Barbi, também sustenta que o que se nega às partes são as “afirmações e contestações positivamente falsas", ou seja, aquelas que "os litigantes sabem conscientemente que são falsas" e "intencionalmente as produzem”. Assim, em seu entender, não tem o litigante a obrigação de deduzir todos os elementos desfavoráveis a ele e favoráveis ao adversário. O que a lei censura são atitudes que ultrapassem os limites "que o costume e a moral social estabelecem", aquilo que para os advogados se coloca como "exigências de correção profissional". ${ }^{191}$.

Mendonça Lima adverte, nesse mesmo sentido, que a matéria é de difícil conceituação e formulação legal, eis que a ideia levada ao extremo poderia implicar exigir da parte comportamento lesivo a si própria e favorável ao adversário, o que contrariaria a própria natureza humana. Daí a necessidade de agudeza de espírito do julgador na avaliação da conduta processual das partes:

"Percebe-se, sem dúvida, que o problema é difícil e complexo porque
joga com o elemento humano, dentro da consciência de cada um,
ambiente praticamente infenso às prescrições legais. Cabe ao juiz aferir a
essência do comportamento das partes, dos procuradores e de terceiros.
Se houver rigor extremo, qualquer ato ou atitude menos clara poderão
determinar punições injustas, se não tiver havido a intenção de mentir ou
de faltar com a verdade; se houver tolerência, será um estímulo à
improbidade. Em qualquer dos casos a solução será iníqua e produzirá
malefícios, quem sabe se irremediáveis."

Araken de Assis, de forma aparentemente contrária, defende o que chama de um "regime rigoroso" no exame do dever de veracidade, que deve abarcar tanto o dever de a parte alegar somente fatos verdadeiros, abstendo-se de alegar os que saiba serem inverídicos, como o dever de a parte alegar todos os fatos, abastendo-se de omitir os fatos relevantes que conheça e, eventualmente, favoreça no todo ou em parte o adversário.

Em exemplo citado pelo doutrinador, no entanto, a posição por ele adotada parece se filiar ao entendimento dos doutrinadores brasileiros anteriormente citados, já que, harmonizando o dever de veracidade com o princípio dispositivo, o autor aceita a possibilidade de a parte escolher uma dentre diversas causas de pedir porventura existentes

\footnotetext{
${ }^{190}$ THEODORO JÚNIOR, Humberto. Abuso do direito processual no ordenamento jurídico brasileiro, cit., p. 100-101.

${ }^{191}$ Em sentido muito mais restritivo é o pensamento de Gioconda Fianco Pitt. Cf. Dever de veracidade no processo civil brasileiro e sua relação com o instituto da Discovery no processo norte-americano da common law, cit.

${ }^{192}$ MENDONÇA LIMA, Alcides. O dever de verdade no Código de Processo Civil brasileiro, cit., p. 46.
} 
e, assim, selecionar os fatos trazidos a juízo, desde que não comprometa a veracidade das alegações $^{193}$.

De fato, não se pode perder de vista que é da natureza humana, até mesmo por uma reação psicológica natural, valer-se de todos os meios disponíveis para a defesa de seus interesses em juízo, conduta essa que deve ser fiscalizada de modo a impedir a violação de direitos alheios ou dos princípios atinentes à função jurisdicional do Estado. Afinal, a alegação de fatos inverídicos pelas partes, além de trazer prejuízo à defesa da parte contrária, implica, no mais das vezes, desperdício de atividade processual, com perda de tempo e dinheiro na realização de atos e produção de provas absolutamente desnecessárias ao processo.

No entanto, o dever de veracidade não pode ser levado ao extremo de exigir das partes que ofereçam, voluntariamente, subsídios à defesa do adversário, como, por exemplo, expondo o autor fatos não essenciais ao julgamento da causa e que fundamentariam, por exemplo, uma eventual ação reconvencional pelo réu.

Ou seja, a omissão admitida deve ter como limite a veracidade da exposição fática, ou seja, o fato omitido não pode ser de tal ordem que torne inverídica a narrativa como um todo. Nesse sentido, não pode a parte autora executar um contrato de mútuo e omitir o recebimento de uma das parcelas, ou então omitir fato essencial ao julgamento da causa, tal como a existência de uma ação anterior com objeto idêntico ao do processo em curso, já transitada em julgado ${ }^{194}$.

Os deveres de lealdade e de veracidade, ademais, não sofrem nenhum tipo de variação em razão da natureza dos direitos discutidos, sendo indiferente se a ação judicial versa sobre direitos disponíveis ou indisponíveis. Isto porque, como já se viu, esse dever se harmoniza com o caráter público e social do processo civil, características que não se modificam em razão da natureza dos interesses em disputa ${ }^{195}$.

\footnotetext{
${ }^{193}$ O exemplo citado diz respeito a uma ação de separação judicial em que o marido, ao invés de alegar o motivo real da impossibilidade de convivência, que é o adultério, alega outra causa de pedir igualmente hábil, qual seja, a embriaguez. Cf. ASSIS, Araken de. Dever de veracidade das partes no processo civil, cit. ${ }^{194}$ Os exemplos são de Helena Najjar Abdo. Cf. O abuso do processo, cit., p. 140.

195، “...) independentemente da natureza disponível do direito debatido pelos interessados, o uso do processo para solução de conflitos de interesses não admite o emprego, pelas partes, de meios moralmente reprováveis para realização do desejo de ver vitoriosa sua versão parcial. Em outras palavras, a partir do momento em que as partes submetem suas pretensões ao exame e decisão de um órgão público de solução de controvérsias, passa a ser obrigatória a utilização de conduta condizente com um padrão ético mínimo, que não admite a mentira, a malícia exagerada, a falta de respeito para com o juiz e/ou para com a outra parte, além de não se coadunar com o exercício abusivo dos atos processuais (...)" (PUOLI, José Carlos Baptista. Os poderes do juiz e as reformas do processo civil. São Paulo: Juarez de Oliveira, 2002. p. 180).
} 
O dever de veracidade, pois, não é anulado, tampouco minimizado, pela incidência do princípio dispositivo, pois, conforme será mais detidamente abordado no Capítulo 4, item 4.1.1 infra, na atual fase da ciência processual, a influência do princípio dispositivo é circunscrita aos reflexos que a relação de direito material possa produzir no processo, ou seja, à possibilidade de disposição sobre o objeto litigioso, além da natural iniciativa do autor de inaugurar o processo e de alegar os fatos que formarão o objeto litigioso.

Pelo que se pode extrair, portanto, o dever de lealdade processual e seu natural desdobramento - o dever de veracidade na exposição dos fatos em juízo - também constitui uma faceta do denominado dever de colaboração das partes com o Poder Judiciário no esclarecimento dos fatos e no desenvolvimento da atividade jurisdicional. Nesse sentido, é a atenta observação de Cruz e Tucci, ao se referir às disposições do artigo 14, do CPC:

\footnotetext{
"A lei processual impõe aí uma postura essencialmente ética aos litigantes e aos seus representantes judiciais, de sorte a instá-los, sob a ameaça das sanções especificadas nos subsequentes arts. 16, 17 e 18, a cooperar com a celeridade do procedimento e com a atuação do órgão jurisdicional na aplicação do direito."196
}

Esse dever, no entanto, sofre limitações decorrentes de eventual conflito com bens de maior importância para o ordenamento jurídico, tal como o direito à vida, à saúde e à liberdade, muitas dessas hipóteses, aliás, expressamente previstas no ordenamento jurídico brasileiro, matéria que será retomada no Capítulo 5, item 5.2.3 infra.

A infração aos deveres de lealdade e de veracidade, por sua vez, é tratada por parcela respeitável da doutrina sob o aspecto do abuso do processo, já que se verifica nessas condutas um desvio das finalidades públicas que regem a atividade jurisidional.

Nesse sentido, reputamos importante analisar, neste ponto de nosso estudo, a teoria do abuso do processo e a responsabilidade que decorre da improbidade processual.

\footnotetext{
${ }^{196}$ CRUZ E TUCCI, José Rogério. Repressão ao dolo processual: o novo art. 14 do CPC. Revista Jurídica, Porto Alegre, v. 50, n. 292, p. 15, fev. 2002.
} 


\subsection{Abuso do processo e responsabilidade por improbidade processual}

\subsubsection{Abuso do direito e abuso do processo}

A teoria do abuso do processo tem suas bases na teoria do abuso do direito, oriunda do direito privado ${ }^{197}$.

A teoria do abuso do direito, tal como concebida na atualidade, teve origem na segunda metade do século XX, por força de criação jurisprudencial francesa, como reação à mentalidade individualista das legislações do século XIX, que não admitiam qualquer limitação aos direitos subjetivos.

Apesar das diversas censuras que sofreu ao longo dos anos ${ }^{198}$, a teoria do abuso do direito está presente, na atualidade, em praticamente em todos os ordenamentos jurídicos. Corresponde, em linhas gerais, ao exercício irregular de um direito subjetivo, que excede seus limites e causa prejuízo a terceiros.

Essa teoria tem sua base nos ideários do Estado Social e Democrático de Direito e na consequente limitação do exercício dos direitos subjetivos ao atendimento de seus fins sociais, ou seja, da finalidade a que se destina a norma jurídica ${ }^{199}$.

Em estudo aprofundado das diversas teorias sobre o abuso de direito, Abdo ensina que, não obstante as divergências pontuais, todas elas comungam de três noções básicas caracterizadoras do ato abusivo: a aparência de legalidade do ato, a preexistência de um direito subjetivo, e o fato de o abuso referir-se ao exercício do direito e não ao direito em si. Diferenciam-se, a partir daí, as teorias chamadas subjetivistas, objetivistas e mistas, pela

\footnotetext{
${ }^{197}$ THEODORO JÚNIOR, Humberto. Abuso do direito processual no ordenamento jurídico brasileiro, cit.

${ }^{198}$ Dentre as críticas mais ferrenhas destaca-se a de Planiol que, sustentando o caráter absoluto dos direitos subjetivos, não admitia qualquer limitação ao seu exercício, identificando o abuso do direito com a ilegalidade, pois o excesso do agente nada mais seria que uma atuação sem direito. Para os irmãos Mazeud, o abuso do direito seria um ato ilícito por excelência, resultante da aplicação dos princípios da responsabilidade civil, não havendo razão para se falar em fins sociais dos direitos. Há, ainda, quem defenda tratar-se o abuso de direito de um conceito sociológico, metajurídico, sujeitando-se à repressão apenas social e moral, mas não do direito, já que para este o ato seria perfeitamente lícito. (cf. ABDO, Helena Najjar. O abuso do processo, cit., p. 43-44).

${ }^{199}$ Segundo Pietro Rescigno "quando si parla di abuso, di possibilità di abuso del diritto, si viene a dire che l'esercizio di questa libertà garantita della norma, del potere accordato dalla legge, può dare luogo a responsabilità: onde in atto lecito - l'esercizio del diritto - diviene fonte di responsabilità. Significa sottintendere ala libertà ed al potere un limite, ed il limite, la misura sembrano vaghi e sfuggenti." (RESCIGNO, Pietro. L’abuso del diritto. Bolonha: Il Mulino, 1998).
} 
maior ou menor (ou até nenhuma) participação do elemento anímico, ou seja, pela necessidade ou não da investigação sobre a intenção do agente ${ }^{200}$.

O abuso do processo, como já se disse, tem seu fundamento na teoria do abuso do direito. Porém, tratando-se de abuso cometido no âmbito do processo, seus sujeitos, naturalmente, são os que compõem a relação jurídica processual.

Ademais, se no âmbito do direito privado a teoria do abuso do direito se assenta no exercício irregular dos direitos subjetivos, no processo o abuso se relaciona ao exercício anormal ou incorreto das múltiplas posições ou situações jurídicas que os sujeitos assumem na relação processual, e que já foram tratadas no item 2.2 supra.

Segundo Taruffo ${ }^{201}$, assim como a caracterização do abuso do direito pressupõe a existência do direito subjetivo, no âmbito do processo apenas pode se verificar o abuso quando o sujeito é titular de uma posição processual. Do contrário, caracterizado estará o ato ilícito e não o abuso do direito. Assim ocorre, no exemplo de Taruffo, quando é proferida uma sentença por quem não é juiz. Não se trata aqui de abuso do processo por terceiro, mas de ato inexistente para o mundo jurídico.

De fato, conforme entendimento doutrinário predominante, o ato ilícito se distingue do ato abusivo, muito embora ambos sejam fonte de responsabilidade civil.

O primeiro caracteriza-se pela violação frontal à lei e pressupõe a inexistência de qualquer direito do agente, ao passo que o segundo depende, para sua caracterização, da existência prévia de um direito (ou de uma posição subjetiva, no caso do abuso do processo), que é exercido com aparência de legalidade, porém com desvio de finalidade ${ }^{202}$.

A despeito dos limites de forma e de conteúdo previstos no ordenamento jurídico para a prática dos atos processuais, existe uma margem de manobra, uma certa liberdade com a qual as partes podem exercer suas respectivas situações jurídicas subjetivas (poderes, faculdades, ônus e deveres). Conforme ensina Taruffo ${ }^{203}$, é justamente quando o

\footnotetext{
${ }^{200}$ Para a verificação de cada uma das teorias e seus principais exponentes consultar ABDO, Helena Najjar. $O$ abuso do processo, cit., p. 37-46.

${ }^{201}$ TARUFFO, Michele. Elementi per una definizione di “abuso del processo". In: L'ABUSO del diritto. Padova: Cedam, 1997. p. 439. (Diritto privado, v. 3).

${ }^{202}$ Nesse sentido Humberto Theodoro Junior explicita: "o ato que ofende frontalmente a lei não tem sequer a aparência de legalidade. É incapaz de produzir efeitos porque atrita frontalmente com a vontade legal. $O$ agente, de forma alguma, teria legitimidade para praticá-lo. Já o ato abusivo se prende a uma faculdade legal que, em princípio, o agente detinha. O vício reside na forma com que o titular da faculdade a utilizou, desviando-a de sua normal objetividade”. (THEODORO JÚNIOR, Humberto. Abuso do direito processual no ordenamento jurídico brasileiro, cit., p. 111).

${ }^{203}$ TARUFFO, Michele. Elementi per una definizione di “abuso del processo", cit., p. 442.
} 
ordenamento possibilita maior e mais ampla liberdade na prática de determinado ato (ou seja, quando o sujeito processual não é rigorosamente vinculado ao esquema legal), que surgem as possibilidades de exercício irregular ou abusivo das situações jurídicas.

Calamandrei $^{204}$ identifica o abuso do processo nas variadas situações de má-fé processual em que a parte se serve do processo para obter efeitos que não lhe são próprios, conduta que entende situar-se em uma zona intermediária entre o dolo e a fraude e, porque semelhante à figura do abuso do direito, pode ser denominada de abuso do processo. De Stefano $^{205}$, nesse mesmo sentido, entende que na ideia de abuso do processo está a divergência entre os meios utilizados e os fins perseguidos.

Abdo, sintetizando essas posições doutrinárias, esclarece que, no abuso do processo, a discrepância, ou desvio de finalidade, se verifica entre os fins previstos pelo sistema para determinados meios e os aqueles efetivamente pretendidos pelo agente com a prática do ato ${ }^{206}$.

Destaca, no entanto, a importância de outros critérios identificados pela doutrina, e que, apesar de não essenciais como o desvio de finalidade, são úteis à identificação e caracterização do abuso do processo. São eles: a falta de seriedade do ato (aqui se enquadra a frivolouness - a leviandade ou frivolidade - referida nos sistemas da common law); ${ }^{207}$ a ilicitude ou ilegitimidade do escopo visado pelo agente (ou seja, a incompatibilidade entre $\mathrm{o}$ ato e os interesses que a lei pretende tutelar), ${ }^{208} \mathrm{e}$ a lesividade à administração da justiça (o contraste do ato com a exigência de eficiência da administração da justiça). ${ }^{209 .}$

Quanto à exigência do elemento subjetivo do agente, ou seja, a exigência de dolo ou culpa do agente para a caracterização do abuso do processo, Abdo, após explicitar as teorias subjetivista, objetivista e mista, ensina que o tratamento jurídico da matéria difere em razão da opção adotada pelo legislador em cada ordenamento jurídico, sendo certo que tratamento do tema pelo ordenamento jurídico brasileiro será abordado no item a seguir.

${ }^{204}$ CALAMANDREI. Piero. Il processo come giuoco, cit., p. 24-51.

${ }^{205}$ DE STEFANO, Giuseppe. Note sull'abuso del processo. Rivista Diritto Processuale, Padova, v. 19, pt. 1, p. 582-600, 1964.

${ }^{206}$ ABDO, Helena Najjar. $O$ abuso do processo, cit., p. 91.

${ }^{207}$ DE STEFANO, Giuseppe. Note sull'abuso del processo, cit., p. 582-600.

${ }^{208}$ TARUFFO, Michele. Elementi per una definizione di "abuso del processo", cit., p. 442.

${ }^{209}$ CORDOPATRI, Francesco. L'abuso del processo. Padova: Cedam, 2000. v. 1 e v. 2; THEODORO

JÚNIOR, Humberto. Abuso do direito processual no ordenamento jurídico brasileiro, cit.. 
Por fim, sustenta que o dano está invariavelmente presente na configuração do abuso do processo, pois, nas palavras de Taruffo $^{210}$, sem que se verifique, na prática, a ocorrência de consequências negativas, oriundas do ato praticado pelo sujeito processual, não há sequer utilidade para a teoria do abuso processo.

O dano, por sua vez, pode se materializar tanto em prejuízo patrimonial direto, como em potencialização do dano marginal (tempo natural do processo, já tratado no item 1.4 acima) ou até mesmo dano moral ao outro litigante. E, ainda que não se verifique a ocorrência de qualquer dessas hipóteses, o abuso do processo sempre acarretará, quando menos, dano à eficiência da administração da justiça, conforme reconhecido de maneira pacífica por respeitadíssima doutrina nacional e estrangeira ${ }^{211}$.

E o abuso pode se referir tanto à tutela jurisdicional em seu conjunto (abuso do "direito" de ação e de defesa) como a instrumentos processuais individualmente considerados $^{212}$.

No primeiro caso enquadram-se, segundo Abdo, a simulação processual (art. 129, CPC), a utilização do processo para conseguir objetivo ilegal (art. 17, III, CPC), a dedução de pretensão ou defesa contra texto expresso de lei ou fato incontroverso (art. 17, I, CPC) e o abuso da defesa ou manifesto propósito protelatório do réu (art. 273, II, CPC).

Podemos citar exemplos de abusos dessa natureza que, infelizmente, se verificam com frequência no cotidiano forense: a propositura de ações de conhecimento ou executivas sem fundamento plausível, visando apenas e tão-somente frustrar participação do réu em licitação ou frustrar negócio imobiliário (pela impossibilidade de obtenção de certidão negativa dos distribuidores forenses, por exemplo), ou, ainda, com o objetivo de desonrar o réu, com a inscrição de seu nome no cadastro de inadimplentes; o requererimento de falência com objetivo de pura e simplesmente constranger o devedor ao imediato pagamento de débito; e, ainda, o ajuizamento simultâneo de ações idênticas com

\footnotetext{
${ }^{210}$ TARUFFO, Michele. General report. In: TARUFFO, Michele (Ed.). Abuse of procedural rights: comparative standards of procedural fairness. Haia; Londres; Boston: Kluwer Law International, 1999.

${ }^{211}$ Nesse sentido: CORDOPATRI, Francesco. L'abuso del processo, cit., v. 2, p. 131-132; TARUFFO, Michele. Elementi per una definizione di "abuso del processo", cit., p. 436; THEODORO JÚNIOR, Humberto. Abuso do direito processual no ordenamento jurídico brasileiro, cit., p. 108-111; BARBOSA MOREIRA, José Carlos. A responsabilidade das partes por dano processual. Revista de Processo, São Paulo, n. 10, p. 16, 1978.

${ }^{212}$ Helena Najjar Abdo denomina a primeira forma de abuso (à tutela jurisdicional como um todo) de abuso macroscópico e a segunda (abuso dos instrumentos processuais individualmente considerados) de abuso microscópico. ABDO, Helena Najjar. O abuso do processo, cit., p.189-226.
} 
o objetivo de burlar o princípio do juiz natural, desistindo-se na sequência de todas aquelas que não forem distribuídas ao "juiz escolhido".

Exemplo prático, que alcançou considerável repercussão na imprensa ${ }^{213}$, consistiu no ajuizamento cadenciado e orquestrado, a partir do ano de 2009, de uma série de ações indenizatórias (mais de cem ações judiciais) por fiéis da Igreja Universal do Reino de Deus - e também pela própria Igreja Universal - em face da empresa jornalística responsável pela edição do jornal Folha de S. Paulo e de seus jornalistas, em razão da publicação de matérias supostamente ofensivas à referida Igreja. As ações, ajuizadas nos mais diversos rincões do país, impuseram à ré um pesadíssimo ônus financeiro, decorrente da necessidade de contratação de advogados, deslocamentos de representantes da empresa para a realização de audiências, ampliação abrupta de seu quadro jurídico para a administração desse contingente inesperado de processos, dentre outros, o que levou alguns juízes a, acertadamente, além de extinguir de pronto os processos, condenar os autores nas penas de litigância de má-fé.

No tocante aos abusos dos instrumentos processuais específicos, podem ser citados como exemplos a utilização de recurso meramente protelatório (art. 17, VII), como meio de resistência ao cumprimento da decisão judicial, muitas vezes com uso de petições padronizadas que sequer apresentam os motivos de reforma da decisão recorrida; a provocação de incidentes infundados (art. 17, VI), tais como o incidente de falsidade documental, a impugnação ao valor da causa ou a ação declaratória incidental sem fundamento, com o único objetivo de protelar o desfecho da ação; o uso indiscriminado das tutelas de urgência, omitindo ao juiz informações ou documentos essenciais que fazem cair por terra a verossimilhança da alegação ou simulando um periculum in mora inexistente; oposição de exceção de incompetência com o único objetivo de retardar o processo; a resistência do executado aos atos executivos ou em indicar bens passíveis de penhora, após intimado a tanto (art. 600, II, III e IV, CPC), dentre outros ${ }^{214}$.

Outros exemplos de abuso microscópico do processo que retiramos do cotidiano forense consistem nas falsas declarações de pobreza, com o intuito de obter indevidamente o benefício da gratuidade judiciária e furtar-se às consequências pecuniárias do

\footnotetext{
${ }^{213}$ À guisa de ilustração, consulte-se matéria publicada na versão eletrônica do jornal Folha de S. Paulo, em 15.11.12, TJ-SP rejeita última ação da Universal contra a Folha. Folha de S. Paulo, 15 nov. 2012. Disponível em: <http://www1.folha.uol.com.br/poder/1185926-tj-sp-rejeita-ultima-acao-da-universalcontra-a-folha.shtml>.

${ }^{214}$ Esses exemplos são todos de Helena Najjar Abdo. Cf. O abuso do processo, cit., p. 199-226.
} 
sucumbimento do pedido; na omissão proposital de dados pessoais do litigante na petição inicial ou na defesa, de modo a impossibilitar ou dificultar a sua localização e de seus bens na fase de cumprimento de sentença (ex: omissão do número do CPF ou indicação, como seu, do endereço profissional do advogado); e na renúncia proposital do advogado (ou revogação de seu mandato) na fase de cumprimento de sentença, de forma a impossibilitar a intimação do devedor em nome de seu patrono.

A instrução processual, por sua vez, também é campo propício a diversas espécies de abuso, como é o caso do requerimento de prova sabidamente inútil ou irrelevante, o requerimento de expedição de carta precatória ou rogatória para inquirição de testemunha com o intuito de postergar o desfecho da ação, a resistência à disponibilização de documentos necessários à realização da prova técnica, dentre outros.

Feitas essas considerações, cumpre-nos agora verificar o tratamento do abuso do processo especificamente no ordenamento jurídico brasileiro e sua relação com o conteúdo ético do processo, objeto de nossa atenção neste capítulo.

\subsubsection{Abuso do processo no ordenamento jurídico brasileiro e a responsabilidade por improbidade processual}

O direito processual brasileiro nas suas origens, herdado das tradições portuguesas, não continha um tratamento sistematizado do abuso do direito, a par da existência de algumas disposições legais que, de forma esparsa e fragmentada, impunham sanções a condutas temerárias dos litigantes (Regulamento 737, de 1850 e Decreto 3.084, de 1898).

O Código Civil de 1916, passou então a prever no artigo 160, inciso I, dentre as excludentes dos atos ilícitos "os praticados no exercício regular de um direito reconhecido". A partir de uma interpretação a contrariu sensu dessa regra legal, a doutrina passou a conceber e desenvolver a teoria geral do abuso do direito, inclusive como fonte de responsabilidade civil.

O Código Civil de 2002, por sua vez, abarcando a teoria do abuso do direito já amplamente difundida pela doutrina nacional com base na redação do Código anterior, houve por bem disciplinar no seu artigo 187, de forma expressa, que "também comete ato 
ilícito o titular de um direito que, ao exercê-lo, excede manifestamente os limites impostos pelo seu fim econômico ou social, pela boa-fé e pelos bons costumes”.

No campo processual, muito embora o CPC de 1973, atualmente em vigor, não se refira de forma expressa ao abuso do direito processual, como já se disse, a teoria do abuso do direito tem perfeita aplicação no âmbito do processo, diferenciando-se apenas pelos sujeitos do abuso (os sujeitos processuais) e pelo seu objeto (posições ou situações jurídicas processuais).

Nesse sentido, as condutas processuais inadequadas são, no mais das vezes, exteriorizações de abuso do direito processual (ou abuso do processo), ou seja, consistem no exercício anormal de uma posição ou situação jurídica processual, de forma contrária às finalidades públicas do processo ou daquele instrumento processual específico.

Abdo sustenta, em reforço a esse posicionamento, que praticamente todos os "comportamentos incorretos" dos sujeitos processuais consistem em atos abusivos, sendo raros os atos puramente ilícitos praticados no processo, já que quase sempre estão revestidos dos três elementos básicos do abuso: o exercício de uma situação jurídica subjetiva (poder, dever, ônus ou faculdade), a aparência de legalidade e o desvio de finalidade ${ }^{215}$.

Nesse sentido, os atos caracterizados por lei como litigância de má-fé (art. 17, CPC) e consistentes, portanto, em ilícitos processuais, são, em sua essência, hipóteses típicas de abuso do processo, que acabaram sendo positivadas pelo legislador dada a frequência com que se verificaram na experiência prática. Não se trata, pois, de ilícitos puros e simples, mas configuram, desde a origem, casos de abuso do processo.

Portanto, a conduta irregular dos sujeitos processuais, consistente em ofensa aos deveres ético-jurídicos impostos para a atuação em juízo - e, mais especificamente, em violação aos deveres de lealdade e probidade impostos pelo ordenamento processual brasileiro -, constitui uma forma de abuso do processo ${ }^{216}$, já que contraria as finalidades públicas da atividade jurisdicional (de aplicação do direito e pacificação social).

\footnotetext{
${ }^{215}$ ABDO, Helena Najjar. O abuso do processo, cit., p. 108-109.

${ }^{216}$ Nesse sentido, ou seja, enquadrando a violação do dever de lealdade processual na teoria do abuso do processo: GRINOVER, Ada Pellegrini. Abuso do processo e resistência às ordens judiciárias: o "contempt of court”. In: __ A marcha do processo. Rio de Janeiro: Forense Universitária, 2000. p. 63, DINAMARCO, Cândido Rangel. Fundamentos do processo civil moderno. 3. ed. São Paulo: Malheiros, 2000. t. 2, p. 601-602, THEODORO JÚNIOR, Humberto. Abuso do direito processual no ordenamento jurídico brasileiro: abuso dos direitos processuais, cit., p. 105; ABDO, Helena Najjar. $O$ abuso do processo, cit., p. 156-157.
} 
Além disso, muitas das condutas contrárias ao dever de lealdade consistem em atos chicaneiros e protelatórios, que buscam embaraçar a prestação dos serviços judiciários, procrastinar o andamento do processo e adiar a solução do litígio, comprometendo a garantia constitucional da razoável duração do processo, que, por sua vez, também constitui um dos objetivos da atividade jurisdicional ${ }^{217}$.

No que se refere à necessidade do elemento subjetivo (dolo ou culpa) para a caracterização do abuso do processo, a questão não é pacífica. Ao que nos parece, no entanto, a razão está com Barbosa Moreira ${ }^{218}$ e $\mathrm{Abdo}^{219}$, que defendem, em linhas gerais, que o critério subjetivo se mostra útil para identificar o desvio de finalidade em algumas situações de abuso, ao passo que em outras a própria redação do dispositivo legal deixa clara a desnecessidade de investigação do dolo ou culpa. Como exemplos da primeira hipótese estão as previsões do art. 273, II (manifesto propósito protelatório do réu) e art. 17, IV (oposição de resistência injustificada ao andamento do processo), sendo dispensável o elemento subjetivo, de outro turno, no caso do art. 17, I (dedução de pretensão contra texto expresso de lei ou fato incontroverso).

A improbidade processual ou a abusividade de um comportamento processual, por sua vez, gera a imposição de sanções ao responsável pela conduta inadequada ou abusiva.

Com efeito, a par da existência de disposições legais específicas que visam a prevenir o abuso do processo, como é o caso do art. 125, incisos II e III, do CPC, que impõem ao juiz o dever de velar pela rápida solução do litígio e de prevenir atos contrários à dignidade da justiça; do artigo 475-J, que impõe multa de $10 \%$ ao executado que não cumpre voluntariamente a sentença no prazo de 15 dias; do artigo 488, II, CPC, que exige o depósito prévio de $5 \%$ sobre o valor da causa como condição de procedibilidade da ação

\footnotetext{
${ }^{217}$ Essas condutas, muitas vezes, são adotadas de forma absolutamente ilegítima pelo próprio Estado em juízo, que é reconhecidamente um litigante contumaz e um dos grandes responsáveis pela inaceitável morosidade dos órgãos jurisdicionais. Nesse sentido, vale transcrever trecho de acórdão do STF: "Antes de mais nada, cumpre identificar os fatores reais de congestionamento que atingem o Poder Judiciário. E o principal deles reside, inequivocamente, na oposição (muitas vezes infundada) e na resistência estatal (nem sempre justificável) a pretensões legítimas manifestadas por cidadãos de boa-fé que se vêem constrangidos, em face desse inaceitável comportamento governamental, a ingressar em juízo, gerando, desse modo, uma desnecessária multiplicação de demandas contra o Poder Público. É preciso reconhecere lamentar - que o Poder Público, muitas vezes, tem assumido, em alguns casos, a inaceitável posição de improbus litigator, incidindo, com essa inadequada conduta processual, em atitudes caracterizadoras de litigância temerária, intensificando, de maneira verdadeiramente compulsiva, o volume das demandas múltiplas que hoje afetam, gravemente, a regularidade e a celeridade na efetivação da prestação da tutela jurisdional pelo próprio Estado.” (STF, 2 ${ }^{\mathrm{a}}$ t., AgRg em AgIn 246.564-0-RS, rel. Min. Celso de Mello, j. 19.10.1999, por maioria, DJ 17.12.1999).

${ }^{218}$ BARBOSA MOREIRA, José Carlos. A responsabilidade das partes por dano processual no direito brasileiro. In: Temas de direito processual: primeira série: São Paulo: Saraiva, 1988.

${ }^{219}$ ABDO, Helena Najjar. O abuso do processo, cit., p.115-122.
} 
rescisória, dentre outras, o ordenamento também prevê a imposição de sanções ao sujeito pelo descumprimento dos deveres ético-jurídicos impostos à atuação em juízo, ou seja, a responsabilidade pela improbidade processual.

A primeira delas é a reparação de danos, prevista nos artigos 16 e 18 do CPC. Os referidos dispositivos impõem ao litigante de má-fé a responsabilidade por indenizar a parte contrária pelas perdas e danos sofridas, além de arcar com a multa que venha a ser fixada pelo juiz.

As perdas e danos, na dicção dos artigos 402 e 403 do Código Civil, são compostas tanto dos danos emergentes (os prejuízos efetivamente sofridos) como dos lucros cessantes (aquilo que razoavelmente deixou de lucrar), sendo certo que ambos devem ser indenizados desde tenham por causa direta e imediata a conduta abusiva do litigante. Relembre-se aqui o exemplo já anteriormente citado da propositura de ações de conhecimento ou executivas, sem fundamento plausível, visando apenas e tão-somente frustrar negócio imobiliário. Nesse caso, constatado o abuso e os danos dele decorrentes, são perfeitamente indenizáveis tanto o prejuízo efetivo como o eventual lucro que o litigante prejudicado deixou de auferir pela inviabilização do negócio.

Observe-se que o litigante de má-fé, responsável pelos danos causados à parte contrária, não necessita ser sucumbente para incidir na responsabilização por perdas e $\operatorname{danos}^{220}$. E, havendo vários litigantes de má-fé, cada um será condenado na proporção de seu interesse na causa, ou solidariamente, se coligados para lesar a parte contrária (art. 18, $\left.\S 1^{\circ}, \mathrm{CPC}\right)$.

O credor da indenização, por sua vez, é a parte prejudicada pelo abuso cometido, podendo ser até mesmo o litisconsorte ou o assistente daquele que praticou o abuso (daí porque a doutrina sugere uma releitura do artigo 18, CPC, para abarcar a indenização à parte prejudicada e não simplesmente à parte contrária $)^{221}$. E, havendo pluralidade de prejudicados, cada um será indenizado na proporção de seu prejuízo.

Essa modalidade de responsabilização (reparação de danos) pressupõe, ainda, a prova do efetivo dano sofrido pela parte prejudicada, já que tem natureza de indenização. $\mathrm{E}$ a reparação, evidentemente, deve corresponder ao prejuízo efetivo sofrido. Assim, muito embora o artigo $18, \S 2^{\circ}$, CPC, limite o valor da indenização em $20 \%$ do valor da causa,

\footnotetext{
${ }^{220} \mathrm{Cf}$. BARBOSA MOREIRA, José Carlos. A responsabilidade das partes por dano processual no direito brasileiro, cit., p. 25.

${ }^{221}$ ABDO, Helena Najjar. O abuso do processo, cit., p. 231-232.
} 
tem-se entendido que se os prejuízos excederem esse limite poderá haver, a requerimento do prejudicado, apuração em fase de liquidação de sentença ${ }^{222}$.

Há quem sustente, ainda, que independentemente de requerimento da parte prejudicada, constatada a conduta ímproba, ainda que não comprovados danos materiais, a indenização será devida ainda assim, a título de danos morais, por ter sido o litigante "atingido no seu direito de ter um processo pautado pela probidade e, ainda, a indenização ter caráter nitidamente sancionador, ${ }^{223}$.

Outra espécie de sanção comumente aplicada em consequência da improbidade processual é a pena de multa.

De fato, são diversas as hipóteses de aplicação de multa previstas no ordenamento processual brasileiro para coibir o abuso do processo, dentre as quais: a litigância de má-fé, com multa no percentual máximo de $1 \%$ sobre o valor da causa (art. 18, CPC); a prática de ato atentatório à dignidade da justiça, com multa no percentual máximo de $20 \%$ do valor da causa (arts. 599 a 601, CPC); a oposição de embargos de declaração manifestamente protelatórios, com multa de até $1 \%$ do valor da causa, elevado a $10 \%$ em caso de reiteração (art. 538, CPC); o não cumprimento voluntário da sentença no prazo de 15 dias, com multa de $10 \%$ sobre o valor atualizado do débito (art. 475-J, CPC); a oposição de embargos à execução manifestamente protelatórios, com multa de $20 \%$ sobre o valor executado (art. 740, CPC); o descumprimento de provimento mandamental ou o embaraço ao seu cumprimento, com multa de até $20 \%$ do valor da causa (art. 14, parágrafo único, CPC); a falsa afirmação de pobreza para obter os benefícios da justiça gratuita, com multa de até 10 vezes o valor das custas judiciais (aer. $4^{\circ}, \S 1^{\circ}$ da Lei 1.060/50); a falsa alegação dos pressupostos para a efetivação da citação por edital, com multa de até $10 \%$ do valor atualizado da causa (art. 232 e 233, CPC), dentre outras.

Observa-se que, no caso brasileiro, a fixação da multa não fica ao puro arbítrio do órgão judicial, já que a própria lei prevê o limite máximo da sanção a ser imposta nas hipóteses de abuso, o que minimiza a possibilidade de excessos na determinação do valor da penalidade.

\footnotetext{
${ }^{222}$ Dinamarco acrescenta, ainda, que muitas vezes o valor da causa (até mesmo por malícia do autor) não corresponde ao efetivo valor envolvido na demanda, hipótese em que o limite de $20 \%$ estabelecido em lei deve ser aplicado sobre o valor do efetivo benefício econômico em disputa. Cf. DINAMARCO, Cândido Rangel. Instituições de direito processual civil, cit., 6. ed., v. 2, p. 265.

${ }^{223}$ OLIVEIRA, Ana Lúcia Iucker Meirelles de. Litigância de má-fé. São Paulo: Ed. Revista dos Tribunais, 2000.
} 
O beneficiário da multa, em geral, é a parte prejudicada com a conduta abusiva, como dispõe expressamente a lei na maioria dos casos, exceção feita ao caso de descumprimento do provimento mandamental ou embaraço à efetivação do provimento jurisdicional (art. 14, parágrafo único, CPC), hipóteses em que, por expressa disposição legal, o valor é revertido em favor do Estado ou da União, de acordo com a competência para julgamento do feito.

Outra sanção prevista no ordenamento, de natureza também pecuniária, consiste na chamada alteração do custo financeiro do processo, com a imposição ao litigante ímprobo das despesas processuais e dos honorários da parte prejudicada (art. 18, CPC), independentemente do resultado da demanda.

Abdo, ao tratar de forma aprofundada do assunto, cita ainda outras espécies de sanção previstas no ordenamento jurídico para o litigante que pratica abuso do processo, dentre as quais restrição de direitos (ex: condicionamento da admissibilidade do recurso ao pagamento da multa fixada por embargos protelatórios - art. 538, parágrafo único, CPC), consequências processuais impostas pelo poder diretivo do juiz (ex: antecipação da tutela por abuso do direito de defesa (art. 273, II), presunção de veracidade pela recusa de exibir documento (art. 359, CPC), imposição de medidas coercitivas (art. 461, § $4^{\circ}$ e $5^{\circ}$ ), nulidade ou inexistência do ato, sanções penais, etc ${ }^{224}$. Esse tema será retomado no Capítulo 6 infra.

Muito embora até aqui tenha se analisado a responsabilidade das partes, a verdade é que qualquer dos sujeitos da relação processual pode cometer abuso e, portanto, ser responzabilizado pelas perdas e danos daí decorrentes.

Para efeito de responsabilização por dano processual, no conceito de partes incluem-se os litisconsortes e os terceiros intervenientes no feito ${ }^{225}$, tal como o assistente, $\mathrm{o}$ opoente e o terceiro prejudicado. Também o Ministério Público, na qualidade de parte ou de fiscal da lei, possui os mesmos poderes e ônus atribuídos às partes (art. 81, CPC), razão pela qual também pode ser responsabilizado por improbidade processual.

\footnotetext{
${ }^{224}$ Ver a respeito: ABDO, Helena Najjar. O abuso do processo, cit., p. 227-248.

${ }^{225}$ Utiliza-se aqui o conceito de terceiro em sentido puramente processual. A esse respeito Dinamarco esclarece: "Terceiro é rigorosamente toda pessoa que não seja parte no processo. Todos aqueles que não são partes consideram-se, em relação àquele processo, terceiros (Liebman)... Esse é o conceito puro de parte, tão puro quanto o de parte processual e diametralmente oposto a ele. Essas ideias legitimam a afirmação de que o terceiro só o é até que intervenha: ao intervir converte-se em parte (DINAMARCO, Cândido Rangel. Instituições de direito processual civil, cit., 6. ed., v. 2, p. 380.)
} 
A situação do juiz, já mencionada no item 3.1 supra, será retomada no capítulo 6, item 6.3 infra, razão pela qual, para evitar repetições desnecessárias, remetemos o leitor àquele capítulo.

A atuação abusiva dos advogados, por sua vez, pelas peculiaridades de nosso sistema, deve ser objeto de apreciação pelo respectivo órgão de classe (Ordem dos Advogados do Brasil), responsável pela aplicação das respectivas sanções disciplinares.

Com efeito, muito embora o artigo 14, CPC, discipline os deveres das partes, de seus procuradores e de todos aqueles que de qualquer forma participam do processo, o seu parágrafo único, acrescentado pela Lei 10.358/2001, ao tratar das sanções decorrentes de atos atentatórios à dignidade da justiça, faz ressalva expressa no sentido de que " $o s$ advogados se sujeitam exclusivamente aos estatutos da OAB”.

A tradição de nosso direito, na esteira dos demais ordenamentos integrantes da civil law, repele a subordinação do procurador da parte ao poder disciplinar do órgão judiciário, o que se dá em garantia da independência da atuação do patrono, que, ao fazê-lo, exerce serviço público essencial à administração da Justiça (art. 133, CF), e também, portanto, como garantia do regular exercício da profissão ${ }^{226}$.

Ademais, entende-se que, mesmo se verificada eventual falta no exercício da representação em juízo, a parte responde perante o ex adverso, o juiz ou a parte lesada pelos atos praticados no processo pelo advogado, em razão da culpa in eligendo, decorrente da outorga do mandato ao causídico para representá-la em juízo ${ }^{227}$.

Isto se dá, evidentemente, sem prejuízo do direito de regresso da parte contra seu patrono, para ver-se ressarcida dos prejuízos que lhe tenham sido causados pela má atuação do profissional no exercício do mandato, o que poderá incluir eventual sanção pecuniária

\footnotetext{
${ }^{226}$ José Rogério Cruz e Tucci justifica a exceção realizada por lei ao tratamento do abuso cometido pelos advogados nos seguintes termos: "Inseridos, ex vi legis, no mesmo plano hierárquico, o advogado e o juiz jamais devem externar, na prática do respectivo ofício, qualquer ressentimento pessoal. Todavia, o advogado e o juiz, que são homens como quaisquer outros, têm sentimentos profundos. A experiência realmente demonstra que a formação moral e cultural dos protagonistas da justiça culmina interferindo no exercício da profissão. Não são raras as ocorrências, em época contemporânea, que revelam as dificuldades que emergem do relacionamento do advogado/juiz. É por essa razão que se justifica plenamente a exceção atinente aos advogados, uma vez que, na mão de juízes rancorosos, a inovação legislativa, se lhes fosse aplicável, acabaria sendo um instrumento de ameaça e de constrangimento para o livre exercício da advocacia." CRUZ E TUCCI, José Rogério. Repressão ao dolo processual: o novo art. 14 do CPC, cit., p. 22-23.

${ }^{227}$ Nesse sentido: ALVIM NETO, Jose Manoel de Arruda. Deveres das partes e dos procuradores no direito processual civil brasileiro (a lealdade no processo), cit., p. 18-19, BARBOSA MOREIRA, José Carlos. A responsabilidade das partes por dano processual, cit., nota 16, p. 25 e OLIVEIRA, Ana Lúcia Iucker Meirelles de. Litigância de má-fé, cit., p. 70-72.
} 
imposta à parte por litigância de má-fé, desde que comprove que a conduta adotada pelo causídico foi realizada sem a ciência e aprovação daquela.

O direito de regresso, frise-se, tem fundamento expresso nos artigos 17 e 32 da Lei 8.078/90 (Estatuto da Advocacia e da Ordem dos Advogados do Brasil), assim como no artigo 14 da Lei 8.078/90 (Código de Defesa do Consumidor), que prevêm a responsabilidade do advogado por danos causados aos seus clientes, por ação ou omissão, no exercício da advocacia.

\subsection{Aplicação da cláusula geral de boa-fé no processo civil, dever de colaboração e inadmissibilidade do comportamento contraditório - nemo potest verire contra factum proprium}

Ainda, no contexto do estudo do conteúdo ético do processo, cumpre registrar tendência doutrinária desenvolvida nos últimos anos, no sentido da aplicação da cláusula geral de boa-fé no processo civil como fonte criadora dos deveres de cooperação e colaboração e, ao mesmo tempo, como forma eficiente de prevenir e coibir condutas desleais e indevidas dos litigantes.

A boa-fé é norma de conduta universal, qualidade intrínseca do ser humano, que o leva a agir com retidão, de maneira proba e leal em seu relacionamento social, sendo a máfé um caminho anormal escolhido pelo homem ${ }^{228}$. Trata-se, portanto, de conceito éticosocial albergado pelo direito e que influencia todo o ordenamento jurídico, que tem na presunção da boa-fé um de seus pilares fundamentais.

Conforme entendimento assente da doutrina, a boa fé constitui "sobreprincípio do ordenamento jurídico, posto que paira por cima dos demais princípios jurídicos, consequentemente condiciona, determinando no espaço e no tempo, sua interpretação". ${ }^{229}$

\footnotetext{
${ }^{228}$ Rui Stoco ensina que "Estar de boa-fé e agir de boa-fé constituem estados inerentes ao ser humano. Ele nasce puro, ingênuo e absolutamente isento de maldade e perversidade. Em sua gênese, vai se transformando segundo influência dele sobre si próprio e da sociedade em que vive sobre ele, podendo manter sua condição original ou assumir comportamentos decorrentes da influência e da sua conversão. Portanto, a boa-fé constitui atributo natural do ser humano, sendo a má-fé o resultado de um desvio de personalidade." (STOCO, Rui. Abuso do direito e má-fé processual. São Paulo: Ed. Revista dos Tribunais, 2002).

${ }^{229}$ RIBEIRO, Darci Guimarães. O sobreprincípio da boa-fé processual como decorrência do comportamento da parte em juízo. Revista da Ajuris, Porto Alegre, v. 31, n. 95, p. 71-87, set. 2004.
} 
Essa influência da boa-fé sobre todo o ordenamento, no caso brasileiro, extrai-se dos próprios postulados da Constituição Federal, que tem na construção de uma sociedade livre, justa e solidária um dos objetivos fundamentais do Estado organizado, elevando assim, ao grau máximo, o dever de cooperação, solidariedade e lealdade entre os cidadãos no trato social.

A doutrina, tradicionalmente, conceitua a boa-fé sob o prisma subjetivo e objetivo. Sob o primeiro, a boa-fé é tida como "o estado de consciência ou convencimento individual de obrar em conformidade ao direito aplicável”. Já sob o prisma objetivo a boafé corresponde a um "modelo de conduta social, arquétipo ou standart jurídico, segundo o qual cada pessoa deve ajustar a sua própria conduta a esse arquétipo, obrando como obraria um homem reto: com honestidade, lealdade, probidade. „230

Nos últimos tempos, as transformações da sociedade, a complexidade dos direitos e das relações sociais e os novos conflitos verificados vêm exigindo do direito uma mudança de paradigma, razão pela qual também o princípio da boa-fé, há muito conhecido no direito ocidental, vem tomando cada vez mais contornos de objetividade ${ }^{231}$.

No direito privado brasileiro essa tendência é manifesta, sendo que a exigência da boa-fé objetiva foi consagrada de maneira inequívoca nos artigos 113, 422 e 765 do Código Civil em vigor e também nos artigos $4^{\circ}$, III e 51, IV, da Lei 80.78/90 (Código de Defesa do Consumidor).

O paradigma da boa-fé objetiva vem estabelecer novos limites para o exercício das posições nas relações jurídicas, vedando comportamentos que, embora legal ou contratualmente assegurados, não se conformam aos standarts impostos pela cláusula geral.

Nesse sentido, com base nessa cláusula geral, o ordenamento jurídico passa a não mais tolerar o exercício de posições jurídicas, ainda que pelo titular do direito ou da situação subjetiva, quando em detrimento da legítima expectativa e da confiança criada na contraparte ou mesmo diante da relevância do direito material subjacente, buscando proteger um valor mais importante em detrimento de outro, ainda que licitamente exercido $^{232}$.

\footnotetext{
${ }^{230}$ MARTINS-COSTA, Judith. A boa-fé no direito privado. São Paulo: Ed. Revista dos Tribunais, 1999.

${ }^{231}$ VINCENZI, Brunela Vieria de. A boa-fé no processo civil, cit.

${ }^{232}$ Trata-se aqui do chamado "exercício inadmissível de posições jurídicas".
} 
Observe-se que, diversamente do que decorre da teoria da responsabilidade civil, a ideia aqui não é apenas de apenar ou impor ao culpado a reparação do dano, mas sim, sempre que possível, promover a manutenção da relação jurídica, com o aproveitamento dos atos já praticados. Nesse sentido, pode-se citar como exemplo a criação jurisprudencial que, com fulcro na boa-fé objetiva, impede a resolução do contrato por inadimplemento quando verificado o adimplemento substancial ou a responsabilidade pela ruptura injustificada das negociações preliminares ${ }^{233}$.

No âmbito da atividade jurisdicional, a boa-fé processual também é regra expressa, eis que, como já visto e repisado, proceder com boa-fé é considerado dever das partes e de todo aquele que participa do processo (art. 14, CPC).

Além disso, também no processo civil, a exemplo do que ocorre nos demais ramos do direito, presume-se a boa-fé do litigante na prática dos atos processuais, o que se verifica em diversas normas expressas do ordenamento, como é o caso da presunção de veracidade da declaração de pobreza para fins de obtenção da assistência judiciária gratuita, da presunção de correção do valor atribuído à causa até prova em contrário, dentre outros.

A presunção de boa-fé na prática dos atos processuais, aliás, atende aos postulados da economia processual, já que permite impulsionar o procedimento na confiança da conduta honesta das partes, evitando paralisações desnecessárias quando não há insurgência do outro litigante ${ }^{234}$.

Por outro lado, a aplicação do princípio da boa-fé objetiva ao processo tem servido também para fundamentar a existência de deveres acessórios aos litigantes, dentre os quais, precipuamente, o de colaborar, cooperar para a realização dos escopos do processo, por meio de uma conduta processualmente adequada. Nesse sentido:

"O dever de colaboração das partes no processo civil resulta, em última análise, na aplicação da regra da boa-fé objetiva, pois esta, como criadora de deveres acessórios, impõe a cooperação das partes para o fim do processo e a realização dos resultados programados pelo direito. Em suma, não se trata de simplesmente vedar atuações abusivas ou exclusivamente resistentes ao avanço do procedimento: é algo mais, tratase de uma diligência especial que se deve entender expressamente compatível com a possibilidade de utilizar, de boa-fé, os meios e instrumentos jurídicos que são oferecidos pelo sistema. O que importa

\footnotetext{
${ }^{233}$ VINCENZI, Brunela Vieria de. A boa-fé no processo civil, cit., p. 164-167.

${ }^{234}$ MILHOMENS, Jonatas. Da presunção da boa-fé no processo civil. Rio de Janeiro: Forense, 1961. p. 6162.
} 
dizer que condutas contrárias a essa diligência especial, mesmo que não tenham o evidente propósito de obstruir a movimentação do processo, revelam a inegável falta de colaboração processual e por essa razão devem ser controladas pelo juiz e apontadas pela parte prejudicada." ${ }^{235}$

É também a boa-fé objetiva que fundamenta a inadmissibilidade de comportamento contraditório no processo, ou seja, a aplicação da regra nemo potest venire contra factum proprium, como expressão do princípio constitucional da solidariedade social e instrumento de proteção a razoáveis expectativas alheias, criadas pelo comportamento anterior do agente (e, no caso do processo, do litigante).

Schreiber, em recente monografia sobre o tema ${ }^{236}$, explicita serem pressupostos de incidência do nemo potest venire contra factum proprium: (i) o factum proprium, consistente em um comportamento originalmente livre, ao qual o ordenamento jurídico normalmente não atribui efeito vinculante ${ }^{237}$; (ii) a legítima confiança do outro na conservação do sentido objetivo desta conduta ${ }^{238}$; (iii) um comportamento contraditório do ponto de vista objetivo, ou seja, objetivamente violador da legítima confiança do outro, independentemente da intenção do agente; e (iv) o dano ou um potencial de dano oriundo da conduta contraditória.

O autor analisa, ainda, diversos exemplos de aplicação prática, pelos Tribunais brasileiros e também pela jurisprudência estrangeira, do princípio do nemo potest venire contra factum proprium no âmbito processual.

Colhendo, primeiramente, um exemplo nacional, o autor cita a Apelação Cível $\mathrm{n}^{\circ}$ 2.699/97 julgada pelo Tribunal de Justiça do Rio de Janeiro $^{239}$, que deixou de ser conhecida em virtude do comportamento contraditório da parte, que houvera pedido, reiteradas vezes, a homologação de laudo pericial que apurou os haveres, em sociedade limitada, de um sócio ora representado por seu espólio, mas que, no entanto, diante da

\footnotetext{
${ }^{235}$ VINCENZI, Brunela Vieria de. A boa-fé no processo civil, cit., p. 170.

${ }^{236}$ SCHREIBER, Anderson. A proibição do comportamento contraditório: tutela da confiança e venire contra factum proprium. 2. ed. Rio de Janeiro: Renovar, 2007.

237، (...) uma vez que a contradição de um comportamento a que o próprio ordenamento positivo já atribui força vinculante (por exemplo, um contrato ou um negócio jurídico unilateral) atrai por si só uma sanção legalmente prevista, como a responsabilidade obrigacional." SCHREIBER, Anderson. A proibição do comportamento contraditório: tutela da confiança e venire contra factum proprium, cit.

${ }^{238} \mathrm{~A}$ confiança, nesse aspecto, deve ser analisada do ponto de vista objetivo (independemente de investigação do elemento subjetivo) e de ser legítima, ou seja, deve inexistir norma legal ou contratual que autorize o comportamento reputado contraditório.

${ }^{239}$ TJRJ, Apelação Cível 2.699/97, Rel. Wilson Marques, 3.3.98, apud SCHREIBER, Anderson. A proibição do comportamento contraditório: tutela da confiança e venire contra factum proprium, cit., p. 226-228.
} 
sentença homologatória do laudo, resolveu insurgir-se por meio de recurso. Diante da frontal oposição entre os dois atos processuais, o Tribunal entendeu inadmissível a interposição do recurso.

Segundo observa Schreiber, situações como a acima descrita resolvem-se, no mais das vezes, pela invocação de figuras como a preclusão lógica, a falta de interesse de agir, etc., no entanto, sem prejuízo, vislumbra-se também de forma subjacente "um inequívoco venire contra factum proprium”, que poderia ser obstado também pela aplicação direta do princípio da boa-fé objetiva ao processo.

Da experiência portuguesa, o autor extrai um julgado do Tribunal do Trabalho de Santarém ${ }^{240}$, que rejeitou a arguição de nulidade de citação realizada em ação trabalhista, em endereço diverso da sede social da empresa, local, porém, em que a demandada, diante de provas produzidas pelo demandante, confessou manter para recepção de "outras espécies de correspondências”. A decisão prolatada, não obstante ter aludido à fraude, dolo e má-fé, foi fundamentada, de forma principal, na contradição objetiva entre os dois comportamentos da demandada: alegar nulidade da citação, por não ter recebido citação em seu endereço e, posteriormente, confessar que o endereço em que recebida a citação era por ela mantido, há anos, para fins de recepção de correspondências.

Outro interessante exemplo trazido pelo autor diz respeito ao debate, bastante atual, sobre a possibilidade de empresas públicas e sociedades de economia mista se submeterem à arbitragem. Schreiber, em interessante posicionamento, entende aplicável o princípio do nemo potest venire contra factum proprium para impedir que tais órgãos possam vir a questionar a validade da cláusula arbitral inserida em contratos por eles próprios assinados com particulares, fundados em argumentos como a indisponibilidade do interesse público, com o escopo de transferir a solução da questão para o Poder Judiciário, ou, pior ainda, anular sentença arbitral já prolatada. Nesse caso, segundo o autor, ao interesse público envolvido se contrapõe outro interesse, também público, que impõe a observância da boafé objetiva e o respeito à confiança recíproca no tráfego negocial.

No tocante aos resultados práticos da aplicação do princípio da boa-fé objetiva ao processo, a doutrina analisada sustenta a possibilidade tanto de reparação dos danos

\footnotetext{
${ }^{240}$ Tribunal de Relação de Évora, Ag. Soc. 82.97-49C, 18.11.1997, Rel. Des. Alberto da Silva Campinho, apud SCHREIBER, Anderson. A proibição do comportamento contraditório: tutela da confiança e venire contra factum proprium, cit., p. 240-242.
} 
causados aos prejudicados, como, quando possível - o que parece mais eficaz - o uso da boa-fé objetiva para impedir o ato incoerente (ou ao menos seus efeitos) ${ }^{241}$.

Assim, diante de tudo o que foi analisado ao longo deste capítulo a respeito do conteúdo ético do processo, é de se concluir que os atuais paradigmas do processo e os influxos da visão publicista e cooperativa estão a exigir das partes e de todos aqueles que atuam em juízo uma conduta processual adequada, condizente com a dignidade desse instrumento público de solução de conflitos, e, ao mesmo tempo, do órgão jurisidicional, uma postura mais atenta, participativa e enérgica com relação à identificação e coibição dos comportamentos desleais, desonestos e protelatórios dos litigantes no processo, que tanto obstaculizam o regular trâmite processual e o alcance de seus objetivos. Mais do que isso, o ordenamento jurídico brasileiro já dispõe de arsenal suficiente tanto para a coibição desses comportamentos reprováveis como para o sancionamento do responsável, de sorte a, a um só tempo, educar os jurisdicionados e afastar cada vez mais essa prática tão arraigada no cotidiano forense.

É necessário, contudo, não perder de vista que esse ativismo exigível do julgador na qualidade de diretor do processo não pode transformar o processo em algo ditatorial, nem o exercício desses poderes-deveres do juiz pode se dar ao arrepio das garantias constitucionais do contraditório, da ampla defesa, do acesso à justiça. Como bem pondera Dinamarco a esse respeito, um sistema radical de sanções acabaria produzindo efeito inverso ao desejado, inibindo o litigante bem intencionado e, até mesmo, o expondo aos expedientes abusivos do malicioso ${ }^{242}$. Daí a necessidade de aplicação da razoabilidade na análise desses comportamentos.

Além disso, toda e qualquer reprimenda ao litigante não pode prescindir da prévia oportunidade de manifestação e, se o caso, produção das provas necessárias ao exercício do seu direito de defesa, cujas razões devem ser devidamente analisadas pelo julgador em decisão devidamente fundamentada.

\footnotetext{
${ }^{241}$ Nesse sentido Brunela Vieira de Vincenzi acentua: "parece possível impedir o exercício de posições inadmissiveis, sem cominar sanções ou multas, mas por meio de atos do juiz que impeçam a prática ou a continuidade de determinada conduta da parte, seja por meio de 'ameaças', seja com a inversão do tempo no processo, ou até com a inversão de certos ônus (como acontece na revelia) ao litigante que abusa da confiança depositada nele pelo Estado, ou com a perda de direitos processuais como consequência da violação á regra da boa-fé." (in, A boa-fé no processo civil, cit., p. 172).

${ }^{242}$ DINAMARCO, Cândido Rangel. Instituições de direito processual civil, cit., 6. ed., v. 2, p. 266.
} 


\subsection{Dever de colaboração no Projeto do Novo Código de Processo Civil (PLS no 166/2010)}

Para finalizar este Capítulo, cumpre apenas registrar que o Projeto de Código de Processo Civil (PLS n 166/2010), já aprovado pelo Senado Federal e atualmente em tramitação na Câmara dos Deputados (PL 8.046/2010), traz expressa previsão do dever de colaboração aqui tantas vezes repetido.

Como é de conhecimento geral, no ano de 2009, a Presidência do Senado Federal, por meio dos atos $n^{\circ} 379$ e 411, instituiu uma Comissão de Juristas para a elaboração de um Anteprojeto de Código de Processo Civil, presidida por Luiz Fux, então ministro do Superior Tribunal de Justiça e atualmente Ministro do Supremo Tribunal Federal, e que teve como relatora-geral a professora Teresa Arruda Alvim Wambier.

Realizados os estudos iniciais e delimitadas as proposições temáticas sobre as quais gravitariam as alterações legislativas, relativamente ao estatuto processual atualmente em vigor, seguiu-se então a realização de audiências públicas nos mais diversos estados brasileiros a fim de debater a proposta legislativa com a sociedade e, notadamente, com a comunidade jurídica de todo o país.

Em 08.05.2010 foi então entregue pela Comissão o Anteprojeto ao presidente do Senado Federal, Senador José Sarney, que passou a tramitar no Senado como Projeto de Lei $n^{\circ} 166 / 2010$.

O Projeto do Novo CPC é constituído por inúmeras normas que evidenciam e reforçam o dever de colaboração do Estado para com o jurisdicionado e deste com aquele no curso do processo. A título exemplificativo, podem ser citados: o artigo $8^{\circ}$ (que impõe o dever das partes de contribuir para a rápida solução da lide, colaborando na identificação das questões de fato e de direito e abstendo-se de provocar incidentes procrastinatórios), os artigos $9^{\circ}, 10^{\circ}, 110$, parágrafo único e 463, parágrafo único (que impõem a prévia manifestação das partes antes de qualquer decisão, ainda que se trate de matéria de ordem pública, como é o caso da prescrição e da decadência), os artigos 301 e $858, \S 1^{\circ}$ (que impõem a abertura de oportunidade à parte de sanar irregularidade antes da extinção do processo ou a julgamento do recurso), dentre outros.

O projeto de lei traz ainda uma previsão geral do dever de colaboração em seu artigo $5^{\circ}$, assim redigido: 
"As partes têm direito de participar ativamente do processo, cooperando entre si e com o juiz e fornecendo-lhe subsídios para que profira decisões, realize atos executivos e determine a prática de medidas de urgência."

Em que pese a relevância de uma previsão genérica, como verdadeira norma principiológica, do dever de colaboração no Projeto do Novo CPC, Marinoni e Mitidiero fazem crítica à redação do dispositivo, por induzir a um entendimento de que se trataria de uma exigência de colaboração entre as partes no processo, sendo que, no entender dos citados professores, "é a própria estrutura do sistema adversarial ínsita ao processo contencioso que repele a ideia de colaboração entre as partes" 243.

De efeito, como já tantas vezes repetido ao longo do estudo, a colaboração exigida na concepção contemporânea do direito processual - e que, no caso brasileiro, tem raiz constitucional - consiste numa colaboração das partes com o juiz e deste com aquelas para que sejam atingidas as finalidades do processo, a exigir um juiz ativo, no centro da controvérsia, e a participação também ativa das partes, ensejando uma relação mais equilibrada entre o juiz e as partes no desenvolvimento do processo.

A inovação legislativa, proposta no ensejo do Projeto do Novo CPC brasileiro, aliás, acompanha a tendência de outros ordenamentos processuais estrangeiros.Veja-se, nesse sentido, que a ideia de colaboração no processo também está presente de maneira expressa no art. 266 do Código de Processo Civil português, que, na redação que lhe deram os Decretos-leis 329-A/95 e 180/96, assim preceitua:

\footnotetext{
"1-Na condução e intervenção no processo, devem os magistrados, os mandatários judiciais e as próprias partes cooperar entre si, concorrendo para se obter, com brevidade e eficácia, a justa composição do litígio. 2- O juiz pode, em qualquer altura do processo ouvir as partes, seus representantes ou mandatários judiciais, convidando-os a fornecer os esclarecimentos sobre a matéria de facto ou de direito que se afigurem pertinentes, e dando-se conhecimento à outra parte dos resultados da diligência. 3 - As pessoas referidas no número anterior são obrigadas a comparecer sempre que para isso forem notificadas e a prestar os esclarecimentos que lhe forem pedidos, sem prejuízo do disposto no n. 3 do artigo 519. 4- Sempre que alguma das partes alegue justificadamente dificuldade séria em obter documento ou informação que condicione o eficaz exercício da faculdade ou o cumprimento de ônus ou dever processual, deve o juiz, sempre que possível, providenciar pela remoção do obstáculo."
}

\footnotetext{
${ }^{243}$ MARINONI, Luiz Guilherme, MITIDIERO, Daniel. O Projeto do $C P C$ : críticas e propostas. São Paulo:
} Ed. Revista dos Tribunais, 2010. p. 72-74. 
Disposições semelhantes estão contidas, também, no art. 16 do Nouveau Code de Procedúre Civile francês ${ }^{244}$ e no $§ 139$ da Zivilprozessordenung alemã ${ }^{245}$, embora aqui sem uma menção expressa à ideia de colaboração.

Feitas essas considerações e fixadas as premissas teóricas de nosso estudo, a partir do próximo capítulo passaremos a analisar então, propriamente, a influência dessas concepções atuais do processo civil brasileiro no papel desenvolvido pelo juiz e pelas partes na atividade probatória.

\footnotetext{
${ }^{244}$ Reza o art. 16 do Nouveau Code de Procedúre Civile francês: "Le juge doit, en touts circonstances, faire observer et observer lui-même le principe de la contradiction. Il ne peut retenir, dans sá décision, les moyens, les explications et les documents invoques ou produits par le parties que si celles-ci ont été à même d'en débattre contradictoirement. Il ne peut fonder sa décicion sur les moyens de droit qu'il a relevés d'office sans avoir au préalable invité les parties à presenter leurs observations."

${ }^{245}$ Reza o $§ 139$ da Zivilprozessordenung alemã, na tradução de Carlos Alberto Alvaro de Oliveira: "1 - O órgão judicial deve discutir com as partes, na medida do necessário, os fatos relevantes e as questões em litígio, tanto do ponto de vista jurídico quanto fático, formulando indagações, com a finalidade de que as partes esclareçam de modo completo e em tempo suas posições concernentes ao material fático, especialmente para suplementar referências insuficientes sobre fatos relevantes, indicar meios de prova, e formular pedidos baseados nos fatos afirmados. 2 - O órgão judicial só poderá apoiar sua decisão numa visão fática ou jurídica que não tenha a parte, aparentemente, se dado conta ou considerado irrelevante, se tiver chamado a sua atenção para o ponto e lhe dado oportunidade de discuti-lo, salvo se se tratar de questão secundária. O mesmo vale para o entendimento do órgão judicial sobre uma questão de fato ou de direito que divirja da compreensão de ambas as partes. 3 - O órgão judicial deve chamar a atenção sobre as dúvidas que existam a respeito das questões a serem consideradas de ofício. 4 - As indicações conforme essas prescrições devem ser comunicadas e registradas nos autos tão logo seja possível. Tais comunicações somente podem ser provadas pelo registro nos autos. Só é admitida contra o conteúdo dos autos prova da falsidade. 5 Se não for possível a uma das partes responder prontamente a uma determinação judicial de esclarecimento, o órgão judicial poderá conceder um prazo para posterior esclarecimento por escrito." (MITIDIERO, Daniel. Colaboração no processo civil: pressupostos sociais, lógicos e éticos, cit., nota 81, p. 76).
} 


\section{DIVISÃO DE TRABALHO ENTRE JUIZ E PARTES NA ATIVIDADE PROBATÓRIA}

\subsection{O papel do juiz e das partes na instrução processual}

Como já visto, o processo civil brasileiro, na concepção contemporânea aqui estudada, é embasado no diálogo judicial e na ampla colaboração de todos aqueles que participam do processo, de forma a se atingir os escopos social e político da jurisdição.

E, para o alcance desses objetivos, o ordenamento jurídico estabelece uma determinada "divisão de trabalho" entre o órgão jurisdicional e as partes em todo o iter procedimental, no qual se inclui a fase probatória, com o reconhecimento, de um lado, da amplitude dos poderes instrutórios do juiz e, de outro, com o fortalecimento das posições das partes, garantindo-lhes, através do exercício pleno do contraditório, participação ativa na formação do convencimento judicial.

É justamente sobre essa divisão de trabalho na instrução processual que dedicaremos as próximas linhas de nosso estudo.

\subsubsection{Juiz: tendência ampliadora dos poderes instrutórios}

Como já se viu, o ativismo judicial, caracterizado por uma postura participativa e comprometida do juiz com o resultado da atividade jurisdicional e com a qualidade de suas decisões - o que tem reflexos diretos na atividade probatória - é tido como uma tendência irreversível e componente essencial do processo civil atual.

Não se propugna, entretanto, o reconhecimento de ilimitados poderes instrutórios do juiz, com o amesquinhamento das garantias processuais ou a substituição do papel das partes no processo. Muito ao reverso, o que caracteriza o processo de cunho colaborativo é o reconhecimento dos poderes instrutórios do juiz (limitado, evidentemente, à observância das regras legais e aos limites objetivos da demanda definidos pelas partes), simultaneamente com o chamado ativismo das partes, por meio do efetivo exercício do contraditório. 
Oliveira assinala que a questão assim colocada, ou seja, de equilíbrio na posição do juiz e das partes, “deverá substituir com vantagem a oposição e o confronto, dando azo ao concurso das atividades dos sujeitos processuais, com ampla colaboração tanto na pesquisa dos fatos quanto na valorização da causa"246.

Nesse contexto, é importante verificar de que maneira vem sendo superados pela doutrina os tradicionais óbices levantados à admissão do incremento dos poderes diretivos e instrutórios do juiz.

O primeiro obstáculo usualmente apontado pela doutrina refratária (ou, ao menos, restritiva) à iniciativa probatória do juiz diz respeito a uma suposta infringência ao princípio dispositivo.

Isso porque na ótica tradicional, estando em discussão direitos disponíveis, caberia somente às partes definir o rumo do processo e, em particular da atividade probatória, vedando-se a iniciativa judicial, inclusive probatória, que, por esse ângulo de análise, caracterizaria interferência indevida do juiz na esfera de direitos do interessado.

No entanto, a emancipação da ciência processual da relação jurídica material possibilitou novo enfoque sobre a questão, o que gerou conseqüências no reconhecimento dos poderes instrutórios do juiz.

A doutrina passou a distinguir o exercício do direito de ação, com a propositura da demanda e fixação do objeto controvertido - o que cabe com exclusividade às partes litigantes - da direção interna do processo, que incumbe ao juiz e nenhuma relação guarda com a natureza dos direitos envolvidos, escapando à disponibilidade das partes. Cappelletti $^{247}$, distinguindo a direção material e a direção formal do processo, esclarece caber esta última exclusivamente ao juiz.

Justamente por essa razão, Cintra, Grinover e Dinamarco passaram a designar de "princípio da demanda", "princípio da ação" ou "princípio da disponibilidade" a liberdade da parte de dar início ao processo, retirando-a do conceito de "princípio dispositivo", reservado para os atos formalizados no interior do processo $^{248}$.

\footnotetext{
${ }^{246}$ OLIVEIRA, Carlos Alberto Alvaro de. Do Formalismo-valorativo no confronto com o formalismo excessivo. São Paulo: Saraiva, 2010. p. 62.

${ }^{247}$ CAPPELLETTI, Mauro. La testimonianza della parte nel sistema della'oralità. Milano: Giuffrè, 1974. p. 71.

${ }^{248}$ GRINOVER, Ada Pellegrini; CINTRA, Antônio Carlos de Araújo; DINAMARCO, Cândido Rangel. Teoria geral do processo. cit., p. 63 e seg.
} 
Bedaque, por sua vez, desenvolvendo o raciocínio, entende que a denominação "princípio dispositivo" deve ser reservada aos "reflexos que a relação de direito material disponível possa produzir no processo". Tais reflexos, por sua vez, referem-se apenas à própria relação de direito material. Assim, tratando-se de direito disponível, as partes têm liberdade para dele dispor, através de atos processuais (renúncia, desistência, reconhecimento do pedido, etc.), não podendo o juiz se opor a tais atos, justamente pela natureza do direito material envolvido, sob pena de indevida intromissão na autonomia privada das partes. No entanto, se o ingresso em juízo, a limitação do pedido e causa de pedir são privados, o modo como se exerce a jurisdição não o é, regendo-se por normas de direito público, justamente em razão dos escopos da jurisdição, já anteriormente $\operatorname{tratados}^{249}$.

Também para Taruffo ${ }^{250}$ e Echandia ${ }^{251}$, o princípio guarda relação apenas com a propositura da demanda e fixação do objeto do processo, mas não com a atividade instrutória. Barbosa Moreira, por sua vez, é enfático ao defender a inexistência de correlação entre a natureza do direito controvertido e os poderes instrutórios do juiz:

"Dir-se-á que os litigantes hão de conservar o poder de dispor de seus direitos. Ora, ninguém é forçado a invocar um direito em juízo, nem, por conseguinte, a alegar o fato de que ele se originaria. Mas aí cessa o poder de disposição. Se a parte alega o fato, é porque quer que dele se extraia esta ou aquela consequiência jurídica. Impedir o juiz de fazer o possível observados sempre os limites do pedido e causa de pedir - para certificarse de que o fato alegado realmente ocorreu (ou não ocorreu) será atitude manifestamente contraditória. Caso lhe resulte inconveniente, por tal ou qual motivo, a averiguação, tem ainda o litigante, no âmbito das relações jurídicas disponíveis, a opção de renunciar ao direito postulado, e com isso barrar o caminho à cognição judicial. $\mathrm{O}$ que de jeito nenhum se afigura razoável é pretender a tutela jurisdicional e, ao mesmo tempo,

\footnotetext{
${ }^{249}$ Nesse sentido: "Assim fácil concluir o seguinte: o princípio dispositivo diz respeito apenas às limitações do juiz no tocante aos atos de disposição das partes. E esse é um verdadeiro limite à atividade do juiz, ou seja, diante de atos que expressem declarações de vontade das partes como a transação, a renúncia ou o reconhecimento jurídico do pedido do autor, compete ao juiz analisar apenas os aspectos formais, ou seja, verificar se presentes os requisitos necessários à efetividade da declaração de vontade, restando impedido, por exemplo, de opor-se à homologação do acordo por motivo de ordem não formal se o direito for disponível, a atividade é meramente deliberatória, tanto que entendemos que essa atividade caracteriza falsa sentença de mérito." (AMENDOEIRA JUNIOR, Sidnei. Poderes do juiz e tutela jurisdicional: a utilização racional dos poderes do juiz como forma de obtenção da tutela jurisdicional efetiva, justa e tempestiva, cit., p. 73).

${ }^{250}$ TARUFFO, Michele. Poderes probatórios de las partes y del juez en Europa. Revista Iberoamericana de Derecho Procesual, Buenos Aires, n. 10, 2007.

${ }^{251}$ DEVIS ECHANDÍA, Hernando. Teoria general de la prueba judicial. 5. ed. Buenos Aires: Zavalia, 1981. t. 2.1981.
} 
objetar a que o juiz se muna dos elementos necessários para verificar se deve ou não presta-la nos termos requeridos ." 252

Em síntese, segundo esse entendimento, a natureza da relação jurídica controvertida tem relevância apenas para aferir-se a maior ou menor disponibilidade sobre o direito material envolvido, mas não afeta a estrutura interna do processo, tampouco a atividade instrutória do juiz.

Yarshell $^{253}$, ao tratar do assunto, reconhece que, interessando as provas também ao Estado, como meio de propiciar a solução da controvérsia, não se pode negar ao juiz o poder de iniciativa instrutória. Pondera, todavia, que essa constatação não é suficiente para desvincular por completo da relação de direito material a forma e intensidade dos poderes instrutórios do juiz.

O autor lembra ainda que, tratando-se de direito indisponível, o ordenamento não admite a presunção de veracidade dos fatos, mesmo diante de revelia e não impugnação especificada (art. 320, II). Assim, diante da inescusável ligação entre poderes instrutórios do juiz e ônus da prova das partes (subjetivo), já anteriormente tratados, chega à conclusão de que o ordenamento jurídico, nesse caso, além de não retirar o ônus da prova do autor, ainda atribui poder instrutório ao juiz.

No caso de direitos disponíveis, todavia, segundo ele, o tratamento jurídico é diverso, pois só se abrirá a instrução se houver elementos que coloquem em dúvida a presunção que decorre da confissão ficta ou se o fato alegado não apresentar verossimilhança.

Assevera, no entanto, que optando o juiz por exercer poderes instrutórios mesmo em lide que verse sobre direitos patrimoniais disponíveis, não haverá error in procedendo nessa conduta. O que não há, todavia, segundo o autor, é o dever de assim agir, sendo que a "a disponibilidade do direito material autoriza que o juiz minimize sua iniciativa em

\footnotetext{
${ }^{252}$ BARBOSA MOREIRA, José Carlos. O neoprivatismo no processo civil, cit., p. 97-98. Em outro texto de sua autoria, o professor, com a costumeira precisão e perspicácia, traz interessante analogia entre o litigante e o enfermo submetido a tratamento hospitalar, pois, tal como no processo, se por um lado cabe ao doente optar ou não por internar-se em hospital, a partir de sua internação tem de se sujeitar às disposições do regulamento, não podendo limitar a atividade do médico nem determinar seu modo de atuação na investigação da doença e prescrição dos medicamentos adequados à cura. Cf. BARBOSA MOREIRA, José Carlos. Os poderes do juiz na direção e instrução do processo. In: Temas de direito processual: $4^{\mathrm{a}}$ série. São Paulo: Saraiva, 1989. p. 45-51.

${ }^{253}$ YARSHELL, Flávio Luiz. Antecipação da prova sem o requisito da urgência e direito autônomo à prova. cit., p. 118 e ss.
} 
troca de maior atuação dos interessados ou, diante da inércia, do julgamento conforme as regras de distribuição do ônus da prova" 254 .

Puoli, nessa mesma linha de entendimento, ressalta, com propriedade, que essa concepção atende à própria realidade do cotidiano forense, não sendo possível fechar os olhos a essa realidade fática e querer que o juiz tenha em todos os casos o mesmo grau de participação, estudo e aplicação, o que, além de utópico e impraticável, poderia, inclusive, repercutir negativamente no tempo do processo. Nesse sentido, defende a existência de uma relação de proporcionalidade que deve haver entre o grau de atuação do magistrado e a disponibilidade do interesse envolvido ${ }^{255}$.

Como exemplo, cita a pena de revelia, aplicável apenas a lides que versam sobre direitos disponíveis. Nesses casos, se, por um lado, é entendimento assente que a revelia somente deve ser aplicada se os fatos narrados pelo autor guardarem um mínimo de plausibilidade, de verosimilhança, por outro, defende o autor que essa possibilidade de questionar a verossimilhança dos fatos não deve ser levada a extremos pelo juiz, considerando que a regra legal é a presunção de veracidade.

Outro exemplo citado pelo autor diz respeito às relações de consumo. Segundo seu entendimento, o grau de atuação do magistrado deve ser diverso para os casos de demanda coletiva ou individual, reservando-se à primeira, por sua alta relevância social, os maiores esforços e empenho do juiz no esclarecimento dos fatos, de forma a propiciar a solução justa do litígio.

O segundo obstáculo usualmente levantado à amplitude dos poderes instrutórios do juiz relaciona-se com o princípio da imparcialidade do julgador. Para parcela da doutrina, o juiz, ao determinar de ofício as provas que entende necessárias ao esclarecimento dos fatos acabaria comprometendo sua imparcialidade.

Frederico Marques ${ }^{256}$ argumenta que, embora dotando-o de poderes instrutórios, a própria legislação teria afastado ao máximo o julgador dessa atividade de forma a evitar comprometer sua imparcialidade. Liebman, nesse mesmo sentido, pondera que " $a$ imparcialidade do juiz corre o risco de ficar comprometida quando deve julgar com base

\footnotetext{
${ }^{254}$ YARSHELL, Flávio Luiz. Antecipação da prova sem o requisito da urgência e direito autônomo à prova. cit., p. 124-125.

${ }^{255}$ PUOLI, José Carlos Baptista. Os poderes do juiz e as reformas do processo civil, cit., p. 27.

${ }^{256}$ MARQUES, José Frederico. Instituições de direito processual civil. Rio de Janeiro: 1958. v. 1 e v. 2.
} 
numa prova por ele próprio escolhida e por sua iniciativa realizada no processo ${ }^{257}$,. Para o conceituado jurista italiano, haveria incompatibilidade psicológica entre as funções de investigar e julgar, sendo essa a razão pela qual o juiz, ao buscar determinada prova, estaria irremediavelmente contaminado com o fato que por ela se pretenderia $\operatorname{provar}^{258}$.

Dinamarco, embora condene a figura do "juiz espectador" e reconheça o poder de iniciativa probatória conferido pelo artigo 130 do Código de Processo Civil, alerta para o risco de que o exercício dos poderes instrutórios, no limite, leve à quebra da imparcialidade. Sobre a diferença entre imparcialidade e indiferença, no entanto, assim pontua Dinamarco:

"o juiz moderno compreende que só se lhe exige imparcialidade no que diz respeito à oferta de iguais oportunidades às partes e recusa a estabelecer distinções em razão das próprias pessoas ou reveladoras de preferências personalíssimas. Não se lhe tolera, porém, a indiferença." ${ }^{259}$.

Gomes, entendendo que não há conflito entre iniciativa instrutória judicial e imparcialidade, destaca que esta última deve ser entendida como a predisposição da qual o magistrado se sente imbuído a dar razão a quem merece, segundo o direito vigente ${ }^{260}$. No entanto, imparcialidade não significa neutralidade, pois para realizar a justiça, precisa se aproximar ao máximo da verdade e para tanto não pode depender exclusivamente das provas requeridas pelas partes ${ }^{261}$.

Para Taruffo ${ }^{262}$, em contraposição ao pensamento de Liebman ${ }^{263}$, a garantia da imparcialidade decorre da exigência de contraditório efetivo, de fundamentação da decisão e da previsão do duplo grau de jurisdição, com o que se possibilita o controle das decisões pela instância superior.

\footnotetext{
${ }^{257}$ LIEBMAN, Enrico Tullio. Fondamento del principio dispositivo: problemi del processo civile. Milano: Morano, 1962. p. 13 e ss.

${ }^{258}$ Entre nós, assim também entendem Moacyr Amaral Santos (SANTOS, Moacyr Amaral. Primeiras linhas de direito processual civil, cit., v. 2, p. 79), Humberto Theodoro Júnior (Curso de direito processual civil. 39. ed. Rio de Janeiro: Forense, 2003. v. 1, p. 28) e Arruda Alvim (Manual de direito processual civil. 15. ed. rev. atual. e ampl. São Paulo: Ed. Revista dos Tribunais, 2012. p. 230).

${ }^{259}$ DINAMARCO, Cândido Rangel. A instrumentalidade do processo, cit., p. 231.

${ }^{260}$ Também nesse sentido José Carlos Barbosa Moreira afirma a imparcialidade "bem compreendida, não exclui no órgão judicial a vontade de decidir com justiça, e portanto a de dar ganho de causa à parte que tenha razão.” BARBOSA MOREIRA, José Carlos. Os poderes do juiz na direção e instrução do processo, cit.

${ }^{261}$ GOMES, Sérgio Alves. Os poderes do juiz na direção e instrução do processo civil, cit., p. 256.

${ }^{262}$ TARUFFO, Michele. Poderes probatórios de las partes y del juez en Europa. cit, p. 482.

${ }^{263}$ LIEBMAN, Enrico Tullio. Fondamento del principio dispositivo: problemi del processo civile, cit., p. 13 e ss.
} 
Barbosa Moreira ${ }^{264}$ relembra, por sua vez, que a atividade instrutória do juiz somente deve incidir sobre os fatos previamente delimitados pelas partes, sendo-lhe vedada a iniciativa investigatória para além desses limites, o que impede o juiz, por exemplo, de acolher o pedido invocando fato diverso do alegado pela parte, ainda que esteja convencido de sua ocorrência e da suficiência para produzir o resultado jurídico pretendido.

Além disso, ao argumento do risco de perda da imparcialidade do julgador, Barbosa Moreira responde que o juiz, ao determinar a produção de prova ex officio, não toma partido de um dos litigantes, pois não sabe de antemão qual o resultado que dela advirá, ou seja, a quem irá favorecer ${ }^{265}$. Além disso, sustenta que, a supor-se parcial o juiz por ordenar ex officio a realização da prova, beneficiando a parte a quem ela resulte favorável, ter-se-ia que reputá-lo também parcial ao deixar de realizá-la, eis que a falta da prova beneficiará a quem ela resultaria desfavorável, caso realizada.

Em nosso entender, a parcialidade ou mesmo a excessiva influência de aspectos subjetivos sobre a decisão do juiz é risco inerente à atividade jurisdicional e que somente pode ser obviado, ou em grande parte amenizado, pela rigorosa observância do contraditório e da fundamentação das decisões, com o que se oportuniza às partes não apenas participar da formação do conjunto probatório, fonte da cognição judicial, mas também de tomar ciência dos fundamentos da decisão, com o que poderão questionar o seu acerto perante o órgão de instância superior, uma vez assegurado o duplo grau de jurisdição.

A par disso, resguardada a sua imparcialidade, exige-se do juiz atual que seja realmente ativo na busca da melhoria da qualidade da tutela jurisdicional a ser concedida.

Outro ponto geralmente questionado no tocante à ampliação dos poderes instrutórios do juiz - correlato ao tema tratado no item precedente - diz respeito a uma

\footnotetext{
${ }^{264}$ BARBOSA MOREIRA, José Carlos. O juiz e a prova, cit., p. 181.

${ }^{265}$ Ilustrando o argumento, Sidnei Amendoeira Júnior assim exemplifica: “O juiz, mandando produzir a prova está vinculado ao seu resultado concreto. Assim, por exemplo, opostos embargos à execução e deixando o devedor/embargante de requerer prova pericial contábil para demonstrar se houve ou não a cobrança de juros capitalizados, pode perfeitamente o juiz, percebendo esse fato, determinar que se realize essa prova. O juiz aqui não está defendendo o devedor, mas, ao contrário, está apenas possibilitando a si mesmo contar com um instrumento muito mais efetivo para o julgamento da demanda, ampliando seu próprio conhecimento sobre a questão. Vale lembrar que, ao ser produzida essa perícia, ao credor/embargado será concedido o contraditório pleno, podendo impugnar a forma de realização da mesma e impugnar seu resultado, meios e conclusões. Ademais, é possível imaginar que, finda a perícia, chegue o Expert à conclusão de que nunca houve capitalização de juros, de modo que o juiz fatalmente julgará improcedentes os embargos do devedor. Se não o fizer, terá que motivar sua decisão, o que permitirá ao credor, visivelmente prejudicado, a via recursal.” (AMENDOEIRA JUNIOR, Sidnei. Poderes do juiz e tutela jurisdicional: a utilização racional dos poderes do juiz como forma de obtenção da tutela jurisdicional efetiva, justa e tempestiva, cit., p. 70.
} 
possível incompatibilidade desses poderes com as garantias processuais das partes, especialmente a garantia de tratamento isonômico dos litigantes.

Isso porque o juiz, ao determinar as provas de ofício, estaria se imiscuindo em atividade que é de interesse das partes, cuja defesa técnica já é regularmente exercida por profissional habilitado, com o que o ordenamento jurídico garante, juntamente com a observância das demais garantias processuais, a igualdade entre os litigantes.

Para a doutrina defensora de uma postura ativa do juiz na direção e instrução do feito, todavia, a igualdade meramente formal dos litigantes não atende os fins sociais do processo. Nesse passo, a iniciativa instrutória do juiz seria um importante instrumento para corrigir a desigualdade técnica e econômica muitas vezes verificada no plano prático entre os litigantes, de modo a evitar que ela possa repercutir no resultado do processo ${ }^{266}$.

Defende Barbosa Moreira, ao tratar do tema, que o litigante munido de recursos, com condição de contratar melhor advogado, goza de vantagem capaz de desequilibrar os pratos da famosa balança da justiça, distorcendo a perspectiva dos fatos controvertidos, o que poderá redundar reflexos diretos na decisão a ser proferida caso o julgador seja reduzido a mero expectador, competente apenas a assegurar a observância de certas regras do jogo $^{267}$. Esse resultado, para ele, causa repulsa a todo jurista que entende a verdade e justiça como ingredientes necessários à composição judicial dos litígios ${ }^{268}$.

Teresa Wambier, também nesse mesmo sentido pondera que:

"Diante de um quadro em que se tem em conta a problemática do acesso à justiça, tem-se necessariamente, como dado indiscutível, a eventual e até freqüente condição de desigualdade que possa haver entre os litigantes.

O juiz, nesse contexto, seria parcial se assistisse inerte, como um expectador a um duelo, ao massacre de uma das partes, ou seja, se

\footnotetext{
266“"as desigualdades econômicas e culturais são capazes, quando incontroladas, de conduzir o processo à produção de resultados distorcidos em razão de insuficiências probatórias resultantes da desídia daquele que não se defendeu melhor porque não pôde; e, por expressa determinação legal, o juiz tem o dever de promover o equilíbrio das partes no processo, assegurando aos litigantes a paridade em armas que o princípio isonômico exige (CPC, art. 125, inc. I- supra nn 82 e 511). Para esse fim e para a efetividade da garantia constitucional da ampla defesa, há situações em que a intervenção do juiz na busca e produção dos meios de prova se mostra vital. Sua intervenção é importante, ainda, quando as partes se valem do processo com o fim de obter resultados ilegais (art. 17, inc. III) como a fraude à lei ou embuste a terceiros.” (DINAMARCO, Cândido Rangel. Instituições de direito processual civil. 6. ed. São Paulo: Malheiros Ed., 2009. v. 3, p. 52-53).

${ }^{267}$ BARBOSA MOREIRA, José Carlos. O neoprivatismo no processo civil, cit.

${ }^{268}$ E prossegue: "se assim não for, que necessidade haverá de movimentar - com inevitável dispêndio de tempo, energias e recursos financeiros - a máquina judiciária? Será preferível confiar a sorte do pleito a algo mais simples, barato e rápido, como uma rinha de galos.” (BARBOSA MOREIRA, José Carlos. O neoprivatismo no processo civil, cit., p. 100-101).
} 
deixasse de interferir para tornar iguais, partes que são desiguais. A interferência do juiz na fase probatória, vista sob este ângulo, não o torna parcial. Ao contrário, pois tem a função de impedir que uma das partes venha a vencer o processo, não porque tenha o direito que assevera ter, mas porque é economicamente mais favorecida que a outra. A circunstância de uma das partes ser hipossuficiente pode levar a que não consiga demonstrar e provar o direito que efetivamente tem. E o processo foi concebido para declarar, lato sensu, o direito que uma das partes tenha, e não para retirar direitos de quem os têm ou de dá-los a quem não os têm. ${ }^{269}$

Dinamarco $^{270}$, ao lecionar sobre a iniciativa instrutória do juiz aduz que a fórmula do desejável equilíbrio entre o modelo dispositivo e inquisitivo consiste em prosseguir reconhecendo a estática judicial como regra geral, devendo o juiz tomar a iniciativa probatória em certos casos. E, dentre as hipóteses citadas como legitimadoras da iniciativa instrutória do juiz está, justamente, os casos em que o magistrado verificar que "a omissão é fruto da pobreza, de deficiências culturais das partes ou da insuficiência de patrocínio que lhes está ao alcance (especialmente em casos de assistência judiciária)”.

Parece-nos, de fato, bastante seguro o caminho indicado por Dinamarco, no sentido de que, versando o litígio sobre direitos disponíveis, a prova ex officio se justificaria em caso de manifesta desigualdade econômica, técnica ou cultural entre as partes (evidentemente, desde que tal fato traga desigualdade processual notória entre os litigantes) e também, ao nosso ver, nos casos em que, reputando o juiz inverossímeis os fatos narrados, os próprios elementos dos autos evidenciem ou insinuem a existência de provas não exploradas pelas partes, mas relevantes para o processo.

Por fim, na análise do tema do reconhecimento dos poderes instrutórios do juiz, geralmente é apontado como óbice a existência de regras legais sobre distribuição do ônus da prova, as quais seriam violadas por meio do exercício do poder instrutório do juiz.

Segundo nosso entendimento, no entanto, não há conflito entre poderes instrutórios do juiz e as regras legais de distribuição do ônus da prova, já que estas últimas apenas devem ser aplicadas em caso de esgotamento dos primeiros sem sucesso, conforme já foi detidamente analisado no Capítulo 2, itens 2.3.1 e 2.3.2 supra.

\footnotetext{
${ }^{269}$ WAMBIER. Teresa Alvim. Reflexões sobre o ônus da prova. Revista de Processo. Sao Paulo, v. 19, n. 76, p.141-145, out./dez. 1994.

${ }^{270}$ DINAMARCO, Cândido Rangel. Instituições de direito processual civil, cit., 6. ed., v. 3, p. 54-55.
} 
Há que se relembrar, também, que os poderes-instrutórios do juiz, tal como os demais poderes-deveres por ele exercidos no processo, não são ilimitados, nem induzem a um poder discricionário ${ }^{271}$, pois, nas palavras de Bandeira de Mello $^{272}$ : “As decisões jurisdicionais, quaisquer que sejam, confirmadas ou reformadas, persistentes ou superadas por orientação jurisprudencial nova, são sempre proferidas na qualidade de atos vinculados a dizer o Direito."

Também nesse sentido se posiciona Amendoeira Jr., ao analisar os limites aos poderes-deveres instrutórios do juiz:

"O mesmo deve ser dito em relação aos poderes instrutórios do juiz, ou seja, tanto a apreciação com a conveniência na produção da prova, quando no ato de requerer a produção de prova ex officio, quando no momento de avaliar as provas já produzidas, vigora o princípio do livre convencimento do juiz, mas esse livre convencimento deve ser motivado, o que lhe retira seu caráter discricionário e certamente permite sua revisão e controle pela via recursal.",273

A conduta judicial, nesses termos, deve se ater aos parâmetros acima expostos e atentar a alguns limites, como a garantia da razoável duração do processo, a adstrição aos limites objetivos da demanda e aos elementos constantes nos autos e à necessidade, utilidade e possibilidade da prova.

Assim, em que pese os deveres-poderes instrutórios do juiz, o processo não pode se prolongar indefinidamente, porque as exigências voltadas à pacificação social estabelecem limites para a atividade probatória.

\footnotetext{
${ }^{271}$ Sobre a inexistência da chamada "discricionariedade judicial”, Teresa Arruda Alvim Wambier observa: " $A$ diferença fundamental que há entre o preenchimento (em concreto) de um conceito vago - fenômeno a que, como se disse, muitos designam, com alguma impropriedade de 'discricionariedade' judicial - e a discricionariedade propriamente dita, é que quando uma norma encampa um conceito vago, em sua redação, ela é concebida com o escopo de gerar uma só interpretação, ou seja, a gerar uma situação tal, de molde a que dela se extraia uma só interpretação, um só resultado (...) Com isso,tem-se que o juiz nunca tem diante de si vários caminhos dentre os quais pode, indiferentemente, escolher um, sendo, todos, juridicamente lícitos e 'queridos' pela norma, embora uns possam ser 'melhores' que outros. Para o magistrado há uma solução, que há de ser tida como a correta: a desejada pelo legislador e 'determinada' pela norma, ainda que o caminho para que se chegue até ela não seja dos mais fáceis." (in, Existe a 'discricionariedade' judicial? Revista de Processo. Sao Paulo, v. 18, n. 70, p. 232-234, abr./jun. 1993). Nesse mesmo sentido, confira-se: GRAU, Eros Roberto. A ordem econômica na Constituição de 1988. 7. ed. São Paulo: Malheiros, 2002; BARBOSA MOREIRA, José Carlos. Regras de experiência e conceitos jurídicos indeterminados. In: Temas de Direito Processual Civil: segunda série. São Paulo: Saraiva, 1988 e TALAMINI, Eduardo. Tutela relativa aos deveres de fazer e de não fazer. São Paulo: Ed. Revista dos Tribunais, 2001.

${ }^{272}$ BANDEIRA DE MELLO, Celso Antônio. Discricionariedade e controle jurisdicional. 2. ed. São Paulo: Malheiros Ed., 1998.

${ }^{273}$ AMENDOEIRA JUNIOR, Sidnei. Poderes do juiz e tutela jurisdicional: a utilização racional dos poderes do juiz como forma de obtenção da tutela jurisdicional efetiva, justa e tempestiva, cit., p. 87.
} 
Com efeito, uma eventual extensão demasiada ao princípio dos poderes-deveres instrutórios do juiz pode levar a um prolongamento do processo incompatível com a garantia da razoável duração, a ponto de ofender também o princípio do tratamento isonômico das partes, não pela iniciativa probatória do juiz, mas pelo não encerramento do litígio em lapso temporal razoável ${ }^{274}$.

Ademais, não se pode, sob o manto da defesa dos poderes-instrutórios do juiz, aceitar o extrapolamento dos limites objetivos da lide, avançando sobre matéria ou pedido jamais deduzido pelas partes. Também não se concebe transformar o juiz em agente de investigação, "cavando provas" e colhendo dados não constantes dos autos. O que se afirma, portanto, é a atividade instrutória do juiz deve se guiar por informações já contidas nos autos. Conforme exemplo colhido na doutrina, o juiz pode determinar ex officio a inquirição de testemunha referenciada pela parte, mas não pode agir como investigador particular dos fatos, de forma a desvendar novas fontes de prova.

A possibilidade do exercício dos poderes instrutórios pelo juiz também exige, tal como à parte, que a prova a ser produzida seja cumulativamente: necessária, útil e possível $^{275}$, versando sobre fatos controvertidos, relevantes e determinados, como já tratado no Capítulo 2, item 2.1 supra.

Verifica-se, ainda, um limite à iniciativa probatória oficial imposto pela técnica processual, consistente na aplicação dos efeitos da revelia, com a consequente presunção de veracidade dos fatos narrados (art. 319 e 334, III, CPC). Em casos tais, como ensina Bedaque $^{276}$, o próprio ordenamento processual já optou claramente pelo valor efetividade, em detrimento da segurança jurídica, não sendo lícito ao juiz a determinação, nesses casos, de abertura da instrução processual, exceção feita à hipótese, largamente aceita em âmbito doutrinário e jurisprudencial, de o juiz reputar inverossímil os fatos narrados, já que seria inconcebível obrigar o juiz a julgar contra sua consciência.

Finalmente, há que se registrar que todo aumento de poder acarreta o correlato aumento de responsabilidade, ao qual, evidentemente, não está imune o juiz, que pode ser

\footnotetext{
${ }^{274}$ Cf. FERREIRA, William dos Santos. Princípios fundamentais da prova cível, cit., p. 212.

${ }^{275}$ Cf. FERREIRA, William dos Santos. Princípios fundamentais da prova cível, cit., p. 212-213.

${ }^{276}$ BEDAQUE, José Roberto dos Santos. Poderes instrutórios do juiz, cit., p. 156.
} 
responsabilizado por falta ou excesso no exercício dos poderes que a lei processual the atribui $^{277}$, matéria que será abordada de forma mais específica no Capítulo 6 infra.

\subsubsection{Partes: a abrangência do princípio do contraditório}

Por outro lado, o fortalecimento dos poderes instrutórios do juiz, no ensejo de um processo civil de viés publicista e colaborativo, é contrabalanceado pelo fortalecimento dos poderes das partes, que devem ter posição mais ativa e leal tanto na atividade probatória, como no debate de matérias de fato ou de direito, ou seja, em todo o processo de formação da decisão judicial.

E essa estrutura participativa do processo, também como já dito, não decorre apenas e tão-somente de uma visão axiológica do fenômeno processual, mas sim encontra raízes constitucionais. Com efeito, o contraditório efetivo constitui exigência da própria democracia participativa. Ele é a expressão jurídica de um elemento político, inerente ao Estado de Direito, que é a garantia da participação.

O contraditório, como é sabido, constitui elemento essencial do fenômeno processual, dada a natureza dialética do processo, que pressupõe a participação dos interessados em todo o iter procedimental e, especialmente, na formação do convencimento do órgão judicial, eis que a decisão a ser prolatada que irá atingir irremediavelmente suas esferas jurídicas. Tanto é assim que Liebman, ao conceituar os sujeitos da relação processual, define como partes "os sujeitos do contraditório instituído perante o juiz" ${ }^{278}$.Nas palavras de Calamandrei:

\footnotetext{
"no processo, o juiz não está só. O processo não é um monólogo: é um diálogo, uma conversação, uma troca de propostas, de respostas, de réplicas; um intercâmbio de ações e reações, de estímulos e de impulsos contrários, de ataques e contra-ataques. Por isso, foi comparado a uma luta ou disputa esportiva; mas cuida-se de uma luta de persuasões e uma disputa argumentativa." 279
}

\footnotetext{
${ }^{277}$ BARBOSA MOREIRA, José Carlos. Os novos rumos do processo civil brasileiro. Revista de Processo, Sao Paulo, v. 20, n. 78, p. 140, abr./jun. 1995.

${ }^{278}$ LIEBMAN, Enrico Tullio. Manual de direito processual civil, cit., v. 1, p. 123.

${ }^{279}$ CALAMANDREI, Piero. Eles, os juízes, vistos por um advogado, cit, p. 145
} 
Yarshell, em obra já diversas vezes citada neste estudo ${ }^{280}$, defende que o contraditório, especialmente no que se refere à participação na produção das provas, destina-se não apenas à formação da decisão judicial, mas também se dirige às próprias partes, como meio de formar sua convicção e determinar a adoção de certos comportamentos, tais como o ingresso em juízo, a autocomposição, etc. Nesse sentido, o contraditório deixa de ser apenas fator de legitimação da decisão judicial e passa a ser elemento determinante da conduta responsável das partes.

Ademais, ainda que caiba ao juiz a direção formal do processo, e se reconheça a amplitude de seus poderes instrutórios (respeitados os limites já analisados), o juiz deve fazê-lo de maneira dialogal, colhendo a impressão das partes a respeito dos rumos a serem tomados no processo, possibilitando que elas dele participem, influenciando a respeito de suas possíveis decisões. Até mesmo porque o direito à prova, para ser efetivo, não pode se limitar à sua produção, abarcando também o direito de vê-la considerada e valorada pelo juiz.

A esse respeito, importante a lição de Oliveira:

\begin{abstract}
"Ora, a idéia de cooperação, além de exigir, sim, um juiz ativo e leal, colocado no centro da controvérsia, importará senão o restabelecimento do caráter isonômico do processo pelo menos a busca de um ponto de equilíbrio. Esse objetivo impõe-se alcançado pelo fortalecimento dos poderes das partes, por sua participação mais ativa e leal no processo de formação da decisão, em consonância com uma visão não autoritária do papel do juiz e mais contemporânea quanto à divisão de trabalho entre o órgão judicial e as partes". ${ }^{281}$
\end{abstract}

Em suma, o processo civil atual não se contenta com o contraditório meramente formal, devendo se ter presente que "na perspectiva judicial a sentença é resultado do trabalho conjunto de todos os sujeitos do processo" 282 .

Além disso, notadamente no que se refere à instrução probatória, são as partes - e não o juiz - quem tem acesso à fonte da prova e que são os maiores interessados no êxito de suas proposições. Nesse sentido, nem mesmo o juiz mais comprometido com a causa

\footnotetext{
${ }^{280}$ YARSHELL, Flávio Luiz. Antecipação da prova sem o requisito da urgência e direito autônomo à prova, cit., p. 168 e seg.

${ }^{281}$ OLIVEIRA, Carlos Alberto Alvaro de. Do formalismo-valorativo no confronto com o formalismo excessivo, cit., p. 158.

${ }^{282}$ OLIVEIRA, Carlos Alberto Alvaro de. Poderes do juiz e visão cooperativa do processo. Revista da Ajuris, Porto Alegre, v. 30, n. 90, p. 74, jun. 2003.
} 
terá condições de, sozinho, suprir a inércia da parte com relação à formação da prova necessária ao reconhecimento do direito.

$\mathrm{O}$ ativismo judicial em matéria de prova, portanto, deve ser conciliado com o ativismo das partes, valorizando-se o diálogo judicial, que se verifica pela cooperação do juiz com as partes e destas com aquele, de acordo com as regras de processo. Em outras palavras, o ativismo judicial não pode - nem deve - substituir a participação atuante das partes no esclarecimento dos fatos.

A idéia de contraditório, nessa nova concepção, traz consequências importantes tanto na investigação dos fatos como na prolação da decisão.

Ora, não há dúvida que a delimitação do thema decidendum, ou seja, a fixação do pedido e causa de pedir, cabe com exclusividade às partes, o que se dá na fase postulatória. Independentemente da natureza do direito discutido, a faculdade de iniciar e delimitar a demanda - salvo raríssimas exceções - é exclusiva das partes. Todavia, no que concerne à investigação dos fatos deduzidos, reconhece-se os amplos poderes instrutórios juiz, diretamente relacionados ao princípio da persuasão racional e à proibição do non liquet, os quais são controlados, por sua vez, pela participação direta das partes na colheita e produção das provas, pelo dever de motivação das decisões judiciais e possibilidade de reexame das decisões judiciais.

Por outro lado, no que se refere à prolação da decisão, a atual concepção do contraditório impõe o reconhecimento da importância da participação das partes não apenas na formação do conjunto probatório, mas também na apreciação do direito, o que importa uma nova visão do princípio jura novit curia $^{283}$, de forma a assegurar que não serão surpreendidas com o rumo tomado pelo processo, o que será retomado no item 5.1.1 infra.

E essa concepção, frise-se, constitui expressão autêntica da garantia de democratização do processo, totalmente compatível, portanto, com os preceitos inerentes ao Estado Democrático de Direito brasileiro.

\footnotetext{
${ }^{283}$ CF. OLIVEIRA, Carlos Alberto Alvaro de. O juiz e o princípio do contraditório. Revista de Processo, São Paulo, v. 19, n. 73, p. 7-14, jan./mar. 1994.
} 


\section{MANIFESTAÇÕES DO DEVER DE COLABORAÇÃO NA INSTRUÇÃO PROCESSUAL}

O reconhecimento da existência de um dever de colaboração das partes e do juiz para a elucidação dos fatos controvertidos traz como consequência a exigência de determinadas condutas, determinados comportamentos desses sujeitos na instrução probatória.

Nesse sentido, longe da pretensão de uma enumeração exaustiva, passaremos a analisar alguns exemplos colhidos na doutrina, na jurisprudência e nas próprias regras processuais, dessas condutas exigíveis das partes e do juiz no curso da instrução processual.

\subsection{Quanto ao juiz}

A colaboração do juiz na instrução processual guarda estreita relação com o exercício dos poderes instrutórios e com a exigência de um comportamento ativo e participativo do juiz na instrução processual, matéria já tratada nos Capítulo 2, item 2.3.2 e Capítulo 4, item 4.1.1 supra.

Como já se assentou anteriormente, no processo civil de viés publicista e cooperativo, a iniciativa probatória do juiz deve anteceder o eventual julgamento do litígio pelas regras de distribuição do ônus da prova, entendido este como caminho subsidiário, a ser utilizado apenas diante da insuficiência do quadro probatório após os esforços probatórios das partes e também do juiz, consideradas as peculiaridades e os limites anteriormente tratados quanto aos poderes instrutórios do juiz.

Mas a colaboração do órgão jurisdicional não deve se limitar à iniciativa probatória oficial, como se passará a demonstrar a seguir. 


\subsubsection{Deveres de esclarecimento, prevenção, consulta e auxílio}

A direção "dialogal" do processo impõe que o juiz, agindo ativamente, construa o resultado do processo em coordenação com as partes interessadas - essencialmente o autor e réu, mas incluindo também eventuais intervenientes, litisconsortes e Ministério Público possibilitando que possam participar dos rumos do processo e influenciar, de maneira efetiva, sobre as possíveis decisões.

Justamente nesse sentido, a doutrina identifica na figura do juiz os deveres de esclarecimento, prevenção, consulta e auxílio para com os litigantes ${ }^{284}$.

O dever de esclarecimento consiste no dever de esclarecer junto às partes qualquer dúvida que surja quanto às alegações, pedidos ou posições exercidas em juízo. Assim, afastando-se de uma postura neutra, formalista e absolutamente fria e indiferente ao resultado do litígio, deve o juiz esclarecer junto às partes qualquer dúvida surgida sobre a pretensão deduzida, sobre determinada alegação fática, sobre a finalidade de determinada prova requerida, sobre a necessidade de oitiva de testemunha localizada fora da Comarca ou do país, sobre a viabilidade de a parte trazê-la à audiência independentemente de expedição de carta precatória, etc.

Uma postura mais interessada e participativa do juiz também é exigível, especialmente, na condução das audiências de instrução, nas quais muitas vezes, pelo que se assiste no cotidiano forense, o ambiente austero, o excesso de formalismo e o uso de jargões forenses e linguagem rebuscada, absolutamente desconhecidas fora do "ambiente jurídico", atuam como fatores de intimidação das partes e das testemunhas, especialmente as mais humildes, que acabam, muitas vezes, deixando de contribuir como poderiam para o esclarecimento dos fatos e, consequentemente, para o alcance dos objetivos da jurisdição.

Mauro Cappelletti e Bryant Garth, ao tratarem das questões que dificultam o acesso à justiça, mencionam que:

"procedimentos complicados, formalismo, ambientes que intimidam, como o dos tribunais, juízes e advogados, figuras tidas como opressoras,

\footnotetext{
${ }^{284}$ Cf. MITIDIERO, Daniel. Colaboração no processo civil: pressupostos sociais, lógicos e éticos, cit., p. 76, SOUSA, Miguel Teixeira de. Estudos sobre o novo processo civil. 2. ed. Lisboa: Lex, 1997. p. 65-67 e COSTA E SILVA, Paula. Acto e processo. Coimbra: Ed., 2003. p. 591.
} 
fazem com que o litigante se sinta perdido, um prisioneiro num mundo estranho." 285

Puoli, em apoio ao incremento do diálogo e da proximidade entre juiz e partes, também faz críticas ao excesso de formalismo na postura pessoal e o rebuscamento da linguagem dos juízes. E, consignando que esses fatores nada contribuem para o respeito à Justiça, aos seus magistrados e às suas decisões, assim explica:

“(...) parece certo que muito maior consideração e respeito dos jurisdicionados merecerá o juiz que, independentemente do uso da beca ou de sua autoridade, estiver procedendo com respeito e isenção em face das partes e de suas alegações, ouvindo o dialogando com elas para, a final, conceder uma tutela amparada em critérios de justiça e que tenha eficácia material para, num tempo adequado, produzir os resultados similares aos que teriam sido verificados na hipótese de o direito material ter sido espontaneamente observado., 286

O dever de prevenção, por sua vez, consiste no dever de prevenir às partes de o êxito restar prejudicado diante do perigo do uso inadequado do processo.

A prevenção, pelo que compreendemos, está relacionada de forma mais intensa com a necessidade de oportunizar às partes a correção de eventuais vícios que impeçam o processo de seguir seu rumo natural em direção à solução de mérito, como é exemplo clássico a abertura de prazo para aditamento da petição inicial (art. 284, CPC). A interpretação do dispositivo legal em consonância com o dever de prevenção nos leva à conclusão de que não basta ao juiz apenas oportunizar a manifestação do autor. Cabe-lhe, mais do que isso, apontar efetivamente os "defeitos ou irregularidades capazes de dificultar o julgamento do mérito", de molde a propiciar sua correção pela parte.

E nem se diga que essa solução comprometeria a imparcialidade do juiz, pois a efetiva solução do "defeito" ou "irregularidade" cabe com exclusividade à parte, devendo o juiz apenas identificar o defeito e a explicitar a razão pela qual sua manutenção levará à extinção prematura do processo.

Justamente nesse sentido, como exemplo do dever de prevenção, Gonzalez Peres, com apoio na jurisprudência do Tribunal Constitucional espanhol, observa que é vedado ao juiz não conhecer de determinada postulação da parte por defeito processual sanável sem

\footnotetext{
${ }^{285}$ CAPPELlETTI, Mauro; GARTH, Bryant. Acesso à justiça. Trad. e Rev. Ellen Gracie Northfleet. Porto Alegre: Sergio Antonio Fabris Editor, 2002. p. 24.

${ }^{286}$ PUOLI, José Carlos Baptista. Os poderes do juiz e as reformas do processo civil, cit., p. 52.
} 
que tenha dado oportunidade para a parte saná-lo, o que afronta o direito à tutela jurisdicional efetiva ${ }^{287}$.

A prevenção também pode ser relacionada ao abuso das posições jurídicas processuais, tema tratado no Capítulo 3 supra, devendo o juiz, como lá dito, sempre que possível, alertar a parte para as consequências de sua conduta processual inadequada, até mesmo como forma de desencorajá-la e coibir o resultado prejudicial à contraparte e mesmo ao Estado.

O dever de consulta, por sua vez, diz respeito ao dever de consultar as partes antes de decidir qualquer questão, permitindo que elas influenciem o convencimento judicial.

Como é sabido, determinadas matérias, dada sua relevância para o ordenamento jurídico e também para o regular desenvolvimento do processo (como são exemplo as nulidades absolutas, a competência absoluta, as condições da ação, os pressupostos processuais, etc.), denominadas "matérias de ordem pública", são cognoscíveis de ofício pelo juiz, indepententemente de alegação de qualquer das partes.

Sob o viés cooperativo, no entanto, o permanente diálogo judicial entre juiz e partes exige que até mesmo essas questões, uma vez identificadas pelo juiz no processo, sejam previamente submetidas à manifestação das partes, evitando que estas sejam pegas de surpresa, por exemplo, com o encerramento abrupto do processo por questão processual de que não tiveram a oportunidade de se pronunciar.

Hipótese típica diversas vezes citada pela doutrina consiste no reconhecimento da prescrição. Ainda que o CPC possibilite atualmente a extinção do processo de ofício pelo juiz nesses casos (art. 219, § 5º ), CC prevê diversas hipóteses de impedimento, suspensão e interrupção da prescrição, além da possibilidade de renúncia pelo devedor (art. 191 e seguintes). Sendo assim, entende-se mais adequado que o juiz, ao invés de decretar liminarmente a prescrição, proceda, antes disso, a oitiva do autor sobre a matéria, de molde a evitar que seja prolongado indevidamente o trâmite processual, com a natural interposição de recurso dessa decisão.

\footnotetext{
${ }^{287}$ PEREZ, Jesús Gonzales, El derecho a tutela jurisdicional. 2 ed., Madris: Civitas, 1989, p. 65-66, apud MITIDIERO, Daniel. Colaboração no processo civil: pressupostos sociais, lógicos e éticos, cit., p. 76.
} 
Além disso, a atual concepção do contraditório impõe o reconhecimento da importância da participação das partes também na apreciação do direito, o que importa uma nova visão sobre o alcance do antigo brocardo jura novit curia.

Como ensina Oliveira ${ }^{288}$, embora inexista obrigação formal, tampouco constitua ônus da parte, existe um "interesse primordial" em dar conhecimento ao juiz da norma ou da solução jurídica que, segundo seu entendimento, deve ser aplicada ao caso. Até mesmo porque sempre poderá haver o risco de o juiz não aplicar determinada norma jurídica favorável ao litigante ou de não interpretá-la corretamente.

Aliás, ainda segundo o citado professor, o próprio ordenamento processual brasileiro confirma a relevância da colaboração das partes e seu legítimo interesse em aportar subsídios não apenas para o esclarecimento dos fatos, mas também para a valoração jurídica da causa.

Nesse sentido, a intervenção do revel no processo "em qualquer fase, recebendo-o no estado em que se encontrar" (art. 322, parágrafo único, CPC) é possibilitada, justamente, porque a presunção de veracidade, decorrente da revelia, é aplicável apenas à matéria fática, nada impedindo o revel de se manifestar e de persuadir o julgador com argumentos jurídicos. Além disso, os artigos 300 e 454, § $3^{\circ}, \mathrm{CPC}$, ao se referirem, respectivamente, à contestação e às alegações finais, fazem referência expressa à possibilidade de as partes se manifestarem relativamente tanto às questões de fato como às de direito, sendo certo que ambos os aspectos decorrem da exigência do contraditório. $\mathrm{E}$, nas palavras conclusivas de Oliveira:

\footnotetext{
"a problemática ora abordada não está ligada apenas ao interesse das partes, mas encontra íntima conexão com o próprio interesse público, na medida em que qualquer surpresa, qualquer acontecimento inesperado, só faz diminuir a fé do cidadão na administração da Justiça. O diálogo judicial torna-se, no fundo, dentro dessa perspectiva, autêntica garantia de democratização do processo, a impedir que o poder oficial do órgão judicial e a aplicação da regra iura novit cúria venham a se transformar em instrumento de opressão e autoritarismo, servindo às vezes a um mal explicado tecnicismo, com obstrução à efetiva e correta aplicação do Direito." ${ }^{289}$.
}

\footnotetext{
${ }^{288}$ OLIVEIRA, Carlos Alberto Alvaro de. O juiz e o princípio do contraditório, cit., p. 37.

${ }^{289}$ OLIVEIRA, Carlos Alberto Alvaro de. O juiz e o princípio do contraditório, cit., p. 37.
} 
O dever de auxílio, por seu turno, corresponde ao dever de auxiliar as partes na superação de eventuais dificuldades que impeçam o exercício de direitos ou faculdades ou, então, o cumprimento de deveres e ônus processuais.

O dever de auxílio, evidentemente, não impõe e nem autoriza ao juiz que se substitua às partes, ou seus procuradores, nas atividades inerentes e essenciais à defesa dos seus direitos, como a dedução de exceções materiais, pesquisa das fontes de prova, etc.

Esse dever se impõe, no entanto, nas hipóteses em que o acesso à determinada prova ou informação é obstaculizado à parte, seja em razão da negativa de terceiro em fornecê-la (o que autoriza, em certos casos, até mesmo a ordem de busca e apreensão), seja em razão caráter sigiloso do documento ou da informação (o que autoriza a requisição de informações às repartições públicas, nos termos do art. 399, CPC). Exemplo clássico é a requisição de informações à Receita Federal a respeito da existência de bens em nome do devedor, para efeito de penhora em processo de execução.

Puoli, ao tratar da necessidade de uma maior proximidade entre juiz e partes no processo (ou seja, do incremento do diálogo judicial ou, nas suas palavras, do "diálogo cooperativo" ${ }^{, 290}$ ) sustenta que esse tipo de atividade não prejudica a imparcialidade judicial, porque "a imparcialidade está ligada à vedação de favorecimento de uma das partes e não à provocação e troca de informações (entre o Juiz e as partes) que possa redundar numa melhora da prestação jurisdicional ${ }^{, 291}$.

\subsubsection{Fixação dos pontos controvertidos}

Finalizada a fase postulatória, com o regular exercício do direito de ação e de defesa, e realizadas as providências preliminares, segue-se então a fase "saneadora", na qual incumbe ao juiz organizar o processo de maneira retrospectiva e prospectiva.

Sob o aspecto retrospectivo, deve o juiz, após adotar as providências preliminares, sanar, sempre que possível, eventuais vícios dos atos processuais que possam obstaculizar o regular andamento do processo rumo ao julgamento de mérito. Já sob o aspecto

\footnotetext{
${ }^{290} \mathrm{O}$ autor prefere a expressão "diálogo cooperativo" ao uso simplesmente dos termos "cooperação" ou "colaboração", por entender que estes termos, em linguagem coloquial, trazem a ideia de ajuda, o que poderia fazer pensar que o juiz poderia estar ajudando uma das partes, o que difere do sentido técnico que aqui se pretende utilizar.

${ }^{291}$ PUOLI, José Carlos Baptista. Os poderes do juiz e as reformas do processo civil, cit., p. 50-51.
} 
prospectivo, não sendo o caso de extinção do processo ou de julgamento antecipado da lide, deve o juiz então fixar o thema probandum e delimitar as provas que serão produzidas.

Neste ponto reside, pois, um relevantíssimo dever atribuído ao juiz mas, infelizmente, muitas vezes deixado de lado no cotidiano forense, como se fora mera formalidade inútil e irrelevante para os fins perseguidos pelo processo: a fixação dos pontos controvertidos ${ }^{292}$.

O juiz, instando as partes a colaborar, deve delimitar, previamente, o tema da prova, ou melhor, as alegações de fato deduzidas pelas partes que devem ser objeto de prova, relembrando-se, neste ponto, o que já se falou sobre o objeto da prova no Capítulo 2, item 2.1, ou seja, devem ser provadas, em princípio, as alegações controversas, pertinentes e relevantes, ressalvando-se as situações excepcionais lá tratadas.

A delimitação do objeto da prova atende plenamente aos postulados da economia processual e da efetividade, evitando a perda de tempo e de energia futuras pelas partes e pelo juiz, com requerimentos impertinentes ou até mesmo tumultuários do feito, além de ser de fundamental também para a avaliação do comportamento da parte na fase instrutória, em especial para a verificação de eventuais condutas procrastinatórias. Nas palavras de Komatsu:

“A fixação dos pontos controvertidos é de insubstituível cumprimento
pelo juiz. De tal forma, se sustenta que antes de ordenar a abertura do
período probatório, o juiz deve fixar com clareza quais são os fatos
controvertidos, a fim de que sobre eles, e só sobre eles, as partes
ofereçam os meios adequados que acreditem suas respectivas afirmações
vertidas nos escritos constitutivos do processo." ${ }^{293}$

Evidentemente, a fixação dos pontos controvertidos exige do juiz uma análise mais atenta e aprofundada das alegações das partes e do objeto litigioso já nessa fase procedimental, o que certamente lhe tomará certo tempo. No entanto, um processo bem saneado, com as questões controvertidas adequadamente analisadas e delimitadas (e que servirão de baliza para o deferimento ou rejeição das provas cuja produção foi requerida pelas partes), permitirá uma fase probatória mais eficiente e, certamente, auxiliará o juiz quando da prolação da sentença.

\footnotetext{
${ }^{292}$ Ver a respeito: RIBEIRO, Darci Guimarães. Provas atípicas. Porto Alegre: Livr. do Advogado, 1998. p. 57 e MITIDIERO, Daniel. Colaboração no processo civil: pressupostos sociais, lógicos e éticos, cit., p. 123 e ss.

${ }^{293}$ KOMATSU, Roque. Notas em torno dos deveres processuais dos juízes, cit, p. 718.
} 
Há de se frisar, ainda, que a audiência preliminar prevista no artigo 331, CPC, constitui o momento por excelência para a fixação dos pontos controvertidos, como dispõe a própria norma processual (artigo 331, $\$ 2^{\circ}, \mathrm{CPC}$ ), com a vantagem de que o debate assim realizado, na presença do juiz, das partes e de seus advogados, potencializa em muito o resultado útil, com uma melhor compreensão sobre o objeto litigioso e sobre as provas pertinentes à comprovação das alegações das partes ${ }^{294}$.

Há mais: a fixação do objeto da prova em audiência, além de prestigiar o princípio da oralidade, tende a minimizar as chances de serem determinadas provas já sabidamente inservíveis para o fim pretendido e que tenham, portanto, intuito meramente protelatório. $\mathrm{E}$ isto se dá para uma razão psicológica e comprovável no dia-a-dia forense, qual seja, a maior dificuldade que encontram os advogados de criar e expor oralmente - e de improviso - justificativas sabidamente falsas para convencer o juiz da necessidade de produzir determinada prova.

Seja como for, ainda que, por razão justificável, não seja designada a audiência preliminar do art. 331, CPC, o juiz não pode se furtar à fixação dos pontos controvertidos, ou seja, a deliminar o objeto da prova, o que, nesse caso, deverá ser feito no momento da decisão de saneamento do processo.

\subsubsection{Distribuição do encargo probatório - momento de inversão do ônus da prova}

A questão do ônus da prova, já tratada no Capítulo 2, item 2.3.1 supra, está diretamente relacionada às consequências da eventual lacuna probatória verificada no processo. Assim, por meio de regras preestabelecidas, a lei processual determina qual das partes arcará com as consequências da insuficiência probatória caso o julgamento tenha que ser realizado com base na regra de distribuição do ônus da prova.

Em regra, cabe ao autor produzir prova dos fatos constitutivos de seu direito e ao réu, por sua vez, compete provar os fatos modificativos, extintivos ou impeditivos do direito do autor, quando alegados (art. 333, CPC).

Há casos, no entanto, em que essa regra de distribuição do ônus da prova é invertida pela própria disposição da lei (inversão legal), tal como ocorre na hipótese do

\footnotetext{
${ }^{294}$ Daniel Mitidiero, nesse sentido, refere-se a uma "comunhão cooperativa para a seleção do objeto da prova". MITIDIERO, Daniel. Colaboração no processo civil: pressupostos sociais, lógicos e éticos, cit., p. 124.
} 
artigo 38 do CDC (Lei 8.078/90), que impõe ao fornecedor-anunciante o ônus da prova da veracidade e correção da informação publicitária veiculada. Também é possível às partes, convencionalmente, atribuirem-se de modo diverso o ônus probatório (inversão convencional), desde que o litígio não verse sobre direitos indisponíveis, nem a inversão torne excessivamente difícil o exercício da pretensão (art. 333, parágrafo único, CPC).

Em todos esses casos, o litigante já tem conhecimento, desde o início do litígio, do ônus que lhe recai, tendo plenas condições de guiar sua conduta processual de acordo com essa diretriz. O mesmo não acontece, no entanto, na hipótese de inversão judicial do ônus da prova, tal como previsto no artigo $6^{\circ}$, VIII, do CDC (Lei 8.078/90).

Com efeito, a Lei 8.078/90, com a finalidade de equilibrar as relações de consumo e facilitar a defesa do consumidor em juízo, dada sua reconhecida vulnerabilidade, prevê a possibilidade de o juiz determinar, no caso concreto, a inversão do ônus probatório no processo civil, quando verificar: a verossimilhança da alegação e a hipossuficiência do consumidor "segundo as regras ordinárias da experiência" 295.

A inversão do ônus probatório, nesse caso, não decorre automaticamente da lei, mas, contrariamente, depende de decisão judicial que, por sua vez, deverá ser fundamentada na presença dos requisitos legais autorizadores dessa inversão.

Nesse sentido, entendemos que as partes não podem ser surpreendidas com a inversão do ônus da prova no momento do julgamento, devendo, ao contrário, ser previamente intimadas dessa decisão, e em momento processual que lhes possibilite a produção de provas de suas alegações.

Essa exigência, por sua vez, constitui manifestação do dever de colaboração do juiz na instrução e do viés cooperativo do processo civil atual, que se pauta pela construção do resultado do processo em coordenação com as partes interessadas e sem surpresas indevidas aos litigantes.

A doutrina contrária, que admite a inversão do ônus probatório no momento do julgamento, representada por respeitáveis juristas e acompanhada por expressivos precedentes judiciais, sustenta que essa autorização decorre da própria natureza jurídica das regras de distribuição do ônus da prova. Assim, por se tratar de regra de julgamento, seria aplicável apenas quando esgotadas sem êxito as atividades probatórias, não devendo

\footnotetext{
${ }^{295}$ Debate-se a doutrina a respeito da exigência concomitante ou alternativa desses requisitos legais, matéria que, no entanto, extrapolaria os limites do presente estudo, razão pela qual optamos por não abordá-la.
} 
ser cogitada anteriormente a esse momento. Nesse sentido se posicionam os próprios autores do anteprojeto da Lei 8.078/90, representados por Filomeno ${ }^{296}$, assim como Batista Lopes $^{297}$, Nery Junior e Andrade Nery ${ }^{298}$, Fidélis dos Santos ${ }^{299}$, Pacífico ${ }^{300}$, dentre outros.

Mattos $^{301}$, nessa mesma linha de entendimento, defende ainda que não há cerceamento de defesa no caso, nem o fornecedor pode alegar surpresa, já que a possibilidade hipotética de inversão do ônus probatório é prevista em lei, não podendo o litigante alegar desconhecimento. Pelo contrário: ciente dessa possibilidade, deve se empenhar em produzir todas as provas possíveis, sob pena de correr o risco de vir a ser condenado em caso de inversão do ônus.

Dinamarco, ao tratar do tema, apesar de entender que a inversão do ônus, enquanto regra de julgamento, ocorre apenas no momento da sentença, ressalta a importância de o juiz informar as partes no momento da audiência preliminar a respeito da possibilidade de inversão do ônus da prova, como decorrência do due process of law e da exigência de diálogo que integra a garantia constitucional do contraditório ${ }^{302}$.

Com a devida vênia, muito embora concordemos inteiramente com as premissas da exigência do diálogo e da transparência das condutas judiciais, acreditamos que essa simples comunicação aos litigantes a respeito da "possibilidade" de inversão do ônus probatório é insuficiente e, na prática, inócua, já que essa possibilidade é decorrente da própria lei, dada a natureza da relação controvertida (relação de consumo).

Parece-nos mais coerente, em função de nosso sistema processual, que a decisão sobre a inversão do ônus da prova ocorra na fase ordenatória do processo preferencialmente ao ensejo da audiência preliminar, ou, não havendo, por ocasião da

${ }^{296}$ GRINOVER, Ada Pellegrini et al. Código Brasileiro de defesa do consumidor: comentado pelos autores do anteprojeto. 9. ed. Rio de Janeiro: Forense Universitária, 2007. p. 149-158.

${ }^{297}$ LOPES, João Batista. A prova no direito processual civil. São Paulo: Ed. Revista dos Tribunais, 2002.

${ }^{298}$ NERY JÚNIOR, Nelson; ANDRADE NERY, Rosa Maria. Código de Processo civil comentado e Legislação processual civil extravagante. 12. ed. São Paulo: Ed. Revista dos Tribunais, 2012. p. 723.

${ }^{299}$ SANTOS, Ernane Fidélis dos. Sistema probatório do processo civil brasileiro. Revista Forense, Rio de Janeiro, v. 97, n. 355, p. 58, maio/jun. 2001.

${ }^{300}$ PACÍFICO, Luiz Eduardo Boaventura. O ônus da prova no direito processual, cit., p. 160.

${ }^{301}$ MATTOS, Cecília. O ônus da prova no Código de Defesa do Consumidor. 1993. Dissertação (Mestrado) Faculdade de Direito, Universidade de São Paulo, São Paulo, 1993. p. 161-169.

${ }^{302}$ Nesse sentido: "A transparência das condutas judiciais é uma inafastável inerência do due process of law e da exigência do diálogo que integra a garantia constitucional do contraditório: o processo civil moderno quer muita explicitude do juiz e de suas intenções, que são fatores indispensáveis à efetividade do justo processo. Por isso, a locução 'determinará as provas a serem produzidas' $\left(\right.$ art. $\left.331, \S 2^{\circ}\right)$ inclui a exigência de esclarecer as partes sobre seus ônus probatórios. Esse mero esclarecimento não deve ser prestado em forma de decisão, vale como advertência e convite a participar da instrução probatória, na medida do interesse de cada uma e com a consciência dos efeitos negativos que poderá suportar em caso de omitir-se." (DINAMARCO, Cândido Rangel. Instituições de direito processual civil, cit., 6. ed., v. 3, p. 82-83). 
decisão saneadora -, devendo o juiz fixar os pontos controvertidos e apreciar a presença dos requisitos legais para a eventual inversão do ônus probatório, com base nas alegações e eventuais elementos probatórios trazidos na fase postulatória, de sorte que as partes iniciem a instrução já cientes de seus respectivos encargos ${ }^{303}$.

Nesse sentido, aliás, é o posicionamento de outros doutrinadores de renome, tais como Theodoro Júnior ${ }^{304}$, Carvalho Filho ${ }^{305}$, Bedaque ${ }^{306}$, Cruz e Tucci ${ }^{307}$, Barbosa Moreira $^{308}$ e Marinoni e Arenhart ${ }^{309}$. A divergência entre eles está apenas quanto momento exato da inversão, defendendo alguns que seria o da fixação dos pontos controvertidos e outros o admitindo até o encerramento da instrução.

O importante, em qualquer caso, como bem defende Cruz e Tucci ${ }^{310}$, é que essa inversão ocorra em momento processual em que ainda seja oportunizada ao réu a chance efetiva de se desincumbir do encargo antes inexistente. ${ }^{311}$. Do contrário, caracterizado estará o cerceamento do direito de defesa do fornecedor.

A tanto confluem diversas e substanciosas razões.

A primeira delas consiste no dever de esclarecimento do juiz, que além de corolário do dever de colaboração aqui defendido, parece decorrer, nessa hipótese, da interpretação do artigo 331, $\S 3^{\circ}$, CPC. Assim, cabe ao juiz, por ocasião da fase ordenatória do processo, atento às exigências de transparência das condutas judiciais e do diálogo, esclarecer a quem caberá o ônus processual em caso de insuficiência da instrução, de modo que a parte

\footnotetext{
${ }^{303}$ Nesse sentido confira-se STJ, Resp 598.620, $3^{\mathrm{a}}$ T., rel. Min. Carlos Alberto Menezes Direito, DJ 18.04.2005 e TJSP, AgIn 121.979-4, 6 a Câmara de Direito Privado, rel. Antonio Carlos Marcato, 07.09.1999.

${ }^{304}$ THEODORO JÚNIOR, Humberto. Direitos do consumidor. 4. ed. Rio de Janeiro: Forense, 2004. p. 148.

${ }^{305}$ CARVALHO FILHO. Milton Paulo de. Ainda a inversão do ônus da prova no código de defesa do consumidor. Revista dos Tribunais, São Paulo, v. 92, n. 807, p. 56-81, jan. 2003.

${ }^{306}$ BEDAQUE, José Roberto dos Santos. Direito e processo, cit., p. 41.

${ }^{307}$ CRUZ E TUCCI, José Rogério; TUCCI, Rogério Lauria. Devido processo legal e tutela jurisdicional. São Paulo: Ed. Revista dos Tribunais, 2003. p. 117.

${ }^{308}$ BARBOSA MOREIRA, José Carlos. Notas sobre a inversão do ônus da prova em benefício do consumidor. Revista de Direito do Consumidor, São Paulo, n. 22, p. 135-149, abr./jun. 1997.

${ }^{309}$ MARINONI, Luiz Guilherme; ARENHART, Sérgio Cruz. Comentários do Código de Processo Civil. São Paulo: Ed. Revista dos Tribunais, 2008. p. 338. Esses professores defendem, inclusive, que a inversão do ônus da prova constitui regra de intrução e não de julgamento.

${ }^{310}$ CRUZ E TUCCI, José Rogério; TUCCI, Rogério Lauria. Devido processo legal e tutela jurisdicional, cit., p. 117.

${ }^{311}$ Teresa Wambier, nessa mesma trilha, entende que a inversão do ônus probatório deve se dar antes da instrução, ou, após encerrada a instrução, quando o juiz somente aí notar a presença dos requisitos legais, hipótese em que deverá converter o julgamento em diligência e reabrir a instrução, de forma a possibilitar ao onerado a produção de provas. WAMBIER, Teresa Arruda Alvim. Noções gerais sobre o processo no Código do Consumidor. Revista de Direito do Consumidor, São Paulo, n. 10, p. 248-257, 1995.
} 
atingida pela inversão possa requerer e produzir as provas que normalmente não requereria, exercendo na plenitude seu direito constitucional de ampla defesa.

Ademais, essa exigência atende ao próprio escopo da jurisdição, já que propicia a realização de um julgamento mais justo e condizente com a realidade dos fatos, aumentando a possibilidade de efetividade da tutela a ser proferida ${ }^{312}$.

Com efeito, se o objetivo da lei, ao prever a possibilidade de inversão do ônus, é impô-lo a quem tem melhores condições de produzir a prova, esse objetivo não será atingido se a inversão se der apenas na sentença, hipótese em que o julgamento, invariavelmente, será calcado em uma ficção. Ou então acarretará a exdrúxula situação que se verifica no cotidiano forense, na qual o fornecedor, inseguro sobre a possibilidade de inversão do ônus da prova, vê-se premido a muitas vezes, por cautela, fazer prova de fatos e responsabilidades absurdas que lhe são imputadas, produzindo provas desnecessárias e atrasando a solução do feito, em prejuízo à economia processual ${ }^{313}$.

Por fim, a possibilidade de inversão apenas no momento do julgamento desconsidera o aspecto subjetivo do ônus da prova ${ }^{314}$, ignorando sua relevante influência sobre o comportamento das partes, ou seja, impossibilitando que direcionem seu comportamento na instrução de acordo com os riscos que lhe recairão em hipótese de insuficiência de provas.

Nesse sentido, essa postura também dificulta a direção material do processo pelas partes, reduzindo, por exemplo, as chances de que o fornecedor, ciente, previamente, da inversão do ônus probatório e da inexistência de provas em seu favor, transacione com o consumidor ainda na fase de conhecimento, ou mesmo opte pelo reconhecimento jurídico do pedido, na tentativa de estancar os custos financeiros da pendência judicial.

Em suma, a nosso ver, o problema da possibilidade de inversão judicial do ônus da prova apresenta-se em dois momentos distintos do processo. No primeiro, por ocasião da ordenação do processo, quando o juiz deverá verificar a presença dos requisitos legais para a inversão e comunicar as partes de sua decisão. No segundo, por ocasião da efetiva

\footnotetext{
${ }^{312}$ Cf. RIBEIRO, Débora de Oliveira. Inversão do ônus da prova no Código de Defesa do Consumidor. 2005. (Dissertação) - Faculdade de Direito, Universidade de São Paulo, São Paulo, 2005. p. 73 e ss.

${ }^{313}$ Cf. SILVA, Bruno Freire e. Inversão Judicial do ônus da prova no CDC. In: CARVALHO, Fabiano; BARIONI, Rodrigo. Aspectos processuais do Código de Defesa do Consumidor. São Paulo: Ed. Revista dos Tribunais, 2008. p. 11-21.

${ }^{314}$ Retomem-se aqui as considerações sobre o aspecto subjetivo do ônus da prova tecidas no Capítulo 2, item 2.3.1.
} 
prolação da decisão, hipótese em que o juiz, não se convencendo dos fatos alegados pelo conjunto probatório produzido, deve julgar desfavoravelmente ao sujeito onerado.

Portanto, muito embora sua efetiva aplicação como regra de julgamento apenas se verifique na fase decisória (quando as provas carreadas aos autos não sejam suficientes para o convencimento judicial), em respeito às garantias do contraditório e da ampla defesa - e também como expressão do dever de colaboração - a inversão do ônus probandi deve ser decidida e informada às partes na fase de ordenação do processo, de sorte a permiti-las direcionem seu comportamento na instrução cientes desse encargo.

\subsubsection{Juízo de admissibilidade da prova e impossibilidade de valoração antecipada de seu resultado}

As alegações fáticas deduzidas pelas partes necessitam, em regra $^{315}$, ser comprovadas através dos meios de prova admitidos em direito (meios lícitos e moralmente legítimos - art. 332, CPC).

O procedimento para tanto é usualmente dividido pela doutrina em quatro etapas (ou quatro momentos da prova): a proposição pela parte, a admissão pelo juiz, a produção ou realização da prova e a sua valoração ${ }^{316}$. Essas etapas, segundo as regras processuais, devem se seguir exatamente nessa sequência cronológica: proposição, admissão, produção e valoração ${ }^{317}$.

Há, no entanto, uma forte tendência nos tribunais brasileiros de, fundando-se no princípio da livre convicção do juiz, indeferir a produção de prova requerida pela parte sob o argumento de "já estar convencido o juiz”.

Trata-se de verdadeira inversão dos planos de admissão e valoração da prova, passando o juiz a pré-julgar o processo em momento impróprio, o que, de acordo com

\footnotetext{
${ }^{315}$ Com exceção das hipóteses já tratadas no Capítulo 2, item 2.1 supra.

${ }^{316}$ Cf. DINAMARCO, Cândido Rangel. Instituições de direito processual civil. 6. ed. São Paulo: Malheiros Ed., 2009. v. 3, p. 88.

${ }^{317}$ Com exceção da prova documental em que, por expressa disposição legal, as etapas de proposição e produção se realizam concomitantemente, já que essas provas, sempre que possível, devem acompanhar a petição inicial e a contestação (art. 396, CPC).
} 
autorizada doutrina, além de ferir o devido processo legal, constitui violação à garantia constitucional da ampla defesa ${ }^{318}$.

Além disso, ao fundamentar o indeferimento da prova na livre convicção, o julgador aplica critérios puramente subjetivos e viola a garantia da fundamentação das decisões.

Esse posicionamento não encontra eco no processo civil em sua concepção atual, que, além de albergar de forma ampla o denominado "direito à prova" e se pautar pelo diálogo e cooperação entre as partes e o juiz, reconhece como destinatários da prova não apenas o juiz, mas também as próprias partes, porque interessadas no seu resultado, e também porque este pode e deve conduzir sua conduta dentro e fora do processo ${ }^{319}$.

Com efeito, sabe-se que o direito (ou o poder) à produção de provas, de índole constitucional, não é ilimitado, assim como não o são todos os demais direitos, que devem conviver em harmonia com outros valores constitucionalmente protegidos, como é o caso das garantias da rápida solução do litígio e da economia processual.

Também é certo, por outro lado, que a admissão ou não das provas requeridas pelas partes não pode ser relegada ao arbítrio judicial, aplicando o julgador critérios vagos e subjetivos, o que impossibilita até mesmo o controle de sua decisão seja pelo jurisdicionado, pela instância superior ou mesmo pela própria sociedade ${ }^{320}$.

Daí a razão pela qual parcela da doutrina processual contemporânea tem voltado sua atenção ao estudo do chamado "juízo de relevância da prova", com o fito de assentar critérios objetivos, lógicos e pretederminados ao exame da admissibilidade da prova, de

\footnotetext{
${ }^{318}$ A respeito do tema consultar: TARUFFO, Michele. Studi sulla rilevanza della prova, cit., p. 77; MITIDIERO, Daniel. Colaboração no processo civil: pressupostos sociais, lógicos e éticos, cit., p. 124, DALL'ALBA, Felipe Camilo. A ampla defesa como proteção dos poderes das partes: proibição de inadmissão da prova por já estar convencido o juiz. In: KNIJNIK, Danilo; CARPES, Artur Thompsen (Coords.). Prova Judiciária: estudos sobre o novo direito probatório, cit., p. 93-104, DEMARI, Lisandra. Juízo de relevância da prova. In: KNIJNIK, Danilo; CARPES, Artur Thompsen (Coords.). Prova Judiciária: estudos sobre o novo direito probatório, cit., p. 171-179.

${ }^{319}$ Recordem-se, nesse aspecto, as considerações já realizadas no Capítulo 2, item 2.1, a respeito dos destinatários da prova.

${ }^{320}$ Carlos Alberto Álvaro de Oliveira, nesse sentido: "O problema é muito mais complexo e mostra-se bem possivel lance mão o órgão judicial, mesmo com uma autêntica proclamação de princípios, ao justificar determinada visão dos fatos, de critérios vagos e indefinidos, empregando fórmulas puramente retóricas despidas de conteúdo, aludindo por exemplo à 'verdade material', 'prova moral', 'certeza moral', 'prudente apreciação', 'intima conviçção' e expressões similares, autênticos sinônimos de arbitrio, subjetivismo e manipulação semântica por não assegurarem nenhuma racionalidade na valoração da prova, implicarem falsa motivação da decisão tomada e impedirem, assim, o controle por parte da sociedade, do jurisdicionado e da instância superior." (OLIVEIRA, Carlos Alberto Alvaro de. Do formalismo no processo civil: proposta de um formalismo-valorativo, cit., p. 219).
} 
modo a evitar a confusão entre a admissibilidade da prova e sua valoração, que deve ser realizada apenas na sentença.

A admissibilidade da prova envolve limitações jurídicas (tais como sua licitude) e também lógicas, o que se traduz no denominado "juízo de relevância”, por meio do qual se verifica, antecipada e hipoteticamente, se as provas pretendidas pelos litigantes são realmente necessárias e úteis ao esclarecimento dos fatos ou se, contrariamente, servirão apenas para atrasar o desfecho do feito (art. 131, CPC) ${ }^{321}$.

Como já se estudou no Capítulo 2, item 2.1 supra, destinam-se à prova os fatos controvertidos, relevantes e determinados, que formam, em seu conjunto, o denominado thema probandum. Nesse sentido, doutrina recente, com fundamento dos ensinamentos de Taruffo, sustenta que o juízo de relevância da produção de determinada prova requerida pela parte deve ser realizado considerando-se, exclusivamente, a relação lógica existente entre o objeto da prova (cada proposição factual específica objeto de prova) e o thema probandum (conjunto de alegações controvertidas nos autos).

Nesse sentido Taruffo ensina que "é relevante cada proposição factual que, assumida por hipótese como verdadeira, pode constituir elemento de confirmação da proposição descritiva do factum probandum, ${ }^{322}$.

O objeto da prova, ademais, pode referir-se tanto a fatos principais (os que possuam, em tese, a eficácia constitutiva, impeditiva, modificativa ou extintiva pretendida por aquele que os alegou) como a fatos secundários (aqueles que, uma vez provados, trazem consequências relativas ao fato principal). O que se exige é que haja nexo objetivo entre o fato a ser provado e os fatos que devem ser acertados em juízo e que o meio probatório seja adequado à sua demonstração, sendo irrelevante a análise da eficácia da prova, o que importa antecipação de sua valoração ${ }^{323}$.

\footnotetext{
${ }^{321}$ Como afirma Felipe Camilo Dall'Alba: "A atividade que o juiz realiza no momento do juízo de relevância e a feita, quando do julgamento, são essencialmente diferentes, pois a primeira, como já foi ressaltado, busca uma relação lógica por hipótese, em tese, já a outra se dá quando da análise final da eficácia da prova." (DALL'ALBA, Felipe Camilo. A ampla defesa como proteção dos poderes das partes: proibição de inadmissão da prova por já estar convencido o juiz, cit., p. 98).

${ }^{322}$ TARUFFO, Michele. Studi sulla rilevanza della prova, cit., p. 249.

${ }^{323}$ Nesse sentido Mitidiero pondera: "Tendo o meio probatório postulado nexo objetivo com o objeto da prova, tem o órgão jurisdicional de admiti-la, sob pena de suforcar-se o caráter democrático que caracteriza o processo civil do Estado Constitucional. Há aí inequivocamente prova necessária à instrução do processo. $\mathrm{O}$ formalismo processual de corte cooperativo leva em conta o ponto de vista de todos aqueles que participam do processo." (MITIDIERO, Daniel. Colaboração no processo civil: pressupostos sociais, lógicos e éticos, cit., p. 32). No mesmo sentido: KNIJNIK, Danilo. A prova nos juízos cível, penal e tributário. Rio de Janeiro: Forense Jurídica, 2007. p. 21.
} 
Utilize-se como exemplo uma ação judicial de natureza reparatória movida por um particular contratado pelo Poder Público para a execução de determinados serviços de engenharia, que teve seu contrato rescindido por justa causa pela administração, por suposto inadimplemento contratual. Na petição inicial, alegando culpa da administração pela rescisão e postulando reparação por perdas e danos, o particular descreve uma série de atos praticados pelo contratante (Poder Público) que inviabilizaram o cumprimento dos prazos contratualmente previstos. Cada um desses fatos descritos, uma vez confirmado, seria suficiente para fundamentar, ao menos em tese, a alegação de culpa do contratante pela rescisão contratual e fundamentar o pedido de reparação de danos. Nesse sentido, deve o juiz possibilitar a realização de prova a respeito de cada uma dessas proposições factuais (objeto de prova), não podendo rejeitá-las sob o argumento de já estar convencido.

Contrariamente, em ação indenizatória fundada em responsabilidade civil objetiva decorrente de relação de consumo, tal como é o caso da responsabilidade de instituição bancária por fraude sofrida por um de seus correntistas, mostra-se indiferente ao resultado do julgamento a eventual contribuição culposa dos prepostos da instituição bancária, bastando a comprovação do dano e do nexo de causalidade ${ }^{324}$. Nesse sentido, por ser irrelevante e não guardar relação lógica com o tema da prova, deve o juiz indeferir a prova oral voltada à demonstração da existência ou inexistência de culpa da instituição.

A questão se complica, no entanto, ainda nesse tema, quando a própria natureza da responsabilidade (objetiva ou subjetiva) é objeto de controvérsia nos autos, seja em razão da divergência quanto à aplicação de um ou outro dispositivo de lei ao caso, seja em razão da existência de divergência jurisprudencial quanto à sua interpretação (pode-se se citar como exemplo a hipótese de responsabilidade objetiva prevista no artigo 927, parágrafo único, do CC, que gerou e gera até os dias atuais dissidentes interpretações). Nessas hipóteses, parece-nos que a inadmissibilidade da prova da culpa poderá ensejar cerceamento do direito de defesa, em especial diante da possibilidade de reexame da questão de direito (natureza da responsabilidade: objetiva ou subjetiva) em grau de recurso.

Seja como for, é necessário estabelecer um ponto de equilíbrio entre o direito à prova e a obtenção de decisões justas, de um lado, e, de outro, as exigências impostas pelos princípios da celeridade, economia e concentração dos atos processuais. Até mesmo

\footnotetext{
${ }^{324}$ A Súmula 479 do Superior Tribunal de Justiça estabelece que: "As instituições financeiras respondem objetivamente pelos danos gerados por fortuito interno relativo a fraudes e delitos praticados por terceiros no âmbito de operações bancárias."
} 
porque o artigo 130 do CPC determina ao juiz que indefira as "diligências inúteis e meramente protelatórias".

Assim, no ensejo da análise do juízo de relevância da prova, Taruffo, apesar de sustentar que o precedente convencimento do juiz não pode ser motivo para a exclusão da prova, propõe que sejam distinguidas duas situações: poderá o juiz indeferir determinado meio de prova quando vise a demonstrar o mesmo fato já comprovado nos autos (por outro meio de prova), e, por outro lado, o juiz não poderá indeferi-lo se tem por finalidade confrontar demonstração fática já existente nos autos ${ }^{325}$.

Relembre-se, ainda, que a própria legislação processual também impõe determinados limites à produção da prova, como é exemplo o artigo 407, parágrafo único, $\mathrm{CPC}$, que autoriza o juiz a dispensar testemunhas quando arroladas pela parte em número superior a três para a prova de cada fato.

Em resumo, entende-se, com apoio em autorizada doutrina, que o juízo de relevância da prova deve se ater à verificação da relação lógica existente, hipoteticamente, entre o objeto da prova e o thema probandum. Não deve o juiz adentrar ao exame de sua eficácia, nem lhe é permitido inadmitir a prova a pretexto de já estar convencido, sob pena de cercear o direito à ampla defesa das partes.

Até mesmo porque, como já dito anteriormente, a prova, mais que ao juiz, destinase ao convencimento do juízo, eis que, sem embargo das hipóteses de incidência do princípio da identidade física do juiz, a competência para o julgamento da causa se relaciona ao juízo e não à pessoa física do magistrado oficiante no processo, não sendo raras as hipóteses em que o juiz sentenciante é distinto do juiz que presidiu a instrução.

Além disso, força do duplo grau de jurisdição, caso qualquer das partes interponha recurso de apelação da sentença de primeiro grau, ou em caso de reexame necessário, o material probatório será submetido ao conhecimento do Tribunal competente, que, exercendo assim o denominado "juízo de revisão", terá a atribuição de reanalisar todo o acervo probatório e, com isso, pronunciar-se sobre a justiça da decisão prolatada em primeiro grau, devendo constar dos autos todos os elementos probatórios que o juiz e

\footnotetext{
${ }^{325}$ TARUFFO, Michele. Studi sulla rilevanza della prova, cit., p. 249; MITIDIERO, Daniel. Colaboração no processo civil: pressupostos sociais, lógicos e éticos, cit., p. 132-133; e DALL'ALBA, Felipe Camilo. A ampla defesa como proteção dos poderes das partes: proibição de inadmissão da prova por já estar convencido o juiz, cit., p. 102.
} 
também as partes reputem necessárias para a solução justa, dentro das regras do processo. Assim também é o posicionamento de Mitidiero:

"Na perspectiva do processo civil contemporâneo, o juiz não é dono da prova; essa serve antes ao juízo que ao juiz. Tendo em conta que há direito constitucional à prova no direito brasileiro, há direito das partes de aportar ao processo todos os elementos probatórios concernentes às alegações fáticas controversas, pertinentes e relevantes. Note-se: a desnecessidade de prova, a suportar o julgamento antecipado da lide, malgrado a jurisprudência do Superior Tribunal de Justiça, não pode assentar tão-somente no convencimento do magistrado. Dado que há direito fundamental à prova, como leciona Eduardo Cambi, o critério de seleção de necessidade ou de desnecessidade da prova recai na relação objetiva que se estabelece entre prova e thema probandum, à vista da exigência que conste no processo todos os elementos que as pessoas do juízo entendam necessárias para que se alcance uma solução jurídica justa." ${ }^{326}$

A questão da admissibilidade da prova, porquanto, não pode e não deve guardar relação com o convencimento do juízo, cuidando-se de questões a serem tratadas em momentos distintos.

\subsubsection{Submissão de toda e qualquer prova ao crivo das partes e outros deveres relacionados à instrução}

Há ainda uma questão elementar, e precedente a todas as demais, que consiste no dever do juiz submeter ao crivo das partes toda e qualquer prova aportada ao processo, seja a requerimento das próprias partes, ou até mesmo por iniciativa instrutória oficial.

Essa exigência, além de, evidentemente, inerente ao contraditório (no sentido ciência-oportunidade), é também resultado do viés democrático e publicista do processo, que exige que o seu resultado seja construído pelo juiz em coordenação com as partes interessadas, possibilitando-as influenciar, de maneira efetiva, sobre as possíveis decisões a serem proferidas.

O direito à prova, naturalmente, envolve a possibilidade das partes de produzir provas, contrapor-se ao requerimento da parte contrária (quando, por exemplo, a prova se mostrar ilícita, ilegítima, irrelevante, etc.) e ainda de produzir contraprova.

\footnotetext{
${ }^{326}$ MITIDIERO. Daniel. Comentários ao Código de Processo Civil. São Paulo: Memória Jurídica Ed., 2006. t. 3, p. 456-457.
} 
Assim, promovendo uma das partes a juntada extemporânea de determinados documentos aos autos, tal como ocorre, por vezes, na apresentação de alegações finais em primeiro grau, ou até mesmo na oferta de memoriais em segundo grau, previamente ao julgamento de eventual recurso, cumpre ao juiz adotar uma das seguintes opções.

Se a parte comprovar a impossibilidade de sua produção anterior, ou se se tratar de prova de fatos novos que devem ser considerados por força do artigo 462 do CPC, o juiz deverá intimar a parte contrária concedendo-lhe prazo razoável para manifestação e eventual contraprova (art. 398 e 399, CPC). Do contrário, verificada a extemporaneidade, deve o juiz determinar seu imediato desentranhamento dos autos.

Em qualquer dos casos, o certo é que será nula eventual decisão fundamentada em prova produzida nos autos, mas não submetida ao crivo das partes, ante a violação aos princípios da ampla defesa e do contraditório.

Komatsu $^{327}$ ainda, ao tratar dos deveres dos juízes, identifica dentre os denominados "deveres processuais de direção e desenvolvimenbto do processo" relacionados, especificamente, à prova, os seguintes: (i) dever de manter o princípio da concentração, (ii) de rejeitar a produção de prova inútil e de controlar sua admissibilidade, e de (iii) receber por si as diligências de prova.

No tocante ao princípio da concentração, reconhece a existência de um dever do juiz de garantir a unidade do processo e abreviar seu curso, notadamente na atividade probatória, "circunscrevendo-o ao menor número de atos o mais proximado entre si no tempo, a fim de obter-se a identidade física do juiz em todo seu curso”. No que se refere à admissibilidade da prova, reconhece o dever do juiz de não admitir prova inútil, de fato irrelevante, ou que se releve impossível ou insuscetível de ser objeto de prova, de modo a evitar a prática de atos inúteis em prejuízo à celeridade e economia processuais. Por fim, identifica o dever processual dos juízes de proceder direta e pessoalmente a colheita das provas (art. 446, II, CPC), de dirigir os trabalhos da audiência (art. 452, CPC), de inquirir as testemunhas (art. 414), proceder pessoalmente à inspeção judicial (art. 442), observando, assim, o princípio da imediação.

Como se disse inicialmente, não se pretende uma enumeração exaustiva dos deveres dos juízes em matéria probatória, mas apenas a demonstração de alguns exemplos colhidos no texto da lei, na doutrina e na jurisprudência, que ilustram as condutas exigíveis

\footnotetext{
${ }^{327}$ KOMATSU, Roque. Notas em torno dos deveres processuais dos juízes., cit., p. 717-720.
} 
dos juízes em sede de instrução processual, finalidade que se reputa alcançada pela exposição ora realizada.

\subsubsection{Limites: fator temporal do processo, natureza dos direitos controvertidos, limites objetivos da lide, tratamento isonômico das partes, responsabilidade do juiz e princípios da legalidade e da motivação das decisões judiciais}

Para encerrar esse tema, cumpre apenas retomar, sinteticamente, ideias já anteriormente expostas, referentes aos limites que são impostos pelo próprio ordenamento à atuação do magistrado na instrução processual.

A primeira delas é a de que, não obstante o reconhecimento dos deveres do juiz na instrução probatória, e do incremento qualitativo reconhecido às decisões quando pautadas por uma atuação interessada e participativa do juiz também na instrução, o processo não pode se prolongar indefinidamente, sendo que as exigências voltadas à pacificação social estabelecem limites também à atividade probatória ${ }^{328}$.

Assim, uma eventual extensão demasiada aos poderes-deveres instrutórios do juiz pode levar a um prolongamento do processo incompatível com a garantia da razoável duração, razão pela qual se impõe ao juiz que, diante das circunstâncias do caso concreto, aplique o princípio da proporcionalidade para verificar qual dos valores deve preponderar (solução justa x razoável duração do processo).

A segunda questão diz respeito à correlação entre os poderes-deveres instrutórios do juiz e o grau de disponibilidade dos interesses contrapostos no processo $^{329}$.

Se, por um lado, como já se disse, a iniciativa probatória oficial não viola, em nenhuma medida, o denominado "princípio dispositivo", a doutrina reconhece que o grau de intensidade da atuação do magistrado pode e, no mais das vezes, deve variar de acordo com a natureza dos interesses em jogo.

Assim, o próprio ordenamento jurídico autoriza, em regra, a intensificação dos poderes instrutórios nas lides que versam sobre direitos indisponíveis (já que nelas não se admite a presunção da veracidade dos fatos, mesmo diante, por exemplo, da revelia ou da

\footnotetext{
${ }^{328}$ Retomem-se, nesse aspecto, as considerações realizadas no Capítulo 1, item 1.4.

${ }^{329}$ Retomem-se, nesse aspecto, as considerações realizadas no Capítulo 4, item 4.1.1.
} 
recusa injustificada à exibição de documento) e, correlatamente, a atenuação do exercício desses poderes nas ações que tratam de direitos puramente disponíveis (nas quais, havendo confissão ficta, os poderes instrutórios do juiz somente devem ser utilizados em caso de ausência de verossimilhança das alegações ou de elementos probatórios contrários à presunção de veracidade, ou, ainda, quando verificado manifesto desequilíbrio entre os litigantes) ${ }^{330}$.

A terceira questão refere-se à necessidade de tratamento isonômico das partes.

Como já tratado anteriormente, por diversas razões, não vinga a tese de que o exercício dos poderes instrutórios do juiz importaria perda da imparcialidade do julgador e causaria desequilíbrio entre os litigantes. Contrariamente, o que entende, com apoio em substanciosa doutrina, é que a iniciativa instrutória do juiz constitui um importante instrumento para corrigir a desigualdade técnica e econômica muitas vezes verificada no plano prático entre os litigantes, de modo a evitar que ela possa repercutir no resultado do processo $^{331}$.

Para que não haja tratamento privilegiado a qualquer das partes, no entanto, é necessária a adstrição do juiz ao objeto do processo definido pelas partes na fase postulatória e, enfim, aos elementos constantes dos autos, o que constitui uma quarta limitação aos poderes-deveres do juiz na instrução.

Não pode o juiz, pois, a pretexto de exercer seus poderes-deveres instrutórios, avançar sobre matéria ou pedido não deduzido pelas partes, de sorte a alterar os limites objetivos da lide, nem pode agir como investigador particular dos fatos, investigando fontes de prova não mencionadas pelas partes e colhendo dados que extrapolem os limites da controvérsia fática instaurada dos autos.

Também a responsabilidade do juiz pelos atos praticados no processo, a ser tratada de forma mais detida no Capítulo 6, item 6.3 infra, constitui limite ao exercício dos poderes-deveres instrutórios do juiz, lembrando-se, como já se acenou anteriormente, que a todo aumento de poder acarreta o correlato aumento de responsabilidade. Assim, nas

\footnotetext{
${ }^{330}$ Nesse sentido: YARSHELL, Flávio Luiz. Antecipação da prova sem o requisito da urgência e direito autônomo à prova. cit., p. 124-125 e PUOLI, José Carlos Baptista. Os poderes do juiz e as reformas do processo civil, cit., p. 27.

${ }^{331}$ Retomem-se, nesse aspecto, as considerações realizadas no Capítulo 4, item 4.1.1.
} 
palavras de Amendoeira Jr., a responsabilidade do juiz serve como um "estímulo aos juízes para que tomem certos cuidados no exercício de suas funções" ${ }^{\text {332. }}$.

O autor, aliás, em estudo aprofundado sobre os poderes-deveres do juiz e suas vicissitudes, lembra ainda como limite os princípios da legalidade e da motivação das decisões, com fundamento no artigo 93, IX da Constituição Federal e artigos 126 e 127 do CPC, posicionando-se contrariamente à ideia de discricionariedade judicial, tema já abordado no Capítulo 4, item 4.1.1 supra.

Esses limites, por sua vez, permitem (i) evitar o arbítrio; (ii) verificar se a decisão vem eivada de subjetivismos; (iii) controlar o raciocínio do magistrado; (iv) permitir sua impugnação; (v) aumentar sua previsibilidade e também (vi) sua repercussão. E assim conclui:

"Daí a conclusão de que os princípios da legalidade e da motivação das
sentenças são verdadeiramente limitadores da atividade e dos poderes do
juiz e de que suas decisões deverão ser sempre fundadas na lei e poderão
ser sempre revistas, não existindo decisões imunes ou discricionárias,
mesmo porque nem mesmo no âmbito administrativo tem se admitido a
impossibilidade de revisão de decisões discricionárias, o que se dirá,
então, das decisões judiciais, sejam elas atinentes ao campo instrutório,
seja na concessão de medidas liminares, seja quando do preenchimento
de campos abertos. Ao juiz não é dado criar a lei - a figura do judge
made the law do direito norte-americano não encontra entre nós guarida -
no máximo, como dito, em certas situações, o juiz formulará juízos, não
'de oportunidade', mas de legalidade, já que tem sempre em vista e em
última análise a lei.,"333

Estas são, em nosso modo de entender, as limitações ao exercício dos poderesdeveres instrutórios do juiz no processo, servindo de baliza, ainda, para interpretar a extensão e os limites do que identificamos como "manifestações" do dever de colaboração imposto ao juiz na instrução probatória.

\footnotetext{
${ }^{332} \mathrm{~A}$ esse respeito, o autor acrescenta: “A possibilidade de responsabilização do Estado e do juiz é certamente uma medida preventiva e educativa, já que evita que os juízes, no exercício de suas funções, excedam os limites no uso dos poderes postos à sua disposição, 'esquecendo-se' de que estes não são apenas poderes desvinculados, como dito e repisado, verdadeiros poderes-deveres, oriundos dessa função”. (AMENDOEIRA JUNIOR, Sidnei. Poderes do juiz e tutela jurisdicional: a utilização racional dos poderes do juiz como forma de obtenção da tutela jurisdicional efetiva, justa e tempestiva, cit., p. 94).

${ }^{333}$ AMENDOEIRA JUNIOR, Sidnei. Poderes do juiz e tutela jurisdicional: a utilização racional dos poderes do juiz como forma de obtenção da tutela jurisdicional efetiva, justa e tempestiva, cit., p. 88.
} 


\subsection{Quanto às partes}

Sob a ótica da atuação das partes, a doutrina também identifica a existência de determinados deveres de conduta na instrução processual.

\subsubsection{Deveres de exposição dos fatos conforme a verdade, colaboração no seu esclarecimento e submissão aos poderes instrutórios do juiz}

Correlatamente ao incremento dos poderes diretivos e instrutórios do juiz, os sistemas processuais modernos passaram também a robustecer o conteúdo ético do processo, exigindo das partes uma conduta processual adequada, consentânea com a dignidade do processo enquanto instrumento da jurisdição, como já estudado no Capítulo 3 , supra.

Mas, para além da exigência de um comportamento ético em juízo, o processo civil contemporâneo vem se caracterizando cada vez mais pela busca de cooperação das partes para com a atividade judiciária, não apenas como forma de melhor legitimar os resultados, mas, principalmente, como instrumento para a melhoria qualitativa da solução jurídica ofertada $^{334}$.

Daí porque parcela da doutrina nacional reconhece a existência de um dever geral de colaboração, instituído no interesse do Estado para a realização dos escopos do processo, e cuja violação autoriza, inclusive, a aplicação de diversas espécies de sanção.

E, no que respeita à instrução processual e às atividades a ela afeitas, esse dever se relaciona e se exterioriza, inicialmente, através do dever de expor os fatos conforme a verdade em juízo, consagrado expressamente nos artigos 14, I, III e 17, II do CPC, o que foi objeto de nossa apreciação no Capítulo 3, item 3.2, supra.

Conforme anteriormente assentado, a finalidade precípua do dever de veracidade é evitar que o juiz profira decisão com base em convicção fundada em falsos subsídios trazidos pelas partes.

\footnotetext{
${ }^{334}$ PUOLI, José Carlos Baptista. Os poderes do juiz e as reformas do processo civil, cit., p. 47.
} 
Ademais, a alegação de fatos inverídicos pelas partes, além de trazer prejuízo à defesa da parte contrária, implica, no mais das vezes, desperdício de atividade processual, com perda de tempo e dinheiro na realização de atos e produção de provas absolutamente desnecessárias ao processo.

Esse dever geral de colaboração também se exterioriza, no processo civil brasileiro, através da exigência legal de colaboração no esclarecimento da verdade, expressamente estatuída pelo artigo 339, CPC, que dispõe que "ninguém se exime do dever de colaborar com o Poder Judiciário para o descobrimento da verdade”.

O dever de colaboração para esclarecimento dos fatos, segundo autorizada doutrina, é inerente ao monopólio da jurisdição e ao consequente dever geral de sujeição ao poder do Estado. Afinal, segundo Marinoni e Arenhart "se todos estão submetidos ao poder estatal, igualmente estão subjugados pela jurisdição, de forma a estarem constrangidos a colaborar com o Estado para a 'descoberta da verdade ${ }^{335}$.

E, a exemplo dos demais deveres éticos impostos no artigo 14, CPC, o dever de colaboração no esclarecimento da verdade é imposto não apenas às partes, mas a todos aqueles que participem do processo, ainda que de forma indireta e eventual.

Além disso, como já se disse, o comando do artigo 339 do CPC não constitui simples exortação para as partes e terceiros, nem tem mero conteúdo ético ou moral. Contrariamente, trata-se de comando legal e imperativo que, instuindo dever de conduta às partes e também a todos aqueles que participem do processo, possibilita a imposição de sanção diante de seu descumprimento.

Por fim, a colaboração das partes na instrução processual também se revela pela subsunção aos poderes instrutórios do juiz, que ora se identifica com uma simples sujeição, ora como um autêntico dever de conduta "ativa".

Com efeito, retomando o que já se disse ao tratarmos das posições jurídicas assumidas pelos sujeitos na relação jurídica processual ${ }^{336}$, segundo o entendimento de abalizada doutrina, a sujeição se limita a um pálido reflexo do poder exercido por outrem (no caso, a autoridade judicial). Não pressupõe, assim, sequer uma conduta do sujeito, quer comissiva ou omissiva, mas a simples impossibilidade de evitar os efeitos dos atos alheios.

\footnotetext{
${ }^{335}$ MARINONI, Luiz Guilherme; ARENHART, Sérgio Cruz. Prova, cit., p. 150-151.

${ }^{336}$ Confira-se Capítulo 2, item 2.2 supra.
} 
O exercício dos poderes instrutórios pelo juiz induz, portanto, à consequente sujeição das partes às suas consequências. É o que ocorre, por exemplo, quando o juiz determina a oitiva de testemunha referida ou a realização de perícia contábil com base nos documentos já aportados aos autos. Nesses casos, não há uma conduta ativa exigível das partes, mas sim a incidência de um efeito inelutável, contraposto à autoridade do juiz, que é a sujeição ao comando judicial.

Há hipóteses, no entanto, em que ao exercício dos poderes instrutórios do juiz corresponde não apenas uma simples sujeição das partes, mas sim um dever de conduta, de colaboração ativa, tal como ocorre quando o juiz determina a tomada de depoimento pessoal da parte, a juntada de determinado documento, a sua submissão (pessoal) a determinada prova pericial, etc. Não se trata aqui de apenas "tolerar" ou de se submeter às consequências da atividade probatória do juiz, impondo-se, mais do que isso, uma conduta ativa e efetiva das partes para a produção de determinada cuja realização foi determinada por iniciativa oficial.

As condutas processuais objetivas, exigíveis das partes na instrução em decorrência desse dever de colaboração serão tratadas nos item subsequente.

\subsubsection{Dever de comparecer em juízo e submeter-se a interrogatório ou depoimento pessoal, submeter-se à inspeção judicial e dar cumprimento às ordens judiciais}

De acordo com o artigo 340, CPC, no tocante especificamente à instrução processual, compete às partes: comparecer em juízo, respondendo ao que lhe for interrogado (inc. I), submeter-se à inspeção judicial que for julgada necessária (inc. II) e praticar o ato que lhe for determinado (inc. III).

Esses deveres, como decorre da própria dicção legal, se acrescem àqueles previstos no artigo 14, CPC, dentre os quais o de expor os fatos conforme a verdade e não produzir prova inútil ou desnecessária à defesa do direito. 
No que se refere ao comparecimento da parte em juízo (art. 340, inc. I), o CPC prevê duas hipóteses distintas, denominadas de interrogatório simples ${ }^{337}$, livre ${ }^{338}$ ou interrogatório da parte ${ }^{339}$ (art. 342, CPC) e depoimento pessoal (art. 343, CPC) ${ }^{340}$.

O interrogatório é determinado de ofício pelo juiz em qualquer tempo e fase processual, independentemente de requerimento da parte adversa e tem por objetivo obter esclarecimento sobre os fatos controvertidos, de sorte a propiciar um resultado justo ao litígio. O depoimento pessoal, por seu turno, deve ser requerido pela parte contrária no momento oportuno para requerimento das provas, ocorre, em regra, na audiência de instrução, e tem por finalidade precípua obter a confissão, espontânea ou provocada, da parte (daí o especial interesse da parte em seu requerimento).

Como observam Marinoni e Arenhart ${ }^{341}$, a imposição do art. 340, I, CPC, não se refere apenas ao oferecimento, pela parte, de resposta às perguntas que lhe forem dirigidas, mas também ao dever de comparecimento em juízo quando assim determinado. Nesse sentido, ainda que, em algumas hipóteses, a parte seja escusada de depor relativamente a certos fatos (art. 347, CPC), o que será tratado a seguir, tem o dever de comparecer em audiência para justificar a recusa e, se o caso, responder a outros fatos que lhe forem inquiridos.

Além disso, a parte, uma vez convocada a depor, tem o dever de veracidade quanto às respostas apresentadas, o que decorre da própria dicção do artigo 14, I, CPC, sendo equivocada a visão arraigada na praxe forense no que sentido de que esse dever se restringiria às testemunhas.

Tanto isso é verdade que mesmo a dispensa do dever de depor (art. 347, CPC), quando aplicável, não se confunde com o direito de mentir em juízo. A proteção que se dá quando presente uma regra de exclusão, em atenção a alguns interesses reputados mais relevantes (como a intimidade, o sigilo profissional, a proteção contra a auto-imputação criminosa, etc.), não exime o litigante de agir em juízo com lealdade, boa-fé e colaboração

\footnotetext{
${ }^{337}$ Cf. TABOSA, Fabio Guidi. In: MARCATO, Antonio Carlos (Coord.). Código de Processo Civil interpretado. 3. ed. São Paulo: Atlas, 2008. p. 1090.

${ }^{338}$ MARINONI, Luiz Guilherme; MITIDIERO, Daniel. Código de Processo Civil comentado. cit., p. 346.

${ }^{339}$ NERY JÚNIOR, Nelson, ANDRADE NERY, Rosa Maria. Código de Processo civil Comentado e Legislação processual civil extravagante, cit., p. 731.

${ }^{340}$ Há quem entenda tratarem-se, ambos, da mesma figura denominada depoimento pessoal. Cf. PONTES DE MIRANDA, Francisco Cavalcante. Comentários ao Código de Processo Civil. Rio de Janeiro: Forense, 1977. t. 4, p. 303-306.

${ }^{341}$ MARINONI, Luiz Guilherme; ARENHART, Sérgio Cruz. Prova, cit., p. 155.
} 
com o Poder Judiciário e "não gera um direito de conturbar a tarefa judicial da investigação dos fatos ${ }^{, 342}$.

Como já dito e repisado, se por um lado não se exige que a parte produza, espontaneamente, provas contra si, de outro, o ordenamento jurídico brasileiro também não lhe autoriza a empregar narrativa falsa dos fatos, afirmar em juízo, conscientemente, coisas contrárias à verdade, sonegar informações de tal forma que a versão dos fatos se torne inverídica, forjar provas ou suprimir outras que estejam ao seu alcance e cuja apresentação lhe seja determinada, etc. ${ }^{343}$.

Por essa razão, em caso de recusa injustificada de depor ou emprego de evasivas, além da consequência processual consistente na aplicação da pena de confissão (art. 343 e 345, CPC), entende parcela da doutrina que a parte também pode ser tida como infratora dos deveres de lealdade e boa-fé previstos no art. 14, II, CPC, ensejando a aplicação da pena de litigância de má-fé, ou até mesmo da multa prevista no artigo 14, parágrafo único, $\mathrm{CPC}$, dado o desatendimento à ordem judicial ${ }^{344}$.

Tais consequências, por sua vez, revelam-se como verdadeira sanção à conduta da parte (de natureza processual). Daí porque, dentre diversas outras razões, parte da doutrina considera o comparecimento em juízo e resposta à inquirição como verdadeiro dever processual da parte e não mero ônus. Nesse sentido, interessantíssimas são as considerações de Fabio Tabosa:

"O depoimento pessoal, como também o interrogatório simples, é um dever processual da parte, não mero ônus, dever que abrange não só o comparecimento em juízo como também a manifestação sobre o que for indagado na ocasião. A tal conclusão se chega, em primeiro lugar, pela inequívoca redação dos arts. 339 e 340 , quando tratam dos deveres de colaboração da parte para com o Judiciário com relação à descoberta da verdade; alie-se a isso a ideia de imposição presente nos arts. 342 e 343 e finalmente a não menos sintomática alusão do art. 347 aos fatos em relação aos quais não é obrigada a depor.

Há que se ter em mente, ainda, que o ônus processual, como exposto nos comentários ao art. 333, embora traduzindo a ideia de encargo, refere-se a uma conduta que a parte deve observar em seu próprio interesse, seja para a criação de uma situação de vantajosa, seja para evitar uma posição de desvantagem no processo. Não é o que ocorre no caso do depoimento

\footnotetext{
${ }^{342}$ MARINONI, Luiz Guilherme; ARENHART, Sérgio Cruz. Prova, cit., p. 155.

${ }^{343}$ Cf. TABOSA, Fabio Guidi. In: MARCATO, Antonio Carlos (Coord.). Código de Processo Civil interpretado, cit., p. 1084.

${ }^{344}$ Nesse sentido: TABOSA, Fabio Guidi. In: MARCATO, Antonio Carlos (Coord.). Código de Processo Civil interpretado, cit., p. 1093-1094.
} 
pessoal, em que o interesse envolvido na prova não é em absoluto o da parte que depõe, mas de seu adversário., ${ }^{345}$

Acrescenta o autor, ainda, outro relevante argumento no sentido de que, nas hipóteses de ônus previstas no ordenamento jurídico, a privação da vantagem ou a desvantagem sofrida pelo sujeito onerado constituem efeitos imediatos e naturais do respectivo desatendimento, tal como ocorre na hipótese de ausência de defesa, que faz com que permaneçam incontroversos os fatos alegados pelo autor e, por isso, dispensados de prova $^{346}$. Diversamente, no entanto, na recusa injustificada de prestar depoimento pessoal, a imposição da confissão nada tem de decorrência lógica natural da falta de depoimento, acarretando uma inversão na situação fática, já que de controvertidos os fatos passam a incontroversos. Nesse caso, portanto, a pena de confissão se apresenta como verdadeira sanção, pois traz um efeito extraordinário, criando uma ficção que subverte a condição anterior.

A submissão à inspeção judicial (art. 340, II, CPC), por sua vez, visa a viabilizar esse meio de prova quando determinado pelo juiz de ofício ou a requerimento da parte.

A inspeção judicial constitui meio de prova disciplinado nos artigos 440 a 443, CPC, que tem por objetivo possibilitar o contato direto do magistrado com pessoas ou coisas, a fim de se esclarecer sobre fato de interesse da causa. A inspeção juidicial deve envolver aspectos simples, que não demandem nem manifestação verbal da parte ou de terceiro (o que deve ser objeto de prova oral - depoimento pessoal das partes e oitiva de testemunhas), nem exame técnico aprofundado (o que demanda a produção de prova pericial).

A inspeção, por expressa disposição legal, pode ser determinada em qualquer fase do processo, em audiência de justificação prévia, antes ou depois de qualquer prova e até mesmo após o fim da audiência de instrução. Pode ser determinada, inclusive, em grau

\footnotetext{
${ }^{345}$ TABOSA, Fabio Guidi. In: MARCATO, Antonio Carlos (Coord.). Código de Processo Civil interpretado, cit., p. 1093-1094. Na mesma linha de entendimento: SANTOS, Moacyr Amaral. Primeiras linhas de direito processual civil. cit., v. 2, p. 439-440. Em sentido contrário, entendendo o depoimento pessoal como verdadeiro ônus processual, mas tratando a pena de confissão como autêntica sanção: DINAMARCO, Cândido Rangel. Instituições de direito processual civil. cit., v. 3, p. 646-648 e THEODORO JÚNIOR, Humberto. Curso de direito processual civil, cit, v. 1, p. 379-380.

${ }^{346} \mathrm{O}$ exemplo utilizado pelo autor nos parece de fato correto e adequado já que, em regra, é a observância, pelo réu, do ônus da impugnação especificada dos fatos que os torna controvertidos. Assim, se não são impugnados pelo réu, a narrativa empreendida pelo autor é tida como verdadeira.
} 
recursal, quando convertido o julgamento em diligência para a verificação de determinado fato.

A decisão que determina a inspeção judicial, tal como toda e qualquer outra decisão tomada no processo, deve ser devidamente fundamentada. Além disso, é garantido à parte assistir à inspeção, prestando esclarecimentos e observações reputadas necessárias, de forma a influenciar na formação da prova ${ }^{347}$.

No que se refere à inspeção sobre pessoas, a fim de prevenir que eventual recusa injustificada viesse a frustrar esse meio de prova, cujo resultado é de interesse da parte interessada em sua produção e também da própria jurisdição, o CPC erigiu a dever processual a sujeição pessoal da parte a essa inspeção.

As dificuldades com relação ao tema se colocam no tocante ao eventual conflito entre o dever de colaboração e o direito à intimidade, daí a necessidade de verificar, cauisticamente, a legitimidade de eventual recusa da parte. Para além disso, diante da garantia constitucional da liberdade e da também da intimidade, não se pode conduzir coercitivamente a parte a juízo para se submeter à inspeção corporal e nem constrangê-la à realização de exames que importem violação de sua esfera corporal ${ }^{348}$.

Assim, a eventual recusa injustificada da parte caracteriza violação ao dever de colaboração, autorizando, conforme o caso, a imposição de pena por litigância de má-fé (art. 17, IV ou V, CPC) ou até mesmo da multa prevista no artigo 14, parágrafo único, CPC, dado o desatendimento à ordem judicial. Poderá, ainda, haver consequências no campo probatório, entendendo a doutrina ora que o juiz deverá sopesar essa conduta no contexto dos autos, podendo dela retirar argumento de prova (indício) quanto ao fato a ser

\footnotetext{
${ }^{347}$ NERY JÚNIOR, Nelson, ANDRADE NERY, Rosa Maria. Código de Processo civil Comentado e Legislação processual civil extravagante, cit., p. 731.

${ }^{348}$ Nesse sentido: "Ninguém pode ser coagido ao exame ou inspeção corporal para prova no cível" (STFPleno, HC 71.373, Min. Marco Aurélio, j. 10.11.94, DJU 22.11.96. Também com relação ao tema Fabio Tabosa assim se posiciona: "supondo que a parte, mesmo sem justa causa, se recuse a se apresentar para a inspeção, ou a exibir determinadas partes do corpo, simplesmente não terá o juiz como obriga-la a tanto. Em relação às partes, antes de mais nada, não há disposição semelhante ao art. 412, CPC, que permite a condução coercitiva de testemunha, nem tampouco se afigura razoável conferir ao juiz o poder de determinar atos de força contra a própria pessoa, de modo a viabilizar o exame direto, prevalecendo nesse aspecto preceitos de ordem constitucional $\left(C F\right.$, art. $\left.5^{\circ}, X\right)$ ”. (TABOSA, Fabio Guidi. In: MARCATO, Antonio Carlos (Coord.). Código de Processo Civil interpretado, cit., p. 1085).
} 
esclarecido $^{349}$, ora, de forma mais enérgica, que essa recusa acarreta, por si só, presunção acerca dos fatos que se pretendia provar ${ }^{350}$.

Por derradeiro, o dever de praticar ato que lhe determinado (art. 340, III, CPC) corresponde a uma fórmula genérica adotada pelo legislador para se referir a todo e qualquer ato de interesse probatório que possa, de ofício ou a requerimento da parte, ser imputado às partes no curso do processo. Exemplos clássicos são a determinação de exibição de documento ou coisa que se ache em seu poder (art. 355, CPC) ${ }^{351}$ e a realização de exames médicos para fins periciais, tal como exames sanguíneos em ações de investigação de paternidade.

Em nosso ver, esse dever constitui natural desdobramento do dever geral de cumprimento das decisões judiciais previsto no artigo 14, V, CPC, já tratado em diversas passagens de nosso estudo.

E, as consequências da inobservância desse dever também vão desde consequências processuais, como é o caso da presunção de veracidade dos fatos que se pretendia provar com o documento cuja exibição foi injustamente desatendida (art. 359, CPC), como também pode ensejar a aplicação de pena por litigância de má-fé ou por descumprimento da ordem judicial e até mesmo a adoção de medidas coercitivas ou sub-rogatórias, a depender das circunstâncias de cada caso prático analisado, como será abordado no Capítulo 6 infra.

\subsubsection{Regras de exclusão}

Há casos, porém, em que não obstante a amplitude da previsão do artigo 339, CPC, a própria lei exonera a parte do dever de colaboração, em razão da proteção de outros interesses relevantes para a ordem jurídica e que acabam a ele sobrepondo em determinadas situações.

\footnotetext{
${ }^{349}$ TABOSA, Fabio Guidi. In: MARCATO, Antonio Carlos (Coord.). Código de Processo Civil interpretado, cit., p. 1404.

${ }^{350}$ MARINONI, Luiz Guilherme; ARENHART, Sérgio Cruz. Prova, cit., p. 802.

${ }^{351}$ Também tratando da exibição de documento determinada judicialmente como verdadeiro dever processual e não meramente ônus da parte: THEODODO JÚNIOR, Humberto. Curso de direito processual civil, cit., v. 1, p. 387 e PONTES DE MIRANDA, Francisco Cavalcanti. Comentários ao Código de Processo Civil. t. 4, p. 349.
} 
Essas hipóteses são denominadas comumente pela doutrina de "regras de exclusão", termo oriundo do direito norte-americano, e são previstas tanto no CPC, como em leis extravagantes que tratam especificamente de determinadas situações ou de determinadas categorias de pessoas ou informações, como é exemplo a lei que preserva o sigilo bancário (Lei Complementar 105/2001).

O dever de colaboração imposto por lei, portanto, cede em algumas hipóteses, ora a certos interesses ligados à defesa da esfera privada da pessoa, ora diante de outros deveres a que sujeitos os detentores das informações relevantes para o processo ${ }^{352}$.

Com relação ao depoimento pessoal, o art. 347, CPC determina que a parte não é obrigada a prestá-lo em duas situações: quando a respeito de fatos criminosos ou torpes que lhe forem imputados (inc. I) e em relação àqueles a cujo respeito deva guardar sigilo por estado ou profissão (inc. II).

No primeiro inciso, o artigo 347, CPC resguarda o privilégio contra a autoincriminação (auto-imputação criminosa), que é corolário do direito à liberdade constitucionalmente assegurado e também o direito de resguardo à sua reputação, quando os fatos objeto do depoimento forem reveladores de degradação moral. A esse respeito Marinoni e Arenhart observam que:

"O privilégio contra a autoincrimonação é garantia constitucional da liberdade. A exigência de que o acusado confesse seu crime ou de que pessoa indique fato que pode lhe resultar sanção penal é ofensiva à tendência universal que aponta para a necessidade de preservação da liberdade. ${ }^{353}$

Amaral Santos ressalva, no entanto, que essa exclusão refere-se apenas a fatos secundários da lide ou a fatos relevantes cuja prova possa ser feita sobre outra abordagem, que não a da imputação criminosa. Não se aplica, ao revés, quando o fato criminoso constitui o objeto central da lide ${ }^{354}$, ou seja, quando esteja em discussão o próprio fato delituoso e/ou suas consequências, tal como ocorre em ação indenizatória por acidente de

\footnotetext{
${ }^{352}$ TABOSA, Fabio Guidi. In: MARCATO, Antonio Carlos (Coord.). Código de Processo Civil interpretado, cit., p. 1404.

${ }^{353}$ MARINONI, Luiz Guilherme; ARENHART, Sérgio Cruz. Prova, cit., p. 151-153.

${ }^{354}$ SANTOS, Moacyr Amaral. Comentários do Código de Processo Civil. 6. ed. Rio de Janeiro: Forense, 1994. v. 4, p. 97.
} 
trânsito com lesão corporal, em ação indenizatória por contrafação de marca ${ }^{355}$, em ação de nulidade de título baseada na falsidade ou adulteração do documento particular, etc.

No segundo inciso o artigo 347, CPC resguarda o dever de sigilo por estado ou profissão. Essa hipótese de exclusão está, portanto, ligada ao resguardo de interesses de terceiros, normalmente estranhos ao processo, cujo sigilo a parte é obrigada a guardar.

O dever de sigilo por estado geralmente é associado diretamente ao sigilo religioso $^{356}$, ou seja, às informações prestadas pelos fiéis em confissão religiosa e ao dever moral de sigilo daí decorrente, que é reconhecido pelo direito como causa excludente do dever de depor. Tabosa ${ }^{357}$, no entanto, refere-se também ao estado familiar e aos vínculos de filiação e parentesco para reconhecer que, muito embora o dever de sigilo decorrente dessas relações não seja oriundo de lei, mas dos laços de lealdade e proteção recíprocos criados por força do núcleo familiar, cabe ao juiz, nesses casos, avaliar a razoabilidade da escusa de depor, considerando a proximidade entre o depoente e a pessoa a quem se refere o fato sigiloso, a natureza e gravidade do tema tratado, a natureza da causa, etc.

Aliás, o art. 229, CC, ao tratar das exclusões do dever de depor, prevê duas hipóteses fundadas justamente no vínculo familiar, a primeira em razão de desonra que o fato possa causar ao próprio depoente, a seu cônjuge, parente em grau sucessível ou amigo íntimo (inc. II) e a segunda na exposição dessas mesmas pessoas a perigo de vida, de demanda ou de dano patrimonial direto (inc. III). Muito embora a doutrina consultada não trate especificamente dessas hipóteses previstas no Código Civil, entendemos que as exclusões ali previstas são também aplicáveis ao depoimento pessoal, por se tratar de lei posterior ao CPC e que trata especificamente dessa matéria.

O dever de sigilo profissional, por sua vez, abarca uma gama de atividades profissionais, funções e ofícios ${ }^{358}$ nos quais, pela natureza da relação entre o depoente e a pessoa sobre a qual se deve depor, ou mesmo em razão da natureza das informações a serem prestadas, a lei ou o regulamento da profissão resguarda o sigilo. Diversos são os exemplos de sigilo profissional resguardado por lei, como é o caso do advogado em relação ao cliente, médicos e psicólogos em relação a seus pacientes, os sigilos de indústria e o sigilo empresarial, o sigilo do jornalista com relação à sua fonte, etc.

\footnotetext{
${ }^{355}$ Esses exemplos são de Fabio Tabosa, in Código de Processo Civil interpretado, cit., p. 1408.

${ }^{356}$ MARINONI, Luiz Guilherme; ARENHART, Sérgio Cruz. Prova, cit., p. 152.

${ }^{357}$ Nesse sentido: Fabio Tabosa, in Código de Processo Civil interpretado, cit., p. 1410.

${ }^{358}$ Fábio Tabosa classifica o sigilo religioso como espécie de sigilo profissional, em interpretação ao artigo

154 do Código Penal. Fabio Tabosa, in Código de Processo Civil interpretado, cit., p. 1410.
} 
Nessas hipóteses, a eventual quebra do sigilo por parte do depoente poderá caracterizar até mesmo ilícito penal (violação do segredo profissional), tipificado no artigo $154 \mathrm{CP}^{359}$.

Há casos, no entanto, em que a própria lei regulamentadora do exercício profissional excetua o sigilo legalmente garantido, como é exemplo o Código de Ética Médica (art. 102), que autoriza o médico a revelar informações sigilosas por justa causa, como é o caso de comunicação de doenças contagiosas. A própria intimação judicial para depor, aliás, geralmente é tida como causa legitimadora da revelação das informações.

Como advertem Marinoni e Mitidiero ${ }^{360}$, no entanto, o rol do artigo 347, CPC não é exaustivo, podendo o juiz analisar outras situações invocadas pelas partes como legitimadoras da escusa de depor (como são exemplo relações de parentesco próximo, depoimento sobre fatos íntimos e vexatórios, etc.), casos em que deverá ser aplicado o princípio da proporcionalidade para sopesar os eventuais valores em conflito, devendo-se evitar, no entanto, eventuais abusos que acabem por esvaziar esse importante meio de prova.

Cumpre ressalvar, ainda, que de acordo com o parágrafo único do dispositivo citado, essas hipóteses de exclusão não se aplicam às ações de filiação, de "desquite"361 e de anulação de casamento. Trata-se aqui, na realidade, das ações de família de forma geral que, por sua relevância e pela peculiaridade dos fatos nela tratados - cuja publicidade é restrita ao âmbito familiar - trazem uma natural maior dificuldade de prova, sendo certo que a aplicação das regras de exclusão acabaria, no mais das vezes, por inviabilizar por completo a obtenção das informações necessárias à solução justa da lide.

Também com relação à exibição de documentos a lei traz regras de exclusão - e ainda mais amplas - ao dever de colaboração das partes, arrolando no artigo 363, CPC, diversas hipóteses em que a parte pode escusar-se de exibir em juízo documento ou coisa.

A primeira delas consiste na hipótese de o documento cuja exibição é exigida seja “concernente a negócios da própria vida da família" (inc. I). Diante da amplitude da previsão legal, a doutrina apressa-se em fixar parâmetros para a apreciação judicial dessa

\footnotetext{
${ }^{359}$ Art. 154, CP: "Revelar alguém, sem justa causa, segredo, de que tem ciência em razão de função, ministério, ofício ou profissão, e cuja revelação possa produzir dano a outrem. Pena - detenção, de 3 (três) meses a 1 (um) ano, ou multa."

${ }^{360}$ MARINONI, Luiz Guilherme; MITIDIERO, Daniel. Código de Processo Civil comentado, cit., p. 351.

${ }^{361}$ Aqui se entendem as ações de separação e divórcio, em razão do novo tratamento da matéria dado pela Lei do Divórcio e pelo Código Civil em vigor.
} 
escusa, de sorte que a aplicação da norma legal não acabe, por sua abrangência, a inviabilizar a prova.

Tabosa, nesse contexto, afirma que a ratio legis desse inciso é resguardar a intimidade e a vida privada dos membros do núcleo familiar, ambos constitucionalmente tutelados (art. $5^{\circ}, \mathrm{X}, \mathrm{CF}$ ), "preservando o direito de seus integrantes de subtrair do conhecimento de terceiros aspectos relacionados às relações pessoais internas, ao cotidiano de seus membros e (...) a determinadas relações jurídicas entre/por eles estabelecidas ${ }^{\prime 362}$.

No entanto, como ressaltavam Marinoni e Mitidiero ${ }^{363}$, a escusa somente é possível se a parte demonstrar que a exibição da coisa ou documento relativo a "negócios" da família não tem relevância para o adequado julgamento do litígio. Entendimento contrário, segundo esses professores, levaria a ter por vedada qualquer ação que possa levar à discussão de questões íntimas da família, o que constituiria verdadeiro absurdo.

E, como exemplos de inadmissibilidade da recusa a doutrina cita o contrato firmado por pai e filho cuja exibição é requerida em ação proposta por terceiro e que visa à anulação do negócio jurídico; os litígios relacionados ao direito de família e a questões de estado, em que as questões íntimas dos entes familiares constituem o próprio objeto central das ações; a exibição de registros contábeis de empresa familiar em litígio travado com terceiros por força de negócios por eles realizados, etc ${ }^{364}$.

A segunda regra de exclusão refere-se à hipótese de a "apresentação puder violar dever de honra" (inc. II). Dada a similitude, ao menos em parte, entre a previsão do inciso II e do inciso III a seguir tratado, entende-se que a violação à honra aqui aludida se refere não ao conteúdo das revelações, mas ao próprio ato de mostrar/divulgar.

A hipótese aqui tratada, pois, é a do dever moral, o comprometimento pessoal de sigilo com relação ao documento, que foi assumido pelo detentor junto a terceiro, e cuja revelação, portanto, abalaria sua credibilidade e sua reputação perante esse terceiro. Como exemplos Tabosa cita a situação daquele que recebe em caráter não profissional um manuscrito inédito para exame e apreciação; daquele que se acha na posse de fita

\footnotetext{
${ }^{362}$ TABOSA, Fabio Guidi. In: MARCATO, Antonio Carlos (Coord.). Código de Processo Civil interpretado, cit., p. 1166.

${ }^{363}$ MARINONI, Luiz Guilherme; MITIDIERO, Daniel. Código de Processo Civil comentado, cit., p. 363.

${ }^{364}$ TABOSA, Fabio Guidi. In: MARCATO, Antonio Carlos (Coord.). Código de Processo Civil interpretado, cit., p. 1166.
} 
magnética com a gravação do conteúdo de reunião secreta de grupo qualquer como partido político, sindicato, etc ${ }^{365}$.

A terceira regra de exclusão refere-se à possibilidade da "publicidade do documento redundar em desonra à parte ou a terceiro, bem como seus parentes consanguíneos ou afins até o terceiro grau; ou lhes representar perigo de ação penal”. O inciso, como se vê, trata de duas hipóteses distintas: desonra à parte ou a terceiro e risco de ação penal.

No primeiro aspecto, a lei trata da desonra que possa trazer à parte ou parente próximo o próprio conteúdo do documento e não de sua mera revelação (como alude o inciso II). Trata-se aqui da tutela da honra, enquanto atributo da personalidade também constitucionalmente garantido, e que pode ser comprometida pela demonstração de alguma prática irregular ou contrária à reputação de determinada pessoa no meio social.

Como bem observam Marinoni e Arenhart ${ }^{366}$, essa excludente também se aplica às pessoas jurídicas, já que a publicidade de determinado documento, a depender de seu conteúdo, pode vir a sua atingir a imagem, reputação e confiabilidade econômica.

A segunda parte do inciso se refere ao privilégio contra a auto-incriminação, já tratado anteriormente no que se refere à escusa de prestar depoimento pessoal. Cumpre apenas registrar, nesse aspecto, a necessidade de que a recusa seja fundada na possibilidade concreta de incriminação, ou seja, na possibilidade de que o documento gere evidência do ilícito penal cometido, ou seja, que haja flagrante situação de perigo de ação penal ${ }^{367}$.

A quarta regra de exclusão refere-se à possibilidade de a exibição "acarretar $a$ divulgação de fatos, a cujo respeito, por estado ou profissão, devam guardar sigilo”. Essa questão também já foi anteriormente tratada ao analisarmos as escusas de prestar depoimento pessoal, aplicando-se aqui o que já foi anteriormente abordado neste item.

Por fim, o inciso V, valendo-se de uma norma aberta, prevê a possibilidade de escusa de apresentação do documento quando "subsistirem outros motivos graves que, segundo o prudente arbítrio do juiz, justifiquem a escusa da exibição”.

Assim como já se disse em relação à exclusão do dever de prestar depoimento pessoal, diante da impossibilidade de previsão, pelo legislador, de todas as situações que

\footnotetext{
${ }^{365}$ TABOSA, Fabio Guidi. In: MARCATO, Antonio Carlos (Coord.). Código de Processo Civil interpretado, cit., p. 1167.

${ }^{366}$ MARINONI, Luiz Guilherme; ARENHART, Sérgio Cruz. Prova, cit., p. 513.

${ }^{367}$ MARINONI, Luiz Guilherme; MITIDIERO, Daniel. Código de Processo Civil comentado, cit., p. 363.
} 
podem gerar a justa recusa de exibição, justifica-se a inclusão da norma aberta, a permitir ao julgador no caso concreto sopesar os interesses eventualmente em conflito, notadamente o interesse que se pretende preservar com a confidencialidade do documento e o interesse público na obtenção da prova, levando em conta, evidentemente, a natureza e relevância da prova para o processo para, com base nesses elementos, decidir sobre a legitimidade ou não da recusa da parte em disponibilizá-la. 


\section{CONSEQUÊNCIAS DA INOBSERVÂNCIA DO DEVER DE COLABORAÇÃO NA INSTRUÇÃO PROCESSUAL}

\subsection{Consequências processuais: o valor probatório do comportamento processual das partes}

As consequências impostas à violação do dever de colaboração das partes podem assumir diferentes formas no processo. Em matéria probatória, a primeira consequência geralmente atribuída ao déficit de colaboração da parte no esclarecimento dos fatos controvertidos consiste na presunção de veracidade do fato que se pretendia provar.

Como já se mencionou no Capítulo 5, item 5.2.2 supra, em determinadas hipóteses a própria lei atribui consequência probatória contrária à parte que se recusa a colaborar para o esclarecimento da verdade, tomando a recusa como indicativo do interesse em ocultar provas cujo resultado lhe seria desfavorável.

É o que se verifica, exemplificativamente, nos casos de recusa injustificada de prestar depoimento pessoal (art. 343, § $2^{\circ}, \mathrm{CPC}$ ) e da recusa ilegítima à exibição de documento determinada pelo juiz (art. 359, CPC), para os quais a lei estabelece, diretamente, a presunção (legal) de veracidade dos fatos que se pretendia provar com o depoimento ou com o documento omitido, como forma de obviar a lacuna probatória oriunda do comportamento desinteressado da parte.

A presunção legal derivada de tais situações é iuris tantum, o que significa que o juiz não está a ela vinculado, podendo julgar contrariamente se convencido do contrário pelo conjunto probatório, ou mesmo determinar, quando possível, a produção de outra prova que substitua aquela negada pela parte. No entanto, como reconhecem Marinoni e Arenhart $^{368}$, a incidência dessa presunção traz significativo prejuízo probatório à medida que, na prática, dificilmente a parte conseguirá se desfazer de seus efeitos.

Há casos, ainda, em que a lei, ao invés de estabelecer diretamente a presunção, autoriza o juiz a fazê-lo, extraindo consequências probatórias do comportamento da parte (presunção hominis). É o que se verifica, por exemplo, quando a parte, apesar de comparecer à audiência designada para a tomada do depoimento pessoal, emprega evasivas

${ }^{368}$ MARINONI, Luiz Guilherme; ARENHART, Sérgio Cruz. Prova, cit., p. 156. 
ou deixa de responder ao que lhe é perguntado, hipótese em que o juiz, analisando esse comportamento em conjunto com os demais elementos de prova constantes dos autos, deve avaliar se houve recusa de depor, aplicando, em caso afirmativo, a presunção de veracidade do fato que se pretendia prova (art. 345, CPC).

A questão ora analisada - quanto às consequências probatórias da falta de colaboração - insere-se, portanto, como claramente se vê, em tema mais amplo, consistente na eficácia probatória do comportamento das partes no processo ${ }^{369}$.

A ciência processual vem aceitando modernamente a possibilidade de o comportamento das partes em juízo produzir convencimento. Nesse sentido, o comportamento das partes, revelado através de atos que praticam no processo, e das atividades que omitem, é tido como fato jurídico que pode apresentar relevância probatória $^{370}$.

A faculdade do juiz de valorar o comportamento processual da parte, aliás, é tida como uma das conquistas mais importantes do processo civil moderno ${ }^{371}$ e constitui comando legal expresso no ordenamento de vários países, dentre os quais pode se citar, a título exemplificativo, o da Itália ${ }^{372}$, da Colômbia ${ }^{373}$ e do Peru ${ }^{374}$, dentre outros.

No ordenamento jurídico brasileiro, além das previsões legais anteriormente citadas, destacam-se ainda os artigos $231^{375}$ e $232^{376}$ do $\mathrm{CC}$ em vigor que, encampando

\footnotetext{
${ }^{369}$ A esse respeito, consultar: CAPPELLETTI, Mauro. Valor actual del principio de oralidade: la oralidad y las pruebas en el proceso civil. Trad. Santiago Santis Melendo. Buenos Aires: Ejea, 1972. cap. 5, n. 4, p. 151 e ss.; GORLA, Gino. Comportamento processuale dele parti e convencimento del giudice. Rivista di Diritto Processuale, Milano, n. 12, p. 24 e ss, 1935; DEVIS ECHANDÍA, Hernando. Teoria general de la prueba judicial. 5. ed. Buenos Aires: Zavalia, 1981. t. 2, n. 384, p. 679 e ss.

${ }^{370}$ RIGHI, Ivan. Eficácia probatória do comportamento das partes. Revista da Faculdade de Direito da UFPR, Curitiba, n. 20, 1981.

${ }^{371}$ MEDINA, Paulo Roberto de Gouvêa. A prova das intenções no processo civil. Revista de Processo, Rio de Janeiro, ano 29, n. 115, p. 74-85, maio/jun. 2004.

372،Art. 116: O juiz pode extrair argumentos de prova das respostas das partes ao interrogatório informal, da recusa injustificada em consentir as inspeções ordenadas e, em geral, do comportamento que mantenham no processo" (tradução livre).

373، Art. 249. La conducta de las partes como indicio. El juex podrá deducir indícios de la conducta procesal de las partes."

374، “Artículo 282 - Presunción y conducta procesal de las partes - El Juez puede extraer conclusiones en contra de los interesses de las partes atendiendo a la conducta que estás asumen em el processo, particularmente cuando se manifesta notoriamente em el falta de cooperación para lograr la finalidad de los médios probatórios, o com otras actitudes de obstrucción."

375،Art. 231. Aquele que se nega a submeter-se a exame médico necessário não poderá aproveitar-se da sua recusa."

376، Art. 232. A recusa à perícia médica ordenada pelo juiz poderá suprir a prova que se pretendia obter com o exame."
} 
entendimento já consolidado - e inclusive sumulado ${ }^{377}$ - em sede jurisprudencial atribuem força probatória à recusa injustificada da parte a se submeter à perícia médica ordenada pelo juiz.

A solução adotada pela lei decorre da ponderação de dois interesses em conflito. De um lado, tem-se a necessidade de produção dessa prova (perícia médica) para a solução de algumas espécies de litígio, o que se verifica não apenas em ações investigatórias de paternidade, mas em todas quantas haja necessidade de exame científico que envolva conhecimentos biológicos relativos a uma das partes. De outro, verifica-se que a submissão do demandado, a manu militari, à extração de determinado material ou tecido de seu corpo, ou mesmo sua submissão forçada a exame clínico corporal, atenta contra a consciência jurídica em geral, configurando, ainda, no entender majoritário da doutrina, violação às garantias constitucionais da intimidade, da dignidade da pessoa humana e da intangibilidade física ${ }^{378}$.

Assim, a extração de consequência probatória do comportamento da parte foi a solução encontrada pelo legislador para, a um só tempo, estimular a colaboração das partes no esclarecimento dos fatos e, de outro, solucionar a lacuna probatória decorrente de sua eventual omissão.

Barbosa Moreira, ao analisar os artigos de lei em questão, alerta, no entanto, que consequência probatória decorrente da recusa da parte à realização da perícia médica é resultado possível, porém não necessário e automaticamente decorrente da lei, o que se extrai da própria redação do art. 232, CC, que determina que a recusa "poderá suprir" e não "suprirá" a prova que se pretendia produzir" ${ }^{379}$. Ou seja, a lei, com base nesse comportamento da parte, possibilita ao juiz uma presunção hominis, que somente se desfaz mediante prova em contrário em favor da outra parte ${ }^{380}$.

\footnotetext{
${ }^{377}$ Súmula 301 STJ: "Em ação investigatória, a recusa do suposto pai a submeter-se ao exame de DNA induz presunção iuris tantum de paternidade."

${ }^{378} \mathrm{Em}$ sentido contrário, entendendo que a dignidade da pessoa humana e a intangibilidade corporal devem, por vezes, ceder ao direito de estado de filiação, ao direito à origem genética e ao direito à prova do outro litigante v. FERREIRA, William dos Santos. Princípios fundamentais da prova cível, cit., p. 68-72 e MARINONI, Luiz Guilherme; ARENHART, Sérgio Cruz. Prova, cit., p. 184-186, embora estes últimos sustentem a ideia apenas no que se refere à recusa de terceiro, admitindo que seja constrangido fisicamente à realização da perícia.

${ }^{379}$ BARBOSA MOREIRA, José Carlos. La negativa de la parte a someterse a una pericia medica (según el nuevo Código Civil brasileño). In: Temas de direito processual: nona série. São Paulo: Saraiva, 2007. p. 159-166.

${ }^{380}$ RIBEIRO, Darci Guimarães. O sobreprincípio da boa-fé processual como decorrência do comportamento da parte em juízo, cit., p. 71-87.
} 
Assim, segundo o eminente professor, diante da recusa da parte à submissão à prova pericial, deve o juiz, no caso concreto, ponderar se a negativa constitui indício suficientemente grave para dar lugar à presunção do fato probando, levando em conta eventuais elementos de convicção em sentido oposto, que possam contrabalancear o peso desse indício na mente do julgador ${ }^{381}$.

Se a resposta desse exercício mental for positiva, o juiz deverá dar por suprida a prova, o que equivalerá à sua prática com resultado contrário à parte recalcitrante. Caso contrário, se convencido do oposto pelas demais provas dos autos, mesmo diante da ausência da prova pericial, deverá o juiz julgar favoravelmente ao renitente. Mas nesse caso deve o juiz demonstrar os motivos de sua convicção com apoio nas demais provas do processo, não podendo assim julgar simplesmente pela ausência da prova pericial. Essa a interpretação conjugada dos artigos 231 e 232, CC.

Em suma: a parte que tem o ônus da prova não pode ser prejudicada pelo comportamento negativo da outra. Assim, a recusa injustificada retira o ônus da prova da parte que a requereu, sendo que esta que somente não logrará êxito, nessa hipótese, se o contrário for provado por outro meio nos autos.

Nas palavras de Barbosa Moreira "o autor pode sair vencido apesar da negativa do demandado, mas este não pode ter sucesso por causa de sua negativa” ${ }^{382}$. Daí porque, em seu entender, a ordem dos dispositivos em questão deveria ser invertida, ou então, deveria ter o legislador optado por regular a matéria em um único dispositivo, com a seguinte redação: “A recusa à perícia médica ordenada pelo juiz poderá suprir a prova que se pretendia obter com o exame; e, ainda quando não a supra, não poderá aproveitar à parte que se recusou”.

Como se vê, com apoio em prestigiosa doutrina, é grande a influência que o comportamento das partes em juízo produz no magistrado, podendo ter, inclusive, enquanto fato jurídico processual, influência na formação da convicção judicial.

Echandía $^{383}$, nessa mesma linha de entendimento, classifica a consideração do comportamento processual das partes como "precioso" instrumento a ser empregado na

\footnotetext{
${ }^{381}$ Barbosa Moreira cita como exemplo a hipótese de, em ação de investigação de paternidade, o suposto pai, apesar de recusar-se à realização do teste de DNA, demonstrar por outro meio de prova sua impotência generandi ao tempo da concepção.

${ }^{382}$ BARBOSA MOREIRA, José Carlos. La negativa de la parte a someterse a una pericia medica (según el nuevo Código Civil brasileño), cit., p. 164.

${ }^{383}$ DEVIS ECHANDÍA, Hernando. Teoria general de la prueba judicial, cit., t. 1, p. 114.
} 
valoração das provas, cabendo empregá-o seja em sistemas orientados pelo princípio inquisitivo ou mesmo dispositivo.

A matéria, no entanto, suscita relevantes indagações no diz respeito à necessidade ou não de previsão legal expressa dos comportamentos com eficácia probatória e ao valor que deve ser dado a esse elemento de convicção.

Com efeito, em diversas hipóteses, dentro e fora do campo probatório, a lei brasileira extrai consequências processuais de determinados comportamentos das partes em juízo. Exemplos clássicos são a presunção de veracidade dos fatos alegados decorrente da revelia (art. 319), a presunção de veracidade e autenticidade de documento particular não impugnado (art. 372), a própria preclusão temporal, que impede a realização do ato processual (art. 183), a presunção de veracidade do fato que se pretendia provar, decorrente da recusa injustificada da parte intimada a depor (art. $343, \S 2^{\circ}$ ), etc.

Contudo, diferentemente de outros ordenamentos jurídicos estrangeiros, como é o caso do italiano, colombiano e peruano já citados, assim como do alemão, o CPC brasileiro, a par das disposições específicas já citadas, não contém uma norma expressa que insira o comportamento processual da parte como elemento do conjunto probatório ou como uma prova típica. Esse fato, então, retiraria a possibilidade de atribuir eficácia probatória a outros comportamentos processuais não citados em lei?

A doutrina processual contemporânea, respondendo negativamente a essa indagação ${ }^{384}$, fundamenta sua resposta nos princípios da atipicidade da prova, do livre convencimento motivado e na permissão legal do emprego das "máximas da experiência" pelo juiz ${ }^{385}$.

Com efeito, como já se abordou anteriormente, o CPC brasileiro não somente recepciona o princípio da valoração racional da prova (art. 131) como também o da atipicidade dos meios de prova, admitindo todos os meios legais e moralmente legítimos como hábeis à demonstração dos fatos (art 332), não havendo hierarquia entre os meios de prova, nem dirigismo legal na valoração de seu produto final, salvo alguns resquícios de

\footnotetext{
${ }^{384}$ Nesse sentido: MEDINA, Paulo Roberto de Gouvêa. A prova das intenções no processo civil, cit., p. 7485, MARINONI, Luiz Guilherme; ARENHART, Sérgio Cruz. Prova, cit., p. 184-186, FERREIRA, William dos Santos. Princípios fundamentais da prova cível, cit., p. 68, RIGHI, Ivan. Eficácia probatória do comportamento das partes, cit., RIBEIRO, Darci Guimarães. O sobreprincípio da boa-fé processual como decorrência do comportamento da parte em juízo, cit., p. 71-87.

${ }^{385}$ Pelos mesmos motivos, aliás, aceitava-se a eficácia probatória do comportamento das partes ao tempo do Código de Processo Civil Italiano de 1865, que, diferentemente do atual, não continha disposição específica nesse sentido. A esse respeito, v. GORLA, Gino. Comportamento processuale dele parti e convencimento del giudice, cit., p. 24 e ss.
} 
prova legal (que, em muitos casos, na realidade, se confunde com a forma do ato jurídico, questão ligada ao direito material e não processual).

Além disso, o CPC determina ao juiz que aprecie a prova "atendendo aos fatos $e$ circunstâncias constantes dos autos" (art. 131), assim como autoriza o emprego das máximas da experiência (art. 335), as quais, nas palavras de Dinamarco, correspondem à "expressão da cultura dos juízes como intérpretes dos valores e da experiência acumulada pela sociedade em que vivem" ${ }^{386}$.

Dinamarco, nesse sentido, conclui que os artigos 231 e 232 do CC, apesar de aparentemente pontuais em sua redação, abrem caminho a uma interpretação mais proveitosa do art. 335, CPC, permitindo considerar incluída neste a máxima segundo a qual “o comportamento da parte no processo pode ser tomado como elemento de convicção para a apreciação da matéria de fato pelo juiz",387.

Moniz de Aragão, em apoio a esse entendimento, ao comentar o artigo 332 do CPC, citando Carlo Furno, assente que seria "especialmente supérflua qualquer norma legal expressa que obrigue ou proíba o juiz de tomar em consideração, no momento de sentenciar, a conduta processual das partes. "388

No tocante ao valor que deve ser dado a esse elemento de convicção, a doutrina nacional parece se posicionar predominantemente no sentido de que o comportamento processual da parte constitui um indício, que serve de fonte para uma presunção hominis.

Ferreira $^{389}$, nesse sentido, afirma que os comportamentos processuais das partes integram o grupo das provas atípicas, servindo como um indício, eis que o juiz parte de um fato conhecido (comportamento da parte) para um desconhecido (presumido), empregando, para tanto, as máximas da experiência para chegar a uma conclusão quanto ao fato probando $^{390}$.

\footnotetext{
${ }^{386} \mathrm{E}$ prossegue: "Atentos e sensíveis às realidades do mundo, eles têm o dever de captar pelos sentidos e desenvolver no intelecto o significado dos fatos que os circundam na vida ordinária, para traduzir em decisões sensatas aquilo que o homem comum sabe e os conhecimentos que certas técnicas elementares lhe transmitem" (DINAMARCO, Cândido Rangel. Instituições de direito processual civil, cit., 6. ed., v. 3, p. 122).

${ }^{387}$ DINAMARCO, Cândido Rangel. Instituições de direito processual civil, cit., 6. ed., v. 3, p. 124.

${ }^{388}$ ARAGÃO, E. D. Moniz. Regras de prova no Código Civil. Revista de Processo, Rio de Janeiro, ano 29, p. 21, n. 116, jul./ago. 2004.

${ }^{389}$ FERREIRA, William dos Santos. Princípios fundamentais da prova cível, cit., p. 68.

${ }^{390}$ Também esse é o entendimento de José Carlos Barbosa Moreira, cf. BARBOSA MOREIRA, José Carlos. Provas atípicas. Revista de Processo, São Paulo, v. 19, n. 76, p. 114-126, out./dez. 1994; ARAGÃO, E. D. Moniz. Regras de prova no Código Civil, cit., p. 21, e MARINONI, Luiz Guilherme; ARENHART, Sérgio Cruz. Prova, cit., p. 184-186.
} 
As presunções hominis, por sua vez, ainda na lição do professor, não constituem propriamente um meio de prova, mas sim meio liberatório do ônus de provar - sucedâneo de prova - que leva a um convencimento sobre o fato não demonstrado (mas simplesmente presumido) em razão do ordinariamente ocorre. Assim, a parte é beneficiada pelo fato presumido, cabendo o ônus da prova de sua inocorrência à parte contrária, exceto se o contrário resultar do conjunto probatório, pouco importando, para tanto, o responsável pela produção da prova nos autos, dada a incidência do princípio da comunhão da prova.

Também Dinamarco afirma que, a despeito da má-redação do art. 212, IV, CC, a presunção não é meio de prova, ou seja, não consiste em técnica de exame das fontes probatórias, mas constitui, isto sim, "processo de raciocínio dedutivo que leva a concluir que um fato aconteceu, quando se sabe que outro haja acontecido"391.

No mais, a própria lei impede a incidência dessa presunção nos casos em que exclui a prova testemunhal, entendendo-se que, se não se admite a prova exclusivamente testemunhal, não se pode autorizar o juiz a empregar o que ordinariamente acontece.

Cumpre ressalvar, ainda, que a presunção hominis, mesmo que autorizada por nosso ordenamento, não se confunde com "juízos sensoriais”, não se admitindo julgamento de acordo com percepções de sensações pelo juiz ou meras subjetividades ou impressões pessoais.

Nesse sentido, como bem adverte Righi, com fundamento no pensamento de Gorla, ainda que não se ignore a influência psicológica que o modo de agir das partes em juízo possa acarretar no juiz, ele somente está autorizado a extrair eficácia probatória de comportamentos processuais que permitam ilações racionais, exigindo-se, ainda, "univocidade de indícios e segurança na presunção". Veja-se:

"Interessa, isto sim, o comportamento processual que permite ilações racionais, de conteúdo probatório, úteis para a decisão da lide. Vale dizer, a conduta que - encarada pelo juiz como fato processual - sirva de indício e propicie, mediante o emprego de critério lógico-dedutivo, uma conclusão acerca de questão importante ao equacionamento do litígio." ${ }^{392}$

Além disso, a doutrina majoritária defende que a eficácia probatória do comportamento da parte deve ter relação com a produção de prova e não com seu comportamento em geral no processo. Assim, o comportamento desleal, a má-fé, o ato

\footnotetext{
${ }^{391}$ DINAMARCO, Cândido Rangel. Instituições de direito processual civil, cit., 6. ed., v. 3, p. 125-126.

${ }^{392}$ RIGHI, Ivan. Eficácia probatória do comportamento das partes, cit., p. 4.
} 
atentatório à dignidade da justiça podem dar causa a sérias consequências já analisadas no Capítulo 3 infra, mas não constituem, por si só, elementos capazes de produzir eficácia probatória.

Essas observações, de seu turno, corroboram a fundamental importância da exigência constitucional da fundamentação da decisão, que, no caso específico, funciona como elemento indispensável de controle, pelas partes, da operação lógica efetuada pelo juiz, possibilitando, em grau de recurso, o questionamento sobre a eficácia probatória dos fatos jurídicos tomados como premissas da decisão e o acerto da conclusão obtida pelo juiz $^{393}$.

\subsection{Sanções pecuniárias, medidas de sub-rogação e medidas coercitivas}

Como se viu no item anterior, a inobservância do dever de colaboração imposto às partes no processo civil brasileiro enseja, geralmente, a presunção de veracidade dos fatos que se pretende provar.

Essa presunção, todavia, se por um lado não é aplicável em todas as hipóteses de descumprimento do dever de colaboração, por outro, não esgota as consequências às partes de sua inobservância.

Com efeito, como já acenado no Capítulo 2, item 2.3.3, versando o litígio sobre direitos indisponíveis, o ordenamento processual, em virtude da relevância dos interesses em conflito, não admite a presunção de veracidade dos fatos diante, por exemplo, da ausência de contestação, da recusa injustificada de prestar depoimento pessoal, da recusa de exibir documentos, etc.

A falta de colaboração nessas hipóteses, pois, não é superável mediante o recurso à eficaz técnica da confissão ficta, ligada ao conceito de ônus, e que auxilia o juiz na prolação da decisão quando o acervo probatório não se mostra suficiente para a formação de seu convencimento. Em casos tais, parcela da doutrina defende a possibilidade de emprego de aplicação de medidas coercitivas ou mesmo de sub-rogação, como forma de

\footnotetext{
393، “em se tratando de presunção simples, é indispensável que o juiz revele, na fundamentação do pronunciamento decisório, o raciocínio que o levou a extrair consequências probatórias do comportamento das partes. Sem isso, com efeito, não será possível o controle da operação lógica efetuada." RIGHI, Ivan. Eficácia probatória do comportamento das partes, cit., p. 9.
} 
suprir a ausência de colaboração da parte e ensejar ao julgador a possibilidade de esclarecimento dos fatos controvertidos ${ }^{394}$.

Nesse mesmo sentido é o pensamento de Yarshell. Veja-se:

"Uma outra hipótese na qual a imposição do ônus poderia autorizar, sempre em matéria de prova, a concomitante vigência de um dever poderia ser identificada, agora mais consistência, nos casos de direitos indisponíveis, para os quais já se acenou. Nestes, diante da inércia da parte - de sua falta de cooperação ou de colaboração -, não se pode extrair efeitos desfavoráveis consistentes no reconhecimento de fatos alegados por seu adversário. Isso pode levar, inclusive, à adoção de medidas coercitivas - notadamente à imposição de multa diária - ou até mesmo de sub-rogação- como no caso da busca e apreensão de coisas e documentos que a parte se recuse a exibir." 395

Outro exemplo colhido na doutrina, citado por Marinoni e Arenhart ${ }^{396}$, no qual também não tem aplicação a presunção de veracidade decorrente da ausência de colaboração, diz respeito a um determinado litígio em que se verifica a necessidade de exibição de um importante documento para a apuração do valor de determinada coisa.

Nessa hipótese, independentente de versar o litígio sobre interesses disponíveis, sendo imprescindível a informação contida no referido documento (ex: contrato particular), sem a qual não será possível atingir o valor buscado, de nada serve a presunção decorrente do art. 359, CPC, transformando-se tanto as medidas coercitivas como a ordem de busca e apreensão do documento como alternativas cabíveis a fim de se atingir o resultado perseguido pela atividade probatória.

O mesmo se aplica, em nosso entender, no caso de a presunção de veracidade, gerada pela ausência de colaboração na produção de determinada prova, levar a um resultado absurdo ou manifestamente inverossímil, caso em que o juiz poderá se valer das denominadas "medidas de apoio" do art. 461, CPC, para incentivar a parte a cumprir o comando judicial e, com isso, tornar possível a realização da prova inicialmente frustrada pela ausência de colaboração.

\footnotetext{
${ }^{394}$ Nesse sentido: MARINONI, Luiz Guilherme; ARENHART, Sérgio Cruz. Prova, cit., p. 513 e FERREIRA, William dos Santos. Princípios fundamentais da prova cível, cit., p. 246.

${ }^{395}$ YARSHELL, Flávio Luiz. Antecipação da prova sem o requisito da urgência e direito autônomo à prova. cit., p. 178. Observe-se que esse pensamento é manifestado pelo professor não obstante, em sua obra, levante dúvida quanto à existência de autênticos deveres de lealdade, cooperação e colaboração em matéria de direitos indisponíveis.

${ }^{396}$ MARINONI, Luiz Guilherme; ARENHART, Sérgio Cruz. Prova, cit., p. 156.
} 
Ferreira $^{397}$, ao defender a "máxima eficiência dos meios probatórios" como princípio fundamental da prova cível, que conduz a uma interpretação teleológica dos dispositivos referentes à produção de provas, aspecto também tratado, de forma semelhante, por Cambi ${ }^{398}$, defende a flexibilização das condutas na fase instrutória em prol da efetividade dos meios de prova.

E, nessa linha de entendimento, também entende plenamente aplicável a multa coercitiva (astreinte) na instrução probatória, a fim de estimular o cumprimento da ordem judicial, de natureza mandamental, que envolve um fazer ou a entrega de coisa (como a apresentação de determinado documento). Essa multa, por sua vez, pode ser substituída por outra medida executiva, ou mesmo cumulada com outra, indireta ou sub-rogatória (como é o caso da busca e apreensão), aplicando-se, no que cabível, o regime jurídico das tutelas específicas $^{399}$.

Marinoni e Arenhart também se manifestam pela possibilidade de aplicação de qualquer das técnicas de sub-rogação ou de coerção previstas em lei para a hipótese de descumprimento de ordem mandamental ${ }^{400}$.

E ainda, em apoio à tese por eles defendida, citam a lição do direito comparado, em especial do artigo 519 do CPC português, que, além de estabelecer o dever de colaboração para a descoberta da verdade a todas as pessoas, sejam ou não partes na causa, prevê a possibilidade de condenação em multa daquelas que se recusem a colaborar e a aplicação dos meios coercitivos possíveis (sem prejuízo da possibilidade de inversão do ônus da prova e da livre apreciação de sua recusa para efeitos probatórios).

Mas essas medidas - de sub-rogação e coercitivas - não esgotam as consequências às partes da violação do dever de colaboração na instrução processual, podendo ser aplicadas também sanções pecuniárias.

\footnotetext{
${ }^{397}$ FERREIRA, William dos Santos. Princípios fundamentais da prova cível, cit., p. 141.

${ }^{398}$ CAMBI, Eduardo. A prova civil: admissibilidade e relevância. cit.

${ }^{399}$ "Na fase instrutória surgem inúmeras ordens determinando a realização de um ato (fazer) ou a abstenção (não fazer) ou, ainda, a entrega de algo, são decisões de natureza mandamental e o seu descumprimento é ato ilícito, nada havendo que impeça o emprego da multa de natureza coercitiva prevista no artigo 461, $\$$ 4 e $5^{\circ}$ e art. 461-A, $\S 3^{\circ}$, que poderá ser fixada em montante e tempo compatíveis com a atitude que se pretende estimular." FERREIRA, William dos Santos. Princípios fundamentais da prova cível, cit., p. 154. Também nesse sentido: MEDINA, José Miguel Garcia. Execução civil: princípios fundamentais. Sao Paulo: Ed. Revista dos Tribunais, 2002. p. 441.

${ }^{400}$ Nesse sentido: "Note-se, aliás, que, a fim de viabilizar a colaboração da parte com o processo, será viável a utilização de qualquer técnica de sub-rogação - como a busca e apreensão - ou de coerção - a exemplo da multa pecuniária diária, nos moldes previstos pelo art. 461 -, tendente a obter o resultado desejado (a prova) com a colaboração da parte ou independentemente dela." MARINONI, Luiz Guilherme; ARENHART, Sérgio Cruz. Prova, cit., p. 157.
} 
Como já se tratou no Capítulo 3 supra, a violação do dever de colaboração pode caracterizar, em muitos casos, litigância de má-fé da parte, a ensejar a aplicação da multa de até $1 \%$ (um por cento) sobre o valor da causa, além da condenação nos prejuízos sofridos pela parte contrária e honorários advocatícios ${ }^{401}$.

Marinoni, inclusive, defendendo a possibilidade de aplicação cumulada da pena de litigância de má-fé com a presunção de veracidade decorrente da ausência de colaboração, assim se manifesta:

\begin{abstract}
"Conquanto a sanção da presunção seja o caminho normal em tais casos, vê-se de pronto que ela não é a única cabível. Como está claro nos arts. 17 e 18 do CPC. o litigante de má-fé pode ser condenado a pagar multa não excedente a um por cento sobre o valor da causa e indenizar a parte contrária dos prejuízos sofridos, além de honorários advocatícios e de todas as despesas que efetuou.

É importante advertir que essa sanção pode ser imposta cumulativamente ou alternativamente à presunção antes indicada. Em regra, ao lado da incidência da presunção de veracidade, cumprirá ao juiz aplicar a multa como modo de combater a litigância de má-fé." 402
\end{abstract}

Ademais, como também já anteriormente tratado, o comportamento não somente omisso da parte, mas desrespeitoso à ordem judicial, pode ensejar a imposição da multa por descumprimento do provimento mandamental, prevista no artigo 14, CPC. Isso porque, ainda que essas decisões sejam relacionadas à atividade probatória, sua inobservância é igualmente tida como ofensa à dignidade da jurisdição.

Trata-se, aqui, da contempt of court autorizadora da fixação de multa de caráter punitivo, fixada de acordo com a gravidade da conduta em montante de até $20 \%$ do valor da causa, que, se não paga no prazo estabelecido, contado do trânsito em julgado, pode ser inscrita na dívida ativa, conforme a esfera administrativa a que estiver atrelado o Poder Judiciário de que emanou a ordem descumprida. Nas palavras de Ferreira:

"Não se pode admitir que decisões corretas e proporcionais à medida instrutória que se objetiva sejam descumpridas e este 'estado de coisas' nefasto ao Estado Democrático de Direito perdure sem medidas severas.O descumprimento é muito mais do que uma quimera instrutória,

\footnotetext{
${ }^{401}$ Defendendo a possibilidade de aplicação cumulada da pena de litigância de má-fé com a presunção de veracidade decorrente da ausência de colaboração, v. MARINONI, Luiz Guilherme; ARENHART, Sérgio Cruz. Prova, cit., p. 156. Em sentido contrário, pela impossibilidade de emprego de medidas repressivas ao abuso do processo, sob o argumento de que a não observância da norma processual deve se resolver, de ordinário, pelo fenômeno da preclusão, v. RAMÓN MENDEZ, Francisco. Abuso de derecho en el processo? In: BARBOSA MOREIRA, José Carlos (Coord.). Abuso dos direitos processuais. Rio de Janeiro: Forense, 2000. p. 5.

${ }^{402}$ MARINONI, Luiz Guilherme; ARENHART, Sérgio Cruz. Prova, cit., p. 156.
} 
do que um obstáculo ao efetivo esclarecimento dos fatos relacionados a uma demanda específica: é um ato de violência à figura do Estado organizado, de um sistema que impeça a autotutela, mas que deve apresentar meios eficientes para entregar a quem detém um direito, precisamente o bem da vida que é seu, o que se passa, em uma constelação de casos, pela solução de questões fáticas" ${ }^{\text {"403 }}$.

Em nosso entender, uma vez caracterizada a litigância de má-fé ou o descumprimento da ordem mandamental, o ordenamento jurídico autoriza a imposição de sanção pecuniária prevista nos arts. 14 e 17, CPC, porquanto caracterizada a violação de um dever processual, sem prejuízo da incidência de eventual consequência processual prejudicial ao litigante, como a presunção de veracidade do fato que se pretendia provar.

\subsection{Responsabilização civil, administrativa e a função social do juiz no processo civil atual}

No que se refere ao comportamento do juiz e às consequências que lhe possam advir da falta de colaboração com as partes no processo, a matéria, além de escassamente tratada na vasta doutrina pesquisada, é permeada de inúmeras dificuldades.

Como já se tratou anteriormente, verifica-se uma tendência nos ordenamentos contemporâneos de ampliação dos poderes do juiz na direção e instrução do processo. E, como reconhece a doutrina, se a cada poder do juiz corresponde-lhe também um dever de cumpri-lo, o aumento dos poderes do juiz nesses campos deve corresponder a um aumento de sua responsabilidade, podendo o juiz ser responsabilizado por falta ou excesso no exercício dos poderes que a lei processual lhe atribui.

O tema da responsabilidade do juiz é recorrente e central na vida judiciária de um país democrático e está, também, umbilicalmente ligado à problemática da independência do juiz e à necessidade de garantir sua imparcialidade. Mostra-se, além disso, diretamente

\footnotetext{
${ }^{403}$ FERREIRA, William dos Santos. Princípios fundamentais da prova cível, cit., p. 156. Em sentido contrário, rechaçando a aplicação concomitante da multa pelo "contempto f court" em caso de recusa da parte a prestar depoimento pessoal, cf. TABOSA, Fabio Guidi. In: MARCATO, Antonio Carlos (Coord.). Código de Processo Civil interpretado, cit., p. 1096.
} 
relacionado à estrutura do ordenamento judiciário, ao funcionamento do processo e às próprias características do Estado $^{404}$.

Nesse sentido, para efeito do presente estudo, passaremos a analisar, ainda que de forma sintética, a responsabilidade civil e administrativa do juiz decorrente de atos ou omissões no exercício da função jurisdicional ${ }^{405}$.

A responsabilidade civil do magistrado guarda relação intrínseca com a própria responsabilidade do Estado perante os administrados.

No Estado Absolutista, o Estado, personificado na figura do rei, detinha poder incontrastável ante seus súditos, razão pela qual se verificava a total irresponsabilidade do Estado, refletida na máxima "the king can do no wrong". Prevalecia, àquele tempo, a chamada "teoria regalista ou regaliana", fundada na soberania estatal, na impossibilidade de o Estado figurar como violador de direitos e na impropriedade de assumir a responsabilidade de atos praticados por seus funcionários, que deveriam assumi-los pessoalmente ${ }^{406}$.

A partir da Revolução Francesa e com o advento do Estado Moderno e, ainda, do Estado social, concebido a partir do primado da liberdade e contendo a previsão de uma gama de garantias ao cidadão, passou-se a admitir entre essas garantias a reparabilidade pelos danos causados em razão de ação ou omissão do Estado ${ }^{407}$. Da fase da irresponsabilidade do Estado passou-se, então, a uma segunda fase, de responsabilidade, representada inicialmente pela chamada "teoria civilista", fundada que era nos princípios de direito civil apoiados na ideia de culpa.

A teoria civilista fazia distinção entre atos de império e atos de gestão, sendo que os primeiros escapariam ao controle jurisdicional ainda que danosos aos particulares, ao passo nos outros se admitia a responsabilização, colocando-se a administração e o administrado no mesmo plano. Contudo, a dificuldade de tipificação dos atos de império e de gestão levou ao surgimento das teorias publicistas, com destaque, nesse aspecto, para o relevante papel assumido pela jurisprudência francesa.

\footnotetext{
${ }^{404}$ CARPI, Federico. A responsabilidade do juiz. Revista de Processo, Sao Paulo, v.20, n. 78, p. 123-132, abr./jun. 1995.

${ }^{405}$ Não se ignora a possibilidade de responsabilização penal do juiz, matéria essa, no entanto, que por transbordar os limites do presente estudo, deixará de ser abordada.

${ }^{406}$ LOUREIRO FILHO, Lair da Silva. Responsabilidade pública por atividade judiciária. São Paulo: Ed. Revista dos Tribunais, 2005. p. 48.

${ }^{407}$ WAMBIER, Luiz Rodrigues. A responsabilidade civil do Estado decorrente dos atos jurisdicionais. Revista dos Tribunais, Sao Paulo, v. 77, n. 633, p. 34-42, jul. 1988.
} 
Surgiram, então, diversas teorias publicistas até culminar com a admissão da responsabilidade objetiva, fundada na simples relação de causalidade entre o comportamento administrativo e o evento danoso ${ }^{408}$.

A doutrina destaca, no entanto, que a teoria da irresponsabilidade nunca foi aceita pela doutrina e jurisprudência nacional, mesmo à mingua de disposição legal específica a esse respeito. Assim, a responsabilidade do Estado por ato de seus agentes era reconhecida pela jurisprudência, no Brasil, deste o início da República, tal como sucedia no exterior.

Atualmente, Constituição Federal prevê expressamente a responsabilidade objetiva do Estado danos que seus agentes, nessa qualidade, causarem a terceiros (art. 37, § $\left.6^{\circ}\right)^{409}$. No que se refere especificamente aos atos jurisdicionais, a Constituição Federal atual prevê a responsabilidade do Estado de indenizar o condenado por erro judiciário, assim como pela prisão além do tempo fixado na sentença (art. $\left.5^{\circ}, \mathrm{LXXV}\right)$.

Não há, todavia, consenso doutrinário, nem jurisprudencial, quanto à responsabilização civil do Estado por atos jurisdicionais, afora os casos expressamente previstos na Constituição Federal (condenação criminal ou prisão indevida). Com efeito, costuma-se levantar como óbices à responsabilidade estatal por atos jurisdicionais: a soberania do Estado, a independência funcional dos juízes, o fato de o juiz não ser funcionário público e o efeito preclusivo da coisa julgada ${ }^{410}$.

São diversos os precedentes do Supremo Tribunal Federal refutando a responsabilidade do Estado por atos jurisdicionais e afastanto, notadamente, a aplicação da teoria da responsabilidade objetiva, dadas as características peculiares dessa expressão do poder estatal, salvo nas hipóteses expressamente previstas em lei ${ }^{411}$.

\footnotetext{
${ }^{408}$ SILVA FILHO, Artur Marques da. Juizes irresponsaveis?: uma indagacao sempre presente. Revista dos Tribunais, São Paulo, v. 80, n. 674, p. 70-80, dez. 1991.

${ }^{409}$ A responsabilidade objetiva do Estado, aliás, passou a ser expressamente reconhecida no Brasil a partir da Constituição de 1946 (art. 194), que previa a ação regressiva contra o agente que agiu com dolo ou culpa, o que foi mantido pelos demais textos constitucionais até a Constituição Federal atual.

${ }^{410}$ Maria Sylvia Zanella de Pietro, após rebater um a um desses argumentos, observa que: “As garantias de que se cerca a magistratura no direito brasileiro, previstas para assegurar a independência do Poder Judiciário, em benefício da justiça, produziram a falsa ideia de intangibilidade, inacessibilidade e infalibilidade do magistrado, não reconhecida aos demais agentes públicos, gerando efeito oposto de liberar o Estado de responsabilidade pelos danos injustos causados àqueles que procuram o Poder Judiciário justamente para que justiça seja feita.” DI PIETRO, Maria Sylvia. Direito administrativo. 25. ed. São Paulo: Atlas, 2012. p. 719.

${ }^{411}$ É o que se colhe dos seguintes julgados: STF, 1a t., RE 219.117-4-PR, rel. Min.Ilmar Galvão, j. 03.08.1999, por unanimidade, DJ 29.10.1999, STF 2 a t., Ag. Reg. no RE 429.518-1-SC, rel. Carlos Velloso, j. 05.10.2004, por unanimidade, DJ 28.10.2004 e STF, $2^{\mathrm{a}}$ t., Emb. Decl. no RE 553.637-8, rel. Ellen Gracie, j.04.08.2009, por unanimidade, DJ 24.09.2009.
} 
No que se refere à responsabilidade pessoal e direta do magistrado, a matéria é ainda mais controvertida, sendo forte a tendência de não admiti-la ou mesmo de reduzir ao máximo seu espectro de aplicação ${ }^{412}$.

Cappelletti $^{413}$, defendendo a responsabilização direta do Estado, com direito de regresso deste em face do magistrado (caso preenchidos os pressupostos de sua responsabilidade), entende que esse sistema garante, por um lado, o efetivo ressarcimento do prejudicado e, ao mesmo tempo, preserva o juiz de pressões que possam afetar sua independência e imparcialidade. E, rebatendo a possibilidade de responsabilidade direta do juiz, levanta os seguintes argumentos: exposição do juiz à pressão indevida das partes, com demandas propostas com mero espírito de vingança; desnecessidade da responsabilização direta, já que o Estado sempre é responsável e tem condições econômicas mais favoráveis ao adimplemento; e desnecessidade de produzir prova do elemento subjetivo, quando o Estado responde independentemente de culpa.

De se registrar, aliás, que esse é justamente o sistema adotado pelo ordenamento jurídico italiano (Lei 117/88) ${ }^{414}$, embora tramite recente proposta de lei disciplinando a modificação desse sistema, como se verá adiante. Diversamente, o ordenamento jurídico espanhol admite a responsabilidade concorrente do Estado e do juiz. ${ }^{415}$

No Brasil, a matéria é tratada, além de diretamente na Constituição Federal, em diversos dispositivos infraconstitucionais, e, no tocante ao processo civil, especificamente nos artigos 43 do CC, 133 do CPC e 129 da Lei Orgânica da Magistratura (LOMAN - Lei Complementar 35/79).

O CPC e a LOMAN estabelecem a responsabilidade civil do juiz por perdas e danos nas hipóteses em que, no exercício de suas funções, proceder com dolo ou fraude (ato comissivo), ou ainda recusar, omitir ou retardar, sem justo motivo, providência que deva ordenar de ofício ou a requerimento da parte (ato omissivo). Neste último caso, a lei

\footnotetext{
${ }^{412}$ Nesse sentido: STF: $2^{\text {a }}$ t., RE 228.977-2-SP, rel. Neri da Silveira, j. 05.03.2002, por unanimidade, DJ 12.04.2002, STF.

${ }^{413}$ CAPPELLETTI, Mauro. Juízes irresponsáveis? Trad. Carlos Alberto Alvaro de Oliveira. Porto Alegre: SAFE, 1989.

${ }^{414}$ Art. $2^{\circ}$ "quem sofreu um dano injusto em virtude de comportamento, ato ou pronunciamento judicial realizado pelo magistrado com dolo ou culpa grave no exercício de suas funções, ou por denegação de justiça, pode acionar o Estado para obter o ressarcimento dos danos patrimoniais e também dos não patrimoniais e também dos não patrimoniais que decorram da privação da liberdade pessoal". (tradução livre).

${ }^{415}$ Cf. CARPI, Federico. A responsabilidade do juiz, cit., p. 129-132.
} 
ainda exige que haja prévia intimação do juiz, por intermédio do escrivão, para praticar o ato que lhe cabe em $10(\mathrm{dez}) \mathrm{dias}^{416}$.

Parcela considerável da doutrina entende que a importância da previsão legal está, justamente, em afastar a responsabilização civil do juiz da responsabilidade aquiliana, ou seja, afirmar que o juiz realmente só responde nessas duas hipóteses e, ainda, assim, na via regressiva, aqui por interpretação do texto constitucional (art. $37, \S 6^{\circ}, \mathrm{CF}$ ).

Laspro, em tese de doutorado dedicada ao tema, defendeu posição absolutamente contrária a essa interpretação, destacando como finalidades da responsabilização civil direta do juiz: a obtenção, pelo prejudicado, da justa reparação, servindo ainda como meio de fornecimento de informações para o exercício da responsabilidade disciplinar e até mesmo penal (escopo reparador); a imposição ao juiz de uma espécie de pressão psicológica diante do temor de, eventualmente, vir a ser demandado e ter de ressarcir a vítima de sua atividade jurisdicional (escopo preventivo-punitivo); e, ainda, a primazia da magistratura profissional sobre a burocrática e laica, com a exigência de atualização profissional e preparo intelectual compatível com a relevância da atividade jurisdicional, o que deve persistir durante toda a carreira do magistrado (escopo ideológico) ${ }^{417}$.

O autor critica a tendência de colocar o Estado como verdadeiro escudo-protetor do juiz, defendendo, ainda que de lege ferenda, a possibilidade de a parte demandar simultaneamente em face do Estado e do juiz, desde que verificada ao menos a culpa do magistrado. O professor destaca que a norma constitucional que prevê a responsabilidade objetiva do Estado com direito de regresso em face do agente (aplicável, a seu ver, aos atos jurisdicionais), foi estabelecida em benefício do administrado, de molde a facilitar a reparação de danos, não podendo ser interpretada como restrição ao seu direito.

Nesse sentido, tratando-se de erro judiciário (ato comissivo), sustenta a responsabilidade direta do juiz (em litisconsórcio ou não com o Estado) nos casos de dolo ou fraude (ou seja, quando caracterizada a intenção de beneficiar ou prejudicar alguém), além de sua responsabilidade subsidiária em caso de culpa (responsabilidade objetiva do

\footnotetext{
${ }^{416} \mathrm{~A}$ respeito da necessidade de prévia interpelação do juiz, Oreste Nestor de Souza Laspro faz acentuada crítica: "trata-se de norma visando efetivamente obstaculizar qualquer tentativa de responsabilizar o juiz por sua omissão, isto é, a única hipótese expressa na legislação infra constitucional de responsabilidade direta do juiz por culpa é inviabilizada, na prática, pelo parágrafo do mesmo artigo." in LASPRO, Oreste Nestor de Souza. A responsabilidade civil do juiz. São Paulo: Ed. Revista dos Tribunais, 2000.

${ }^{417} \mathrm{E}$ completa: "Do magistrado profissional deve ser exigido o mesmo grau de eficiência que encontramos em qualquer outra atividade, ainda que, como em todos os casos, devam ser levadas em consideração as respectivas particularidades.", in LASPRO, Oreste Nestor de Souza. A responsabilidade civil do juiz, cit., p. 163.
} 
Estado, com possibilidade de regresso contra o magistrado fundado na responsabilidade aquiliana). Por outro lado, tratando-se de anormal funcionamento da jurisdição (ato omissivo), defende que o juiz, tal como o Estado, somente responde com culpa pela conduta omissiva $^{418}$.

A matéria, todavia, está longe de ser pacífica, suscitando ainda acaloradas discussões no âmbito doutrinário e jurisprudencial ${ }^{419}$.

E, a comprovar o que afirma, cite-se o artigo jurídico recentemente publicado por Yarshell posicionando-se de modo radicalmente contrário ao projeto de lei que tramita na Itália e que estabelece a responsabilidade civil direta do juiz por erro de julgamento, fazendo um paralelo com o atual cenário da justiça brasileira ${ }^{420}$.

Alerta o autor, primeiramente, para a dificuldade da definição do que seja erro judicial, pois, afora os casos específicos tratados no art. 133, CPC, o exame dos fatos e seu enquadramento ao direito são indissociáveis da liberdade de julgar. Além disso, segundo o professor, para esse tipo de correção existe o sistema recursal e, no limite, a ação rescisória, formas legítimas de controle das decisões judiciais, o que é preferível à responsabilização civil do juiz, que põe em risco a independência dos magistrados, ressaltando que "poucas coisas são tão essenciais ao exercício da judicatura quanto essa autonomia”. Pondera, ainda, para a inoportunidade dessa discussão no atual cenário da Justiça brasileira, dada considerável pressão social que já recai sobre os juízes, na atualidade, para que aumentem a produtividade e alcancem determinadas metas, o que invariavelmente acaba por comprometer a qualidade das decisões.

Yarshell chama a atenção, ainda, para o fato de que as dicussões travadas em torno dos problemas da prestação jurisdicional têm levado os operadores do direito a imputaremse, mutuamente, a responsabilidade pelas mazelas, todos, porém, sem razão. Justamente

\footnotetext{
${ }^{418}$ Sidnei Amendoeira Jr. endossa a crítica às restrições quanto à responsabilidade pessoal do magistrado: "No nosso modo de entender, nada justifica a letra da lei que responsabiliza o Estado e 'esconde' o magistrado que só pode ser responsabilizado naquelas hipóteses específicas acima mencionadas. Esse sistema é absolutamente anacrônico, já que irá premiar certamente os juízes menos diligentes e zelosos de suas funções que, por vezes, e sabemos que esta não é a regra, cometem uma série de desatinos no curso do processo e nenhuma responsabilidade pode ser-lhes imposta." (AMENDOEIRA JUNIOR, Sidnei. Poderes do juiz e tutela jurisdicional: a utilização racional dos poderes do juiz como forma de obtenção da tutela jurisdicional efetiva, justa e tempestiva, cit., p. 90).

${ }^{419}$ Sustentando a inconstitucionalidade das normas que prevêem a responsabilização direta do juiz, v. ARAÚJO, Edmir Netto de. Responsabilidade do Estado por ato jurisdicional. São Paulo: Ed. Revista dos Tribunais, 1981. Contrariamente, entendendo que as normas do CPC e da LOMAN conduzem à responsabilidade direta e pessoal do juiz, nos casos nela previstos, excluindo a responsabilidade estatal, v. RODRIGUES, Silvio. Direito civil. 20. ed. rev. e atual. São Paulo: Saraiva, 2003. v. 4, p. 87-88.

${ }^{420}$ YARSHELL, Flávio Luiz. Responsabilidade civil do juiz por erro judicial: uma proposta equivocada. Carta Forense, São Paulo, maio 2012. p. A4.
} 
nesse contexto é que se tem pretendido, por um lado, sancionar pessoalmente os advogados por litigância de má-fé em casos, por exemplo, de "excesso de recursos" e, por outro, recrudescer a responsabilidade civil do juiz por erro judicial ou morosidade no julgamento, o que, além de não atacar o problema, coloca em risco o adequado funcionamento do sistema jurisdicional. Em seu entender, os esforços devem ser canalizados, diversamente, em torno da melhoria da estrutura pessoal e material do Judiciário e racionalização da atividade.

Por fim, o professor lembra que o sistema brasileiro já detém, fora do âmbito estritamente jurisdicional, mecanismos adequados de controle administrativo e disciplinar dos juízes ${ }^{421}$, o que se passará a tratar a seguir.

A responsabilidade administrativa ou disciplinar do juiz, diferentemente da responsabilização civil, não tem por objetivo o ressarcimento de eventuais danos causados no exercício da atividade, mas sim a punição da conduta indevida do juiz, violadora dos deveres inerentes ao cargo do magistrado ou incompatível com a dignidade da atividade jurisdicional.

Além disso, a responsabilização administrativa ou disciplinar não tem por escopo a reforma do ato jurisdicional. Assim, o erro na interpretação da lei e a valoração equivocada de fatos e provas, em regra, não enseja controle disciplinar, mas apenas jurisdicional, obtido através de recursos e ações próprias. Do contrário, poderia ser transformada em instrumento de violação da independência do juiz e do princípio do livre convencimento motivado $^{422}$.

Segundo o entendimento de $\mathrm{Carpi}^{423}$, o tema da responsabilidade disciplinar apresenta vínculos indissociáveis com o sistema de recrutamento, formação e desenvolvimento da carreira do magistrado. Assim, para ele, esse tipo de responsabilidade vem assumindo importância cada vez maior em países que empregam métodos inadequados no sistema de ingresso na carreira da magistratura.

O autor cita problemas verificados frequentemente na Itália e que acabam refletindo no aumentando da importância da responsabilidade disciplinar do magistrado: a formação

\footnotetext{
${ }^{421}$ E completa: "Pretender incrementá-los pela ameaça de condenação seria equívoco crasso que, no médio prazo, traria malefícios para o próprio jurisdicionado, pelo enfraqueciomento de uma instituição sem a qual não há Democracia." In YARSHELL, Flávio Luiz. Responsabilidade civil do juiz por erro judicial: uma proposta equivocada, cit., p. A4.

${ }^{422}$ LASPRO, Oreste Nestor de Souza. A responsabilidade civil do juiz, cit., p. 154-161.

${ }^{423}$ Cf. CARPI, Federico. A responsabilidade do juiz, cit., p. 129-132.
} 
profissional do juiz apresenta lacunas e não é submetida a avaliações posteriores à entrada na carreira.

No Brasil, em nosso entender, o problema se repete, já que não se tem qualquer tipo de avaliação de conhecimento posterior ao ingresso na carreira da magistratura, o que serviria de importante ferramenta para a imposição de constante atualização profissional do magistrado. Acresce, ainda, que a exigência de comprovação de atividade jurídica anterior, seja em razão do curto perído exigido (apenas 3 anos), seja por seus frágeis critérios de aferição, não tem sido capaz, na prática, de assegurar a maturidade profissional necessária para o empenho de tão relevante função.

O controle disciplinar dos juízes é feito historicamente no Brasil pelas corregedorias dos próprios Tribunais, com base na Lei Orgânica da Magistratura Nacional - LOMAN (que prevê deveres aos magistrados e penalidades em caso de infringência) e nos regimentos internos. A corregedoria é orgão interno que exerce o controle dos magistrados (atividade correicional) e é dirigida por um corregedor-geral, eleito, por voto do plenário, entre os juízes mais antigos, para o exercício de um mandato de dois anos.

A partir da Emenda Constitucional no 45/2004, no entanto, foi criado o Conselho Nacional de Justiça, com atribuição, dentre outras ${ }^{424}$, de exercer o "controle do cumprimento dos deveres funcionais dos juízes”.

No âmbito das atribuições do Conselho Nacional de Justiça cabe-lhe "receber $e$ conhecer de reclamações contra membros ou órgãos do Poder Judiciário (...) sem prejuízo da competência disciplinar e correicional dos tribunais", podendo "avocar processos disciplinares em curso" nos Tribunais e até mesmo "rever, de ofício ou mediante provocação, os processos disciplinares de juízes e membros dos tribunais julgados há menos de um ano ${ }^{425}$ (art. 103-B, § $4^{\circ}$, III e V, CF).

Tais atividades podem ser desencadeadas de ofício ou por reclamação disciplinar de qualquer interessado. E, dentre as sanções administrativas passíveis de serem impostas ao magistrado, uma vez comprovada a violação ao seu dever funcional, estão a remoção, a disponibilidade e a aposentadoria compulsória.

\footnotetext{
${ }^{424}$ Além da função disciplinar, detém o Conselho Nacional de Justiça também funções regulamentares e fiscalizatórias.

${ }^{425}$ De acordo com o artigo 83 do Regimento Interno do Conselho Nacional de Justiça, a revisão disciplinar é possível em casos de decisão contrária a texto expresso de lei, quando comprovada a falsidade dos depoimentos, exames ou documentos em que fundada a decisão, e, ainda, quando, após a decisão, surgirem documentos novos que autorizem a modificação da decisão.
} 
O Conselho é composto, além de membros do próprio Poder Judiciário, por representante do Ministério Público da União e dos Estados, dois advogados indicados pela OAB e dois cidadãos de notável saber jurídico e reputação ilibada, indicados um pela Câmara e outro pelo Senado Federal, todos com mandato de dois anos. Em que pese sua composição híbrida, o Conselho Nacional de Justiça, por expressa disposição constitucional (art. 92, I, A), é reconhecido como orgão do Poder Judiciário ${ }^{426}$.

Afora as acaloradas discussões, ainda atuais, sobre a competência disciplinar concorrente e autônoma ou meramente subsidiária e complementar do Conselho Nacional de Justiça ${ }^{427}$, fato é que ambos os órgãos (corregedorias dos Tribunais e CNJ) são responsáveis, atualmente, por promover a apuração e a responsabilização disciplinar dos juízes quando constatada a violação de seus deveres funcionais.

Do que se expôs até o momento, o que se verifica é que o ordenamento jurídico brasileiro, se de um lado impõe regras de conduta ético-jurídicas também ao magistrado, na qualidade de diretor do processo, autoriza, em regra geral, sua responsabilização civil e administrativa (e até mesmo penal) em casos de infringência aos seus deveres funcionais, notadamente quando causadores de danos aos jurisdicionados, embora com algumas resistências já anteriormente citadas, o que parece se aproximar do modelo de “responsabilização social” concebido por Cappelletti ${ }^{428}$.

Com efeito, em estudo comparativo entre os sistemas de responsabilidade judicial adotados em diversos países analisados, Cappelletti identificou uma tendência evolutiva das sociedades modernas, no sentido de combinar a responsabilidade política e social com a responsabilidade jurídica dos magistrados, evitando, de um lado, a subordinação dos juízes a poderes políticos ou mesmo a ações abusivas e intimidatórias dos litigantes, o que poderia afetar a necessária independência para o desenvolvimento da atividade jurisdicional, e, de outro, afastando o risco do isolamento corporativo da magistratura, com a consequente anarquia e irresponsabilidade dos seus membros. Esse modelo, segundo Cappelletti, reflete a ideia central de todos os sistemas democráticos de governo, traduzido

\footnotetext{
${ }^{426}$ Esse, aliás, é um dos principais fundamentos da rejeição da ADI 3367/DF, proposta pela Associação dos Magistrados Brasileitos, que fundamentava a inconstitucionalidade da criação do CNJ na independência dos poderes (cláusula pétrea da $\mathrm{CF}$ ), no sistema federativo e consequente autonomia administrativa e financeira dos Tribunais.

${ }^{427}$ A respeito de toda a discussão jurídica travada sobre a constitucionalidade da criação do Conselho Nacional de Justiça, v. RULLI NETO, Antonio. Controle externo do Poder Judiciário no Brasil. 2007. Tese (Doutorado) - Faculdade de Direito, Universidade de São Paulo, 2007.

${ }^{428}$ CAPPELLETTI, Mauro. Juízes irresponsáveis? Trad. Carlos Alberto Alvaro de Oliveira. Porto Alegre: SAFE, 1989.
} 
pela conhecida fórmula de "checks and balances", ou seja, lastreado na ideia de controle dos poderes do Estado, que não são ilimitados e nem podem ser exercidos irresponsavelmente. ${ }^{429}$

A questão que resta analisar, no entanto, é quais seriam as consequências da inobservância do dever de colaboração imposto ao juiz no processo, notadamente na instrução processual. Seria possível pensar em responsabilização civil e administrativa nessas hipóteses?

A dificuldade em responder a essa indagação só aumenta quando se considera que a atividade instrutória e todas as relevantes e intrincadas questões dela decorrentes estão intimamente ligadas ao convencimento judicial, resguardadas, portanto, pelos princípios da persuasão racional e do livre convencimento motivado. Daí porque, afora a possibilidade de impugnação das decisões no mérito, por meio dos recursos cabíveis, se afigura difícil, ao menos à primeira vista, imaginar que uma tal conduta do juiz -notadamente sua omissão - possa ensejar responsabilização nas esferas civil e administrativa, sem que isso constitua afronta à liberdade de convencimento do juiz e, em última análise, à independência e autonomia da magistratura.

Não há dúvida que em algumas situações específicas, o panorama se modifica. É o que ocorre, por exemplo, quando constatado o dolo do magistrado. No âmbito da atividade instrutória, Laspro ${ }^{430}$ cita interessante exemplo de conduta dolosa, consistente na hipótese de sugestão, em que o juiz, ao ter conhecimento dos fatos, forma prematuramente sua convicção e, a partir de então, passa a conduzir o processo com a finalidade de alcançar o resultado que preconcebeu, manipulando-o àquele fim. Assim, em razão dessa convicção preconcebida, indefere provas necessárias ao esclarecimento dos fatos, distorce o depoimento das partes, direciona a resposta das testemunhas, altera sua versão ao transcrevê-las na ata ou, ainda, influencia, com sua convicção antecipada, o resultado da prova pericial, etc. Em casos tais, demonstrável, através de provas e elementos racionais, o verdadeiro dolo do magistrado por seus atos e omissões no processo, acreditamos ser

\footnotetext{
429 “A responsabilidade judicial deve ser vista não em função do prestígio ou independência da magistratura enquanto tal, nem em função do poder de uma entidade abstrata como o 'Estado' ou 'o soberano', seja este indivíduo ou coletividade. Ela deve ser vista, ao contrário, em função dos usuários e, assim, como elemento de um sistema de justiça que conjugue a imparcialidade - e aquele tanto de separação ou isolamento político e social que é exigido pela imparcialidade - com razoável grau de abertura e de sensibilidade à sociedade e aos indivíduos que a compõem, a cujo serviço exclusivo deve agir o sistema judiciário." (CAPPELLETTI, Mauro. Juízes irresponsáveis?, cit., p. 91).

${ }^{430}$ LASPRO, Oreste Nestor de Souza. A responsabilidade civil do juiz, cit., p. 236.
} 
realmente possível a responsabilização do juiz no âmbito civil e disciplinar. Esse, aliás, é o mesmo exemplo de parcialidade na instrução processual citado por Ferreira:

"Pode haver parcialidade do juiz durante a instrução, passível de suspeição, mas não será extraída singelamente de sua postura ativa, mas sim de uma postura direcionista em relação a fatos determinados, são exemplos: a pressão e insistência durante o depoimento de uma testemunha, mesmo quando esta insista em reiterar o fato que declarou, $o$ direcionamento das perguntas sempre em um sentido específico, perguntas narrativas aguardando, exclusivamente, respostas monossilábicas (sim ou não). ${ }^{, 31}$

Outro exemplo que nos ocorre, porém de mais difícil aplicação, consiste na hipótese, bastante comum no cotidiano forense, de o indeferimento de provas e o julgamento antecipado da lide, posteriormente anulado pela instância superior, ante o reconhecimento do cerceamento de defesa (já que não subsumível a qualquer das hipóteses do art. 330), causar dano a uma das partes pelo prolongamento indevido do feito. A questão aqui nos parece de mais difícil configuração porque, não estando presente o elemento doloso, sempre terá o magistrado a "defesa" de que agiu de acordo com seu livre convencimento, devidamente motivado e que eventual reforma da decisão não tem o condão de gerar responsabilização.

Uma terceira situação, talvez esta sim mais adequada como exemplo do que aqui dizemos, consiste no caso de, mesmo se tratando de controvérsia fática, o juiz decidir julgar antecipadamente a lide aplicando simplesmente a regra do ônus da prova, sem determinar a prévia abertura da instrução processual, ainda que expressamente requerida pela parte posteriormente prejudicada ${ }^{432}$. Nesse caso, que nos parece exemplo claro exemplo de error in procedendo, anulada posteriormente a decisão pela instância superior e constatados danos à parte pelo prolongamento indevido do processo, parece-nos, ao menos em tese, possível a reponsabilização do juiz no âmbito civil e administrativo. Nesse sentido, já se manifestou Barbosa Moreira:

\footnotetext{
${ }^{431}$ FERREIRA, William dos Santos. Princípios fundamentais da prova cível, cit., p. 204.

${ }^{432}$ William dos Santos Ferreira entende que mesmo não requerida a produção de prova por uma das partes, não pode o juiz julgar antecipadamente com base na regra do ônus da prova, devendo determinar as provas de ofício. Nesse sentido: "Pelo que se identifica nos dispositivos legais, o juiz, se não estiver convencido (art. 131), deve determinar a realização das provas que entenda necessárias ao esclarecimento (art. 130), porque, do contrário, mesmo que uma parte não requeira a produção de prova, não poderia o juiz julgar antecipadamente a lide com aplicação do 'ônus da prova' por exemplo. (...) se há uma inércia da parte, isoladamente, sem importar em confissão ou presunção de veracidade dos fatos alegados pelo autor, das duas uma: ou haverá convicção judicial (art. 131 c/c art. 330) ou deve ser determinada pelo juiz a dilação probatória (art. 130).” FERREIRA, William dos Santos. Princípios fundamentais da prova cível, cit., p. 206.
} 
"É difícil, por exemplo, continuarmos a aceitar com tranquilidade que, anulado um processo em razão de grave error in procedendo, não se obrigue o juiz que o cometeu a ressarcir os danos porventura causados pelo indevido prolongamento do feito." 433

Afora tais situações, no entanto, não nos parece que seja defensável uma tal possibilidade, ao menos assim genérica, de responsabilidade do juiz quando verificada a falta de colaboração na instrução processual, nem mesmo naquelas hipóteses que arrolamos como manifestações do dever de colaboração do juiz na instrução processual (fixação dos pontos controvertidos, prévia intimação sobre a decisão de inversão do ônus da prova, impossibilidade de valoração antecipada de seu resultado, submissão de toda e qualquer prova ao crivo das partes, etc.).

Ou seja, salvo situações particularizadas (ou melhor, verdadeiramente patológicas) que justifiquem tratamento diverso (tal como os exemplos de que tratamos anteriormente), na rigorosa maioria dos casos a falta de colaboração do juiz e suas consequências processualmente danosas às partes deverão ser questionadas pelos meios de impugnação previstos no ordenamento.

A nosso ver, a questão está relacionada, portanto, mais à necessidade de conscientização do juiz atual sobre a relevante função social que desempenha no processo, os objetivos públicos por ele perseguidos e à exigência de uma nova postura que se amolde à feição do Estado contemporâneo de Direito, do que à ameaça de imposição de sanções ao magistrado.

De fato, a atuação do juiz na ordem atual e o aumento de seus poderes, como reflexo da realidade social de seu tempo, exige-lhe uma postura ativa, participativa e comprometida com o resultado da atividade jurisdicional, o que se revela tanto na interpretação das normas e aplicação do direito como também na condução do processo enquanto instrumento ${ }^{434}$.

Nesse sentido, sem que se possa prescindir dos instrumentos de prevenção e repressão de eventuais desvios dos deveres funcionais do juiz, ou seja, para atacar as

\footnotetext{
${ }^{433}$ BARBOSA MOREIRA, José Carlos. Os novos rumos do processo civil brasileiro, cit., p. 140.

434، o juiz contemporâneo não tem mais como se manter neutro e indiferente, distante do calor dos acontecimentos, acomodado ao frio mister de singelo aplicador das normas aos fatos, até porque a complexidade da vida social, associada à velocidade dos acontecimentos não raro atropelam as ocorrências positivadas, fazendo a cada passo emergir situações de verdadeira aporia, onde não se encontra a norma que deveria regular o caso concreto, levando a que, não raro, tenha o juiz que preencher, com prudência e sensibilidade, os conceitos vagos e indeterminados, cada vez mais emergentes no Direito brasileiro." (BARBOSA MOREIRA, José Carlos. Os novos rumos do processo civil brasileiro, cit., p. 140).
} 
patologias, esse comprometimento e a consciência de sua função social se dão mais no plano da formação e da educação do que propriamente no de medidas repressivas. Nesse sentido é o pensamento de Carpi:

"Os males da justiça em nossos países não se resolvem no plano da responsabilidade do juiz, mas por meio de uma organização mais funcional do trabalho - conseguível com legislações processuais modernas, mas não apenas com elas - e de maior esforço por parte dos operadores da Justiça, juízes e advogados, a serviço do cidadão, para o exercício não de um poder, mas de uma função social, a mais nobre. (...) A importância máxima cabe à formação dos homens, ainda mais importante que as boas reformas legislativas.. ${ }^{, 435}$

E, para finalizar, citamos trecho da obra de Calamandrei que, com sua conhecida maestria, consegue bem descrever o que aqui, ao final do capítulo, se tentou demonstrar:

"Não é a corrupção que pode constituir um perigo para os magistrados. Os casos de corrupção por dinheiro que vi em cinquenta anos de experiência podem ser contados nos dedos de uma só mão; e sempre os vi serem descobertos e punidos exemplarmente. Também não se deve considerar ameaças muito graves à independência dos magistrados as interferências políticas: elas são frequentes, mas não irresistíveis. $\mathrm{O}$ magistrado reto não as leva a sério, e é raríssimo que esta sua inflexibilidade the provoque algum dano.

O verdadeiro perigo não vem de fora: é um lento esgotamento interno das consciências, que as torna aquiescentes e resignadas; uma crescente preguiça moral, que à solução justa prefere cada vez mais a acomodadora, porque não perturba o sossego e porque a intransigência requer demasiada energia.

$\mathrm{Na}$ minha longa carreira, nunca me encontrei face a face com juízes corruptos, mas conheci muitos juízes indolentes, desatentos, carentes de vontade, prontos a se deter na superfície, para fugir do duro trabalho de escavação, que quem deseja descobrir a verdade tem que enfrentar."

${ }^{435}$ CARPI, Federico. A responsabilidade do juiz, cit., p. 132.

${ }^{436}$ CALAMANDREI, Piero. Eles, os juízes, vistos por um advogado, cit., p. 277-278. 


\section{CONCLUSÃO}

O presente estudo teve por objetivo investigar a influência da instrumentalidade, do viés publicista, do conteúdo ético e das demais premissas metodológicas do processo civil atual na conduta do juiz e das partes no curso da instrução probatória, de modo a identificar, nesse contexto, a existência de autênticos deveres das partes e do juiz em matéria de prova e as consequências jurídicas de sua inobservância.

As principais conclusões obtidas ao longo de todo o estudo podem ser sintetizadas nas seguintes afirmações:

1. O direito não é infenso aos valores sociais e às determinantes históricas, políticas e culturais da sociedade na qual se insere. O processo civil, por consequência, também não é ciência neutra às opções axiológicas do Estado e da sociedade, razão pela qual experimentou, ao longo dos anos, diversos momentos metodológicos, reconhecidos pela doutrina como fases sincretista, autonomista e instrumentalista.

2. Na fase denominada instrumentalista, a ciência processual civil, abandonando a visão puramente técnica que marcou a fase autonomista, passou a voltar sua atenção ao caráter instrumental do processo e à necessidade de assegurar o alcance de seus fins, ou seja, a realização do direito material. Além disso, a perspectiva constitucional do processo, objeto de atenção dos estudiosos nas últimas décadas, veio a contribuir para afastar, de forma definitiva, o processo do plano das construções conceituais e meramente técnicas e inseri-lo na realidade política e social do país.

3. A evolução dos estudos do processo também abriu espaço para o progresso da perspectiva publicista do direito processual, hoje tida como tendência universal, com o reconhecimento do interesse não apenas das partes envolvidas, mas do próprio Estado na consecução das finalidades do processo, na medida em que este constitui ferramenta, de natureza pública, para a realização da justiça e obtenção da paz social.

4. E, no caso brasileiro, a visão publicista do processo é ainda mais justificada pelo modelo de Estado e as opções políticas por ele adotadas, pois o Estado brasileiro, contrapondo-se à ideia do liberalismo e absenteísmo estatal, adotou o modelo de um Estado Social e Democrático de Direito, tendo assumido, na linha das Constituições 
modernas, a postura de agente do desenvolvimento e da justiça social, garantindo direitos individuais e sociais aos indivíduos e propiciando-lhes prestações estatais positivas.

5. Essa tendência publicista, por sua vez, tem levado a uma reflexão sobre o papel exercido pelo Estado-Juiz, com o reforço de seus poderes diretivos e instrutórios no processo, assim como sobre o papel das partes, cuja participação no processo constitui elemento revelador do próprio caráter democrático do Estado.

6. Nesse contexto, recente doutrina processual brasileira chega a afirmar a vigência, nos dias atuais, de uma quarta fase metodológica da ciência processual, fundada no marco teórico do "formalismo-valorativo" e correspondente a um modelo de processo pautado pelo permanente diálogo judiciário, colaboração e lealdade entre as pessoas que dele participam.

7. O denominado "formalismo-valorativo" encerra a ideia de um justo equilíbrio entre as posições jurídicas do autor, do juiz e do réu no processo, em consonância com uma posição mais interessada, participativa e menos autoritária e formalista do juiz no processo. Essas ideias, por sua vez, constituem a base teórica do denominado "processo civil cooperativo", orientado predominantemente pelos valores justiça, participação leal, segurança e efetividade.

8. Independentemente de se tratar ou não de um "novo" momento metodológico, essa atual concepção do processo civil, fruto do desenvolvimento das ideias publicista e instrumentalista do processo, traz reflexos profundos na postura do juiz e das partes em todo o iter procedimental, e notadamente na fase instrutória do processo, o que constituiu objeto central de nosso estudo.

9. Com efeito, os tradicionais conceitos colhidos na doutrina trazem ínsita a ideia de que a prova se destina à formação do convencimento do julgador, sendo este, portanto, seu destinatário principal, direto e natural, o que decorre, aliás, dos princípios da persuasão racional e do livre convencimento motivado. No entanto, no paradigma atual da ciência processual, entende-se que as partes também são destinatárias da prova produzida no processo, à medida que não somente têm interesse no seu resultado, como este pode (e deve) conduzir sua conduta dentro e fora do processo.

10. Além disso, a caracterização da prova como simples ônus da parte (entendido como imperativo do próprio interesse, faculdade cuja inobservância somente pode 
acarretar prejuízo processual à própria parte onerada) mostra-se insuficiente, nos dias atuais, para a explicação do fenômeno.

11. Não se desconhece que a técnica legislativa fundada nos ônus processuais é de grande serventia para o impulso processual. Isso porque, o risco de prejuízo processual causado à parte pelo não cumprimento de determinado ônus funciona como eficaz ferramenta (até mesmo psicológica) de encorajamento para a prática do ato. Além disso, em caso de descumprimento, a aplicação da consequência processual costuma, em regra, ser instrumento mais célere e efetivo para as finalidades do processo.

12. Casos há, no entanto, em que a simples aplicação da técnica do ônus é incapaz de sanar a lacuna probatória (tal como ocorre, por exemplo, quando o litígio versa sobre matéria de ordem pública, hipótese em que não se admite a confissão ficta). Essa constatação, somada ao crescente reconhecimento dos poderes instrutórios do juiz impõe reconhecer a existência de autênticos deveres das partes e também do juiz em matéria de prova.

13. Com efeito, à medida que se reconhece que a prova não se produz apenas no interesse da parte, mas também do Poder Judiciário no esclarecimento dos fatos e no alcance dos objetivos públicos da atividade jurisdicional (que pode, inclusive, determinar sua produção de ofício e independentemente da anuência das partes, sujeitando-as à sua produção e às suas consequências), a prova se aproxima também da noção de dever, cuja principal característica consiste, justamente, no fato de ser realizado no interesse alheio, não necessariamente comungado pelo sujeito cuja conduta se pretende vincular.

14. Relembre-se, ainda, que o artigo 339 do CPC traz disposição expressa no sentido de que "ninguém se exime do dever de colaborar com o Poder Judiciário para o descobrimento da verdade".

15. Conclui-se, assim, que se não se pode exigir dos litigantes a produção espontânea de provas contrárias a seus interesses, o que contrariaria a própria natureza humana, também não se pode deixar de reconhecer o dever das partes de cooperar com a produção de toda e qualquer prova que se mostre imprescindível à solução da lide, sendo que, na inércia, o ordenamento jurídico autoriza a imposição de sanções lato sensu aos litigantes, que abarcam desde consequências processuais desfavoráveis, até a aplicação de sanções pecuniárias, medidas coercitivas ou até mesmo sub-rogatórias pelo juiz, tudo a depender da situação peculiar de cada caso. 
16. Nesse contexto, a antiga visão da prova como simples ônus da parte deve ser substituída por uma visão tridimensional do instituto, que se revela como ônus das partes, como poder do juiz e direito (ou poder) constitucional das partes, e, ainda, como projeção do dever geral de colaboração com o Poder Judiciário, sendo que todas essas concepções da prova encontram assento constitucional e infraconstitucional em nosso ordenamento jurídico.

17. Essa conclusão, aliás, também decorre do reconhecido conteúdo ético do processo, cujas regras - que têm aplicação precípua no âmbito probatório - induzem a exigência de determinados comportamentos colaborativos do Juiz com as partes e destas com aquele.

18. De fato, o processo civil contemporâneo, direcionado que é à efetividade, não pode tolerar condutas que visem a elidir ou conspurcar a realização do direito material que se dá por seu intermédio, exigindo-se das partes uma conduta processual adequada, o que também se aplica à instrução probatória.

19. O princípio da probidade, materializado no dever de lealdade processual, serve, pois, como freio ético e legal à atuação em juízo, mediante a fixação de limites socialmente aceitáveis de comportamento, cuja inobservância gera sanções e responsabilidades processuais. O juiz, por sua vez, na qualidade de diretor do processo, além de ter o dever de cobrar das partes uma postura processualmente adequada (art. 125, CPC), também está sujeito, ele próprio, à observância de normas ético-jurídicas, responsabilizando-se por eventuais danos causados às partes em razão da inobservância desses deveres.

20. O dever de lealdade processual, por seu turno, abarca também o dever de veracidade, que se revela como uma de suas facetas mais sensíveis, prevista em diversos ordenamentos jurídicos, e cuja finalidade é evitar que o juiz profira decisão com base em convicção fundada em falsos subsídios trazidos pelas partes.

21. É crescente a preocupação do processo civil contemporâneo com o conteúdo ético do processo, o que se revela, no caso brasileiro, pelas diversas inovações legislativas verificadas nos últimos anos no sentido de reprimir condutas abusivas e afastar o processo das armadilhas criadas pelas práticas desleais.

22. Justamente nesse contexto, alguns estudiosos têm sustentado a aplicação da cláusula geral de boa-fé no processo civil, como fonte criadora dos deveres de cooperação 
e colaboração e, ao mesmo tempo, como regra limitadora do exercício das posições jurídicas na relação processual.

23. A influência da boa-fé sobre todo o ordenamento extrai-se, no caso brasileiro, dos próprios postulados da Constituição Federal, que tem na construção de uma sociedade livre, justa e solidária um dos objetivos fundamentais do Estado organizado, elevando assim, ao grau máximo, o dever de cooperação, solidariedade e lealdade entre os cidadãos no trato social.

24. O paradigma da boa-fé objetiva, por sua vez, albergado expressamente pelo Código Civil brasileiro em vigor, veio estabelecer novos limites para o exercício das posições nas relações jurídicas, vedando comportamentos que, embora legal ou contratualmente assegurados, não se conformam aos standarts impostos pela cláusula geral. E, a aplicação do princípio da boa-fé objetiva ao processo tem servido também para justificar a existência de deveres acessórios aos litigantes, dentre os quais, precipuamente, o de colaborar, cooperar para a realização dos escopos do processo, fundamentando, inclusive, a inadmissibilidade do comportamento contraditório no processo, o que já vem sendo acolhido em sede jurisprudencial.

25. Os atuais paradigmas do processo estão, portanto, a exigir das partes e de todos aqueles que atuam em juízo uma conduta processual adequada, condizente com a dignidade desse instrumento público de solução de conflitos, e, ao mesmo tempo, do órgão jurisdicional, uma postura mais atenta, participativa e enérgica com relação à identificação e coibição dos comportamentos desleais, desonestos e protelatórios dos litigantes no processo, que tanto obstaculizam o regular trâmite processual e o alcance de seus objetivos.

26. Impõe-se, contudo, não perder de vista que esse ativismo exigível do julgador, na qualidade de diretor do processo, não pode transformar o processo em algo ditatorial, nem o exercício desses poderes-deveres do juiz pode se dar ao arrepio das garantias constitucionais do contraditório, da ampla defesa, do acesso à justiça, etc.

27. É justamente nesse contexto que a doutrina processual civil tem se dedicado, nos últimos anos, a revisitar determinados institutos e temas processuais, no intuito de adaptá-los a essa nova perspectiva metodológica do direito processual.

28. E, essa revisão também abarca uma nova interpretação da chamada "divisão de trabalho" entre o juiz e as partes na fase probatória, reconhecendo-se a existência de um 
dever de colaboração das partes e do juiz para a elucidação dos fatos controvertidos, o que um traz como consequência a exigência de determinadas condutas, determinados comportamentos desses sujeitos na instrução probatória.

29. Em nosso estudo, trouxemos, a título exemplificativo, alguns desses comportamentos tidos como "manifestações" do dever de colaboração na instrução processual.

30. No que se refere ao juiz, identificamos, além do exercício dos poderes-deveres instrutórios e de suas limitações, outros exemplos colhidos na doutrina, na jurisprudência e nas próprias regras processuais, dessas condutas exigíveis do magistrado no curso da instrução processual. São eles: (a) os deveres de esclarecimento, prevenção, consulta e auxílio para com os litigantes; (b) o dever de fixação dos pontos controvertidos e, consequentemente, do objeto da prova; (c) o dever de intimar previamente as partes de eventual decisão de inversão do ônus da prova, oportunizando ao onerado a chance efetiva de se desincumbir do encargo antes inexistente; (d) o dever de não valorar antecipadamente a prova, inadmitindo sua produção sob o argumento de "já estar convencido o juiz" e, ainda, (e) o dever de submissão de toda a qualquer prova ao crivo das partes.

31. Ressaltamos, por outro lado, os limites que são impostos pelo próprio ordenamento à atuação do magistrado na instrução processual, dentre os quais a exigência da razoável duração do processo; a relação inversamente proporcional entre o grau de disponibilidade dos direitos contrapostos e o exercício dos poderes instrutórios pelo juiz; a necessidade de tratamento isonômico das partes, e, ainda, a exigência de adstrição do juiz ao pedido e à causa de pedir definidos pelas partes na fase postulatória, não podendo o juiz avançar sobre matéria ou pedido não deduzido pelas partes, de sorte a alterar os limites objetivos da lide, nem agir como investigador particular dos fatos, investigando fontes de prova não mencionadas pelas partes e colhendo dados que extrapolem os limites da controvérsia fática instaurada dos autos.

32. Já sob a ótica da atuação das partes, identificamos (a) os deveres de exposição dos fatos conforme a verdade, colaboração no seu esclarecimento e submissão aos poderes instrutórios do juiz e também (b) os deveres de comparecer em juízo e submeterse a interrogatório ou depoimento pessoal, submeter-se à inspeção judicial e dar cumprimento às ordens judiciais. 
33. Destacamos, no entanto, que o dever de colaboração imposto por lei às partes cede, em algumas hipóteses, ora a certos interesses ligados à defesa da esfera privada da pessoa, ora diante de outros deveres a que sujeitos os detentores das informações relevantes para o processo, hipóteses tratadas pela doutrina como "regras de exclusão" e que são previstas no próprio CPC e também em leis extravagantes.

34. Reconhecida a existência de autênticos deveres processuais em matéria de prova, cumpriu-nos, ao fim e ao cabo, tratar das consequências processuais de sua inobservância.

35. Com relação às partes, as consequências impostas à violação do dever de colaboração, como visto, podem assumir diferentes formas no processo, sendo a primeira delas e mais frequentemente aceita a presunção de veracidade do fato que se pretendia provar.

36. Assim, em algumas hipóteses, a própria lei toma a recusa da parte em colaborar como indicativo do interesse em ocultar provas cujo resultado lhe seria desfavorável, criando uma presunção legal (relativa) de veracidade do fato que se pretendia provar. Em outros casos, a lei, ao invés de estabelecer diretamente a presunção, autoriza o juiz a fazêlo, analisando o comportamento da parte em conjunto com os demais elementos de prova constantes dos autos e dele extraindo consequências probatórias (presunção hominis).

37. Como se viu, portanto, é grande a influência que o comportamento das partes em juízo produz no magistrado, podendo ter, inclusive, enquanto fato jurídico processual, influência na formação da convicção judicial. A matéria, no entanto, suscita relevantes indagações, tanto no Brasil como diversos ordenamentos estrangeiros, no diz respeito à necessidade ou não de previsão legal expressa dos comportamentos com eficácia probatória e ao valor que deve ser dado a esse elemento de convicção.

38. No Brasil, a doutrina, com fundamento no princípio da atipicidade das provas, do livre convencimento e na permissão legal do emprego das "máximas da experiência", parece se inclinar favoravelmente ao uso do comportamento processual da parte em juízo como indício, fonte de uma presunção hominis. No entanto, entende-se que o juiz somente está autorizado a extrair eficácia probatória de comportamentos processuais que permitam ilações racionais, o que não se confunde com "juízos sensoriais". Além disso, a doutrina majoritária defende que a eficácia probatória do comportamento da parte deve ter relação com a produção de prova e não com seu comportamento em geral no processo. Daí a 
fundamental importância da fundamentação da decisão, que, no caso específico, funciona como elemento indispensável de controle, pelas partes, da operação lógica efetuada pelo juiz, possibilitando, em grau de recurso, o questionamento sobre a eficácia probatória dos fatos jurídicos tomados como premissas da decisão e o acerto da conclusão obtida pelo juiz.

39. A presunção de veracidade dos fatos que se pretendia provar, no entanto, se por um lado não é aplicável em todas as hipóteses de descumprimento do dever de colaboração na instrução (tal como ocorre quando o litígio versa sobre matéria de ordem pública ou quando imprescindível determinada prova cuja produção é renitentemente omitida pela parte), por outro, não esgota as consequências às partes de sua inobservância.

40. Nesse contexto, também se entendem plenamente aplicáveis as medidas coercitivas, sub-rogatórias e até mesmo sanções pecuniárias, como é o caso da multa por litigância de má-fé ou da multa por descumprimento do provimento mandamental em caso de violação do dever de colaboração das partes, entendendo-se, quanto a estas últimas, a possibilidade, inclusive, de serem cumuladas com a presunção de veracidade dos fatos.

41. Por fim, no tocante às consequências jurídicas da ausência de colaboração do juiz, a matéria, além de escassamente tratada na vasta doutrina pesquisada, é permeada de inúmeras dificuldades.

42. O tema da responsabilidade do juiz pelos atos praticados no processo é recorrente e central na vida judiciária de um país democrático e está também umbilicalmente ligado à problemática da independência do juiz e à necessidade de garantir sua imparcialidade.

43. Por outro lado, como reconhece a doutrina, se a cada poder do juiz correspondelhe também um dever de cumpri-lo, o aumento dos poderes do juiz na direção e instrução do processo deve corresponder a um aumento de sua responsabilidade, podendo o juiz ser responsabilizado por falta ou excesso no exercício dos poderes que a lei processual lhe atribui.

44. Assim, pelo que se verificou ao longo do estudo, o ordenamento jurídico brasileiro, se de um lado impõe regras de conduta ético-jurídicas também ao magistrado, na qualidade de diretor do processo, autoriza, em regra geral, sua responsabilização civil e administrativa (e até mesmo penal) em casos de infringência aos seus deveres funcionais, notadamente quando causadores de danos aos jurisdicionados. 
45. No entanto, no que se refere ao chamado dever de colaboração na instrução processual, por se tratar de matéria intimamente ligada ao convencimento judicial resguardada, portanto, pelos princípios da persuasão racional e do livre convencimento motivado -, afora situações patológicas, em que identificado o dolo do órgão jurisdicional (conforme exemplos tratados ao longo do estudo), não nos parece que seja defensável uma tal possibilidade, ao menos assim genérica, de responsabilidade do juiz quando verificada a falta de colaboração na instrução processual, nem mesmo naquelas hipóteses que arrolamos como manifestações do dever de colaboração do juiz na instrução processual.

46. Assim, sem que se possa prescindir dos instrumentos de prevenção e repressão de eventuais desvios dos deveres funcionais do juiz, ou seja, para atacar as patologias, esse comprometimento e a consciência de sua função social se dão mais no plano de sua formação e educação do que propriamente no de aplicação de medidas repressivas.

47. A nosso ver, portanto, a questão está mais intimamente relacionada à necessidade de conscientização do juiz atual sobre a relevante função social que desempenha no processo, os objetivos públicos por ele perseguidos e à exigência de uma nova postura que se amolde à feição do Estado contemporâneo de Direito. 


\section{REFERÊNCIAS}

ABDO, Helena Najjar. O abuso do processo. São Paulo: Ed. Revista dos Tribunais, 2007.

AMENDOEIRA JUNIOR, Sidnei. Poderes do juiz e tutela jurisdicional: a utilização racional dos poderes do juiz como forma de obtenção da tutela jurisdicional efetiva, justa e tempestiva. São Paulo: Atlas, 2006.

ARAGÃO, E. D. Moniz. Regras de prova no Código Civil. Revista de Processo, Rio de Janeiro, ano 29, n. 116, jul./ago. 2004.

ARAÚJO, Edmir Netto de. Responsabilidade do Estado por ato jurisdicional. São Paulo: Ed. Revista dos Tribunais, 1981.

ARRUDA ALVIM, José Manoel de. Deveres das partes e dos procuradores no direito processual civil brasileiro (a lealdade no processo). Revista de Processo, São Paulo, v. 18, n. 69, p. 7-20, jan./mar. 1993.

. Manual de direito processual civil. 6. ed. São Paulo: Ed. Revista dos Tribunais, 1995. v. 1 e 2.

Manual de direito processual civil. 15. ed. rev. atual. e ampl. São Paulo: Ed. Revista dos Tribunais, 2012.

ARRUDA, Miranda. O direito fundamental à razoável duração do processo. Brasília: Brasília Jurídica, 2006.

ASSIS, Araken de. Dever de veracidade das partes no processo civil. Páginas do Direito, 31. Ago. 2012. Disponível em: <www.tex.pro.br/tex/listagem-de-artigos/362-artigos-ago2012/8769-dever-de-veracidade-das-partes-no-processo-civil>.

BANDEIRA DE MELLO, Celso Antônio. Discricionariedade e controle jurisdicional. 2. ed. São Paulo: Malheiros Ed., 1998.

BAPTISTA DA SILVA, Ovídio. Jurisdição e execução na tradição romano-canônica. Rio de Janeiro: Forense, 2007.

BARBOSA MOREIRA, José Carlos. A Constituição e as provas ilicitamente obtidas. In: . Temas de direito processual: sexta série. São Paulo: Saraiva, 2006.

A função social do processo civil moderno e o papel do juiz e das partes na direção e instrução do processo. Revista de Processo, São Paulo, n. 37, jan./mar. 1985.

O juiz e a prova. In: . Temas de direito processual: segunda série. São

Paulo: Saraiva, 1988. 
BARBOSA MOREIRA, José Carlos. Julgamento e ônus da prova. In: Temas de direito processual: segunda série. São Paulo: Saraiva, 1988.

. La negativa de la parte a someterse a una pericia medica (según el nuevo Código Civil brasileño). In: Temas de direito processual: nona série. São Paulo: Saraiva, 2007. p. 159-166.

. O neoprivatismo no processo civil. In: Temas de direito processual: nona série. São Paulo: Saraiva, 1997.

. Notas sobre a inversão do ônus da prova em benefício do consumidor. Revista de Direito do Consumidor, São Paulo, n. 22, p. 135-149, abr./jun. 1997.

Os novos rumos do processo civil brasileiro. Revista de Processo, São Paulo, v. 20, n. 78, p. 133-144, abr./jun. 1995.

. Os poderes do juiz na direção e instrução do processo. In: Temas de direito processual: $4^{\mathrm{a}}$ série. São Paulo: Saraiva, 1989.

. As presunções e a prova. In: . Temas de direito processual. São Paulo: Saraiva, 1977.

. O problema da divisão de trabalho entre juiz e partes: aspectos terminológicos. In: Temas de direito processual: $4^{\text {a }}$ série. São Paulo: Saraiva, 1989.

. O processo civil contemporâneo: um enfoque comparativo. Revista Forense, Rio de Janeiro, v. 370, p. 53-65, nov./dez. 2003.

. Provas atípicas. Revista de Processo, São Paulo, v. 19, n. 76, p. 114-126, out./dez. 1994.

Regras de experiência e conceitos jurídicos indeterminados. In: Temas de Direito Processual Civil: segunda série. São Paulo: Saraiva, 1988.

A responsabilidade das partes por dano processual no direito brasileiro. In: . Temas de direito processual: primeira série: São Paulo: Saraiva, 1988.

. Sobre a 'participação' do juiz no processo civil. In: Temas de direito processual: $4^{\text {a }}$ série. São Paulo: Saraiva, 1989.

BEDAQUE, José Roberto dos Santos. Direito e processo. São Paulo: Malheiros Ed., 1995.

- Garantia da amplitude de produção probatória. In: Garantias Constitucionais do Processo Civil. Homenagem aos 10 anos da Constituição Federal de 1988. (Coord.) José Rogério Cruz e Tucci, 1 ed. São Paulo: Ed. Revista dos Tribunais, 1999. 
BEDAQUE, José Roberto dos Santos. Poderes instrutórios do juiz. 4. ed. São Paulo: Ed. Revista dos Tribunais, 2009.

BERALDO, Ana Carolina. O comportamento dos sujeitos processuais como obstáculo à razoável duração do processo. 2010. Dissertação (Mestrado) - Universidade de São Paulo. 2010.

BOBBIO, Norberto. Liberalismo e democracia. Tradução Marco Aurelio Nogueira. São Paulo: Brasiliense, 2000.

BOURSIER, Marie-Emma. Le principle de loyauté en droit processuel. Paris: Dalloz, 2003.

BUENO, Cassio Scarpinella. Curso sistematizado de direito processual civil. v. 1. 6. ed. rev. atual e ampl. São Paulo: Saraiva, 2012.

BULOW, Oscar. La teoria de las excepciones procesales y los presupuestos procesales. México, D.F.: Instituto de la Judicatura Federal Biblioteca Felipe Tena Ramírez. Disponível em: <http://www.ijf.cjf.gob.mx/Bibliotecadigital/von_b\%C3\%BClow.asp>.

CALAMANDREI, Piero. Eles, os juízes, vistos por um advogado. São Paulo: Martins Fontes, 1995.

_. Il processo come giuoco. Rivista de Diritto Processuale, Padova, v. 5, pt. 1, p. 24$51,1950$.

CÂMARA. Alexandre Freitas. Poderes instrutórios do juiz e processo civil democrático. Revista de Processo, São Paulo, ano 32, n. 153, nov. 2007.

CAMBI, Eduardo. A prova civil: admissibilidade e relevância. São Paulo: Ed. Revista dos Tribunais, 2006.

CAPPELLETTI, Mauro. Juízes irresponsáveis? Trad. Carlos Alberto Alvaro de Oliveira. Porto Alegre: SAFE, 1989.

. La testimonianza della parte nel sistema della'oralità. Milano: Giuffrè, 1974.

. Valor actual del principio de oralidade: la oralidad y las pruebas en el proceso civil. Trad. Santiago Santis Melendo. Buenos Aires: Ejea, 1972.

; GARTH, Bryant. Acesso à justiça. Trad. e Rev. Ellen Gracie Northfleet. Porto Alegre: Sergio Antonio Fabris Editor, 2002.

CARNELUTTI, Francesco. Como se hace um processo. Bogotá: Temis, 1994.

Diritto e processo. Napoli: Morano, 1958. 
CARNELUTTI, Francesco. Giuoco e processo. Rivista di Diritto Processuale, Milano, pt. 1, p. 101-111, 1951.

. A prova civil. 2. ed. Campinas: Bookseller, 2002.

. Sistema di diritto processuale civile. Padova: Cedam, 1936. v. 1.

CARPENA, Marcio Louzada. Da (des) lealdade no processo civil: visões críticas do processo civil brasileiro. Porto Alegre: Livr. do Advogado, 2005.

CARPI, Federico. A responsabilidade do juiz. Revista de Processo, Sao Paulo, v.20, n. 78, p. 123-132, abr./jun. 1995.

CARVALHO FILHO, Milton Paulo de. Ainda a inversão do ônus da prova no código de defesa do consumidor. Revista dos Tribunais, São Paulo, v. 92, n. 807, p. 56-81, jan. 2003.

CHIOVENDA, Giuseppe. Instituições de direito processual civil. Trad. Paolo Capitanio; com anotações Enrico Tullio Liebman. 2. ed. Campinas: Bookseller, 2000. v. 2.

- Princippi di diritto processuale civile: le azione, il processo de cognizione. Napoli: Jovene, 1980.

CIPRIANI, Franco. El autoritarismo procesal (y las pruebas documentales) Revista Ius et Praxis, año 13, n. 12. Disponível em <http://www.scielo.cl/pdf/iusetp/v13n2/art03.pdf>.

El proceso civil italiano entre revisionistas y negacionistas. In: MONTERO AROCA, Juan (Coord.). Proceso civil e ideologia: un prefacio, una sentencia, dos cartas y quince ensayos. Valencia: Tirant Lo Blanch, 2006. p. 51-64.

CORDERO, Franco. Le situazione soggettive nel processo penale. Torino: Giapichelli, 1957.

CORDOPATRI, Francesco. L'abuso del processo. Padova: Cedam, 2000. v. 1 e v. 2.

COSTA E SILVA, Paula. Acto e processo. Coimbra: Ed., 2003.

COUTURE, Eduardo. El deber de decir la verdade en juicio civil. Montevideo: Barreiro Y Ramos, 1938.

CRESCI SOBRINHO, Elicio de. Contribuição ao estudo do dever de veracidade das partes no processo civil: aspectos do Anteprojeto de Codigo de Processo Civil, de autoria do professor Alfredo Buzaid. São Paulo, Lael, 1972.

CRUZ E TUCCI, José Rogério. Lineamentos da nova reforma do CPC: Lei 10.352, de 26.12.2001, Lei 10.358, de 27.12.2001. São Paulo: Ed. Revista dos Tribunais, 2002. 
CRUZ E TUCCI, José Rogério. Repressão ao dolo processual: o novo art. 14 do CPC. Revista Jurídica, Porto Alegre, v. 50, n. 292, fev. 2002.

- Tempo e processo: uma análise empírica das repercussões do tempo na fenomenologia processual (civil e penal). São Paulo: Ed. Revista dos Tribunais, 1997.

; AZEVEDO, Luiz Carlos de. Lições de história de processo civil romano. 1. ed. 2 tir. São Paulo: Ed. Revista dos Tribunais, 2001.

; TUCCI, Rogério Lauria. Devido processo legal e tutela jurisdicional. São Paulo: Ed. Revista dos Tribunais, 2003.

CUNHA, Oscar. Atti del Congresso Internazionale di Diritto Processuale Civile. Padova, 1953.

DALL'ALBA, Felipe Camilo. A ampla defesa como proteção dos poderes das partes: proibição de inadmissão da prova por já estar convencido o juiz. In: KNIJNIK, Danilo; CARPES, Artur Thompsen (Coords.). Prova Judiciária: estudos sobre o novo direito probatório. Porto Alegre: Livr. do Advogado Ed., 2007. p. 93-104.

DALLARI, Dalmo de Abreu. Elementos da teoria geral do Estado. 19 ed. atual. São Paulo: Saraiva, 1995.

DEMARI, Lisandra. Juízo de relevância da prova. In: KNIJNIK, Danilo; CARPES, Artur Thompsen (Coords.). Prova Judiciária: estudos sobre o novo direito probatório. Porto Alegre: Livr. do Advogado Ed., 2007. p. 171-179.

DE STEFANO, Giuseppe. Note sull'abuso del processo. Rivista Diritto Processuale, Padova, v. 19, pt. 1, p. 582-600, 1964.

DEVIS ECHANDÍA, Hernando. Teoría general del proceso: aplicable a toda clase de procesos : nociones generales, sujetos de la relación jurídica procesal, objeto, iniciación, desarrollo y terminación del proceso. Buenos Aires: Editorial Universidad, 1997.

Teoria general de la prueba judicial. 5. ed. Buenos Aires: Zavalia, 1981. t. 1 e t. 2.

DI PIETRO, Maria Sylvia. Direito administrativo. 25. ed. São Paulo: Atlas, 2012.

DINAMARCO, Cândido Rangel. Fundamentos do processo civil moderno. 3. ed. São Paulo: Malheiros, 2000. t. 1 e t. 2.

Instituições de direito processual civil. 6. ed. São Paulo: Malheiros Ed., 2009. v.

1, v. 2 e v. 3.

. A instrumentalidade do processo. 13. ed. São Paulo: Malheiros Ed., 2008. 
DINAMARCO, Pedro da Silva. Ônus processuais: limites à aplicação das consequências previstas para o seu não cumprimento. 2007. Tese (Doutorado) - Universidade de São Paulo, 2007.

DUARTE, Nestor. Arts. $1^{\circ}$ a 232: parte geral. In: PELUSO, Cezar (Coord.). Código Civil comentado: doutrina e jurisprudência. 2. ed. Barueri, SP: Manole, 2008, v. 1, p. 1-168.

FAZZALARI, Elio. Note in tema de diritto e processo. Milano: Giuffrè, 1957.

FERREIRA, William dos Santos. Princípios fundamentais da prova cível. 2008. Tese (Doutorado) - Pontifícia Universidade Católica de São Paulo, São Paulo, 2008.

FINZI, Enrico. Questioni controverse in tema di esecuzione provvisoria. Rivista di Diritto Processuale Civile, Padova, t. 2, 1926.

FORNACIARI, Fernando Hellmeister Clito. Ônus da prova no processo civil. 2005. Dissertação (Mestrado) - Universidade de São Paulo, 2005.

GOMES, Sérgio Alves. Os poderes do juiz na direção e instrução do processo civil. Rio de Janeiro: Forense, 1997.

GORDILLO, Agustin. Princípios gerais de direito público. São Paulo: Ed. Revista dos Tribunais, 1977.

GORLA, Gino. Comportamento processuale dele parti e convencimento del giudice. Rivista di Diritto Processuale, Milano, n. 12, 1935.

GRAU, Eros Roberto. A ordem econômica na Constituição de 1988. 7. ed. São Paulo: Malheiros, 2002.

GRINOVER, Ada Pellegrini. Abuso do processo e resistência às ordens judiciárias: o "contempt of court". In: A marcha do processo. Rio de Janeiro: Forense Universitária, 2000.

O conteúdo da garantia do contraditório. In: Novas tendências do direito processual de acordo com a Constituição de 1998. Rio de Janeiro: Forense Universitária, 2001.

Paixão e morte do "contempt of court" brasileiro (art. 14 do Código de Processo Civil). In: CALMON, Eliana (Org.). Direito processual: inovações e perspectivas: estudos em homenagem ao Ministro Sálvio de Figueiredo Teixeira. São Paulo: Saraiva: 2003. p. 111.

O processo em sua Unidade II. Rio de Janeiro: Forense, 1984. 
GRINOVER, Ada Pellegrini; CINTRA, Antônio Carlos de Araújo; DINAMARCO, Cândido Rangel. Teoria geral do processo. 25. ed. São Paulo: Malheiros Ed., 2009.

et al. Código Brasileiro de defesa do consumidor: comentado pelos autores do anteprojeto. 9. ed. Rio de Janeiro: Forense Universitária, 2007.

GROSSMAN, Kaethe. O dever de veracidade das partes no processo civil (aspecto doutrinário). Revista Forense, Rio de Janeiro, v. 101, p. 279-290, jan. 1945.

GUERRA, Marcelo Lima. Estudos sobre o processo cautelar. 1. ed. 2 tir. São Paulo: Malheiros Ed., 1997.

HOFFMAN, Paulo. Razoável duração do processo. São Paulo: Quartier Latin, 2006.

KNIJNIK, Danilo. A prova nos juízos cível, penal e tributário. Rio de Janeiro: Forense Jurídica, 2007.

KOMATSU, Roque. Notas em torno dos deveres processuais dos juízes. In:

SALLES, Carlos Alberto de (Coord.). As grandes transformações do processo civil brasileiro: homenagem ao professor Kazuo Watanabe. São Paulo: Quartier Latin, 2009.

LACERDA, Galeno. Comentários ao Código de Processo Civil. 7. ed. Rio de Janeiro: Forense, 1998. v. 8, t. 1.

Processo e cultura. Revista de Direito Processual Civil, v. 3, 1961.

LASPRO, Oreste Nestor de Souza. A responsabilidade civil do juiz. São Paulo: Ed. Revista dos Tribunais, 2000.

LIEBMAN, Enrico Tullio. Fondamento del principio dispositivo: problemi del processo civile. Milano: Morano, 1962.

Manual de direito processual civil. Tradução e notas de Cândido Rangel Dinamarco. 3. ed. São Paulo: Malheiros, Ed., 2005. v. 1.

Manuale de diritto processuale civil. 3. ed. Milano: Guiffrè, 1973-1976.

LOPES, João Batista. A prova no direito processual civil. São Paulo: Ed. Revista dos Tribunais, 2002.

LOUREIRO FILHO, Lair da Silva. Responsabilidade pública por atividade judiciária. São Paulo: Ed. Revista dos Tribunais, 2005.

MARINONI, Luiz Guilherme; ARENHART, Sérgio Cruz. Comentários do Código de Processo Civil. São Paulo: Ed. Revista dos Tribunais, 2008. 
MARINONI, Luiz Guilherme; ARENHART, Sérgio Cruz. Prova. São Paulo: Ed. Revista dos Tribunais, 2009.

; Código de Processo Civil comentado. São Paulo: Ed. Revista dos Tribunais, 2008.

MITIDIERO, Daniel. O Projeto do CPC: críticas e propostas. São Paulo: Ed. Revista dos Tribunais, 2010.

MARQUES, José Frederico. Instituições de direito processual civil. Rio de Janeiro: 1958. v. 1 e v. 2.

MARTINS-COSTA, Judith. A boa-fé no direito privado. São Paulo: Ed. Revista dos Tribunais, 1999.

A ilicitude derivada do exercício contraditório de um direito: o renascer do venire contra factum proprium. Revista Ajuris, Porto Alegre, no 36, n. 97, mar. 2005.

MATTOS, Cecília. O ônus da prova no Código de Defesa do Consumidor. 1993. Dissertação (Mestrado) - Faculdade de Direito, Universidade de São Paulo, São Paulo, 1993.

MEDINA, José Miguel Garcia. Execução civil: princípios fundamentais. Sao Paulo: Ed. Revista dos Tribunais, 2002.

MEDINA, Paulo Roberto de Gouvêa. A prova das intenções no processo civil. Revista de Processo, Rio de Janeiro, ano 29, n. 115, p. 74-85, maio/jun. 2004.

MENDONÇA LIMA, Alcides. O dever de verdade no Código de Processo Civil brasileiro. Revista Forense, Rio de Janeiro, ano 54, n. 172, p. 42-43, jul./ago. 1957.

O princípio da probidade no Código de Processo Civil brasileiro. Revista de Processo, Rio de Janeiro, ano 4, out./dez. 1979.

MICHELI, Gian Antonio. La carga de la prueba. Buenos Aires: Ejea, 1961.

L'onere della prova. Padova: CEDAM, 1966.

. Teoria geral da prova. Revista de Processo, São Paulo, v. 1, n. 3, p. 162-168, jul./set. 1976.

MILHOMENS, Jonatas. Da presunção da boa-fé no processo civil. Rio de Janeiro: Forense, 1961.

MIRABETE, Julio Fabrini. Código de Processo Penal interpretado. 8. ed. São Paulo: Atlas, 2001. 
MITIDIERO, Daniel. Colaboração no processo civil: pressupostos sociais, lógicos e éticos. São Paulo: Ed. Revista dos Tribunais, 2009.

. Comentários ao Código de Processo Civil. São Paulo: Memória Jurídica Ed.,

2006. t. 3 .

MONTERO AROCA, Juan. El proceso civil llamado 'social' como instrumento de justicia autoritária. In: MONTERO AROCA, Juan (Coord.). Proceso civil e ideologia: un prefacio, una sentencia, dos cartas y quince ensayos. Valencia: Tirant Lo Blanch, 2006. p. 129-165.

NAGAO, Paulo Issamu. Papel do juiz na efetividade do processo civil contemporâneo. 2012. Tese (Doutorado) - Universidade de São Paulo, 2012.

NERY JÚNIOR, Nelson. Princípios do processo na Constituição Federal: processo civil, penal e administrativo. 9. ed. rev. e atual. São Paulo: Ed. Revista dos Tribunais, 2009.

; ANDRADE NERY, Rosa Maria. Código de Processo civil comentado e Legislação processual civil extravagante. 12. ed. São Paulo: Ed. Revista dos Tribunais, 2012.

dos Tribunais, 2007.

OLIVEIRA, Ana Lúcia Iucker Meirelles de. Litigância de má-fé. São Paulo: Ed. Revista dos Tribunais, 2000.

OLIVEIRA, Carlos Alberto Alvaro de. Do formalismo no processo civil: proposta de um formalismo-valorativo. 4. ed. rev. atual e aum. São Paulo: Saraiva, 2010.

. Do formalismo-valorativo no confronto com o formalismo excessivo. In: DIDIER JR. Fredie (Coord.). Leituras complementares de processo civil. 8. ed. São Paulo: JusPodium, 2010. (Coleção Leituras Complementares).

. O juiz e o princípio do contraditório. Revista de Processo, São Paulo, v. 19, n. 73, p. 31-38, jan./mar. 1994.

. Poderes do juiz e visão cooperativa do processo. Revista da Ajuris, Porto Alegre, v. 30, n. 90 , p. 55-84, jun. 2003.

- Problemas atuais da livre apreciação da prova. Disponível em: <www.ufrgs.br/ppgd/doutrina/oliveir3.htm>.

O processo civil na perspectiva dos direitos fundamentais. In: . Processo e constituição. Rio de Janeiro: Forense, 2004. 
PACÍFICO, Luiz Eduardo Boaventura. O ônus da prova no direito processual. 1998. Dissertação (Mestrado) - Faculdade de Direito, Universidade de São Paulo, São Paulo, 1998.

PATTI, Salvatore. Libero convencimento e valutazione delle prove. Rivista di Diritto Processuale, Milano, ano 40, n. 3, 1985.

PICARDI, Nicola. Appunti di diritto processuale civile: processo ordinário di cognizione le impugnación. Milano: Giufrè, 2003.

PITT, Gioconda Fianco. Dever de veracidade no processo civil brasileiro e sua relação com o instituto da Discovery no processo norte-americano da common law. In: KNIJNIK, Danilo; CARPES, Artur Thompsen (Coords.). Prova Judiciária: estudos sobre o novo direito probatório. Porto Alegre: Livr. do Advogado Ed., 2007.

PONTES DE MIRANDA, Francisco Cavalcante. Comentários ao Código de Processo Civil. Rio de Janeiro: Forense, 1977. t. 4.

. Comentários ao Código de Processo Civil. Rio de Janeiro: Forense, 1974. t. 6.

_. Comentários ao Código de Processo Civil. 4. ed. Rio de Janeiro: Forense, 1997. v. 3 , v. 6 .

PUOLI, José Carlos Baptista. Os poderes do juiz e as reformas do processo civil. São Paulo: Juarez de Oliveira, 2002.

RAMÓN MENDEZ, Francisco. Abuso de derecho en el processo? In: BARBOSA MOREIRA, José Carlos (Coord.). Abuso dos direitos processuais. Rio de Janeiro: Forense, 2000 .

RAMOS, Carlos Henrique. Processo civil e o princípio da razoável duração do processo. Curitiba: Juruá, 2008.

RANGEL, Rui Manuel de Freitas. O ónus da prova no processo civil. Coimbra: Almedina, 2000.

REALE, Miguel. Lições preliminares de direito. 27. ed. São Paulo: Saraiva, 2006.

REGO, Hermenegildo de Souza. Dever de sigilo e escusa de depor. Revista de Processo. São Paulo, n. 9, n. 33, jan./mar. 1984.

RESCIGNO, Pietro. L'abuso del diritto. Bolonha: Il Mulino, 1998.

RIBEIRO, Darci Guimarães. Provas atípicas. Porto Alegre: Livr. do Advogado, 1998. 
RIBEIRO, Darci Guimarães. O sobreprincípio da boa-fé processual como decorrência do comportamento da parte em juízo. Revista da Ajuris, Porto Alegre, v. 31, n. 95, p. 71-87, set. 2004.

RIBEIRO, Débora de Oliveira. Inversão do ônus da prova no Código de Defesa do Consumidor. 2005. (Dissertação) - Faculdade de Direito, Universidade de São Paulo, São Paulo, 2005.

RIGHI, Ivan. Eficácia probatória do comportamento das partes. Revista da Faculdade de Direito da UFPR, Curitiba, n. 20, 1981.

RODRIGUES, Silvio. Direito civil. 20. ed. rev. e atual. São Paulo: Saraiva, 2003. v. 4.

ROSEMBERG, Leo. La carga de la prueba. Traducción de Ernesto Krotoschin. Buenos Aires, Ed. Juridicas Europa-America, 1956.

RULli NETO, Antonio. Controle externo do Poder Judiciário no Brasil. 2007. Tese (Doutorado) - Faculdade de Direito, Universidade de São Paulo, 2007.

SANTÍS MELENDO, Santiago. La prueba, los grandes temas de derecho probatório. Buenos Aires: Ejea, 1978.

SANTOS, Ernane Fidélis dos. Sistema probatório do processo civil brasileiro. Revista Forense, Rio de Janeiro, v. 97, n. 355, p. 51-59, maio/jun. 2001.

SANTOS, Moacyr Amaral. Comentários do Código de Processo Civil. 6. ed. Rio de Janeiro: Forense, 1994. v. 4.

. Primeiras linhas de direito processual civil. 20. ed. rev. São Paulo: Saraiva, 1999.

v. 2.

. Prova judiciária no cível e comercial. 4. ed. São Paulo: Max Limonad, 1970.

SATTA, Salvatore. Commentario al Codice di Procedura Civile. Ristampa da ed. de 1959. Milano: F. Vallardi, 1966.

SCHREIBER, Anderson. A proibição do comportamento contraditório: tutela da confiança e venire contra factum proprium. 2. ed. Rio de Janeiro: Renovar, 2007.

SILVA, Bruno Freire e. Inversão judicial do ônus da prova no CDC. In: CARVALHO, Fabiano; BARIONI, Rodrigo. Aspectos processuais do Código de Defesa do Consumidor. São Paulo: Ed. Revista dos Tribunais, 2008.

SILVA, De Plácido e. Vocabulário jurídico. Atualizadores: Nagib Slaibi Filho e Gláucia Carvalho. Rio de Janeiro: Forense, 2007. 
SILVA FILHO, Artur Marques da. Juizes irresponsaveis?: Uma indagacao sempre presente. Revista dos Tribunais, Sao Paulo, v. 80, n. 674, p. 70-80, dez. 1991.

SOARES, Fernando Luso. A responsabilidade processual civil. Coimbra: Almedina, 1987.

SOUSA, Miguel Teixeira de. Estudos sobre o novo processo civil. 2. ed. Lisboa: Lex, 1997.

STOCO, Rui. Abuso do direito e má-fé processual. São Paulo: Ed. Revista dos Tribunais, 2002.

SURGIK, Aloísio. Lineamentos do processo civil romano. Curitiba: Livro é Cultura, 1990.

TABOSA, Fabio Guidi. In: MARCATO, Antonio Carlos (Coord.). Código de Processo Civil interpretado. 3. ed. São Paulo: Atlas, 2008.

TALAMINI, Eduardo. Tutela relativa aos deveres de fazer e de não fazer. São Paulo: Ed. Revista dos Tribunais, 2001.

TARUFFO, Michele. Elementi per una definizione di "abuso del processo". In: L'ABUSO del diritto. Padova: Cedam, 1997. (Diritto privado, v. 3).

. General report. In: TARUFFO, Michele (Ed.). Abuse of procedural rights: comparative standards of procedural fairness. Haia; Londres; Boston: Kluwer Law International, 1999.

. Poderes probatórios de las partes y del juez en Europa. Revista Iberoamericana de Derecho Procesual, Buenos Aires, n. 10, 2007.

. La prova dei fatti giuridici: nozione generali. Milano: Giuffrè, 1992.

Studi sulla rilevanza della prova. Padova: Cedam, 1970.

THEODODO JÚNIOR, Humberto. Abuso do direito processual no ordenamento jurídico brasileiro. In: BARBOSA MOREIRA, José Carlos (Coord.). Abuso dos direitos processuais. Rio de Janeiro: Forense, 2000.

Comentários ao novo Código Civil: dos defeitos do negócio jurídico ao final do

livro III. Rio de Janeiro: Forense, 2003. v. 3, t. 2.

. Curso de direito processual civil. 39. ed. Rio de Janeiro: Forense, 2003. v. 1.

Direitos do consumidor. 4. ed. Rio de Janeiro: Forense, 2004.

VENOSA, Silvio de Salvo. Código Civil interpretado.São Paulo: Atlas, 2010.

VERDE, Giovanni. L'onere dela prova nel processo civile. Napoli: Jovene, 1974. 
VINCENZI, Brunela Vieria de. A boa-fé no processo civil. São Paulo: Atlas, 2003.

WAMBIER, Luiz Rodrigues. A responsabilidade civil do Estado decorrente dos atos jurisdicionais. Revista dos Tribunais, Sao Paulo, v. 77, n. 633, p. 34-42, jul. 1988.

WAMBIER, Teresa Arruda Alvim. Existe a 'discricionariedade' judicial? Revista de Processo. Sao Paulo, v. 18, n. 70, p. 232-234, abr./jun. 1993.

Noções gerais sobre o processo no Código do Consumidor. Revista de Direito do Consumidor, São Paulo, n. 10, p. 248-257, 1995.

Reflexões sobre o ônus da prova. Revista de Processo. Sao Paulo, v. 19, n. 76, p.141-145, out./dez. 1994.

YARSHELL, Flávio Luiz. Antecipação da prova sem o requisito da urgência e direito autônomo à prova. São Paulo: Malheiros Ed., 2009.

Responsabilidade civil do juiz por erro judicial: uma proposta equivocada. Carta Forense, São Paulo, maio 2012. 